
THE UNIVERSITY

OF ILLINOIS

LIBRARY

385

L976a

penty 
Return this book on or before the Latest Date stamped below. A charge is made on all overdue books.

University of Illinois Library

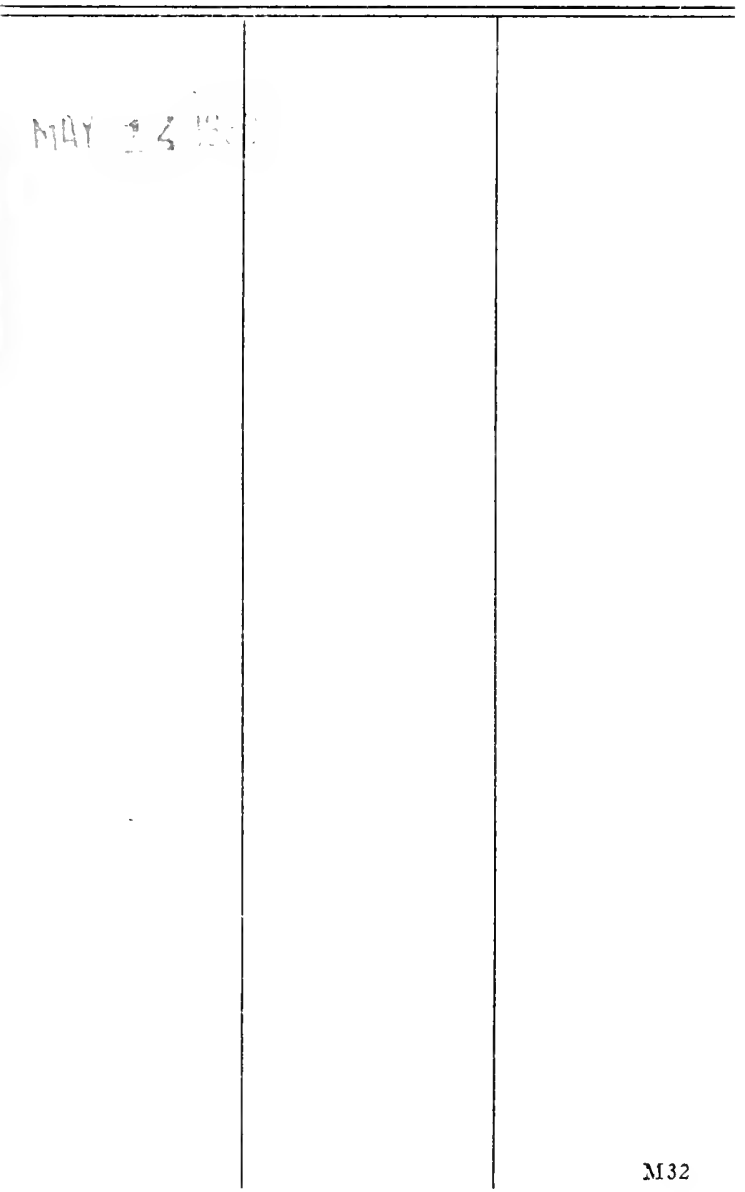






\section{INTERSTATE COMMERCE \\ AND \\ RAILWAY TRAFFIC COURSE}

Prepared under Editorial Supervision of

Samuel MacClintock, Ph. D.

The subjects listed below constitute the basic material of a course in Interstate Commerce and Railway Traffic. This course is especially designed to meet the constantly growing demand for efficiently trained men in railroad and industrial traffic work; to assist students to pass the examinations for government service under the Interstate Commerce Commission; and to meet the demand for men competent to direct the work of commercial organizations and traffic bureaus. With the exception of the Atlas of Railway Traffic Maps, the subjects listed below are covered in an average of approximately 200 pages each.

Atlas of Railway Traffic Maps

Freight Classification; Some Ways of Reducing Freight Charges

Freight Rates: Official Classification Territory and Eastern Canada; Bases for Freight Charges

Freight Rates: Southern Territory; The Industrial Traffic Department

Freight Rates: Western Territory

Publication and Filing of Tariffs

The Bill of Lading; Routing Freight Shipments; Freight Claims

Railway Organization; Statistics of Freight Traffic; Railway Accounting

Express and Parcel Post

Ocean Traffic and Trade

Government Control of Common Carriers

Interpretation of the Act to Regulate Commerce

Rulings of the Interstate Commerce Commission and Procedure before that body

Business Law, I

Business Law, II

The Law of Carriers of Goods

Practical Traffic Problems

LASALLE EXTENSION UNIVERSITY 


\title{
THE ACT TO REGULATE COMMERCE AND SUPPLEMENTAL ACTS
}

\author{
HERBERT C. LUST \\ Of the Chicago Bar \\ Co-Author, "Digest of Decisions \\ Under the Interstate Commerce Act"
}

\section{La SAILE Xitension Univepsity}

(Home Study Under Expert Guidance)

CHICACO 


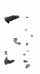

3

$\because ?$

Copyright, 1915

LaSalle Extension Univergity 


\section{CONTENTS}

\section{SECTION 1}

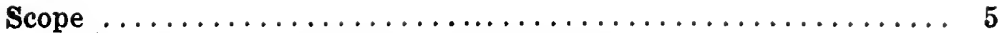

Pipe lines.............................. 7

Common control, management, or arrangement............ 9

Adjacent foreign country ....................... 13

Intrastate commerce.......................... 13

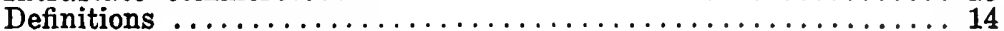

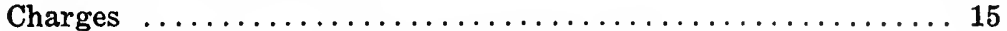

Jurisdiction of Commission over classification........... 22

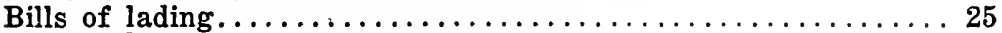

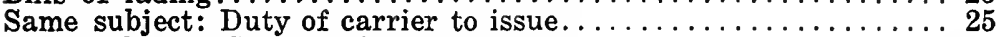

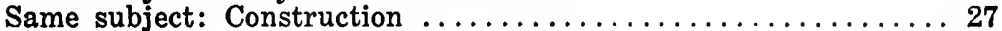

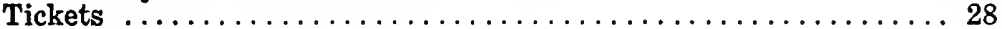

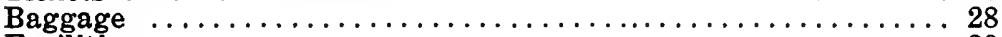

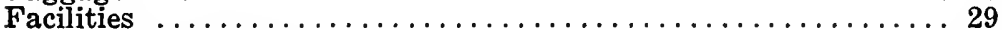

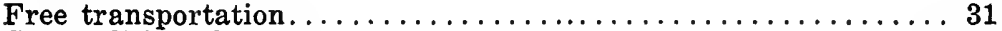

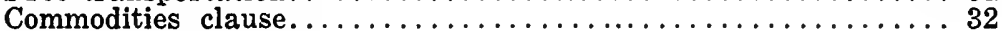

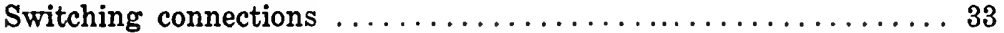

\section{SECTION 2}

Crimes

\section{SECTION 3}

\section{DISCRIMINATION}

In general. . . . . . . . . . . . . . . . . . . . . . . . . 39

Control and regulation of discrimination. . . . . . . . . . 43

Jurisdiction of Commission....................... 43

Determination of discrimination................. 44

Justification of discrimination: Carrier as shipper or consignee. . 4 48

Same subject: Carrier not serving prejudiced point. . . . . .... 48

Same subject: Competition in general.................49

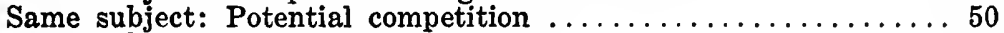

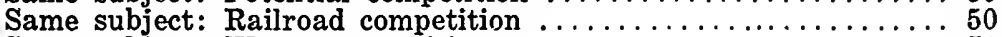

Same subject: Water competition $\ldots \ldots \ldots \ldots \ldots \ldots \ldots \ldots \ldots \ldots \ldots \ldots$

Removal of discrimination.................... 53

\section{FACILITIES}

Interchange of facilities..................... 54

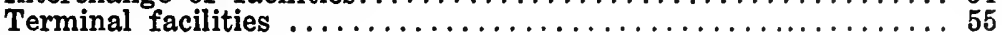

\section{SECTION 4}

\section{LONG-AND-SHORT-HAUL RULE}

In general 56

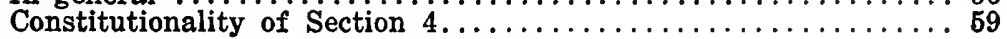


Jurisdiction of Commission. ..................60

Exceptions .................................60

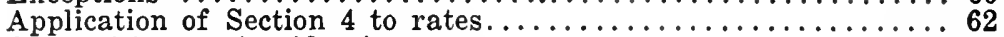

Competition as justification....................... 62

\section{SECTION 5}

Pooling of freight......................... 65

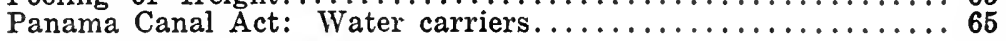

\section{SECTION 6}

1. TARIFFS

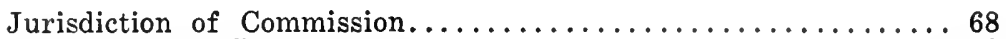

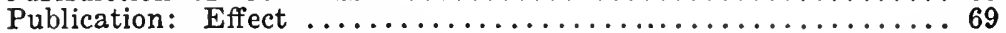

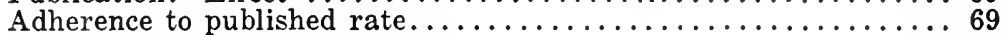

Erroneous quotation by carrier.................... 70

Necessity of publication........................ 71

Purpose of publication......................... 71

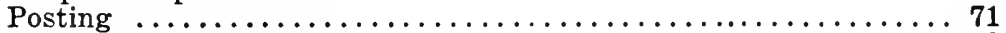

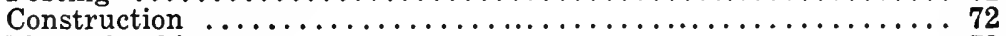

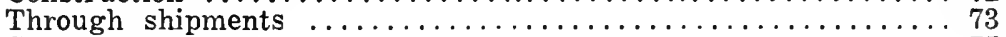

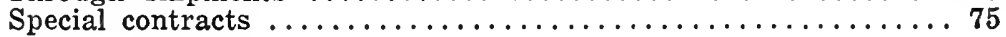

\section{SECTION 7}

Continuous carriage $\ldots \ldots \ldots \ldots \ldots \ldots \ldots \ldots \ldots \ldots \ldots \ldots$

SECTION 8

Attorney's fees $\ldots \ldots \ldots \ldots \ldots \ldots \ldots \ldots \ldots \ldots \ldots \ldots \ldots . \ldots \ldots$

SECTION 9

Actions at law. .............................. 81

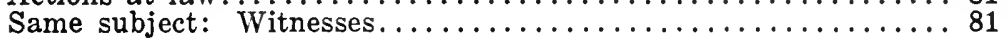

SECTION 10

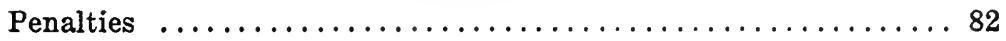

SECTION 11

The Interstate Commerce Commission. . . . . . . . . . . . . 85

SECTION 12

Powers of Commission...................... 86

SECTION 13

Parties to complaints. 
SECTION 14

Reports of the Commission....................... 89

\section{SECTION 15}

Importance of Section $15, \ldots \ldots \ldots \ldots \ldots \ldots \ldots \ldots \ldots \ldots, 90$

\section{JURISDICTION OF COMMISSION}

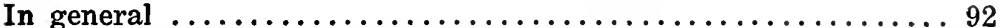

Primary jurisdiction $\ldots \ldots \ldots \ldots \ldots \ldots \ldots \ldots \ldots \ldots \ldots, \ldots \ldots, 92$

Finality of Commission's findings.......................... 94

Jurisdiction over procedure.......................... 96

Jurisdiction over orders............................. 96

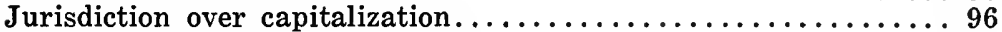

Jurisdiction over interstate rates.......................... 97

Jurisdiction over intrastate rates........................ 98

Jurisdiction over suspension of rates................... 99

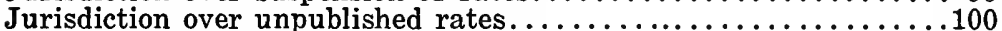

Jurisdiction to award damages..........................100

Jurisdiction over reasonable rates.......................101

Jurisdiction over divisions ..............................102

Jurisdiction over advanced rates: In general.................103

Same subject: Justification of increase..................105

Same subject: Right to advance rates....................106

Same subject: Right to earn...........................107

Same subject: Change in conditions.....................

Jurisdiction over through routes and joint rates...............112

Same subject: Establishment by carrier...................115

Same subject: Right to favor own line.....................116

Same subject: What is satisfactory through route.............118

Same subject: Right to withdraw through routes...............118

Same subject: Obligation to furnish equipment..............119

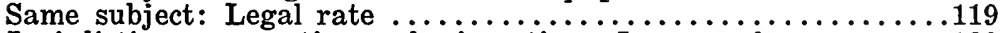

Jurisdiction over routing and misrouting: In general............120

Same subject: Carriers' duty to transport.................120

Same subject: Accustomed or natural route................121

Same subject: Cheapest available route...................121

Same subject: Conflict in billing between rate and route........121

Same subject: Shipper's instructions ....................122

Same subject: Liability for misrouting.........................

Jurisdiction over electric lines..................................

Jurisdiction over business secrets.......................125

Jurisdiction over water carriers: Discrimination and rebates.....126

Jurisdiction over allowances: In general..................... 128

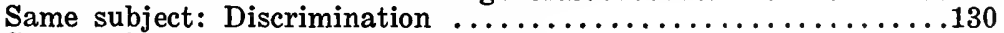

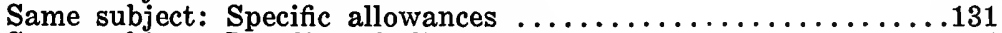

Same subject: Legality of allowances............................

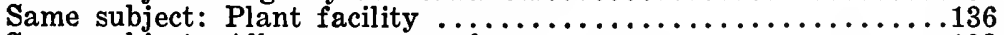

Same subject: Allowances as rebates......................138

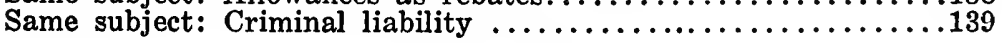

\section{SECTION 16}

1. REPARATION

Jurisdiction of Commission. ..........................140

Necessity of primary action by Commission.................... 
Necessity and effect of finding of unreasonableness . . . . . . . . . 142

Power to award tort damage..........................

Right to recover and necessity of protest............... 147

Necessity of first paying tariff rate..................

Parties entitled to recover......................... 148

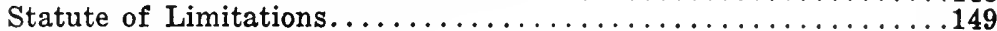

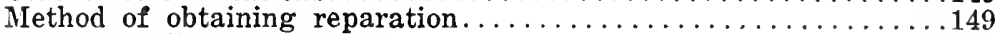

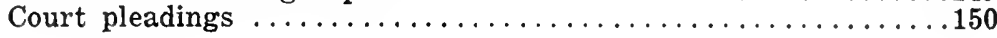

\section{SECTION 16a}

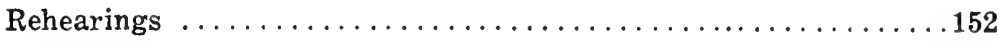

\section{SECTION 17}

1. PROCEDURE

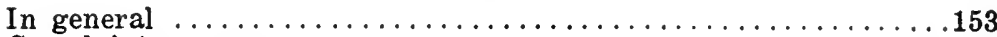

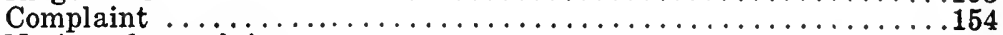

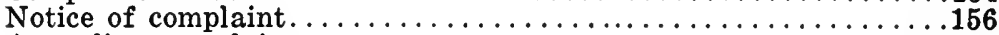

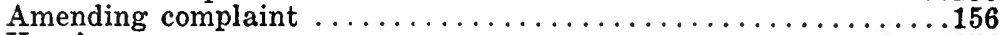

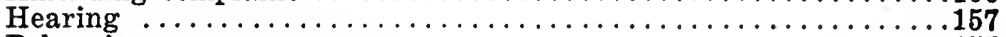

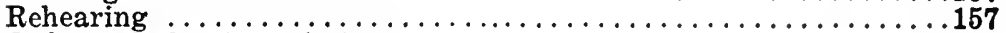

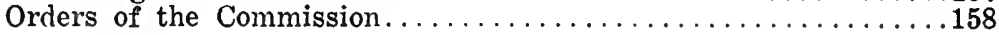

\section{SECTION 18}

Salaries of Commission.

SECTION 19

Office of the Commission. .160

\section{SECTION 20}

2. REPORTS

2. THE CARMACK AMENDMENT

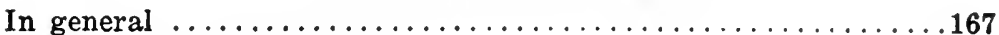

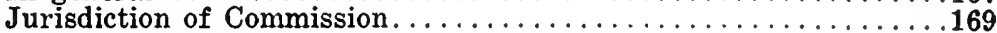

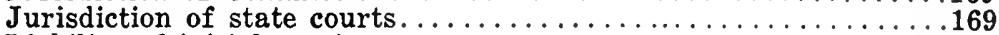

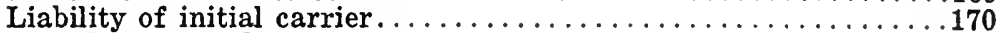

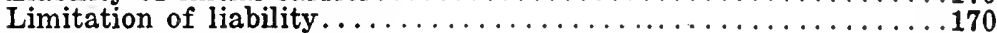

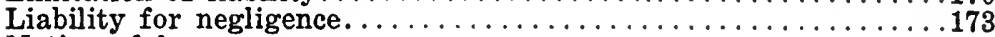

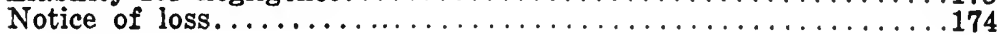

SECTION 21

Report by Commission....................

\section{SECTION 22}

1. REDUCED RATES

Charitable institutions $\ldots \ldots \ldots \ldots \ldots \ldots \ldots \ldots \ldots \ldots \ldots$

Returned shipments ............................. 
SECTION 23

Jurisdiction of United States courts...................181

SECTION 24

The Interstate Commerce Commission..................181

MISCELLANEOUS ACTS

District Court Jurisdiction Act.......................182

Compulsory Testimony Act......................................

Elkins Act $\ldots \ldots \ldots \ldots \ldots \ldots \ldots \ldots \ldots \ldots \ldots \ldots \ldots \ldots \ldots \ldots \ldots \ldots, 184$

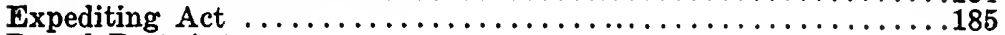

Parcel Post Act...................................185

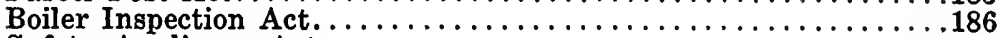

Safety Appliance Act.................................187

Block Signal Act.................................187

Monthly Reports of Accidents Act.............................

Hours of Service Act...............................188

Transportation of Explosives Act.....................189 



\section{INTRODUCTION}

It may be stated that almost from the time there was a railroad in the United States regulation has been necessary. The first railroad in the United States was the Quincy Railroad, built in 1826; then in 1827 the Mauch Chunk, 9 miles long and costing $\$ 27,000$, was constructed in 63 days. The Baltimore \& Ohio, 15 miles long and using horse power, was built in 1830. The Mohawk \& Hudson was built in 1831 and was the first to use the locomotive. In 1835 there were in the whole United States 918 miles of railroad.

Now it is a curious thing that on June 14, 1839, the first state board of railroad commissioners was appointed by an act passed by the general assembly of Rhode Island. Section 2 provided that it should be the duty of the board of commissioners upon complaint or otherwise, whenever a majority of them should deem it expedient, personally to examine into any or all of the transactions or proceedings of any railroad that might be established in the state. Two objects were to be gained from such investigations: (1) to secure full and equal privileges for the transportation of persons and property in proportion to the distances any such persons or property might be transported on any railroad; (2) to inquire into any contract or agreement by which any railroad company should attempt to transfer or give to any steamboat company favors or preferences over any such company or boat, whether as to freight or passengers, contrary to the intent and meaning of the Act.

We see, therefore, that only thirteen years after the first railroad was built it was considered necessary to 
regulate the carriers. Other states followed, and as lines were built it was found necessary to control them. Thus, between 1839 and 1887 the following states created railroad commissions, in the order named: Rhode Island, Vermont, New Hampshire, Connecticut, New York, Maine, Tennessee, Ohio, Massachusetts, Minnesota, Illinois, Michigan, Georgia, Virginia, Wisconsin, Missouri, California, Iowa, South Carolina, Kentucky, Alabama, and Kansas.

In 1887 the Interstate Commerce Commission was created to regulate such traffic moving between the various states as was not regulated by the state commissions. The authority under which the Interstate Commerce Commission was created and given its powers was known as the Interstate Commerce Act.

The original act created a commission of five members and gave it certain power's over railroads. The courts soon held that the Commission had not been given the rate-making power and it became evident that further legislation was necessary if the Commission was ever to benefit the public as was intended. In 1903 the Elkins law was passed, which provided drastic punishment for the giving of rebates or concessions from the rates. In 1906 an act was passed giving the Commission the right to fix maximum rates for the future, which, together with the power to suspend advances in rates given by the law of 1910, has given to the Commission the power to enforce one of the most elaborate systems of governmental regulation ever devised. Its power is broad and is practically unlimited for the elimination of unreasonable charges and unjust discrimination.

In the United States today there are approximately 260,000 miles of railroad, employing millions of men and representing an investment of billions of dollars. The magnitude of this business is so great that it cannot be 
grasped by the average mind. The quick interchange of commodities is so dependent upon the railroad and so much a part of the business of every industrial establishment that the importance of the transportation question cannot be overestimated. The Interstate Commerce Act has become the most magnificent instance of regulation of great public utilities that modern civilization has been able to develop. It is, therefore, of the utmost importance that one should be thoroughly acquainted with its various provisions. He should know it by heart and he should know in detail the construction which has been given it. It is a regrettable thing to say that in the past the traffic man has to a great extent neglected to familiarize himself with the Interstate Commerce Act.

Up to very recently there had been no analysis made of the principles governing traffic. This, coupled with the fact that the Act itself was very long and intricate, proved too much for any except the most ambitious. It is now shown that there are something like 15,000 principles governing the movement of interstate traffic and these have been classified and analyzed so as to be easily accessible. In the following pages they have been so condensed and simplified that whoever will take the trouble carefully and conscientiously to study the subject as therein discussed will receive an education that will enable him to apply the Act with a good degree of understanding.

In this treatise the Act has been discussed section by section, as this seems to be the most satisfactory method. It will be found that in some cases the same subject is treated in more than one section for the reason that in amending the original Act to Regulate Commerce from time to time, the amendments were not always made to the existing sections, but were made by putting in additional sections. For example, we find that Section 11 
provides that the Commission shall consist of five members; in Section 24, added June 29, 1906, it is provided that the Commission shall consist of seven members.

In treating each section, reference is made to other sections that bear upon the same subject. It must be borne in mind that in a short treatise like this it is not possible to treat all the points that might be considered in the study of so large a subject as the Interstate Commerce Act. It has been the endeavor of the author to set out briefly and clearly only the important principles. 


\section{SECTION 1}

Scope.-The first section is one of the most important, since it is the one which defines the application of the statute. For the exact language it will be necessary for the reader to refer to the back of this book, where the Act itself will be found.

The Act applies to any corporation or person engaged in the transportation of oil or other commodity (except water and natural and artificial gas) by means of pipe lines exclusively or in conjunction with railroads or other carriers; to telegraph, telephone, and cable companies, whether wire or wireless; and to any common carrier engaged in the transportation of persons or property wholly by railroad or in conjunction with water carriers when both are used under a common control, management, or arrangement for a continuous carriage or shipment from one state or territory of the United States or the District of Columbia, to any other state or territory, or to the District of Columbia, or from one place in a territory to another place in the same territory, or from one place in the United States to an adjacent foreign country, or from any place in the United States through a foreign country to any other place in the United States. It also applies to the transportation of property shipped from any place in the United States to a foreign country and carried from such place to a port of transshipment, or shipped from a foreign country to any place in the United States, and carried to such place from a port of entry either in the United States or in an adjacent foreign country. 
It should be borne in mind that the Act applies to interstate commerce or to foreign commerce only to the extent provided for.

While the provisions of Section 1 just given specify the classes of transportation agencies that are subject to the Act, it may be well to note the most common individual agencies that are subject to the Act. Among these are the following: railroads, express companies; pipe lines, sleeping-car companies, telegraph companies, wireless companies, cable companies, electric railroad companies, refrigerator lines, and water carriers when operating in connection with rail carriers in the handling of interstate traffic.

It will be noted that water carriers are subject to the Act only in connection with rail carriers. It may be helpful in getting a full understanding of this provision to illustrate when a water carrier would and when it would not be subject to the Act. A shipment moving from New York to New Orleans by a boat line is not subject to the Act, but if the shipment moves from Pittsburgh to New York by rail, and from New York to New Orleans by water, on a through bill of lading from Pittsburgh to New Orleans, it is subject to the Act. This is because in the latter case the boat line is used in conjunction with a rail carrier under a common arrangement in moving an interstate shipment.

The Ast provides that it does not govern the movement of shipments when entirely within a state. However, it must be borne in mind that if the shipment, in moving from one point in a state to another point in the same state, passes out of that state at any point, the traffic becomes interstate and is hence subject to the interstate commerce law. As an example, suppose a shipment were moving from New York City to Albany, N. Y. If this shipment moved from New York City to Weehawken, N. J., 
for transportation via the West Shore Railroad, the shipment would be interstate within the meaning of the Act and therefore subject to tariff filed with the Interstate Commerce Commission. However, if the shipment moved from New York City to Albany via the New York Central \& Hudson River Railroad, it would not pass out of the state of New York and consequently would not be subject to interstate tariffs, but would be intrastate within the meaning of the word as used in the Act. It will often be found that shipments moving between the same points within a state may be interstate or intrastate according to the route used. It is quite common to find that shipments may move over one road and be intrastate because the road is entirely within that state, while it may be interstate over another road because the second road passes out of the state en route. It is quite often necessary, therefore, to know the exact route used in the movement of a shipment in order to ascertain whether it is interstate or intrastate.

On page 14 will be found definitions of some of the terms used in connection with the last part of Section 1. For example, we find that the term "transportation" does not mean simply the moving of freight from one point to another, as might be supposed, but that it specifies a number of things beyond what is generally considered as being included in the term "transportation" as used in the Act.

Pipe lines.-The Interstate Commerce Act has placed pipe lines under the authority of the Interstate Commerce Commission. The Commission has investigated the relations between the pipe lines and has decided that they are common carriers and must transport oil for all along their lines without discrimination, and, like other carriers, must file tariffs of their rates. 
Prior to the Hepburn Amendment of 1906, the pipe-line companies had never been so considered. They have never held themselves out to the world as such, but have made it their business to buy oil at the producing well, transport it by means of their own pipe lines across state boundaries, and sell it in other states. They claimed to be dealers in oil who use their own pipe lines solely to convey their own property from state to state. For instance, oil from Oklahoma points was transported by the Oklahoma Pipe Line Company for the Prairie Oil and Gas Company to McCurtin on the Oklahoma-Kansas state line. There it was to be delivered to the Prairie Oil and Gas Company, which transported it by its own line across the southwestern corner of Arkansas to Ida, La., where delivery was said to be made to the Standard Oil Company of Louisiana. This company transported the oil to its refinery at Baton Rouge, La., where it was refined. When it left Oklahoma, the oil was destined for storage in Louisiana. The pipe-line companies contended there was a breakage of transit at each state line and that the transportation was not interstate and therefore not subject to the jurisdiction of the Commission. The Commission held that the stoppage in transit was not made in good faith and that the intention of Congress was to make all interstate pipe lines common carriers, and ordered them to file with the Commission schedules of their rates and charges for the transportation of oil.

This case was appealed to the Supreme Court of the United States. There it was held that, although prior to the passage of the Hepburn Act, pipe lines might have been private carriers, it was proposed in that act to provide that if they desire to continue in business, they must be common carriers. Hence, at the present time a pipe line stands on the same footing as a railroad. It must publish and file its tariffs with the Interstate 
Commerce Commission, designating its rates for the transportation of oil. It must receive oil from whomever tenders it and carry it to destination. It cannot discriminate in rates between shippers, give rebates, charge a higher rate to a farther distant point, or give facilities to one and deny them to another similarly situated. It is in all respects subject to the same limitations and restrictions as a railroad.

Common control, management, or arrangement.-One of the provisions of the Act which has occasioned a considerable amount of discussion has been that part of Section 1 referring to water carriers. It should not be understood, however, that Congress has not authority over interstate transportation by water, because it does have power to pass such legislation if it is necessary to do so; but in the Interstate Commerce Act it did not see fit to exercise its admitted authority. The main purpose of the Act is to regulate transportation by railroad. The regulation of water lines was considered incidental and collateral and was included in order that the regulation of railroads might be effective and not subverted by an arrangement between railroads and water lines. Carriers of interstate commerce by water, therefore, are subject to the Act only in respect to traffic transported under a common control, management, or arrangement with a rail carrier. By the amendment of 1912, the Commission is given power to couple up interstate water and rail carriers and order in through routes and joint rates between such carriers, if necessary.

It may be interesting to note the reason which underlies this exemption. As has been seen from a study of the introduction to this treatise, the development of commerce has created the necessity of regulating rail carriers. The only carriers competing with the railroads are 
those that operate on water. It has, therefore, been the aim of the railroads to dominate their rival water carriers. Competition by water is the most potent method of reducing rail rates, and it was therefore deemed wise to leave this competition as a check on the rail carriers.

Another reason for not restricting the water carriers comes up in the case of foreign commerce. The ocean is a highway, free to all. No franchise is needed to sail the seas, nor is the ownership of a line of ships founded either in law or in economics upon the theory of a monopoly which underlies the relation of the railroad to the state.

The phrase "common arrangement" means an agreement or understanding between connecting carriers with respect to the transportation of merchandise and the charges and divisions to be made therefor.

Some typical cases are as follows: A steamship company operated on the Great Lakes from Buffalo, New York, to West Superior, Wisconsin. It contracted with a shipper to protect $^{1}$ a rate of 45 cents on iron from Emans, Pennsylvania, to Winnipeg, Manitoba. The rate published by the initial and delivering rail carriers was $491 / 2$ cents. The steamship company did not concur in this rate. 'The railroads were not informed of the agreement between the shipper and the steamship company for the 45-cent rate, and the bills of lading, shipping receipts, and other documents called for a rate of $491 / 2$ cents, and specified the divisions that the initial and delivering carriers were to receive. This rate was collected. The steamship company rebated the difference between the $491 / 2$-cent rate and the 45 -cent rate. No further proof was shown of any other undertaking or arrangement between the rail carriers and the water carriers. It was

'The term "protect" as here used means that the boat lines promised that the rate would not be higher than 45 cents. 
held that the steamship company carrying wholly by water was not shown to have entered into a "common arrangement" with the rail carriers so as to make it subject to the Interstate Commerce Act, and could not be convicted of rebating under the Elkins Act, and that the mere agreement by an independent water carrier to accept freight from a connecting railroad and to transport it for its own particular rate may be an "arrangement" for continuous carriage, but it is not a "common arrangement" within the meaning of the Act. ${ }^{2}$

Broadly speaking, the Act does not apply to carriers by water. To make such carriers subject to the Act it must be shown that transportation partly by railroad and partly by water is made under a common control, management, or arrangement for a continuous carriage or shipment from one state or territory to another state or territory. ${ }^{3}$

Where steamship companies operating on the Great Lakes file with the Interstate Commerce Commission their joint tariffs, or their concurrence in tariffs filed by the railroad companies, and carry for hire passengers and freight under such joint tariffs over the water portion of the through routes, there is engagement in transportation in so far as both water and rail are used to carry from one state to another, and there is within the meaning of the Act.as amended June 29, 1906, a common arrangement made for a continuous shipment of passengers and freight, whereby such companies have brought themselves within the terms of the Act and are subject to such of its provisions as are applicable to carriers under such arrangement. ${ }^{4}$

'Mutual Transit Co. v. U. S., 178 Fed. 664.

'Mutual Transit Co. v. U. S., 178 Fed. 664.

'Goodrich Transit Co. v. I. C. C., 190 Fed. 943, 959. 
An order of the Interstate Commerce Commission required statistical information of certain water carriers as to the routes of the carriers and their mileage; the amount of traffic, both passenger and freight; mileage and revenue statistics, together with a separation of freights into the quantity of the various products transported, showing whether originating on the carrier's line or received from a connecting line; and a general description of any separate business carried on by the carrier. It was held that the Commission did not exceed its authority as to the form of the reports and the system of accounting described and that the Commission could require such reports to include statistics relating to port-toport state traffic. ${ }^{5}$

Three carloads of potatoes, loaded in "heater" cars at different stations on the line of the Bangor Railway \& Electric Company, an electric railway, for shipment via Bangor, Maine, and the Maine Central Railroad, to Hoboken, New Jersey, were damaged by freezing in transit. Though the shippers intended a through shipment to Hoboken, the Bangor Railway \& Electric Company issued bills of lading only over its own line, but there was a through tariff rate from points of shipment to destination, and the Maine Central Railroad, in receiving the cars at Bangor, advanced to the Bangor Railway \& Electric Company its proportion of the through freight charges. It was held that the latter fact is some evidence of a "common control, management, or arrangement for a continuous carriage or shipment," as defined by Section 1 of the Interstate Commerce Act, and that therefore the Bangor Railway \& Electric Company was as to such shipments originally within the scope of the Act as amended by the Carmack Amendment and as

'I. C. C. v. Goodrich Co., 224 U. S. 194, 211. 
initial carrier was liable for the defaults of connecting carriers. ${ }^{\mathbf{c}}$

The publication of proportional rates by rail carriers and a lake steamship company covering through interstate transportation, the actual movement of traffic upon through bills of lading, and the prepayment of freight charges, necessitating an accounting between the carriers, constitute evidence of a common arrangement for a continuous carriage. ${ }^{7}$

Adjacent foreign country.-The word "adjacent" as used in the Act to modify the words "foreign country" means a country adjacent in the sense of there being substantial continuity of rails. Thus, Cuba is not an "adjacent foreign country" within the meaning of the Act. Canada and Mexico are "adjacent foreign countries" as specified in the Act.

While the discretion of the Commission in the enforcement of the Act cannot be interfered with by mandamus, yet an action may be taken to compel the Commission to take jurisdiction over carriers operating between Alaska and the United States and between Alaska and adjacent foreign countries, where the Commission has refused to do so pursuant to its belief that it had no authority over such carriers. ${ }^{8}$

Intrastate commerce.-While the power of Congress to regulate the field of interstate commerce is supreme, it may fail to exercise such power and the state may have power to act. In other words, simply because the Interstate Commerce Act exists, it does not follow that Congress has so occupied the field of interstate commerce as to preclude any action whatever by the states. But where Congress or the Interstate Commerce Commission

'Ross v. M. C. R. R. Co. (Me., 1914), 90 Atl. 711.

'Flour City S. S. Co. v. L. V. R. R. Co., 24 I. C. C. 179.

'I. C. C. v. H. S. Co., 224 U. S. 474. 
has passed a regulation covering a specific subject, the state can no longer legislate concerning it. Of course, traffic which is purely intrastate, that is, which originates within the boundary of a state and is destined to a point in the same state and in transit does not pass outside, is subject only to legislation by the state. Neither Congress nor the Interstate Commerce Commission has any power to legislate concerning it, although, as we have seen, the states may sometimes pass laws that affect interstate traffic. Thus, we have laws that trains shall not sell cigarettes or liquors within the boundaries of certain states, that locomotives must be equipped with a certain kind of headlight, that passenger fares shall not exceed 2 cents a mile, etc. It very often happens that a certain regulation, such as one to use a certain kind of headlight, may be forced upon the carrier in one state, while a neighboring state declares its use illegal. These state laws, of course, are burdensome to the carrier.

The Supreme Court, however, recently held, in what is known as the Shreveport case, that when a system of state rates is of such a character that to reduce them would of necessity mean the reduction of interstate rates, the state authorities had no power to take such action. In other words, where state rates were so low as to discriminate against reasonable interstate rates, the state rates had to give way.

Just what effect this decision is going to have in the future it is hard to determine. Its logical effect would seem to be that whenever a state rate is so tied up with an interstate rate that the state rate cannot be changed without affecting the interstate rate, such change cannot be made without the consent of the Interstate Commerce Commission.

Definitions.-In stating to what facilities, privileges, and instrumentalities the Act applies, certain definitions 
are made. The reader, however, is cautioned to remember that the Act has been construed to cover facilities and privileges not specifically enumerated. As a matter of fact, every instrumentality, facility, or privilege connected with interstate commerce is subject to the Act. The term "railroad" is defined to include all bridges and ferries used in connection with any railroad, all the road used by any railroad, whether owned or operated under a lease or other contract, and all switches, spurs, tracks, and terminal facilities of every kind used or necessary in transportation, including freight depots, yards, and houses. The term "transportation" includes cars and other vehicles, and all instrumentalities and facilities of shipment or carriage, irrespective of ownership or of any contract for the use therefor. It includes all service in connection with the receipt, delivery, elevation, and transfer in transit, valuation, refrigeration, icing, storage, and handling of property transported. It further provides that it is the duty of every carrier subject to the Act to provide transportation upon reasonable request therefor, to establish through routes and reasonable rates applicable thereto, and to provide reasonable facilities for operating through routes and with respect to the ex-. change and interchange of cars.

Charges.-It is provided that all charges for any services rendered in the transportation of passengers or property or for the transmission of messages by telegram or telephone or cable, or in connection therewith, shall be just and reasonable, and every unjust and unreasonable charge for such service is prohibited. The question as to what is a just and reasonable rate is the most difficult one raised by any section of the Act.

As will be seen by the discussion under the powers of the Commission, in the determination of a reasonable rate there are dozens of elements that must be consid- 
ered. The duty of initiating rates rests with the carrier. If, however, the carrier does not establish a reasonable rate, the authority of the Commission can be invoked to determine the justness of the rate. However, under Section 15 , the carrier is entitled to have a finding by the Commission that any particular charge is unreasonable and unjust before it is required to change such charge. ${ }^{9}$

The question of what is a reasonable rate presents the most difficult question to determine. A railroad is entitled to such a schedule of rates as will permit it to earn a fair return upon the capital invested. Perhaps the best discussion in this matter is found in the following case.

In Coal \& Coke Ry. Co. v. Conley, ${ }^{10}$ the court said:

"What constitutes a fair and reasonable return for the use of invested capital has never been definitely settled by the adoption of any particular standard for all purposes and to govern under all conditions. It seems to be difficult, if not impossible, to lay down any rule or principle that will operate equitably and justly under all circumstances. Ordinarily, the return generally realized upon similar investments in the locality of the one under consideration is deemed fair and guaranteed to the investor, and the estimate is based upon the amount actually invested in good faith, fictitious valuations, indicated by overissues of stocks and bonds, and not representing actual money, being rejected.'"11

The mere fact that a corporation has outstanding bonds and stocks in large amounts, on which holders claim interest and dividends, is by no means conclusive

${ }^{9}$ I. C. C. v. Stickney, 215 U. S. 98.

${ }^{10}$ W. Va. (March 8, 1910), 67 S. E. 613, p. 639.

${ }^{12}$ Smyth v. Ames, 169 U.' S. 466,$544 ; 18$ Sup. Ct. $418 ; 42$ L. Ed. 819; Covington, etc., Co. v. Sandford, 164 U. S. 578; 17 Sup. Ct. 198; 41 L. Ed. 560; Dow v. Beidelman, 125 U. S. 680 ; 8 Sup. Ct. 1028; 31 L. Ed. 841; Stanislaus County v. Canal \& Irrigation Co., 192 U. S. 201; 24 Sup. Ct. 241; 48 L. Ed. 406; Spring Valley Water Works v. Schottler, 110 U. S. 347 ; 4 Sup. Ct. 48; 28 L. Ed. 173; Railroad Com. Cases, 116 U. S. 307 ; 6 Sup. Ct. 334, 338, 1191; 29 L. Ed. 636. 
of the value of the property or the amount actually invested. Exorbitant rates cannot be exacted from the public for the sole reason that persons interested in a corporation have contracted with it and with one another for profits in excess of that which amounts to a reasonable and fair return on the money actually invested or the equivalent of the actual value of the plant. The capitalization or actual cost may far exceed the utmost value of the company's property, for some reason. The plant may have been built at an extravagant and wasteful cost, or may not be well adapted to the uses for which it was intended. Under exceptional and peculiar circumstances, what would be ordinarily a reasonable rate of profit on the entire investment is disallowed, as being more than the service is worth to the public and therefore unjust to it. If, in construction or purchase, more money has been put into a plant than is required for one adequate to the demands of the community, the usual return on such sum would be more than the service rendered the public worth. Both the public and the public service investor are to be considered, and justice done to each. ${ }^{12}$

The result of these and other decisions is that almost every case must be dealt with in the light of its own peculiar facts and circumstances, it being impossible to lay down any rule for invariable application to all. In respect to the rate of compensation, there ought to be less uncertainty; but as to it, the circumstances of each case seem to have some bearing; and, besides, what is said on the subject is often somewhat confused with the discussion of the value. This is especially true of those cases in which the value of the service to the public is discussed.

${ }^{22}$ Smyth v. Ames, 169 U. S. 446, 18 Sup. Ct. 418, 42 L. Ed. 819; Covington, etc., Co. v. Sandford, 164 U. S. 578, 17 Sup. Ct. 198; 41 L. Ed. 560 ; San Diego, etc., Co. v. Jasper, 189 U. S. 439, 23 Sup. Ct. 571, 47 L. Ed. 892. 
In almost every case, it is possible to begin the discussion from the standpoint of either party, or to begin at each end and conclude in the middle. However, it seems to be generally held that in the absence of peculiar and extraordinary conditions, such as a more costly plant than the public service of the community requires, or the erection of a plant at an extravagant cost, or the purchase of one at an exorbitant or inflated price, the actual amount of money invested is to be taken as a basis. Upon this a return must be allowed equivalent to that which is ordinarily received in the locality in which the business is done, upon capital invested in similar enterprises. In addition to this, consideration must be given to the nature of the investment, a higher rate being regarded as justified by the risk incident to a hazardous investment. From this it is obvious that the courts have not, and cannot, establish any particular rate for all concerns, all classes of business, and all communities, as a limit upon the powers of the legislature to regulate it. To some extent, therefore, every case must stand upon its own circumstances in respect to the rate to be allowed as well as the valuation upon which it is to be calculated; but the rate is obviously affected in a lesser degree by peculiar circumstances than the valuation to which it is applicable. As we have said, the courts do not establish rates; the extent of their power is to nullify rates when found to be so low as to work confiscation of property or deprivation of the equal protection of the laws. ${ }^{13}$

In State v. N. P. Ry Co., ${ }^{14}$ the North Dakota Supreme Court said:

"Wilcox v. Gas Co., 212 U. S. 19; 29 Sup. Ct. 148; 53 L. Ed. 371, 382 ; Knoxville v. Water Co., 212 U. S. 1; Stanislaus County v. Water Co., 192 U. S. 201 ; 24 Sup. Ct. 241; 48 L. Ed. 406; Land Co. v. Jasper, 189 U. S. 439 ; 23 Sup. Ct. 571 ; 47 L. Ed. 892; Reagan v. Loan \& Trust Co., 154 U. S. 362 ; 14 Sup. Ct. 137 ; 38 L. Ed. 1014.

${ }^{11 N}$. D." (1909), 120 N. W. 869, affirmed 216 U. S. 579, p. 871. 
"For the purpose of showing the unreasonableness of rates fixed, will defendant be permitted to single out the one commodity to which the rates apply, and prove, as it has attempted to do in this case, that the transportation thereof is a losing proposition to the carrier; or must it not show that if such rates are enforced it will be unable from the total freight receipts to earn a sum above operating expenses sufficient to yield a fair and reasonable profit upon its investment, provided the road was economically and efficiently constructed and operated?"

Railroads are the private property of their owners and while from the public character of the work in which they are engaged the public has the power to prescribe rules for securing just and efficient service and equality between the shippers and communities, yet in no proper sense is the public a general manager. What is a reasonable freight rate cannot, strictly speaking, be the subject of agreement between carriers and shippers, or between carriers and the Interstate Commerce Commission. If in a given case, after weighing all feasible contentions by the parties, the Commission is clearly of the conviction that the rates in effect are wrong, it is its duty to substitute for those rates others which it believes to be right, but it is not required to interfere unless clearly of the conviction that the schedule in effect is unlawful. A just and reasonable rate must be one which respects alike the carriers' interests and the character of the traffic. The words "just and reasonable" imply the application of good faith and fairness, of common sense and a sense of justice in accordance with the given condition of facts. They are not fixed, unalterable terms. Their meaning implies the exercise of judgment.

In fixing a rate, however, the Commission must be conscious in its consideration of its effect upon the policy of 
the railroads and ultimately upon the welfare of the state. The country cannot afford to have poor railroads inefficiently equipped, unsubstantially built, and carelessly operated, but in the giving of service the railroad management should be the most progressive. It should have wide latitude for experiment. It should have such encouragement as would stimulate the imagination of both the engineer and investor. However, it must be borne in mind that the Government is not the railroad's manager and neither is the Commission, and no matter what the revenue the railroads may receive, there is no control upon its expenditure, no improvement directed, and no economy enforced. ${ }^{15}$

Freight rates cannot be made solely with reference to the value of the article transported or with reference to the loss and damage claims arising from transportation. The carrier is entitled to take into consideration the occupancy of its equipment and facilities, or, in other words, to charge for the service rendered. This charge for the service rendered may be based upon the rate per ton per mile, which is most helpful in connection with dense, heavy articles. The value of the service and the reasonableness of the rate may be tested by means of the rate per car per mile, where articles of the same relative weight, density, direction, and volume of movement are in question. But generally the ultimate test with the carrier itself must be the return for the occupation and use of its equipment and facilities.

The American railroad rate has always been recognized as covering the full service which the carrier gives-furnishing the car and a proper place at which to load it, the conveyance of that loaded car, and its terminal delivery. In America the charge for these various services is not broken up into its component parts and a charge

"Advances in Rates-Western Case, 20 I. C. C. 307. 
imposed for each, as in England. The rate which must be published is a complete rate, which includes not only a charge for the haul but a charge for the use of the terminals at both ends of the line.

There are dozens of elements which have been considered in the fixing of reasonable rates. Some naturally have been given greater weight than others. The more important have been as follows: the bona fide investment of the carrier, its capitalization, car-mile or trainmile revenue, cost of operation, cost of service, distance of haul, character of equipment furnished, fixed charges, long continuance of a prior low rate, competition of markets, competition by other railroads or by water carriers, necessity for more revenue, character of improvements, previous haul on raw material where the manufactured product is shipped out, profit of the shipper, reproduction value of the railroad, risk of loss or damage, size of community served, value of commodity hauled, value of service rendered, volume of traffic, and weight and character of shipment.

As a practical proposition, the proof concerning the unreasonableness of individual rates is often different from that pertaining to an entire system of rates. The investment of the carrier, for instance, in carrying a specified kind of traffic, such as piano traffic, cannot be ascertained; so in such instances the most common method of proof is to compare the rate attacked with rates on similar commodities transported under similar conditions, either by the defendant carrier or by other railroads. Of course, on heavy commodities, such as coal, lumber, and the like, where such traffic constitutes from one-third to two-thirds of the entire freight traffic of the carrier, accountants often endeavor to ascertain the investment of the carrier in such traffic, and the actual cost of the service. If such statistics are accurately ascertained, they are very im- 
portant in the determination of what is a reasonable rate for such traffic.

At least one of these elements, or all of them together with many others, may be considered in the fixing of any one particular rate. Generally speaking, however, the following is true: Once the comparative cost for various services is learned, a schedule of rates may be made which will approach justice as to the services. Supplement this with scientific classification of freight, giving due weight to all the various factors, such as value, bulk, and hazard, especially to value; add return for use of plant, and force is given to every factor. ${ }^{16}$

It should be noted that the rates of telephone and telegraph companies and the like rest upon a somewhat different basis from that of rates of railroads. However, as such companies are public-service companies and are subject to the provisions of the law that prohibit undue preference and unjust discrimination on any grounds whatsoever, it is manifest that nothing but a difference in the services rendered or in the facilities furnished would justify any difference in the charges exacted. The telegraph and telephone companies are permitted to classify their messages into day, night, unrepeated, etc., and to enter into contracts for the exchange of services with common carriers.

Jurisdiction of Commission over classification.-Inasmuch as the Act confers specifically upon the Commission the power to regulate classification, it may be well to examine briefly into the subject. As the reader knows, classification is that arbitrary division of freight into classes by which a rate is provided for each class. ${ }^{17}$ It is a matter of extreme importance into what class

\footnotetext{
${ }^{16}$ Advances in Rates-Western Case, 20 I. C. C. 307.

"The subject of Freight Classification is fully explained in the treatise on that subject.
} 
commodities are placed, because in the absence of a specific commodity rate the class rate, that is, the rate dependent upon the classification, governs. In the absence of statutory restriction, a carrier is entitled to establish reasonable rules and regulations governing the manner and form in which it will receive such articles of commerce as it is bound to carry, as well as the manner in which they shall be packed and prepared for shipment, so that they may be delivered with convenience, safety, and dispatch. The carrier has also the power to alter and modify such rules from time to time as it may deem proper and expedient upon reasonable notice to the public. $^{18}$

Where the classification primarily affects and controls the rates or charges demanded or collected by the carrier, or publishes the regulations or practices affecting rates, the Commission is authorized to pass upon such rates, charges, regulations, or practices. ${ }^{19}$ But a classification will not be changed by the Commission unless it fairly appears that a particular article is not rated with other articles similar in value, weight, and other essential transportation qualities.

The Commission, of course, has the power to determine. the reasonableness of the difference made between the rates on various kinds of commodities. It cannot say, however, that a rate shall be fixed so as to meet the requirements or needs of any body of shippers in their efforts to reach a given market; nor can it establish rates upon any articles so low that they will not be reasonable. It cannot fix an entire schedule of rates which will give an inadequate return upon the fair value of the property used in the service given. There is, however, a zone within which it may properly exercise "the

${ }^{28}$ U. S. v. Ore. R. R. \& N. Co., 59 Fed. $975,979$.

${ }^{10}$ Nat'i Hay Ass'n v. M. C. R. R. Co., 19 I. C. C. $34,38$. 
flexible limit of judgment which belongs to the power to fix rates.' However, the Commission will not approve the imposition by carriers of conditions which would benefit one or few shippers and which might injure others. In other words, the same rules apply which govern the rate, because the classification is inseparably a part of the rate.

In this connection it should, however, be noted that very often carriers publish so-called "commodity rates." These are rates applying to the specific commodity named. The naming of such a rate takes the commodity referred to out of the classification, and the shipment of that commodity is governed by the commodity rate tariff and not by the classification, so far as the rates are concerned, although the rules of the classification often govern to some extent.

In the formation of a classification the rules, regulations, and charges thereunder must be made with reasonable regard for the nature of the commodity transported and without undue discrimination as to localities or shippers. $^{20}$ Also, in all classifications consideration must be given to what may be termed public policy. There is an advantage to the conmunity in having some kinds of freight carried at a smaller rate than other kinds. However, the fact that certain traffic is hauled in train-load lots while other traffic moves in carloads must not be made the basis of a difference in rates. Carriers, however, may make a difference between carload and lessthan-carload shipments. In forming a classification no one consideration is controlling. Bulk, value, liability to waste or injury in transit, weight, form in which tendered, etc., must be taken into consideration. It is not an exact science, nor may the rating accorded a particular article be determined alone by the yardstick, the

${ }^{20}$ Sunderland Bros. Co. v. S. L. \& S. F. R. R. Co., 23 I. C. C. $259,262$. 
scales, or the dollar; the volume and desirability of the traffic, the hazard of carriage, and the possibility or probability of the misrepresentation of the article are considerations of prime importance. At best it is but a grouping, and when the approximate result from it is not found to cause the exaction of an unreasonable or a discriminatory charge it will not be disturbed. ${ }^{21}$

Bills of lading.-It is the duty of carriers to establish and observe reasonable regulations, and to issue bills of lading or receipts for property received. The Commission has authority to consider and determine the reasonableness of regulations and practices with respect to the issuance and substance of bills of lading, and to determine and prescribe what regulations and practices are just and reasonable. The Commission did in fact hold a hearing on what would be reasonable provisions to insert in a bill of lading. It drew up two forms of what is known as the uniform bill of lading, which it submitted for adoption to the carriers, but it did not order them to adopt these forms. Such bills of lading are designed for use with respect to miscellaneous freight and general merchandise, but are not intended to supplant bills issued on particular commodities requiring. exceptional provisions, such as live stock and perishable property. However, having approved these bills of lading does not preclude the Commission from passing independent judgment upon any of their provisions. ${ }^{22}$

Same subject: Duty of carrier to issue.-It is the duty of carriers to issue bills of lading or similar receipts for the transportation of property entrusted to them. Bills of lading are generally for local movements, through movements, or export or import movements, and they

${ }^{\text {n }}$ Forest City Freight Bureau v. Ann Arbor R. R. Co., 18 I. C. C. $205,206$.

${ }^{22} 14$ I. C. C. 351,355 . 
cover passage by water as well as by rail. A railroad formerly was not compelled to issue a bill of lading covering shipment over a connecting carrier, but could limit its liability and issue a bill of lading for only its own line. The Carmack Amendment (discussed on page 167) practically compels a carrier to issue a through bill of lading, because it makes the initial carrier responsible for any damage occurring to the shipment on the line of a connecting carrier and provides that no provision of the bill of lading shall exempt it from such liability. There is no legal obligation on a rail carrier to give a through bill of lading covering morement by water beyond its line until the Commission, under the amendment of 1912, has made such a requirement. Such practices, however, are of great advantage to shippers, and if given in the name of one boat line should be given in the name of other lines which are similarly circumstanced.

A railroad may entirely destroy the export traffic of a port by refusing to issue through bills of lading, and to say that it may exercise this great power wantonly and arbitrarily is contrary to the spirit and letter of the Act. If the rail carrier makes a rate and issues a bill of lading for shipside delivery at a port, that rate and a similar bill of lading should be open to all who conform to its reasonable conditions. A railroad cannot adopt a policy or practice which will put its facilities and rates at the exclusive service of one line of steamships or of one set of shippers patronizing that line. ${ }^{23}$

Questions very frequently come up as to the duty to issue bills of lading at transit points, or one bill of lading for several shipments. Commodities such as grain are carried from the farm to some elerator or mill located at a designated transit point and there cleaned, sorted or milled, and sent through to destination. Tariffs very fre-

"Mobile Chamber of Commerce v. M. \& O. R. R. Co., 23 I. C. C. 417. 
quently provide that the shipment has to pay the local rate up to such point and when shipped out from there a through rate is assessed from the originating point to destination. The shipper pays the through rate less the local to the transit point and not the sum of the local rates from the originating point to the transit point and from there to destination, which would be considerably higher. The rule is therefore laid down that when carriers are parties to a milling-in-transit privilege it is proper for the inbound carrier to issue and sign the bills of lading for the outbound movement, because since the records of the inbound shipment are in its possession, in no other way could the transit privilege be protected against abuse.

Most classifications contain a provision that when the minimum carload weight or more of one article is shipped in one day in separate shipments by one consignor to one consignee and covered by one bill of lading, the rate for a carload shall apply on the entire lot, althongh it may be less than two or more carload lots. It must be borne in mind that to take advantage of this rule in the classification a separate bill of lading must not be taken out for each shipment, but the railroad agent must be requested to make out one bill for both shipments.

Same subject: Construction.-It must be noted that the bill of lading is little more than a receipt for the goods to be transported and nothing obnoxious to the law can be incorporated into it. It must be plain and definite in all its provisions and must clearly state the liability imposed. For instance, when a car is weighed at origin and the weight is stated in the bill of lading, the shipper has a right to rely on that weight subject to correction only by proof of the correct weight. The statements in the bill of lading are only prima facie. They 
are not controlling, but, as in the case of any other receipt, it may be shown that the actual facts are different.

Any provision in a bill of lading is outside of the tariff, and therefore in no sense a limitation upon the right of the shipper to have his commodity transported in a manner and at the rates specified in the rate schedule. Very often there is a conflict between the rate and the route specified in the bill of lading; that is, through some error or mistake the rate specified in the bill of lading does not apply via the route indicated. In case there is an inconsistency between a rate and a route when both are named in the bill of lading furnished by the shipper, the carrier should request of the shipper which one is to be followed. If the initial carrier fails to inquire of the shipper and routes the freight over a route which carries a higher rate than shown in the bill of lading, it is responsible for misrouting. ${ }^{24}$

Tickets.-A carrier must similarly enforce reasonable regulations governing tickets and the privileges available thereunder. This applies to such things as stop-over privileges, round-trip tickets, and commutation fares, excursion fares, mileage tickets, and the like. While, as will be seen, the shipper of freight is presumed to know the various tariff regulations, it does not appear that the passenger is held to as strict an accountability of the rules governing tickets. Thus, where tickets must be presented for signature to the carrier's agent at various places to secure privileges or for validation and the like, and through an error of the carrier's agent the rules are not complied with and the passenger is thereby compelled to pay an additional charge, damages will be awarded for such error.

Baggage.-The carriers have the right to make reasonable regulations concerning the carrying of baggage.

"Block Pollack Iron Co. v. H. E. \& W. T. R. R. Co., 19 I. C. C. 505. 
Thus, it is not undue discrimination to carry free 150 pounds of baggage for a passenger as against the many passengers who travel without baggage. The carriers may also, within reasonable bounds, limit the size of sample trunks and the like in order to exclude bulky or cumbersome shapes that occupy an undue proportion of space compared with their weight. The carriers have also a right to linit the amount of free baggage to 150 pounds, and to charge extra for baggage over that weight.

Facilities.-It is also made the duty of the carrier to establish and enforce just and reasonable regulations concerning the furnishing and using of facilities. Facilities, of course, are almost as numerous as the instrumentalities of transportation. In general, however, facilities belong to one of three classes: those furnished at the beginning of transportation, during transportation, or at delivery. The most important facility, of course, that the carrier furnishes is the car which moves the commodity. It was perhaps discrimination in the furnishing of cars as much as anything that led to the passage of the Interstate Commerce Act. It is very obvious that by neglecting to furnish cars or by delay in transporting them a shipper can be irretrievably injured, and as a matter of fact such has very frequently been the case. The question of car facilities has come up more often in the case of coal-mining companies than in any other particular industry. Various methods have been adopted by which it has been attempted to give one mine more cars than another. After a great deal of litigation it has been well established that most of the methods of distributing coal cars in effect by the various railroads were wrong in that certain favored mines secured relatively more cars than their competitors. The Interstate Commerce Commission, however, has quite effectively de- 
stroyed all such discrimination, so that today, on the whole, coal cars are equitably distributed.

During transportation the principal facilities that are used are transit, elevation, and compression. Transit is the privilege of holding some product en route to permit it to be manufactured into a finished article and have such finished article reshipped at the balance of the through rate. An example of this would be in the case of transit on logs. They are frequently brought into the mill, manufactured into lumber, and reshipped. Compression is the privilege extended to the shipper of cotton, by means of which the raw cotton is taken into the transit point, compressed, baled, or ginned, and reshipped at the balance of the through rate. Elevation applies to grain and is the privilege of bringing the newly harvested grain into the transit point where it is cleaned, clipped, and sorted. Concentration is another privilege very frequently given, which permits the jobber in eggs, for instance, to draw his eggs in from the surrounding country and reship them out. Other privileges and facilities extended during transportation are reconsigned, refrigeration, substitution of tomnage, and the like. The principal facilities at destination are switching, wharfage, and weighing. In extending these the carrier can make reasonable regulations. It camnot, however, create any that will discriminate against persons equally situated; but the facilities extended must be open impartially.

Sometimes these facilities are extended and performed by the railroads themselves; sometimes they are performed by independent agencies or by the shipper. In the latter case, an allowance is made for such service by the railroad. In other words, it pays so much for the service. Making these allowances has furnished a very fruitful field for rebating, but the Commission is slowly, yet surely, stamping it out. 
Free transportation.--Section 1 is intended to limit the extent to which free transportation can be given by the railroads. Before the passage of this Act the railroads lost millions of dollars a year through the promiscuous giving of passes. It might be said that almost anyone of any consequence in the country could have a pass. After the strict enforcement of the law prohibiting free transportation, all these passes were called in, with the result that the railroads gained millions of dollars in revenue. Generally speaking, it prohibits an interstate carrier from giving free transportation to any person except its officers and employes, ministers, traveling secretaries of railroad Y. M. C. A.'s, inmates of charitable institutions, persons exclusively engaged in charity work, destitute and homeless persons, inmates of soldiers' and sailors' homes, caretakers of perishable property, employes of sleeping and express cars, linemen of telegraph or telephone companies, railway mail employes, postoffice, customs, and immigration inspectors, persons injured in wrecks, cases of general epidemic, etc. Any carrier violating this provision of the Act can be fined not less than $\$ 100$ and not more than $\$ 200$; and the person using the transportation in violation of the Act is similarly guilty. This paragraph, however, should be read in connection with Section 22, which also contains provisions concerning free transportation. It should be observed that the law is not by any means a dead letter, and that prosecutions have been brought against persons riding on passes to which they were not entitled. ${ }^{25}$

Where a railroad employe is entitled to receive a pass, gets one, and delivers it to a friend who rides on it, he is guilty as well as the friend, because the statute intends that all persons making use of any interstate free pass are liable, unless excepted by the terms of the Act, and

\footnotetext{
${ }^{20}$ U. S. v. Martin, 176 Fed. 110; U. S. v. Williams, 159 Fed. 310.
} 
if the person who uses the pass is not so excepted, the person who gives him the pass, even if he himself could use it, is liable. ${ }^{26}$

It might be noted here that all the provisions of this Act so far as they relate to criminal offenses should be read in connection with the Elkins Act. ${ }^{27}$

An important thing to be remembered in connection with Section 1 is the fact that the Act invalidates all contracts for free transportation made prior to its date.

Very often in consideration of a right of way or of a release for personal injuries, a railroad would agree to give free transportation for life to some particular person. Such contracts were invalidated by the Act. ${ }^{28}$

Commodities clause.-Paragraph 5 of Section 1 is what is known as the commodities clause. This prohibits any railroad to transport in interstate or foreign commerce any article or commodity other than timber and the manufactured products thereof, manufactured, mined, or produced by it or under its authority, or which it may own in whole or in part, or in which it may have any interest, direct or indirect, except such articles or commodities as may be necessary and intenrled for its use in the conduct of its business as a common carrier. This paragraph has been held constitutional. It is not void because of the exception contained therein as to timber. It does not deprive railroads of property without due process of law, does not discriminate between carriers, is not void because of the nature and character of the penalties it imposes, but is inherently within the power of Congress to enact as a regulation of commerce. ${ }^{29}$

This clause was passed principally to attack the great coal-carrying and coal-owning roads of Pennsylvania,

${ }^{20}$ U. S. v. Williams, 159 Fed. 310.

2:This Act is reproduced at the end of this treatise.

${ }^{28}$ L. \& N. R. R. Co. v. Mottley, 219 U. S. 467.

${ }^{20}$ U. S. v. D. \& H. Co., 213 U. S. 366. 
such as the Reading, Lehigh Valley, Pennsylvania, and Lackawanna \& Western. It has been estimated, for instance, that the Reading owns 57 per cent of all the anthracite coal mines of the country. A great deal of discrimination had been practiced by these railroads against individual operators, and in favor of their own mines. It was thought that this law would compel the railroads to sell their mines. The practical effect, however, has been to make the coal-carrying roads organize coal companies and transfer the coal mines to the coal companies. The stock of the coal companies was then distributed as a dividend among the stockholders in the railroad company. However, as the stockholders in the railroad are also the stockholders in the coal company, it is very obvious that the commodities clause cannot have accomplished very much, especially since the Supreme Court of the United States held that the prohibition in the commodities clause does not apply to commodities owned by separate corporations in which the carrier owns stock. ${ }^{30}$

Switching connections.-This section also provides that any common carrier, upon application of any lateral branch line of railroad, or of any shipper tendering interstate traffic for transportation, shall construct, maintain, and operate upon reasonable terms a switch connection with its railroad where such connection is reasonably practical and ean be put in with safety and furnish sufficient business to justify its construction and maintenance; and the carrier shall furnish cars for the movement of such traffic and without discrimination in favor of or against any such shipper. If the railroad refuses to install such connection, the applicant can then notify the Commission as provided in Section 13 and the Commission is then empowered to investigate the situation and order the switch to be put in at reasonable cost.

${ }^{10}$ U. S. v. D. \& H. Co., 213 U. S. 366. 
It should be noted that this paragraph does not give the Commission authority to order a side track to be built. It only refers to the switching connection. Thus, where a shipper had made an agreement that it would grade and prepare a roadbed upon which a railroad company agreed to construct a side track connected with its main line and operate the same, and then refused to carry out the agreement, it was held upon application to the Commission that it had no jurisdiction to enforce the specific provisions of an agreement of this nature, and that it was a condition precedent to the exercise of its power that such a private track should be actually constructed in such a manner that a physical connection is practicable and safe.

It must also be noted that while formerly the application to the Commission for a switch connection between the main line and a branch line could only be made by a shipper, and not by a carrier, the law was amended in 1910 to give the carrier this right. So such cases as the reader may come across, denying the right to the carrier, are now obsolete. ${ }^{31}$

A road is a lateral branch road within the meaning of this section, when it is tributary to and dependent upon another for an outlet, and where it is essentially a feeder contributing traffic and capable of exchanging such traffic with other roads. It is not such where it is in effect an independent and competing line. Nor is this any less the case because it may not compete as to a portion of the territory involved. The question is to be determined according to the relation which the branch line bears to the railroad with which a switch connection is asked. This relation is one of road to road and not of shippers or territories. A road does not have the relation of branch or lateral road as to some shippers in its territory

"I. C. v. D. L. \& W. R. R. Co., 216 U. S. 531. 
and not have it as to others. In determining whether a switch connection to a small line reaching several industries and a trunk line should be ordered, a fair test is whether such a complaint would be granted were it an application for a side track to an industry.

It has been held that fifty carloads of traffic a year will justify the commection. ${ }^{32}$ Where a comnection can be safely and easily made, however, there is no doubt that less traffic than this would justify it. It should be recalled that an electric line is entitled to a switch connection with a steam road, as this question very often arises. ${ }^{33}$

As a switch connection generally involves the operation of a side track, it is important to note low far the railroad can go in making regulations, which it undoubtedly will do before it will agree to operate the track. Generally, the railroad will refuse to operate a side track unless its standard form of industrial side track agreement is signed, one clause of which requires the industry to indemnify it from liability on claims for loss and damage by sparks of burning coal from its locomotive on the spur track. Inasmuch as it is no part of the duty of the railroad either at common law or under the Act to spot cars at warehouses or factory or to do more than set them on the spur track, not on its own right of way, if it undertakes to do so there is no reason why it may not predicate its undertaking upon the condition it shall not be liable to the industry for fire losses. The operation of a private side track by a carrier is a different matter from the operation by it of a connection between its line and a side track. If the requisite statutory conditions are complied with, the shipper may insist that the connection be made, whether desired or not by the carrier, but in undertaking

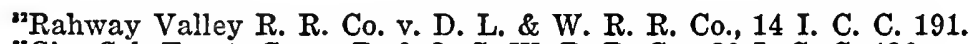
"Cin. Col. Tract. Co. v. B. \& O. S. W. R. R. Co., 20 I. C. C. 486. 
a service on a spur track off its own right of way, the carrier may attach reasonalble conditions to the undertaking. In connection with this subject, it should be borne in mind that Section 6, as amended by the Panama Canal Act, provides that the Interstate Commerce Commission may order physical connections between rail lines and the docks of water carriers where the Commission finds that such connections are practical.

The connecting-up of rail lines with tracks already existing on boat-line docks will often mean a very material saring in time and expense of handling freight. 


\section{SECTION 2}

Crimes.-This section provides that if any carrier subject to the Act shall, either directly or indirectly, by any special rate, rebate, drawback, or other device, charge, demand, collect, or receive a greater or less compensation for any service rendered, or to be rendered, in the transportation of passengers or property subject to the Act than it charges, demands, collects, or receives from any otlier person or persons for a like and contemporaneous service in the transportation of a like kind of traffic, under substantially similar circumstances and conditions, it shall be guilty of unjust discrimination, which is prohibited and declared to be unlawful.

This section of the Act, so far as it relates to rebates, should be read in connection with the Elkins Act, which will be found explained on page 185. Practically all the prosecutions brought for rebating are bronght under the Elkins Act.

So far as this section relates to discrimination, it should be read in connection with Section 3, immediately following.

What constitutes a rebate will be found fully defined in the discussion under the Elkins Act. Generally speaking, however, anything that is equivalent to cash and by means of which a transportation service is performed for less than the public tariffs, constitutes a rebate, which is unlawful. The shipper is presumed to know what the legal rate is. The carrier is presumed to exact that rate. If either the shipper fails to pay or the carrier fails to collect the published rate, an offense is committed. 
It must be borne in mind that a rebate is not necessarily a sum paid by the carrier to a shipper. It may consist of farors which have the same effect. $\Lambda$ contract between a magazine publisher and a railroad by which the latter is to furnish transportation to be paid for by advertising space supplied by the former is in violation of the Elkins Act as amended by the Hepbum Law of June 29, 1906, in that a different compensation is provided for than that specified in the lawfully published tariffs. ${ }^{1}$

Anything by which the shipper gets a reduction from the published rate is a rebate. Hence, paying fictitious loss, damage, or overcharge claims to the shipper is a rebate; so would be the giving of free transportation to which the shipper was not entitled.

This section, so far as the prohibiting of discrimination is concerned, is generally construed to mean discrimination between commodities, while Section 3 prohibits discrimination between localities. Thus, if it is alleged that snapped corn takes a discriminatory rate as compared with the rate on ordinary corn, a violation of Section 2 is involved. If, however, an unduly discriminatory rate is alleged in favor of Smithville as against the rate given Jones City, Section 3 is violated. Section 2 requires similar treatment for "like kinds of traffic," while Section 3 covers not only traffic but localities and persons.

${ }^{1}$ U. S. v. C. I. \& L. Ry. Co., 163 Fed. 114, 115. 


\section{SECTION 3}

\section{Discrimination}

In general.-Section 3 provides that it is unlawful for any common carrier to make or give any undue or unreasonable preference to any particular person, company, firm, corporation, or locality or any particular description of traffic, in any respect whatsoever, or to subject any particular person, company, firm, corporation, or locality, or any particular description of traffic, to any undue or unreasonable prejudice or disadvantage in any respect.

The following is a typical case of discrimination under Section 3. The Traffic Association of Santa Rosa, California, attacked the basis of rates by which that eity was given the rates to the nearest terminal plus the locals therefrom to Santa Rosa as unduly prejudicial to that city and preferential to San Jose, Santa Clara, Marysville, and other California points, which were being granted terminal rates, although not strictly terminal rate points. San Jose and Santa Clara were given terminal rates by the railroads on account of the fact that the ocean carriers absorbed the wagon haul from the terminals to these points. The same was true of Marysville, which was located on a branch of the Sacramento River well beyond the head of navigation. Santa Rosa is 52 miles north of San Francisco, while San Jose is 48 miles south. There was an available route from San Francisco to Santa Rosa by boat to Petaluma, a distance of 46 miles; thence via an electric line, 16 miles, to Santa Rosa. This route was in effect for through traffic in connection with the Western Pacific Railroad at San Francisco. San Jose and Santa 
Clara are from $S$ to 10 miles beyond tidewater and therefore on a water haul from San Francisco, land cartage Was necesary. The same situation applied to Marrstille, at which point the water competition was not actually or apparently potential. On the Northwestern Pacific Railroad Santa Rosa was on the main line, but on the Southern Pacific Railway it was located on a branch line. Santa Clara and Sin Jose were on the main line of the Southern Pacific Railway.

Under the rates attacked. merchants at Santa Rosa were compelled either to lose from their profits on goods an amount equal to the difference in rates between Santa Rosa and the other points in question, or to charge this difference up to the consumer by adding to the sale price. It was held that Santa Rosa bore such a competitive relation to the other cities mentioned as to be unduly discriminated against by the rates attacked, and while the Commission did not approre of the extension of these terminal rates to San Jose, Santa Clara, and Marrstille, so long as the extension was made, defendants must accord terminal rates to Santa Rosa. ${ }^{1}$

It also provides that common carriers shall afford reasonable, proper, and equal facilities for the interchanging of traffic between their respectire lines and for the receiving, forwarding, and delivering of passengers and property to and from their several lines and those connecting therewith; and that they shall not discriminate in their rates and charges between such connecting lines. But the carrier is not required to give the use of its tracks or terminal facilities to any carrier engaged in like business.

Perhaps more litigation has arisen under this section than under any other of the Act. When it is considered that innumerable instrumentalities and facilities are used

${ }^{1 S}$ Santa Rosa Traf, Ass'n r. S. P. Co., 24 I. C. C. 46. 
in transportation and that it is possible to faror one shipper at the expense of another, the questions that hare come up are almost infinite. Absorption of charges, adrances in rates, allowances, blanket rates, car supply; classification, demurrage, differentials, export rates, express rates, facilities of rarious kinds, import traffic, lighterage, passenger fares, precooling, ${ }^{2}$ proportional rates, reconsignment, switching, tap lines, terminal facilities, through rontes, track storage, and weighing are but few of the manr different situations in which discrimination has been practiced.

It must be remembered that it is not every discrimination that is forbidden. It is only such as are undue or unjust. Thus, the mere fact that one point takes a lower rate than another point does not show that the higher rate is discriminatory. Before it can be said that a discrimination is undue, there must alwars exist a similarity of circumstances. Thus, supposing one citr is serred by fire or sis trunk-line carriers. Another cits fiftr miles amar is onl serred by one railroad. Manifestly, the rates to the former would be lower than to the latter because competition would force such rates down to the lowest possible lerel. The following is an example of similarity of circumstances. In the application of rates on coal from the Walsenburg district in Colorado to mumerous points in Nebraska, defendants proride a rate of $\$ 3.50$ per net ton to one group of stations and a rate of $\$ 3.75$ to a second group. Complainant in substance asked that certain points now taking the $\$ 3.75$ rate be included within the $\$ 3.50$ rate gromp and that certain ones taking the $\$ 3.50$ rate be divided into two new groups to which shall apply rates of $\$ 3$ and $\$ 3.25$. A point

\footnotetext{
'A term signifying that fruit is cooled in warchouses or cars before transportation is begun. To a considerable extent this operation does away with refrigeration of cars.
} 
known as Minden on the main line of the Burlington took the $\$ 3.50$ rate, while a station known as Minden " $K$," on a subsidiary line of the Burlington system, which also passes through Minden, took the $\$ 3.75$ rate, although it is only a few blocks from Minden; but there is no physical connection between these two lines. It was held that the lack of switch connection between the lines of the Burlington system at Minden and Minden " $\mathrm{K}$ ", should not be allowed to prejudice the latter station, and that Minden " $K$ " should take the same rate as Minden, and under the readjustment required by this finding the rate to Minden " $\mathrm{K}$ " should not be exceeded at the intermediate stations of Keene, Wilcox, Ragan, Huntley, Alma, Orleans, Carter, and Sacramento, Nebraska. ${ }^{3}$ Typical problems of unjust discrimination have been considered in the Cedar Hill coal case, ${ }^{4}$ the Colorado Coal Traffic Association case, ${ }^{5}$ and the Nebraska State Commission case. ${ }^{6}$

If the same carrier serving both Kansas and Detroit salt fields names a lower rate to St. Lonis, for substantially the same distance from Detroit, than from Kansas, it must be prepared to justify that discrimination; but if carrier A serves St. Louis from the Kansas field, while carrier $\mathrm{B}$ serves that market from the Detroit field, then carrier $\mathrm{A}$ is not guilty of discrimination because it declines to meet the rate established by carrier B. ${ }^{7}$

The making of lower rates for carload lots as against less-than-carload lots is an example of discrimination that is generally conceded not to be unjust, although the making of such lower rates discriminates against the small shipment.

${ }^{8}$ Nebr. St. Ry. Com. v. C. B. \& Q. R. R. Co., 23 I. C. C. 121.

'16 I. C. C. 387.

${ }^{5} 19$ I. C. C. 478.

13 I. C. C. 349 .

'R. R. Com'rs of Kan. v. A. T. \& S. F. Ry. Co., 22 I. C. C. 407-413. 
As it is impossible to cover the subject of discrimination pertaining to each kind of rate or instrumentality, nothing more is attempted here than briefly to lay down the elementary principles which generally govern these questions.

Control and regulation of discrimination.-The Act was intended to be an effective means for redressing wrongs resulting from unjust discrimination and undue preference. There persons and places suffer, the fundamental principle of the Act is one of fair play. A railroad may not control the character of the industries along its line by giving preferential rates as between commodities, nor discriminate as between one shipper and another even though by following the last procedure it can develop the greatest amount of traffic for itself. However, the Act does not prohibit all discrimination, but only that which is undue. ${ }^{8}$

Jurisdiction of Commission.-The primary jurisdiction over unjust discrimination by carriers is with the Interstate Commerce Commission, the power of the courts being that of review. The latter are confined in that review to questions of constitutional power, and whether the action of the Commission is within the scope of its. jurisdiction. Thus, the Commission cannot indulge in speculation as to the motives which actuated carriers in fixing an adjustment of fieight rates as between various points of origin, but can only determine upon the facts and conditions whether or not the rates in question are unreasonable or unjustly discriminatory. The courts look upon the Commission as qualified by experience and from the nature of its duties to speak as experts with respect to the rates and practices of carriers, and ascribe to its findings the weight and conclusiveness that are ordinarily attached to expert opinions.

'Herbeck-Demer Co. v. B. \& O. R. R. Co., 17 I. C. C. 88. 
Shippers may resort to the Commission for the redressing of injuries arising out of the exaction by common carriers of unlawful rates. The Commission has jurisdiction over any regulation or practice that withdraws from a shipper the equal opportmity of using and taking advantage of the rates offered by a carrier to the public, or any adjustment of rates that discriminates between persons or localities similarly situated. In all inquiries as to the jurisdiction of the Commission, reference should be had especially to Section 15, which particularly defines the Commission's power.

Determination of discrimination.-A railroad must serve all shippers, traffic, and localities with substantial equality. It must extend the same facilities and service to every locality. Only a difference in transportation conditions can justify granting one locality an advantage over another. The fact that a given town can do a comparatively small amount of business is no justification for excluding it from the opportunity to get what it can. Cases of alleged undue preference or prejudice, however, must be adjudged upon their respective merits and cannot be controlled by the results of other controversies supposed to be of like nature. However, a railroad is justified under the law in discriminating in favor of one city as against another if the cities are so differently circumstanced that at one point transportation forces are brought into play which are not or cannot be exercised at another point; but a carrier is not justified in deliberately adopting a policy of preference torards one city as against another. In order to be undue, the preference must be towards one eity as against another, and must give an advantage created by the mere policy of a carrier and not by reasons of actual difference in conditions. Good faith, moreover, will not save a transaction from condemnation if it involves unjust preference. 
Where one railroad is owned by another, although operated entirely separately, the Commission is supposed to regard the two railroads as one in determining whether the rates established by them unduly discriminate between different sections. Evidence of a harmful result in a given case need not be sought by the Commission. It would be a vain attempt in many cases to undertake to ascertain with reasonable certainty just what has resulted and who has been injured by transactions of the kind. The lawmakers, assuming that such practice would naturally result in many instances in favoritism and irreparable wrong, have enacted the law which adjudges the practice itself to be wrong and forbids it.

Whether or not discrimination is undue is a fact to be found, not a matter of law. Carriers are common servants of all shippers and are bound to serve them reasonably and without undue preference. It is the duty of a common carrier to receive and carry upon reasonable terms goods tendered in a suitable condition and it cannot lawfully discriminate in favor of any person, product, or locality. It is difficult to determine that one theory is reasonable and right for one manufacturer and shipper and another theory is reasonable and right for another manufacturer and shipper under substantially similar circumstances and conditions. Under the Interstate Commerce Act, however, differential and discriminative rates are lawful so long as they are not unduly discriminatory and do not operate unfairly, and the essence of the Act is that whatever the rate is it shall be the same to all persons similarly situated.

What is an undue or unreasonable preference or charge under Section 3 of the Act is a question of fact, but subject to the various circumstances rates ought to be relatively equal and reasonable. A carrier has no right to make rates so as to overcome the natural advantages of 
one place over another, or to build up one place or section at the expense of another.

It should be noted that when general rate adjustments and rates blanketed over large areas which contemplate substantial justice among all shippers result in individual instances of inequality, they fail in their purpose to that extent. Their strict observance in such cases upon no other ground than the arbitrary theory of their existence should yield as far as is necessary to prevent gross injustice, just as other general rules are subject to exceptions.

The following is a typical case where discrimination was found to exist. On shipments of coal for railway use from the district near Wheeling, West Virginia, defendant carriers extended much lower rates than when the coal was to be used for other purposes. It was held that such practices on the part of the carriers ought to be stopped as resulting in unjust discrimination in favor of producers having contracts for the sale of coal to carriers. There is no warrant in the common law or the Act for the theory that a carrier as a shipper over the lines of other carriers may be given a preferred rate. The practice cannot be upheld without removing the very corner stone of the Act designed to prevent unjust discrimination and practices. If carriers insist upon making or maintaining such preferential rates they may confidently expect that such voluntary action on their part will be accepted in any further proceedings in this or any similar cases as evidence of the unreasonableness of higher rates which they may undertake to enforce against other shippers. ${ }^{9}$

Rates on vehicles from Chicago to a considerable part of the South and Southeast were made and largely controlled by the direct line of the Illinois Central Railroad,

'Hitchman Coal \& Coke Co. v. B. \& O. R. R. Co., 16 I. C. C. 512, $517,518$. 
the short-line carrier. Defendants elected to meet, via their lines and the various Ohio River and Virginia Cities gateways, the rates so made from Chicago and to accord somewhat similarly favorable rate adjustments to other points east of Chicago. They refused to accord these rates to traffic from Toledo to Ohio River Crossings and to Virginia Cities destined beyond these basing points to the South and Southeast. It was held that carriers may not select certain points of production on their lines, giving them the benefit of rates that permit meeting the competition of producers located upon other lines, and denying such advantageous rates to other producing points upon their lines that are similarly situated, and as to which the same long-established basis of rates applies, and that the practice indulged in resulted in unjust discrimination..$^{10}$

The following is a case where discrimination was found not to exist. Point Pleasant, New Jersey, is two and one-half miles south of Seagirt, New Jersey. Manasquan lies between Seagirt and Point Pleasant. Bay Head lies one mile south of Point Pleasant. The Pennsylvania Railroad, approaching from the south, reaches all these towns. On coal from Pennsylvania mines it charged $\$ 2.05$ to Bay Head and Point Pleasant, and only $\$ 1.90$ to Manasquan and Seagirt. The lower rate to Seagirt and Manasquan was compelled by the competition of the Central Railroad of New Jersey, which was the short-line route reaching Seagirt and Manasquan, but which did not reach Point Pleasant. To lower the Point Pleasant rate would have the effect of disturbing the rate to points in the South grouped by the Pennsylvania Railroad with Point Pleasant. No evidence was offered of the unreasonableness per se of the Point Pleas101.

${ }^{10}$ Milburn Wagon Co. v. L. S. \& M. S. Ry. Co., 22 I. C. C. 93,100 , 
ant rate. It was held that such rate was not unduly discriminatory against coal dealers at Point Pleasant. ${ }^{11}$

Justification of discrimination: Carrier as shipper or consignee.-Nany reasons have been urged to justify discrimination. Railroads are necessarily large purchasers of commodities such as coal, steel, oil, and the like. Frequently, lower lates are charged for these commodities when for railroad use than when they are sold for other purposes.

It is now well settled that a carrier as a shipper over the lines of another carrier may not have any preference in the application of transportation rates and charges. Conversely, it may have the same privileges under the tariffs as any other shipper.

Same subject: Carrier not serving prejudiced point. -Very often carriers are charged with discriminating against some city to which their rails do not actually extend. It was originally thought that a carrier could not be guilty of discrimination against a locality to which its line of road did not physically extend. The rule has now been stated to be that a railroad cannot be said to discriminate against a town it does not reach and in whose trade it does not participate. If, however, a carrier is a link in a through route that does participate in the trade of a locality it may be cliarged with being guilty of discrimination. The fact that its rails do not actually extend to the shipping center discriminated against cannot relieve it from responsibility for the effect of rates creating such discrimination which it controls and in which it participates. However, a line not serving a particular point cannot be said to discriminate against it in any rate adjustment created by circumstances beyond its control, though as a connecting line it may participate in the rates imposed.

${ }^{2}$ Ocean Co. Coal Co. v. Central R. R. of N. J., 17 I. C. C. $383,384$. 
Neither can it be said to discriminate against a point served by it because other carriers have lower rates to the same place from points on their own lines.

The following case is illustrative. The rates on petroleum from Coffeyville, Kan., to Memphis, Tenn., are higher than those from Whiting, Ind., and from Illinois points to Memphis, but there is no unjust discrimination against Coffeyville because the carriers serving Coffeyville are not those serving Whiting and the Illinois points. ${ }^{12}$

Same subject: Competition in general.-Perhaps the excuse urged more frequently than any other to justify discrimination is that greater competition may exist at one point than another. In considering a question of discrimination, competition is an important element to be taken into account. Competition as a controlling force cannot be ignored by the Commission in determining whether a change in rate at the competitive point is undue or is one not chargeable to the carriers because involuntarily made. Competition which compels lower rates to one city than to another city similarly situated may justify such rate adjustment; but the mere fact of competition, regardless of its character, does not relieve carriers from the limitations of Section $3 .^{13}$

While competition at a given point may render the circumstances substantially dissimilar and justify a discrimination against points where such competition is not controlling, such dissimilarity of circumstances does not relieve the carrier altogether from the restraint of Section 3, and the amount of discrimination must not be greater than the dissimilarity of circumstances demands. Moreover, the carrier cannot be permitted to compete at

${ }^{12}$ Nat'l Petroleum Ass'n v. M. P. Ry. Co., 18 I. C. C. 593, 594.

${ }^{13}$ Chamber of Commerce of Newport News v. S. Ry. Co., 23 I. C. C. $345,353$. 
one point and decline to compete at another where all conditions are the same.

There are various kinds of competition, which may be stated as artificial, potential, rail, and water.

Same subject: Potential competition:-Potential competition is the possibility of actually dereloping competition. Thus, the possibility of actual competition developing on a river, for instance, justifies a slight difference in rates between a river point and one not so situated. For instance, the competitive influence of the Erie Canal has to a considerable extent disappeared, but it still produces profound effect upon grain rates from Chicago to the Atlantic seaboard. ${ }^{\mathbf{1 4}}$

Same subject: Railroad competition.-Railroad competition is that which exists through the fact of more than one railroad serving the same point. Where such a situation exists it is obvious that the railroad giving the lowest rate will get the business. Moreover, it may well happen that one road will have a shorter line to a certain destination than another. It will, therefore, cost that carrier less for transportation and at the same time afford to the shipper more expeditious service. In order to obtain any sort of business, the carrier with the more circuitous route must meet whatever rate the short-line carrier sees fit to publish, or else retire from the business altogether.

The Commission cannot compel any carrier to meet competition. Thus, if the long-line carrier does not see fit to meet the rate established by its competitor it cannot be compelled to do so. It cannot, however, compete at one point and refuse to compete at another similarly situated. The greater the number of carriers serving a shipping center the more intense the competition. Such

"Board of Trade of Chicago v. A. C. R. R. Co., 20 I. C. C. $504,507$. 
competition is a complete justification for lower rates for such a locality than to one not so situated.

Thus, most of the great systems in Official Classification Territory have existed in substantially their present form for the past twenty-five years. Originally, there was the most active competition in the rate of transportation by rail, and the tariffs in Official Classification Territory are largely the product of that competition. There is a strong presumption that rates so arrived at are reasonable rates. ${ }^{15}$

Same subject: Water competition.-Among the reasons frequently urged as an excuse for discrimination is that water competition may exist at the favored point. Water competition at a given point may render circumstances and conditions dissimilar and justify discrimination against points wliere such competition is not controlling. Carriers may, for the purpose of meeting water competition, make rates lower than would otherwise be justifiable, even to the extent of charging a less rate to the more distant point.

The carrier may determine for itself whether it will or will not meet such water competition. While, however, it may in the first instance settle its policy in this respect, it must act under certain limitations. It cannot be permitted to compete at one point and decline to compete at another where the conditions are the same, nor should it be allowed to compete one day and decline to compete the next.

The public has the right to require equal and uniform treatment within the bounds of reason. Cases might arise where the Commission would require the continuance of a rate established to meet such competition. ${ }^{16}$ Under the

${ }^{13}$ Advances in Rates-Eastern Case, 2 I. C. C. 243, 259.

${ }^{20}$ Darling \& Co. v. B. \& O. R. R. Co., 15 I. C. C. 235, 237. 
law as it exists at present, it is difficult for carriers to raise rates once lowered by water competition.

It must be borne in mind that every city is entitled to the advantage of its location and may not lawfully be subjected to higher freight rates merely because carriers, for reasons of convenience or otherwise, inchude it with a number of other points in surrounding territory, which latter points are not similarly situated. On the other hand, a community is not discriminated against because owing to the disadrantage of its location it is entitled only to such rates as do not allow it to compete with other localities.

Furthermore, the carrier is entitled to encourage the territory it serves. No undue preference results from the fact that a carrier maintains lower rates from points on its own line than other carriers maintain on the same traffic from points near by on their lines. Within certain limitations a railroad may protect its territory and within those limits the Interstate Commerce Commission may consider rates and their effect upon the amount of traffic. In carrying out this purpose the carrier may often adjust its rates to meet so-called market competition. However, market competition is merely a euphemism for railroad policy. The desire of a number of shippers to reach a market is a force to which the carrier may not yield unless it can establish clearly that the adoption of such a policy will not discriminate against one community in favor of another, and will not produce those results which the law was intended to prevent. Neither can a carrier, in order to build up and foster industries on its own line, lawfully refuse to carry the products of like industries located on connecting lines.

It is the equality guaranteed by the Act that the carrier must furnish. Section 3 applies to discrimination against interstate traffic, and the fact that a carrier's rates on 
interstate shipments are established by the Interstate Commerce Commission does not relieve that carrier even in the event of the duty so to adjust its rates as to interstate traffic that justice will be done between communities regardless of state lines.

Thus, with respect to water competition, it is fairly established that the influence of water competition does not cease at the Pittsburgh-Buffalo line, but extends westward as to certain particular commodities. Doubtless, for some distance west of Pittsburgh the carriers may properly make rates which will prevent the movement eastward to the seaboard, instead of westward over their line; but records of the Commission for twenty years fail to disclose any but the most fragmentary evidence that sea competition extends to Chicago. ${ }^{17}$

Removal of discrimination.-It is sometimes very difficult to remove a discriminatory situation, for the reason that rates are more or less interrelated, and to reduce one rate means the disturbance of others. It is, however, well settled that relief against discrimination due to a rate adjustment cannot be denied on the ground that other points similarly situated might thereby be induced. to ask for relief. If unreasonableness and discrimination are present, the Commission will not hesitate to reduce rates because of the threat of a reduction from carriers serving competing localities.

The Commission may remove discrimination either through a reduction in rates to one point, or by permitting the carrier to raise the rate to the farored point. While it is proper to consider the effect of a decision upon the general rate adjustment applying over a wide scope of territory, rates which discriminate against one locality cannot be justified on the ground that they are part of a general scheme adopted by several

${ }^{12} R$. R. Com. of Nev. v. S. P. Co., 21 I. C. C. $329,355$. 
roads entering the same territory. In other words, unreasonable rates or undue and unjust discrimination should be corrected, even if long-standing adjustments must be disturbed.

\section{Facilities}

Interchange of facilities.-Section 3 provides that all common carriers subject to the Act shall afford all reasonable, proper, and equal facilities for the interchange of traffic between their respective lines, and for the receiving, forwarding, and delivering of cars to and from their several lines and those connecting therewith, and shall not discriminate in their rates between such connecting lines. On the other hand, no such common carrier shall be required to give the use of its tracks or terminal facilities to another carrier engaged in like business. Carriers are required to make reasonable rules and regulations with respect to the interchange and return of cars used upon through routes and for the operation of such through routes. Where they have failed in this respect the Commission is empowered to determine the individual and joint rate that is fair and reasonable.

The duty of an originating carrier to furnish equipment for a shipment which moves on to other lines is universally recognized and in cases where that is impracticable or deemed unwise, the carrier is asked to bear the burden of the transfer from the equipment of one line to that of another. The railroads are required, under the Act, to serve the through routes which they have established with other carriers without respect to the fact that in rendering such service equipment may be carried beyond their own lines. However, a carrier generally has no right to send empty cars off its line until it has furnished sufficient cars to its own shippers. The point at 
which traffic is to be interchanged should be determined by the carriers, but the Commission will decide the matter in case of discrimination.

It might be noted here that state legislation, with reference to the duty of carriers to install interchange tracks, is not prolibited where it amounts to no more than a reasonable regulation of an instrumentality of interstate commerce, and affects such commerce only secondarily or remotely. A carrier cannot establish a through route and joint rate except with the concurrence of the other carriers that form parts of such route or by order of the Commission; and in the absence of agreement no connecting carrier is obliged to furnish cars to take shipments from points of origin on another carrier's lines.

Terminal facilities.-A carrier is not required to give its terminal facilities to a competitor. However, if carriers are allowing the use of their tracks or terminal facilities, then the proviso of Section 3 has no application. Terminals are either open or they are not, and if a carrier holds itself out as ready to permit the use of its tracks at a certain charge, the fact that such charge may be prohibitive does not mean that the terminals are not open. On the contrary, it would seem to be a potent argument for the reduction of charges for the use of tracks or terminal facilities already extended. That carriers offer each to the other the use of their respective tracks or terminals, is shown by the fact that freight is actually interchanged after its arrival at the terminal and for this service charges are provided in tariffs published and filed. It follows that having elected to perform this service, the carrier must make its charge reasonable. 


\section{SECTION 4 \\ 1. Long-and-Short-Haul Rule}

In general.-This section is the famous long-and-shorthaul provision of the Act. It makes it unlawful for any common carrier subject to the Act to charge or receive greater compensation for a shorter distance than that exacted for the transportation of persons or any like kind of property for a longer distance over the same line or route in the same direction, the shorter distance being included within the longer distance, or to charge any greater compensation as a through rate than the aggregate of the intermediate rates. Upon application to the Interstate Commerce Commission, howerer, the carrier may, in special cases, after investigation, be authorized by the Commission to charge less for a longer than for a shorter distance for the transportation of passengers or property.

The Commission may from time to time designate the extent to which the common carrier may be relieved from the operation of Section 4, provided that no rates or charges lawfully existing at the time of the passage of that section as amended could be required to be changed by reason of such section prior to the expiration of six months after the passage of the amendment. Likewise, when the application to be excepted from the requirements of Section 4 shall have been filed with the Commission, the provision will not apply until a determination thereof has been made by the Commission.

Whenever a carrier by rail shall, in competition with a water route or routes, reduce the rates on the carriage 
of any species of freight to or from competitive points, it shall not be permitted to increase such rates unless, after a hearing by the Interstate Commerce Commission, it shall be found that such increase rests upon changed conditions other than the elimination of water competition.

The various intermountain cases are, perhaps, the best known of all those which have arisen under Section 4 . Proceedings were brought by the states west of the Rocky Mountains and east of the Pacific coast to obtain relief from the excessively high rates which they had to bear. The railroads for years had maintained lower rates to the Pacific coast from points east of the Mississippi River than they did to the so-called intermountain points, such as Reno, Salt Lake City, Spokane, and the like. The carriers contended that on account of the fact that the Pacific coast was located on the ocean, so that shipments from the East could move through the eastern seaboard and around Cape Horn, they were compelled to maintain lower rates to points on the Pacific coast than to points in the interior. A great many cases were brought by these interior points, forming a group of cases known as the intermountain cases. Finally, under Section 4 as amended, the seventeen carriers applied to the Commission for relief from the provisions of the section. The applications covered the whole territory from the Atlantic seaboard to the Pacific coast and the Gulf of Mexico, embracing practically the entire country. They asked authority to continue all rates on the tariffs presented, from the Atlantic to the Pacific, lower than rates concurrently in effect to intermediate points. The Commission refused to grant their petitions, but entered an order permitting in some respects a charge of a lower rate for the longer haul than was asked for the shorter haul, provided a proportionate relation was maintained 
between them, the proportion to be upon the basis of percentages which were fixed.

For the purpose of the order the Commission adopted in substance a division of the entire territory into separate zones, which division had been resorted to by the carriers for the purpose of establishing the rates in relation to which the petitions were filed. The carriers contended that under Section 4 as amended by the Act of June 18, 1910, the Commission was limited to ascertaining the existence of any competition, and to authorizing the carrier to meet it, without any authority to do more than exercise its general powers concerning the reasonableness of rates at all points.

For the purpose of disposing of the Spokane case under Section 4, the Commission has divided the United States into five territorial zones. ${ }^{1}$

From Zone 1 no higher charge can justly be made at any intermediate point than to a more distant point, and there is no justification for a system of rates which maintains from this territory a higher charge to any interior point than is made to the coast. From Zone 2 the rates to intermediate points may properly exceed by not more than 7 per cent rates from the same points of origin to Pacific Coast Terminals. In Zone 3 the rates from points of origin to intermediate points may properly exceed those to terminal points by not more than 15 per cent. In Zone 4 rates from points of origin to intermediate points may properly exceed those to terminal points by not more than 25 per cent. In Zone 5 no opinion is expressed at this time, since rates from that territory are not involved in these proceedings. ${ }^{2}$

\footnotetext{
'The description of these zones is given in detail in "Freight Rates Western Territory," Part 3.

${ }^{2}$ City of Spokane v. N. P. Ry. Co., 21 I. C. C. $400,425,426$.
} 
The carriers appealed the case to the Commerce Court and the order of the Commission was enjoined. In Atchison, Topeka \& Santa Fe Railway Co. v. U. S., ${ }^{8}$ the court held that the Commission by its orders respecting the relation of rates from eastern points to Spokane, Reno, and other intermountain cities as compared with the rates to Pacific Coast Terminals, established certain zones and entered orders which did not establish absolute rates for either the long or the short haul, or prescribe the extent, in dollars and cents, that the short-haul rate might exceed the present or some definitely fixed long-haul rate; but that it established a relation between any long-haul rate that the carrier might put into effect and the short-haul rate by determining that from Zone 1 the western shorthaul rate should not exceed the long-haul rate, and from Zones 2, 3, and 4 the short-haul rates should not exceed the long-haul rate by more than 7 per cent, 15 per cent, and 25 per cent, respectively. For this reason, the Commission exceeded its authority, since it has no power to say that any given percentage of a known, less-thanreasonable rate to the coast is necessarily a maximum reasonable and non-discriminatory rate from the same point of origin to an interior point. The case was then appealed to the Supreme Court of the United States and that court held that under Section 4 as amended, the Commission is not only authorized to consider competitive conditions and their relation to persons and places, but also has the right to do that by which alone its power could be exerted, namely, the establishment of zones and percentages. ${ }^{4}$

Constitutionality of Section 4.-The Government may properly determine what policy railroads shall pursue so

191 Fed. 856.

'U. S. v. A. T. \& S. F. Ry. Co., 34 Sup. Ct. 986, 994, reversing 191 Fed. 856, enjoining the order of the Commission in I. C. C. 
long as the guarantees of the Constitution are safeguarded. If it is injurious to the interstate commerce of the country and inimical to the public welfare to permit its railroad highways to be used so as to promote unduly the growth and prosperity of one city as against another by charging more to the nearer point, it is then the proper sphere of Congress to prohibit absolutely and completely the pursuance of such policy by the railroads. Therefore, the long-and-short-haul provision of the Act is constitutional.

Jurisdiction of Commission.-Congress has said to carriers of interstate commerce by rail that they must not charge more for the short than for the long haul, unless they can show to the satisfaction of the Commission that in so doing their rates do not violate the inbibition of the Act as expressed in both Sections 1 and 3. The Commission may prescribe the maximum difference in rates which may be made against intermediate points, or may fix a rate at the more distant point below which a carrier must not go, or may define the territory from which a higher intermediate charge may be made. However, the whole situation must be considered by the Commission in passing upon an application for relief from the provisions of Section 4 and in doing so it may inquire whether rates to intermediate points are reasonable.

Exceptions.-It will be noted that this section provides that upon application to the Interstate Commerce Commission the carrier may, in special cases, be authorized to charge less for longer than for shorter distances. These instances are known as exceptions to Section 4 and in this connection the Commission has had a great deal of work to do. In fact, thousands of applications have been filed and it can truthfully be said that at the present time the exception clause is more important than any other part of Section 4. The guide to the exercise of the Com- 
mission's discretion in granting exceptions is to be found in the other sections of the Act. This fact limits the discretion to exempt carriers from the prohibition, and imposes upon the Commission not merely the right but also the duty to grant such exemption whenever on investigation it shall find that no violation of any section of the Act would thereby be involved.

The Commission, in granting exemptions to carriers, may accomplish the result in one of the following ways: (1) By fixing the geographical limit within which there can be no discrimination, and permitting higher rates from other territory to the extent of the competition, which justifies discrimination; (2) it may fix the limit of the rail rate at the more distant point with reference to the rate to intermediate points, thereby prescribing the zone of rate discrimination which may be lawful and justified; or (3) where either of these methods does not seem to be practicable, it may permit the carrier to continue the rates to the more distant point, and, dealing with intermediate points alone, prescribe a reasonable rate which the carrier, as an outgrowth of its policies or its methods of making rates, may not exceed.

In point of law, the Commission has before it, on every application for an exception, the reasonableness of the rates involved in the carrier's application. It was not the intention of Congress to permit a carrier to discriminate in favor of a more distant point to such an extent as to effect not only an undue discrimination against the nearest point, but the imposition of an excessive charge. The relieving power of the Commission is not to be exercised arbitrarily, but it is its duty to permit a higher intermediate charge whenever the resulting rates will not contravene the Act in that they are unjust and unreasonable, or unduly discriminatory. This embraces both 
a preference against the intermediate point and the rate which that point is required to pay. Congress intended to say, by the new Section 4, that as a general rule there should be no lesser charge to the more distant points, but it was not willing to say that there should be no exceptions to this rule. The railroads, however, were not to make these exceptions themselves. Such exceptions were to be made only upon petition to the Commission, their justifiableness being shown. In other words, the burden rests upon the carriers to justify the petition for exception.

Application of Section 4 to rates.-In determining the application of Section 4, a great many questions naturally arise, and these can be touched upon only briefly. Inasmuch as a higher rate for a shorter than for a longer haul is unduly prejudicial to the intermediate point where conditions are similar, the charge for the shorter distance should never exceed that for the longer distance. Cost of service, for instance, is not sufficient justification for a greater charge to an intermediate point. Even if conditions should justify a higher charge to the intermediate point, the intermediate rate should not exceed the long-distance rate plus a reasonable local charge from the more remote back to the intermediate point, and should often be even less. ${ }^{5}$

Competition as justification.-There are three kinds of competition generally urged by carriers as justifying exceptions to Section 4. These are market competition, railroad competition, and water competition.

Market competition.-The condition brought about by the desire of one locality to sell against another in a certain territory is market competition. As an excuse for. justifying the higher rate to an intermediate point, it has

'Bluefield Shippers Ass'n v. N. \& W. Ry. Co., 22 I. C. C. 519, 531; Application of the S. P. Co., 22 I. C. C. 366,374 . 
been absolutely disregarded by the Commission and rejected. To state it briefly, the Commission has held that the history of Section 4 makes it clear that it was born out of a desire and has been actuated by the purpose to restrict the effect of market competition. In other words, market competition has been a railroad policy that the national legislature has seen fit to veto. It can, therefore, be considered as settled that the desire of a number of shippers to reach a market is a force to which the carrier may not yield unless it can establish clearly that the adoption of such policy will not unfairly discriminate against one community.in favor of another, and will not produce those results which the law was intended to prevent.

Railroad competition.-Competition with a short line serving a terminal point may justify a departure from the long-and-short-haul clause by the carriers that serve that point by more circuitous routes. The competition of carriers is a factor to be considered upon application for relief from Section 4. However, while it is permissible to meet competition at a more distant point, the intermediate rate should not be prejudiced by an unreasonably low rate to the more distant point.

Water competition.-Under Section 4 a carrier may, through the existence of water competition, be permitted to charge a lower rate at a more distant point than exists at an intermediate point. Carriers may determine whether they will meet water competition or not. They cannot be compelled to meet such competition if they do not wish to.

Where rates are fixed at certain terminal points by water competition a general custom has obtained of making rates to intermediate points upon the combination of the competitive rates to the terminal rate plus the local rate back. The reasonableness of a rate so constructed 
necessarily depends largely upon the reasonableness of the local rate, which is added to the terminal rate. Obviously, no rate to an intermediate point constructed under those conditions and on that principle can reasonably be higher than the sum of the terminal rate plus the local rate back.

However, the mere faet that a terminal point is situated on the water is not sufficient to excuse higher rates at intermediate points. The water competition must be real.

It must be noted that Section 4 provides that whenever a carrier in competition with a water route reduces the rate to or from the competitive points, it is not permitted to increase such rates unless, after hearing by the Commission, it is found that such proposed increase rests upon changed conditions other than the elimination of water competition. 


\section{SECTION 5}

Pooling of freight.-Section 5 provides that it shall be unlawful for any common carrier subject to the Act to enter into any contract, agreement, or combination with any other common carrier or carriers for the pooling $^{1}$ of freights of different and competing railroads, or to divide between them the aggregate or net proceeds of the earnings of such railroads, or any portion thereof; and in case of an agreement for the pooling of freights, each day of its continuance is a separate offense.

Panama Canal Act: Water carriers.-Section 5 also provides that after July 1, 1914, it shall be unlawful for any railroad company or other common carrier subject to the Act to own, lease, operate, control, or have any interest whatsoever (by stock ownership or otherwise, either directly, indirectly, through any holding company, or by stockholders or directors in common, or in any other manner) in any common carrier by water operated through the Panama Canal or elsewhere, with which such carrier does or may compete for traffic.

Jurisdiction is conferred on the Interstate Commerce Commission to determine questions of fact as to the competition or possibility of competition, after full hearing, on the application of any railroad company or other carrier. Such application may be filed for the purpose of determining whether any existing service is in violation of this section and pray for an order permitting the continuance of any vessel or vessels already in operation, or for the purpose of asking an order to install new

The dividing of business or revenues among carriers in accordance with agreements. 
service not in conflict with this provision. The Commission may, on its own motion or the application of any shipper, institute proceedings to inquire into the operation of any vessel in use by any railroad or other carrier which has not applied to the Commission and had the question of competition or the possibility of competition determined as herein provided. In all such cases the order of the Commission is to be final.

If the Interstate Commerce Commission shall be of the opinion that any such existing specified service by water other than through the Panama Canal is being operated in the interest of the public and is of advantage to the convenience and commerce of the people, and that such extension will not exclude, prevent, or reduce competition on the route by water under consideration, it may, by order, extend the time during which such service by water may continue to be operated beyond July 1 , 1914. In every case of such extension, the rates, schedules, and practices of such water carrier shall be filed with the Interstate Commerce Commission and shall be subject to the Act in the same manner and to the same extent as is the railroad or other common carrier controlling such water carrier or interested in any manner in its operation.

No vessel permitted to engage in the coastwise or foreign trade of the United States is permitted to enter or pass through the Canal if such ship is owned, chartered, operated, or controlled by any person or company which is doing business in violation of the Sherman Anti-Trust Act.

At the present time the Commission is considering the applications from various carriers which own ships and desire to be relieved from the application of this law. Many of the great trunk lines in the country are owners of large fleets of boats. The only competitor of 
the railroad is the water carrier. Therefore, the railroad, by owning the water carriers, can always be in a position to fight independent water lines and control the rates.

The opening of the Panama Canal is the greatest menace that the transcontinental railroads have to face. It cuts the voyage around Cape Horn in two and shortens the distance on the way from New York to San Francisco by over three thousand miles. It is predicted that the Canal will cause the transcontinental rates to decrease 40 per cent. 


\section{SECTION 6}

\section{Tariffs}

Jurisdiction of Commission.-Section $6^{1}$ provides that every carrier subject to the Act must file with the Interstate Commerce Commission and print and keep open for public inspection schedules showing all rates, fares, and charges for transportation between the different points on its own routes, and all different points on its own routes and those on the routes of any other carrier by railroad, pipe line, or waterway. When a through route has been established, if no joint rate over the through route has been fixed, the several carriers composing such through route shall file, print, and keep open for public inspection the separate charges for the through transportation.

It is further provided that the schedules must plainly state the places between which property and passengers are to be carried and must state storage and icing charges, and any other which the Commission may require. The schedules must also specify all privileges or facilities granted or allowed, and any rules or regulations that would affect or determine any part or the aggregate of such charges or the value of the service rendered to the passenger, shipper, or consignee. Such schedules should be plainly printed in large type and copies for the use of the public should be placed in every depot, station, and office of the carrier.

One of the most important sections of the whole Act is this one requiring the publishing of tariffs. Its effect

"Often referred to as the "publicity clause" of the Act. 
was to prevent the granting of secret rates. By compelling adherence to its provisions, every shipper knows the rate that every other shipper is supposed to pay. By forcing the carrier to charge the published rate, the giving of rebates became a thing of the past. The Supreme Court of the United States has held that this part of the Act is constitutional, inasmuch as Congress has the constitutional power to adopt the policy of requiring the sale of transportation by carriers only for cash at the published rates, and to prescribe appropriate means to give it effect. ${ }^{2}$

Publication: Effect.-The Act imposes upon common carriers subject to its provisions the duty of establishing in the prescribed manner the rates, whether individual or joint, to be charged for the transportation in interstate commerce of property over their lines. The rates so established are obligatory upon carrier and shipper, and must be strictly observed by both until changed in the mode prescribed. ${ }^{3}$

Rates filed and published as required become effective in not less than thirty days after filing, unless special permission is given by the Commission, before any transportation takes place thereunder. Rates duly published as required by the Act are absolutely binding upon carriers and shippers alike until lawfully changed as provided in the Act. This does not render ineffective the provision of Section 1, namely, that the Commission can substitute reasonable rates for the future, or the subsequent provision authorizing the Commission, upon proper showing, to award damages resulting on account of collecting unreasonable or unlawful rates in the past.

Adherence to published rate.-The duty of shippers to pay published rates is precisely the same as the duty of

I. \& N. R. R. v. Mottley, 219 U. S. 467.

U. S. v. Miller, 228 U. S. 599. 
the carriers to collect such rates. The fact that a charge is grossly unjust and unreasonable affords no excuse to the shipper, the carrier, or the Commission for disregarding the application of lawfully published and established tariffs. The law plainly provides for but one method of getting rid of the unreasonableness or unjustness of duly established rates, and that is by their condemnation upon complaint and investigation. They cannot lawfully be ignored without making the parties to such transactions incur the penalties of the law. In no other way could discriminations which have existed be prevented. In the enforcement of the statute in this respect, the Commission has no discretion.

A tariff cannot be varied from even if, in a particular case, it be to the interest of both the shipper and the railway that it be done. It is absolutely beyond the power of either a railroad company or a shipper to make a valid contract for a less rate than the published schedules filed with the Commission; and, notwithstanding a contract of this kind, the measure of liability of the shipper is the rate so published and filed.

Erroneous quotation by carrier. - A frequent cause of complaint is the erroneous quoting of rates by carriers' agents. Frequently, the shipper asks the railroad what the rate is between certain points. The carrier's clerk, either through error or an attempt to get the business, will quote a rate lower than the one actually in force. Under such circumstances the shipper has no redress but must pay the published rate even though the railroad has quoted a lower rate to him. The shipper is chargeable with notice of the published rate and must pay it in all instances. Under the recent amendment, however, the shipper may demand a written quotation of the rate; if the carrier quotes the wrong rate it is liable to a penalty of $\$ 250$. 
Necessity of publication.-To prevent discrimination and promote equality of treatment in charges and services, the law requires not only a definite statement of the amount of the rates, fares, and charges of carriers in their established schedules, but an equally definite statement therein of all privileges and facilities granted or allowed in connection therewith, ${ }^{4}$ and any rules or regulations which in any way affect or determine any part or the aggregate of the rates, fares, or charges, or the value of the service rendered to the passenger, shipper, or consignee. It is clear that no schedule complies with the requirements of the law which does not definitely and fully state the charges on the one hand, and the services to be rendered therefor on the other.

Purpose of publication.-The objects of the Act are to prevent favoritism and to secure equal rights to all in interstate transportation and to apply one legal rate published, posted, and accessible to all alike. ${ }^{5}$ The reader should always bear in mind this most important principle, and apply it as a test to all questions presented to him under the Act.

Posting.-Contrary to the general impression, the posting of rates is not essential to make them legally operative and is required only as a means of affording special facilities to the public for ascertaining the rates actually in force. Publication and posting within the meaning of the Act are essentially distinct. The publication intended by the Act consists in promulgating and distributing the tariff in printed form preparatory to putting it into effect, while the posting is a continuing act enjoined upon the carrier while the tariff remains operative as a means of affording special facilities to the public

'Some of the more important are transit, compression, concentration, elevation, switching, refrigeration, reconsignment, etc.

N. Y. C. \& H. R. R. R. Co. v. U. S., 212 U. S. 481. 
for ascertaining the rates in force. A tariff filed with the Commission in the manner prescribed by law and on statutory notice is lawfully binding upon both carriers and shippers even though it is not posted at stations fully thirty days prior to its effective date.

The Act provides that it is the duty of every carrier by railroad to keep at all times conspicuously posted in every station where freight is received for transportation the name of an agent resident in the city, village, or town where such station is located, to whom application may be made for the information required to be furnished on written request; and in case any carrier shall fail at any time to have such name so posted in any station, it shall be sufficient to mail such request addressed in substantially the following form: "The Station Agent of the ........ Company at ........ station," together with the name of the proper post-office. The name of the carrier company and of the station should be inserted in the blanks.

Construction.-A great many questions arise as to the meaning of certain tariffs. As a general rule, it may be said that tariffs are to be construed according to the reasonable construction of their language and not by the arbitrary practice or intention of the carrier. A tariff should not be ambiguous and uncertain, since it is not just or fair to the shipping public to promulgate as a basis for determining rates a tariff the terms of which are either wholly or partly indefinite or impracticable of application. Shippers must necessarily be more or less misled thereby, and any effort on the part of the carriers to apply the tariff by a lax interpretation thereof must result in inextricable confusion. The rate on an article of commerce should be plainly and clearly stated in terms that the shipping public may readily understand. In this connection the reader should 
consult Tariff Circular No. 18-A, which contains the Commission's rules on the subject. ${ }^{6}$

Through shipments.-Section 6 also provides that any common carrier subject to the Act receiving freight in the United States to be carried through a foreign country to any place in the United States shall similarly print and post for public inspection schedules showing the through rates established and charged by it to all points in the United States beyond the foreign country to which it accepts freight for shipment. Any freight shipped from the United States through a foreign country into the United States the through rate on which shall not have been made public, as required by the Act, shall, before it is admitted into the United States from such foreign country, be subject to customs duties as if it were of foreign production.

The same rule as applies to rates between specified points discussed heretofore also applies to rates that are used as part of a through rate. Thus, state rates not on file with the Commission are not a lawful factor in a combination through interstate charge. Very frequently, state rates are not required to be published by the state law. If the carrier desires to use such rates on interstate shipments it must publish and post them as required by the Act.

Section 6 also provides that no change shall be made in the rates, fares, and charges or joint rates, fares, and charges which have been filed and published by any common carrier in compliance with the requirements of Section 6, except after thirty days' notice to the Commission and to the public, published as provided. This notice shall plainly state the changes proposed to be made in the schedule then in force and the time when the

\footnotetext{
This publication is incorporated in "Publication and Filing of Tariff:"
} 
changes will go into effect; the proposed changes shall be shown by printing new schedules, or shall be plainly indicated upon the schedules in force at the time and kept open to public inspection; provided, the Commission may, in its discretion and for good cause shown, allow changes upon less than the notice specified, or modify the requirements of Section 6 in respect to publishing, posting, and filing of tariffs, either in particular instances or by a general order applicable to special circumstances. While the Act authorizes the Commission in its discretion and for good cause shown to permit changes in tariffs or fares on less than statutory notice, the Commission seeks to limit the exercise of this discretionary power to cases where actual emergency and real merit are shown. The power is not to be lightly regarded, and it will not be exercised to aid a carrier in any strategic endeavor or to aid shippers in any ordinary commercial exigency.

Since the Commission has no jurisdiction over ocean carriers, the "joint rate" referred to in Section 6 of the Act relating to the publishing of rates does not apply to the combined rates on shipments from United States inland points through seaports via ocean carriers to foreign points. To permit the making of joint rates, in the strict sense, between such points, would open the way for rebates and other discriminatory practices. This is due to the fact that in publishing a joint rate under Section 6 the carriers are not compelled to publish their divisions of the same, and hence, by a manipulation of divisions, the ocean carriers might obtain an inequitable portion thereof wherewith to "induce" traffic. On such traffic, therefore, the rail carriers must publish their rates from inland points to seaports.

Section 6 also provides that the names of the several carriers which are parties to any joint tariff shall be specified therein, and each of the parties thereto, other 
than the one filing the same, shall file with the Commission such evidence of concurrence therein or acceptance thereof as may be required or approved by the Commission. Where such evidence is filed it shall not be necessary for the carriers filing the same also to file copies of the tariffs in which they are named as parties. If a carrier publishes a tariff showing that it can make delivery on the tracks of a carrier from which it has not obtained concurrences, it is liable in damages for such erroneous publication. A carrier has no right to publish a through rate unless all the carriers over that route have concurred or under an order of the Commission compelling such publication and joint action.?

Special contracts.-Every common carrier subject to the Act must also file with the Commission copies of all contracts, agreements, or arrangements with other common carriers in relation to any traffic in which it participates which comes under the provisions of the Act.

The Act provides that the Commission may determine and prescribe the form in which the schedules to be kept open to public inspection shall be prepared and arranged, and that it may at its discretion change the form from time to time.

Section 6 also sets forth that, unless otherwise provided by the Act, no carrier shall engage or participate in the transportation of passengers or property, unless the rates, fares, and charges upon which the same are transported shall have been filed and published in accordance with the provisions of the Act; nor shall any carrier charge, demand, collect, or receive a greater or less or different compensation for such transportation of passengers or property, or for any service in connection therewith, between the points named in such tariffs than the

\footnotetext{
The different kinds of concurrences are explained in "Publication and Filing of Tariffe."
} 
rates, fares, and charges which are specified in the tariff filed and in effect at the time. Nor shall any carrier refund or remit in any manner or by any device any portion of the rates, fares, and charges so specified, or extend to any shipper or person any privileges or facilities in the transportation of passengers or property, except such as are specified in such tariffs.

In time of actual or threatened war, precedence shall, upon the demand of the President of the United States, be given, over all other traffic, to the transportation of troops and material of war, and carriers shall adopt every means within their control to facilitate and expedite the military traffic.

The Commission may reject and refuse to file any schedule tendered for filing that does not provide and give lawful notice of its effective date. Any schedule so rejected by the Commission is void and its use unlawful.

In case of failure or refusal on the part of any carrier, receiver, or trustee to comply with the terms of any regulation adopted and promulgated or any order made by the Commission under the provisions of Section 6, such carrier, receiver, or trustee shall be liable to a penalty of $\$ 500$ for each such offense, and $\$ 25$ for each and every day of the continuance of such offense, which shall accrue to the United States and may be recovered in a civil action brought by the United States.

If any common carrier subject to the provisions of this Act, which, after written request made upon the agent of such carrier, by any person or company, for a written statement of the rate applicable to a described shipment, shall refuse or omit to give such written statement within a reasonable time, or shall misstate in writing the applicable rate, such carrier is liable to a penalty of $\$ 250$, which shall accrue to the United States and may be recovered in a civil action brought by the United States; 
provided, the person or company making such request suffers damage in consequence of such refusal or omission or in consequence of the misstatement of the rate, either through making the shipment over a line or route for which the proper rate is higher than the rate over another available line or route, or through entering into any sale or other contract whereunder such person or company obligates himself or itself to make such shipment of freight at his or its cost.

The Panama Canal Act has also amended Section 6 to the effect that when property is transported from one point in the United States to another by rail and water through the Panama Canal or otherwise, the Interstate Commerce Commission shall have jurisdiction over such transportation and over the carriers, both by rail and by water. It is also given power to establish physical connection between the line of the rail carrier and the dock of the water carrier, by directing the rail carrier to make suitable connection between its line and tracks which may have been constructed from the docks to its right of way, or by directing either or both the rail and the water carrier to construct and connect with the railroad a spur track or tracks to the dock. The connection is only to be made where reasonably practicable and where the amount of business to be handled is sufficient to justify the outlay. The Commission is given full authority to determine the conditions upon which these connecting tracks shall be operated and what sum shall be paid either for the construction or operation. The Commission is also given power to establish through routes and joint rates between and over those of the rail-and-water lines and to establish maximum proportional rates by rail to and from the ports to which the traffic is brought or from which it is taken by the water carrier. It further provides that if any rail carrier enters into any arrange- 
ment with any water carrier operating from a port in the United States to a foreign country through the Panama Canal, or otherwise, for the handling of through business between interior points in the United States and such foreign country, the Interstate Commerce Commission may require such railway to enter into similar arrangements with any or all other steamships operating from such port to the same foreign country. 


\section{SECTION 7}

Continuous carriage.-Section 7 provides that it shall be unlawful for any common carrier by any means to prevent the carriage of freights from being continuous from the place of shipment to the place of destination. It further states that no break of bulk, stoppage, or interruption made by any carrier shall prevent the carriage of freights from being treated as one continuous carriage from the place of shipment to the place of destination, unless such break, stoppage, or interruption was made in good faith for some necessary purpose, and without any intent to avoid or interrupt unnecessarily such continuous carriage or to invade any of the provisions of the Act.

While the meaning of this section is probably entirely clear, it may assist in understanding it to suppose that a carrier might intentionally delay shipments for its own purposes. This section does not, of course, undertake to provide that necessary delays such as congestion of traffic, breakdowns of equipment, or other causes for delays may be considered as a violation of the Act. 


\section{SECTION 8}

Attorney's fees.-Section 8 provides that in case any carrier shall do, cause to be done, or permit to be done, any act, matter, or thing prohibited or declared to be unlawful, or shall omit to do any act, matter, or thing required to be done by the Act, such common carrier shall be liable to the person or persons injured for the full amount of damages sustained, together with a reasonable counsel or attorney's fee, to be fixed by the court in every case of recovery, which attorney's fee shall be taxed and collected as part of the costs in the case.

It has been held that this section of the Act is constitutional. The attorney's fee which is recoverable, however, must be incurred in an action brought in a court for violation of the Act. It cannot be recovered in an action before the Commission.

Neither can it be recovered in a court where the suit brought is to recover for loss or damage to goods. This is because the Act does not oblige carriers to carry safely. The fact that a carrier loses or damages goods is not a violation of the Act. 


\section{SECTION 9}

Actions at law.-Section 9 provides that any person or persons claiming to be damaged by any carrier subject to the Act either may make complaint to the Commission or may bring suit in any district court of the United States. They shall not, however, have the right to pursue both of such remedies. One of the two methods of procedure must be chosen.

Same subject: Witnesses.-The section further provides that in any such action brought for the recovery of damages, the court before which the same shall be pending may compel any director, officer, receiver, trustee, or agent of the corporation or company defendant in such suit to attend, appear, and testify in such case. It may also order the production of the books and papers of such party to any such suit; and the claim that any such testimony or evidence may tend to criminate the witness shall not excuse him from testifying. Such evidence or testimony, however, shall not be used against him in any criminal proceeding.

The Commission has no authority under the Act as amended to require witnesses to answer any question it chooses to ask in an investigation instituted by it for the purpose of discovering any facts tending to defeat the purpose of the Act, or for the purpose of recommending additional legislation relating to the regulation of commerce that it may conceive to be within the power of Congress to enact. The purposes for which it may exact evidence embrace only complaints for violations of the Act. 


\section{SECTION 10}

Penalties.-Section 10 provides that any common carrier, any director or officer thereof, or any receiver, trustee, lessee, agent, or person acting for or employed by it, who, alone or with any confederate, shall willfully do, permit, or cause to be done, anything prohibited by the Act, or who shall aid therein or omit to perform any duty required by the Act, or shall be guilty of any infraction of the Act for which no penalty is otherwise provided, shall be deemed guilty of a misdemeanor, and be subject to a fine not to exceed $\$ 5,000$ for each offense. If the offense for which any person shall be convicted shall be an unlawful discrimination in rates; fares, or charges for the transportation of passengers or property, in addition to the fine provided for, the offender shall be liable to imprisonment in the penitentiary for a term of not exceeding two years, or both such fine and imprisonment, in the discretion of the court.

The following are instances of criminal offenses under the Act. The Union Stock Yard \& Transit Company, Chicago, Illinois, made a contract with Pfaelzers \& Sons, packers, by which it agreed to pay the latter $\$ 50,000$ if they would build and maintain their plant adjacent to the yards of the Stock Yard Company. The only interest which the Stock Yard Company had in Pfaelzers \& Sons was the compensation for its service in handling their freight accruing to it through the Junction Railroad Company, which was owned by the same holding company as the Stock Yard Company. It was held that as the Stock Yard Company and the Junction Railroad Company were common carriers engaged in interstate 
commerce, the contract was illegal as charging less than the published rates and granting rebates in violation of Section 2 of the Interstate Commerce Act and Section 2 of the Elkins Act. ${ }^{1}$

It further provides that whenever anyone shall, by means of false billing, false classification, false weighing, or false report of weight, or by any other device or means, permit or secure transportation for property at less than the regular rates, it will constitute a misdemeanor punishable by a fine of not exceeding $\$ 5,000$, or imprisonment in the penitentiary for a term of not exceeding two years, or both.

A shipper as well as a carrier may be guilty of a criminal offense. Thus, defendant shipper made a contract with a carrier for the transportation of goods for export from Kansas City to New York City at the published rate. Shortly thereafter, the carrier raised its rates, and subsequent to this raise the shipper transported the goods to New York City at the rate contracted for. It was held that the shipper was guilty, under the Elkins Act, of the crime of receiving a rebate whereby property was transported at less than the published rate. If the shipper sees fit to make a contract covering a definite period for a rate in force at the time, he must be taken to have done so subject to the possible change of the published rate in the manner fixed by the statute, to which he must conform or suffer the penalty fixed by law. (Brewer J., dissenting.) ${ }^{2}$

Anyone who shall deliver property for transportation to any common carrier subject to the provisions of the Act, or for whom, as consignor or consignee, any such carrier shall transport property, who shall knowingly, by

${ }^{2} U$. S. v. Union Stock Yard \& Transit Co., 83 Sup. Ct. 83, 89.

Armour Packing Co. v. U. S., 209 U. S. 56, 82; 28 Sup. Ct. 428; 209 U. S. 90 ; 28 Sup. Ct. 439 ; 52 I. Ed. 698. 
false billing, etc., obtain transportation for less than the regular published rates applicable, shall be subject to a fine of not exceeding $\$ 5,000$, or imprisonment of not more than two years, or both.

There are a great variety of ways in which the shipper may be liable for violations of this section. A few examples will help to show how these attempts to defraud the legal rates may be brought about.

A shipper may describe an article which is provided with a first-class rate in such a way as to secure a fourth-class rate, and thus save the difference between the two rates. Shippers sometimes show the weight of the contents of packages rather than the weight of the contents plus the weight of the packages themselves. A very common form of attempt to defraud the carriers is by stating false weights on carloads. If a carrier depends upon the shipper's weight, the shipper may save the freight on a thousand pounds or more.

A number of prosecutions for these fraudulent practices have taken place within the last two years, very severe penalties having been imposed in some cases. 


\section{SECTION 11}

The Interstate Commerce Commission.-While Section 11 creates a commission to be known as the Interstate Commerce Commission, composed of five Commissioners, who shall be appointed by the President, by and with the advice and consent of the Senate, and this section has not been expressly repealed, under Section 24 the Commission is enlarged to seven members, no more than four of whom can be from the same political party.

Their terms, under Section 11, were for six years, but Section 24 makes their terms seven years. But any person chosen to fill a vacancy shall be appointed only for the unexpired time of the Commissioner whom he succeeds. Any Commissioner may be removed by the President for inefficiency, neglect of duty, or malfeasance in office.

No person in the employ of or holding any official relation to any common carrier subject to the provisions of the Act, or owning stock or bonds thereof, or who is in any manner pecuniarily interested therein, shall enter upon the duties of or hold such office. The Commissioners must not engage in any other business, vocation, or employment. No vacancy in the Commission shall impair the right of the remaining Commissioners to exercise all the powers of the Commission. 


\section{SECTION 12}

Powers of Commission.-Section 12 provides that the Commission shall have authority to inquire into the management of the business of all common carriers subject to the provisions of the Act, and shall keep itself informed as to the manner and method in which the same is conducted. It shall have the right to obtain from such common carriers full and complete information necessary to enable it to perform the duties and carry out the objects for which it was created.

Upon the request of the Commission, it is made the duty of any United States district attorney to whom the Commission may apply to institute and prosecute under the direction of the Attorney-General of the United States all necessary proceedings for the enforcement of the provisions of the Aat and for the punishment of all violations thereof. For the purpose of the Act the Commission is also given the power to require, by subpœna, the attendance and testimony of witnesses and the production of all books, papers, tariffs, contracts, agreements, and documents relating to any matter under investigation, from any place in the United States. 


\section{SECTION 13}

Parties to complaints.-Section 13 provides that any person, firm, corporation, company, or association, or any mercantile, agricultural, or manufacturing society, or other organization, or any body politic or municipal organization, or any common carrier, complaining of anything done or omitted to be done by any common carrier subject to the provisions of the Act, may apply to the Commission by petition, which shall briefly state the facts. Thereupon, a statement of the complaint so made must be forwarded by the Commission to such common carrier, who shall be called upon to satisfy the complaint, or to answer the same in writing, within a reasonable time specified by the Commission. If such common carrier within the time specified shall make reparation for the injury alleged to have been done, it shall be relieved of liability to the complainant only for the particular violation of law thus complained of. If it does not satisfy the complaint within the time specified, or there shall appear to be any reasonable ground for investigating the complaint, it shall be the duty of the Commission to investigate the matters complained of.

The Commission is also given power to investigate any complaint forwarded by the railroad commission of any state or territory alleging a violation of the Act, and also has full authority at any time to institute an inquiry, on its own motion, in any matter concerning which a complaint is authorized to be made, or concerning which any question may arise under any of the provisions of the Act, or relating to the enforcement of any of the provisions of the Act. The Commission has 
the same powers and authority to proceed with any inquiry instituted on its own motion as though it had been appealed to by complaint or petition under any of the provisions of the Act, including the power to make and enforce any order or orders or relating to the matter or thing concerning which the inquiry is had, excepting orders for the payment of money. An important provision is that no complaint can at any time be dismissed because of the absence of direct damage to the complainant. 


\section{SECTION 14}

Reports of the Commission.--Section 14 provides that whenever an investigation shall be made by the Commission, it is its duty to make a report in writing in respect thereto, which shall state its conclusions, together with its order in the matter.

The reports required by this section contain all the essential facts developed by the Commission from its investigation, and also its order as to how the conditions investigated are to be changed if it finds that a change is required. 


\section{SECTION 15}

Importance of Section 15.-This section is the dominating and controlling expression of the real object and meaning of the Act. It makes the Commission a special expert body to deal with rates and principles affecting rates, not a body to take the place of Congress. The Commission has no jurisdiction to say what shall be done as a matter of public policy except in so far as the public will almost always be considered in exercising its authority under the Act. Its duty with respect to rates is to inquire whether or not they are in accordance with the requirements of the Act.

The Commission, in passing upon the reasonableness or unreasonableness of a rate, acts as an administrative body having quasi-judicial ${ }^{1}$ functions. When it determines what the rate should have been and shall be in the future, it exercises certain legislative functions. When it computes the damages or reparation due the shipper by reason of the enforcement and collection of the rate, unreasonable to the extent that it exceeds a rate that is declared to be reasonable, there is a mere mathematical determination of the damages the shipper should receive. On account of the extreme importance of this section of the Act, the powers conferred by it will be examined in detail.

Section 15 provides that whenever, after full hearing upon a complaint made as provided in Section 13 of this Act, or after full hearing under an order for investigation and hearing made by the Commission on its own initia-

${ }^{2}$ Partly judicial. 
tive, it shall be of the opinion that any individual or joint rates or charges charged by any common carrier subject to the Act, or that any individual or joint classifications, regulations, or practices whatsoever, are unreasonable, unjustly discriminatory, or unduly preferential, it is empowered to determine and prescribe how the conditions are to be adjusted. It is also empowered to determine what individual or joint classification, regulation, or practice is just, fair, and reasonable, to be thereafter followed, and to make an order that the carrier or carriers shall discontinue such violation to the extent to which the Commission finds the same to exist.

All orders of the Commission, except orders for the payment of money, shall take effect within a reasonable time, not less than thirty days, and shall continue in force for such period of time, not exceeding two years, as shall be prescribed in the order of the Commission, unless the same be suspended, modified, or set aside by the Commission or by a court of competent jurisdiction.

The foregoing sections, which have been briefly summarized, deal with the general jurisdiction of the Commission and the procedure to be adopted in bringing cases to the attention of the Commission. There is no section of the Act more important than this, and the reader should give it close and careful attention. We will now proceed to consider it somewhat in detail.

It may be well to direct the attention of the reader to the fact that in reading the decisions he will often find references to the United States Commerce, circuit, and district courts. These courts, of equal jurisdiction, formerly existed, but the circuit and Commerce courts are now abolished, and all pending actions in them are transferred to the district court. 


\section{JuRisdiction of Comaission}

In general.-When a subject requires legislation for the regulation of future conduct, but the objects of the legislation are so many and of such different natures that they cannot be distinctly treated in the ordinary terms of legislative classification, it is not unusual to prescribe general rules, if such do not already exist, and delegate the power to apply those rules to the varying circumstances which may arise. The necessity of legislation in such form justifies its adoption and it is not obnoxious to the Constitution as a delegation of legislative power. Hence, the power's delegated to the Interstate Commerce Commission may be exercised, subject to the restrictions in the Act and in the Constitution. The outlook of the Commission and its porvers must comprehend all interests subject to the Act.

Primary jurisdiction.-The Interstate Commerce Commission alone has original jurisdiction to determine whether an existing rate schedule, an existing regulation or practice affecting rates, or an existing regulation or practice of any other kind affecting matters sought to be regulated by the Act, is unjust, unreasonable, unfairly discriminatory, or unduly prejudicial. Its jurisdiction is primary in matters of unjust discrimination, undue or unreasonable prejudice or disadvantage, and, generally, in all cases where the Commission may order the carrier to desist from violations of the Act. However, relief from excessive freight charges upon interstate shipments, where the charges are made according to established rates fixed and promulgated as required by the Interstate Commerce Act, must be sought only through the Commission. ${ }^{2}$

${ }^{2}$ A. T. \& S. F. Ry. Co. v. Superior Refining Co., 83 Kan. 732, 734; 112 P. 604. 
A United States district court has no jurisdiction to enjoin the putting into effect of a schedule of interstate rates without prior application to the Interstate Commerce Commission, because that body is vested with exclusive jurisdiction over questions of the reasonableness of interstate rates under tine Interstate Conmerce Act as amended. Under the provisions of the Interstate Commerce Act no court has any power, in the first instance, to inquire into the reasonableness of any rate that has been regularly established by a railway company and filed with the Interstate Commerce Commission and published by posting. The question of whether or not a rate is reasonable and just is one to be determined, in the first instance, in a proper proceeding before the Commission.

Thus, where the legal quality of the practice complained of is not definitely fixed by the Interstate Commerce Act, so that an allowance, otherwise permissible, is lawful or unlawful according as it is reasonable or unreasonable, an action by a shipper for damages, alleged to have arisen from the granting of the allowance to competitors, cannot be maintained in the courts until the Commission has passed upon the reasonableness or unreasonableness of such allowance. ${ }^{3}$

Although the Commission may have found in other cases, between other shippers and defendant carrier, that it is unlawful for carriers to require billing of shipments to ultimate destination in order to secure the benefit of through rates and transit privileges, a shipper seeking reparation for the violation of this ruling by a carrier must first apply to the Commission, as the case is not one of those which under Section 9 may be brought originally either before the Commission or the courts. ${ }^{4}$

${ }^{8}$ Mitchell Coal \& Coke Co. v. Penn. R. R. Co., 230 U. S. 247.

'National Pole Co. v. C. \& N. W. Ry. Co., 200 Fed. 185, 188. 
The design of the Act is not only to have the Commission pass primarily upon the questions involved in a particular rate or practice, but, as an administrative body, to pass upon all claims arising under such rate or practice, to the end that it, as such body, may make in each case appropriate order for reparation. The Act was intended by Congress to afford an effective and comprehensive means for redressing wrongs resulting from unjust discrimination and undue preferences by carriers.

It evinces a clear purpose to require shippers seeking reparation predicated upon the unreasonableness of a published rate primarily to invole redress through the Commission, which alone is vested with power to entertain original proceedings for the alteration of such established schedule, notwithstanding that Sections 9 and 22 of the Act seemingly give the aggrieved party the option of originally bringing suit in the clistrict court to recover damages for violation of the provisions of the Act. ${ }^{5}$

Finality of Commission's findings.-The orders of the Commission are final unless (1) beyond the power that it can constitutionally exercise, (2) beyond its statutory power, or (3) based upon a mistake of law. ${ }^{6}$

In decisions of the Commission questions of fact may be involved in the determination of questions of law, so that an order, regular on its face, may be set aside (1) if it appears that the rate is so low as to be confiscatory and in violation of the constitutional prohibition against taking property without due process of law, (2) if the Commission acts so arbitrarily and unjustly as to fix rates contrary to evidence or without evidence to support its decree, or (3) if the anthority therein involved has been 654.

${ }^{5}$ American Sugar Refining Co. v. D. L. \& W. Ry. Co., 200 Fed. 652,

${ }^{6}$ I. C. C. v. U. P. R. R. Co., 222 U. S. 541, 547; 32 Sup. Ct. 108; 56 L. Ed. 308. 
exercised in so unreasonable a manner as to cause it to be within the elementary rule that the substance, and not the shadow, determines the validity of the exercise of the power.

Neither is it for the Commerce Court to say whether the Commission has properly attached great or little weight to evidence adduced upon a given point, or whether the conclusion reached by the Commission upon testimony as to facts alone shows a mistake as to some particular fact not essential or vital to the proceeding, or an inadvertency, or is not such a conclusion as the Commerce Court might have reached. If the particular matter in issue and inquired into was one of fact and a full hearing was afforded and the conclusion reached is supported by substantial evidence, it will not be nullified by the courts. ${ }^{7}$

While the courts will not review the Commission's conclusion, holding rates unreasonable, by passing upon the credibility of witnesses or conflicts in testimony, the legal effect of evidence is a question of law, and an order based on no substantial evidence is contrary to law and must be set aside by the courts.

Orders of the Interstate Commerce Commission finding an allowance unreasonable or discriminatory, so far as they are administrative, are conclusive, whether they relate to past or present rates, and can be given general and uniform operation, since all shippers who have been or may be affected by the rate can take advantage of the ruling and avail themselves of the reparation order. They are quasi-judicial and only prima facie correct, in so far as they determine the fact and amount of damage. Since it involves the payment of money and the taking

'N. \& W. Ry. Co. v. U. S., 195 Fed. 953, 959. 
of property, the carrier is, by Section 16 of the Act, given its day in court and the right to a judicial hearing. ${ }^{8}$

In consideration of the question as to whether a single or individual rate is reasonable, the Commission may, among other things, consider the reports of the finances of the carrier, whose rates are the subject of investigation, and it may inquire into such reports and the items thereof, into circumstances of management, the carrier's present and prospective business, operating expenses, outstanding obligations, and interest charges, whether the rate under examination appears to be disproportionately or unreasonably high, and whether all traffic appears to bear a proper share of expenses and profits.

In a coal rate case there was evidence before the Commission as to the cost of transportation, operating expenses, interest, depreciation, other rates for transporting coal, markets, allowances, terminal expenses, the life of the carrier, and other conditions. It was held that the order reducing rates could not be held invalid on the ground of lack of evidence. ${ }^{9}$

Jurisdiction over procedure-Under Sections 12 and 15 , as we have seen, the Commission may make investigations to enable the Commission to perform its duty, and may inquire into the intrastate business of the carriers, where such inquiry is essential, to know the true condition of interstate business. ${ }^{10}$ This subject will be examined more in detail under Section 17.

Jurisdiction over orders.-The Commission has complete power to suspend or modify its orders. ${ }^{11}$

Jurisdiction over capitalization.-The Commission is without control over capitalization. It cannot place lim-

${ }^{\text {s} M i t c h e l l ~ C o a l ~ \& ~ C o k e ~ C o . ~ v . ~ P e n n . ~ R . ~ R . ~ C o ., ~} 33$ Sup. Ct. 916, 921; 230 U. S. 247.

${ }^{\circ}$ L. V. R. R. Co. v. U. S., 204 Fed. 986, 993.

${ }^{10}$ Goodrich Transit Co. v. I. C. C., 190 Fed. $943,965$.

"Loftus v. Pullman Co., 19 I. C. C. 102, 104. 
itation upon the purposes for which stocks or bonds may be issued, or designate what property they shall represent. ${ }^{12}$

Jurisdiction over interstate rates.-The making of a decision as to reasonableness of rates is peculiarly within the province of the Commission, and its findings are fortified by presumptions of trutl. ${ }^{13}$ Not only is the Commission vested with a discretion in determining the reasonableness of rates which cannot be disturbed, but it is entitled to select the testimony which it will believe and rely upon according as it addresses itself to its discriminating judgment. It may not condemn an existing rate whenever it is of the opinion that the same is unjust and unreasonable merely upon the expert knowledge and accumulated experience of its members, but may do so only upon a full hearing, at which the carrier is given an opportunity to be heard, and upon investigation by the Commission itself of the lawfulness of the rate in question and upon substantial evidence of record before it.

The Commission, in an investigation of rates, may bring to the solution of the question the accumulated experience and expert knowledge of its members, and it is its duty to do so. Before an existing rate may be condemned, however, there must be a finding that it is unjust and unreasonable, and this finding must be based upon evidence of which the carrier is apprised so that it may meet the case brought against it if it so desires. The courts will not interfere with the action of the Commission in fixing rates except upon the three grounds hereinbefore named. Congress did not, in the Act and its amendments, intend to vest administrative authority in the courts in the matter of fixing rates, but, on the contrary, committed the power to the

${ }^{12}$ Advances in Rates-Western Case, 20 I. C. C. 307, 334.

${ }^{23}$ I. C. C. v. C. R. I. \& P. Ry., 218 U. S. 88, 110. 
Commission and imposed on it the duty to ascertain facts, and, in view of such facts, to determine what is reasonable in regard to rates and charges. The fixing of the rates to be charged by public-service corporations is a legislative function, and when Congress, in the Act as amended June 29, 1906, confers upon the Interstate Commerce Commission the power to determine what are and what should be reasonable rates to be charged by the carriers of interstate commerce, its action in the premises is conclusive on the courts, subject to the limitations above named.

Under Section 15 of the Act, as amended by the Hepburn Act of June 29, 1906, the Commission has authority to order a railroad so to adjust its rates as to prevent discrimination against a shipper without prescribing the new rates to be applied or specifying how the charges should be equalized. Where there is a very considerable mass of testimony which is believed by the Commission to justify it in finding a rate umreasonable, and it appears that it has based its decision on such testimony, the condition precedent to the exercise of its power to fix reasonable rates has been met. Only the clearest evidence that the Commission has completely misconceived the testimony regarding rates, or willfully disregarded it, can sustain in court the charge of an arbitrary or unreasonable discharge of the statutory duties imposed upon it. ${ }^{14}$

Jurisdiction over intrastate rates.-The Commission has no authority over intrastate rates, although a local state rate that is a part of a combination interstate rate when applied to interstate commerce is within its jurisdiction. But it cannot order a reduction of intrastate rates; neither has it jurisdiction over a shipment moving

${ }^{14}$ A. T. \& S. F. Ry. Co. v. U. S., 203 Fed. 56, 59. 
from one point to another in the same state, although it was subsequently rebilled beyond the state.

For example, where cars in a movement from 'Traverse City, Michigan, to Horatio, Arkansas, are billed to Memphis, Tennessee, rebilled to Wynne, Arkansas, and there received by the shipper's agent and rebilled to Horatio, the Commission has no jurisdiction over the rate from Wymme to Horatio, the movement being intrastate. $^{15}$

However, a state commission has no right to compel such an adjustment of state rates as will discriminate against an interstate rate fabric. In this connection, the reader should refer to the discussion under Section 1, page 14.

Jurisdiction over suspension of rates.-Section 15 also provides that whenever there shall be filed with the Commission any schedule stating a new individual or joint rate, fare, or charge, or any new regulation or practice affecting any rate, fare, or charge, it shall have anthority at once, and if it so orders, without answer or other formal pleading by the interested carrier or carriers, but upon reasonable notice, to enter upon a hearing: concerning the propriety of the same. Pending the hearing and decision, the Commission, upon filing with such schedule and delivering to the carriers affected a statement in writing of its reasons, may suspend the operation of such schedule and defer the use of such rate, fare, charge, classification, regulation, or practice, but not for a longer period than one hundred and twenty days beyond the time when it would otherwise go into effect, unless it cannot complete its investigation in that time. In such case, six months longer may be taken.

The Commission is not empowered to suspend the operation of a schedule after it has gone into effect.

${ }^{16}$ Wells-Higman Co. v. St. L. I. M. \& S. Ry. Co., 18 I. C. C. $175,176$. 
Jurisdiction over unpublished rates:-Where a transportation service has been rendered for which no tariff authority whatever exists, and the shipper has paid the sum claimed by the carrier for that service, the Commission has jurisdiction to determine the reasonable charge for the service, and to order repayment of the amount in excess thereof collected by the carrier. ${ }^{16}$

Jurisdiction to award damages.-The Commission has no jurisdiction to award damages except such as constitute the difference between an unreasonable and a reasonable rate, or which result through discrimination or a violation of the Interstate Commerce Act in some particular. Depreciation of real estate values and loss of tenants are damages over which the Commission has no jurisdiction. The Commission has no jurisdiction to enforce the specific performance of a contract relating to switch comnections, or to award damages for its breach. The Commission has no authority to administer a remedy in applications for relief based solely upon a contractual relationship between the parties.

The Commission assumes no jurisdiction over such subjects as jolting, prompt settlement of damages, and polite treatment. A finding of general damages by the Commission would be mere opinion, not enforceable by the Commission or binding upon the courts, to which, in any event, resort must be had.

In a typical case, a Pittsburgh commission merchant charged defendant with having persistently delayed his carloads of fruit at yards where they were not accessible to teams and could not be unloaded, at the same time according to other shippers prompt service in placing cars at the unloading platform. Complainant asked damages in the sum of $\$ 30,497.70$ for loss entailed upon him

${ }^{1 e}$ Maxwell v. W. F. \& N. W. Ry. Co., 20 I. C. C. 197, 198; Goldenberg v. Clyde S. S. Co., 20 I. C. C. $527,528$. 
through demurrage, storage, the employment of additional help, and loss of trade, since the fruit reached him in a heated, withered condition. It was held that the Commission had no jurisdiction to award damages asked, the case being one for the courts; and that breaches of duty by a carrier, such as loss of or damage to property in transit and the failure to make delivery safely and with reasonable dispatch, in accordance with the contract, expressed or implied, which a carrier enters into when accepting a shipment, are matters solely within the jurisdiction of the courts.

The language of the Act being of doubtful interpretation, the Commission, which is a special tribunal of limited powers, ought not to take jurisdiction, but should resolve the doubt in favor of the court, where claims of loss and damage resulting from discrimination in use of facilities ordinarily belong. The question has been taken before the federal courts but the Supreme Court has not passed on it.

Jurisdiction over reasonable rates.-The Commission is expressly authorized to prescribe the just and reasonable maximum individual or joint rate or rates to be charged. In determining what is a reasonable rate as distinguished from a non-discriminatory rate, a great variety of matters must be considered by the Commission. A reasonable rate must be one which will afford to the carrier a just revenue for the service performed and at the same time impose no unjust burden upon the shipper.

Thus, among the elements considered by the Commission and the courts as being entitled to more or less weight may be mentioned the following:

The bona fide investment of the carrier, the car-mile or train-mile revenue produced by rates, comparison of the rate attacked with that in effect upon similar commodities, whether the rate is made under influence of 
competition or not, the cost of the service by the carrier, distance of the haul, equipment furnished, length of time the rate has been in effect, rate in the opposite direction, character of the traffic, revenue of the carrier, location of the road, permanent improvements made by the carrier, whether the carrier has had a previous haul on the raw material where the product shipped is a manufactured one, the profit of the shipper, the revenue of the carrier, risk of loss or damage to the shipment, size of the carrier, ton-mile revenue, number of carriers participating in the haul, value of the commodity, value of the service, volume of traffic, voluntary or subsequent reduction of the rate, weight of the shipment, relation of the rates.

It must be borne in mind that, in the opinion of the anthor, assuming the railroad to have been constructed through a territory in need of its facilities, it is entitled to earn from the aggregate of all its rates, when economically constructed and efficiently managed, a sum equal to 6 per cent upon its bona fide investment provided the rates so exacted do not place an unjust burden upon the public. The rights of the public are always paramount.

Jurisdiction over divisions. - Where more than one carrier engages in a haul, the rate received is divided among the participants by agreement. The amount which each one receives is called its "division" of the rate. These divisions are matter's of agreement between the carriers, and the public has no interest in them. If, however, the carriers cannot agree upon divisions, the Commission itself will fix them. It generally does so with reference to the length of the haul over each carrier, although sometimes a railroad may be so situated with respect to the traffic that it can demand a larger division than that to which it ordinarily would be entitled. 
Carriers, moreover, cannot, because of a dispute over divisions, cancel a through rate and thus cause an advance in charges to the shipper; nor because of such dispute can they refuse to establish a joint rate and through route where the same is reasonably necessary.

Small carriers, commonly called tap, or industrial, lines, varying in length up to 20 miles, often connect industries moving a large tonnage, particularly the lumber and steel interests with the trunk lines. For their service in hauling the product from the forest, lumber mill, or furnace to the trunk line and saving it that haul, these lines are given what are commonly called "divisions out of the rate." The right to receive these and the legality of the practice will be considered under the heading of "Allowances," inasmuch as such divisions are generally made for services other than the mere hauling of the shipment.

Jurisdiction over advanced rates: In general.-Section 15 provides that at any hearing involving a rate increased after January 1, 1910, or a rate sought to be increased after the passage of the Act, the burden of proof to show that the increased rate or proposed increased rate is just and reasonable shall be upon the common carrier. The Commission must give to the hearing and decision of such questions preference over all other questions pending before it, and must decide the same as speedily as possible.

This question of advanced rates is one of the most inportant subjects with which the Commission has to deal. A railroad has many different demands upon it. It must pay taxes, and this is a large item. It must constantly replace equipment, which, owing to the different state laws prescribing new and different appliances, is almost invariably more expensive than that formerly used. Bridges have to be repaired, culverts built, new tracks 
laid, new ties bought, and a thousand and one other things must be done.

The largest single item of expense, however, is that of wages, and these are constantly augmenting. Owing to the increasing amount of these various expenses, the railroads feel that they are from time to time entitled to higher rates.

The shipper, who is also subject to increased manufacturing costs, objects to paying higher freight rates. Hence, we have a constant conflict between the shipper and the consumer on the one hand and the railroad on the other. Formerly, when the railroad advanced its rates, neither the Interstate Commerce Commission nor the public had any remedy except by attacking the advanced rate the same as any other rate would be attacked. Finally, Congress amended the Interstate Commerce Act so as to provide that whenever an advanced rate was published to become effective, it could be temporarily suspended by the Commission and the carrier called upon to justify the advance. The burden of proof was placed upon the railroad. As we have seen, the Commission was also given power to suspend the advanced rate and to prevent it from becoming effective temporarily. On account of the importance of the subject, we will consider it somewhat more in detail.

The question of the reasonableness or the justness of the increase in interstate rates, is one for the Interstate Commerce Commission and not for the courts. The Commission is not concerned, however, with the motives of the carriers increasing the rates, provided the charges proposed are just and reasonable. It does not stand as a supreme traffic manager for the railroads of the country. Considerations of their policy is not a matter delegated to it. 
While the authority of the Commission extends only to passing upon the reasonableness of the rate presented for its consideration, it is not restricted to a single rate. Any number of rates may be attacked in the same complaint, and the duty of the Commission is to consider the passing upon those so presented. However, when there is involved the propriety of an advance affecting, for instance, the entire rate fabric within Official Classification Territory (consisting of one half the tonnage and one half the freight revenues of the whole country), and where that advance is justified mainly upon the ground, not of commercial conditions, but of lack of adequate revenue, on the present rate basis, the Commission must determine the fundamental question of the reasonableness of the rate and the adequacy of the carrier's revenues. ${ }^{17}$

However, it should be noted that the Commission has no authority to order the advance of a rate, although it may accomplish the same effect by prescribing that one point should take the same rates as another. Such an order can be made either by raising the rate to the favored point, or by reducing it to the other. In this connection, it must be remembered that the important question in many cases is not the amount of a rate, but its relation to other rates. In many cases of discrimination, there is no question as to the reasonableness of the rate in itself, but the complaint comes from the fact that the rate does not bear the proper relation to other rates.

Same subject: Justification of increase.-In all cases where the carrier increases an existing rate the burden of justifying such increase and of showing that the increased rate is reasonable is upon the carrier. It was at first contended that the statute only obligated the carrier to justify the increase in the rate, but it is now well set-

${ }^{17}$ Advances in Rates-Eastern Case, 20 I. C. C. 243, 248. 
tled that the carrier must show the entire increased rate to be reasonable. It is clear, from the language of the statute as well as from its history, that the purpose of Congress differed from the purpose of Parliament in that Congress did not intend to prescribe that any existing rates were necessarily reasonable, that is, that because they were then in effect they were not subject to attack; that it was the duty of the Commission to deal with the increased rates and not the increase in the rate; and that the Commission may continue in effect the present lower rates or may reduce the existing rates. ${ }^{18}$

It should also be noted that a group of carriers cannot cast upon a single carrier the responsibility of maintaining the burden of establishing the reasonableness of certain advances, and claim the benefit of whatever the case made by that carrier may establish.

Same subject: Right to advance rates.-Within certain limits it may be the right of the Commission to consider the question of advanced rates in Official Classification Territory as one of public policy and not one of strict legal right. If the true interest of the whole community requires it, the railroads might perhaps be allowed fair earnings with which to aid their properties in addition to the payment of return to their stockholders, even though there is no strict requirement of law which commands it. The ordinary considerations of justice require that money invested in railroads by invitation of the Government should be allowed a fair return. This does not mean that the Commission should permit rates which will guarantee all railroad investment, or which will guarantee any railroad investment at all times; but it should allow rates which will yield to this capital as large a return as it could have obtained from other investments of the same grade. If rates formerly in effect have be-

${ }^{18}$ Advances in Rates-Western Case, 20 I. C. C. $307,311,314$. 
come insufficient, then higher rates should be permitted. Rates should be such as to render possible a high-class, not an extravagant, transportation service. ${ }^{19}$

Varions reasons have been advanced to justify increased rates. We will note, briefly, the more common ones.

Very often carriers have advanced rates which are related in some way. It is now well settled that there is no justification for the increase in the fact that unless the rates to several communities are increased, another and competing community will be entitled to lower rates than it now enjoys. ${ }^{20}$ The fact that other rates may be reduced if the increases are not permitted affords no predicate that the present rates are unreasonably low.

Perhaps the most common excuse urged for an advance in rates is that the advance will equalize related rates. Rates between competing producing or consuming localities may be inequitably adjusted and an advance from the favored locality may be advisable. It is well settled, however, that merely because rates are increased so as to effect a differential, or so as more equitably to equalize rates between competing coal fields, it does not necessarily follow that the rates in themselves are just or reasonable. The Commission is not concerned with the increase in the rates, but with the increased rate. ${ }^{21}$ It should be noted, however, that advances proposed in order to bring about a proper relation of rates are justified.

Same subject: Right to earn.-As to what a railroad is entitled to earn, it seems that the trend of the highest judicial opinion is that the Commission should not accept the cost of reproduction, the capitalization, the prices of stock and bonds in the market, or yet the original invest-

${ }^{19}$ Advances in Rates-Eastern Case, 20 I. C. C. 243, 262.

${ }^{20}$ Texas Common Point Case, 26 I. C. C. 528, 532.

${ }^{21}$ Advances on Coal to Lake Points, 22 I. C. C. $604,612$. 
ment alone, as the test of present value for purposes of rate regulation. Perhaps the nearest approximation to the fair standard is that of bona fide inrestment-the sacrifice made $b y$ the owners of the property-considering as part of the investment any shortage of returns that there may be in the early years of enterprise. Upon the raluation thus reached, taling the life history of the road through a number of years, its promoters are entitled to a reasonable return. This, however, is manifestly limited, for a return should not be giren upon wastefulness, mismanagement, or poor judgment; and always there is present the restriction that no more than a reasonable rate shall be charged. There are mary elements that enter into this problem. Perhaps it may be suggested, as heretofore, that a road which has been economically constructed and is efficiently operated is entitled to earn 6 per cent on the bona fide investment in the property.

Same subject: Change in conditions.-One of the common excuses urged for an adrance in rates is the fact that conditions have changed since the establishment of the original rate. The reasonableness of a rate must of necessity depend upon the conditions surrounding the traffic at the time it moves. The length of the haul, the competition to be met, the cost and the value of the service, the density or volume of the tonnage, as well as the general transportation conditions then existing, are all factors that have a more or less definite relation to the rate that may reasonably be demanded. These factors, except possibly the length of the haul, the grades, and other transportation conditions, are in their nature neither permanent nor fixed, but they necessarily change with the general economic panorama. No presumption of law, therefore, can arise against an advanced rate simply because a lower rate previouslı existed. 
It is well understood that in recent years there has been a continuous advance in the price of most materials and supplies used in constructing and operating a railroad, that there has been a constant tendency to advance wages, and that all this has tended to increase the cost of operation. On the other hand, there has been a steady improvement in transportation efficiency. Trains are longer; cars are larger and more heavily loaded; grades are easier; the amount hauled by a given engine is greater; and the density of traffic is much larger. All this tends to reduce the expense of transportation.

These two sets of causes work in opposite directions and tend to balance each other. It is not certain what the net result has been at any time in the past, or what it is today. It is not improbable that at the outset the economies of operation more than outweighed the increased cost of labor and supplies, but that of late the reverse has been true.

But an increase in the cost of labor and in the price of railroad materials and supplies does not necessarily imply that there has been a decrease in the net earnings of the carrier during the same period. A material growth in its traffic and economies resulting from an alert and skillful management may readily overcome the increase in the cost of labor and its materials and thus leave its net revenues unimpaired.

Everything else remaining the same, an increase in cost of operation would justify an advance in rates. Other things remaining the same, increase in traffic requires a decrease in rates. It may, therefore, happen that the increase of traffic will more than offset the increase in operating expense.

Sometimes it happens that a low rate is established to meet competition which has ceased to exist. In such cases it is held that where former rates were forced down 
by past competition, the advanced rate will be sustained if it is not shown to be umeasonable per se. While a carrier may establish a lower rate to meet competitive conditions, and the Commission takes into account such conditions in passing upon the reasonableness of the rate adjustment, it does not follow that in a particular instance the Commission will condemn an advance of a rate which was formerly maintained to meet competition between different producing points. ${ }^{22}$

In the procedure of rate cases it is often of importance to ascertain just what proof should be submitted. Very frequently it happens that there are elements existing: which raise certain presumptions and therefore do away with the necessity of proof on those particular things. The most important one is the presumption that a rate voluntarily in effect for many years has been remunerative to the carrier. But this rule is subject to certain well-defined limitations.

Railways are authorized to establish in the first instance their transportation charges and the presumption of right-doing attaches to their acts in the establishment of those rates. The only presumption of law against a particular rate springs from the fact that the rate in question is an advance over some previous rate. The burden of proof is always upon the party who attacks the existing rate, except in the case of a rate advanced after January 1,1910 . The circumstance that the railway has for a series of years maintained a lower rate or a different relation of rates is a fact that may be introduced and considered like any other fact. ${ }^{23}$

But there is no presumption of wrong arising from the changing of a rate by a carrier. Undoubtedly, while

${ }^{22}$ Fla. Fruit \& Vegetable Ass'n v. A. C. L. R. R. Co., 17 I. C. C. B52, 558.

${ }^{23}$ I. C. C. v. Chicago G. W. R. R. Co., 209 U. S. 108, 119. 
rates are changed the carrier making the change must, when properly called upon, be able to give a good reason therefor. But the mere fact that a rate has been raised carries with it no presumption of wrong-doing.

Ordinarily, the advance of a rate for a short period followed by the restoration and maintenance of a lower rate formerly in force tends to raise a presumption of fact that the advanced rate was unreasonable. This rule may be rnodified where a special rate, not compensatory, is put in effect to "scalp" business on competitive traffic. ${ }^{24}$

The circumstance that carriers established and voluntarily maintained certain rates for twenty-five years, for instance, is not conclusive evidence that they were reasonable; but it is in the nature of an admission upon their part to that effect, which requires, when these rates are advanced, some satisfactory explanation. When it further appears that a rate voluntarily maintained for a quarter of a century has within seven years been increased by one fourth, the reason by which it is sought to justify a still further advance should be even more cogent. This does not conclusively show that the carriers ought not to be permitted to advance such rate at the present time or in the future; but it is evidence which bears strongly upon the propriety of a present increase.

The long continuance of a rate voluntarily established and not published under the compelling influence of competitive conditions is in itself evidence of no little weight of its reasonableness. But the long continuance of a rate largely loses its value as evidence in a case involving an advanced rate for the same service, when it is shown that the prior and lower rate was the result of the influence of a strong movement by water.

An advance in a long-established rate at once suggests the propriety of an inquiry of the carrier for a statement

"Fairmont Creamery Co. v. C. B. \& Q. R. R. Co., 22 I. C. C. $252,254$. 
of its reasons for making the advance. But in making its explanation the carrier is not under the necessity of overcoming the technical weight and force of a presumption of law that the previously existing lower rate was a reasonable rate. The long continuance of a lower rate may be said to raise a presumption of fact that the advanced rate is unreasonable. But this in a sense is no presumption at all, for it camnot carry beyond the actual tendency of the fact itself to produce that belief in the mind of the investigator. The fact that the lower rate has long remained undisturbed has strong probative value. Considered merely as evidence, such a rate history, in the absence of some explanation that satisfies the judgment of the propriety and need of an increase in rates, would ordinarily have a great force. But in every case the Commission must consider and weigh all the other facts of record before arriving at the conclusion that the increase in rates was unreasonable. ${ }^{25}$

Where carriers voluntarily maintain a rate between certain points for a long period of time, the presumption is that such rate is reasonable. Where a long-established rate is raised for a short period and then roluntarily reduced to the former level, the presumption is that the advanced rate was unreasonable; but this presumption may be overcome by proof to the contrary. However, where an advance is made in rates long maintained and the evidence shows that the traffic affected is large, important, and constantly increasing, the advance will be held unjust unless it is satisfactorily explained. ${ }^{26}$

Jurisdiction over through routes and joint rates.Section 15 also provides that the Commission may, after a hearing, either upon complaint or upon its own initia-

${ }^{25}$ Memphis Cotton Oil Co. v. I. C. R. R. Co., 17 I. C. C. $313,318$. 38.

${ }^{20}$ Pacific Coast Lumber Mfr's. Ass'n v. N. P. Ry. Co., 14 I. C. C. 23, 
tive, establish through routes and joint elassifications. Likewise, the Commission may establish joint rates as the maximum to be charged. Whenever the carriers themselves shall have refused or neglected to establish voluntarily through routes, joint classifications, or joint rates, it may prescribe the division of such rates, and the terms and conditions under which the through routes shall be operated. This provision applies when one of the connecting carriers is a water line.

The Commission may not, however, establish any through route, classification, or rate between street electric passenger railways not engaged in the general business of transporting freight in addition to their passenger and express business, and railroads of a different character; nor has it the right to establish any route, classification, rate, fare, or charge when the transportation is wholly by water.

In establishing such through route, the Commission shall not compel any company to embrace in such route substantially less than the entire length of its railroad plus that of any intermediate railroad operated in conjunction with or under a common management or control, and lying between the termini of such proposed through route. But if the observance of the foregoing rule would make the through route unreasonably long as compared with another possible and practicable through route, the Commission can force the railroad to establish the latter.

Under Section 1 the carrier is required to establish through routes and joint rates; and by Section 15 the Commission is given the authority to require the carrier to do this when necessary. There is no more important power than this conferred upon the Commission. 'Through routes and joint rates are of the utmost importance to the shippers. 
There are really only two limitations upon this power of the Commission. The most important is that the originating carrier is entitled to the long haul on the traffic and the Commission cannot deprive it of its right to have the freight carried over such part of its railroad as lies directly between the termini of the proposed through route, unless the carrier consents to the change, or unless to do so would make such through route unreasonably long as compared with another practicable through route which could otherwise be established.

It should be remembered that Section 1 of the Act relating to the establishment of through routes and reasonable rates applicable thereto, should be read in connection with the latter portion of Section 3, and with Section 15. Furthermore, regard should be given to the intendment of the Act as a whole, and the correction of the evil to be remedied. Prior to 1910, the power of the Commission to establish through routes was limited to instances in which no satisfactory through route existed. The removal of this limitation places within the discretion of the Commission the establishment of additional through rontes. The theory of the provision in Section 1 of the Act relating to the establishment of through routes and reasonable rates applicable thereto, is that carriers should freely interchange freight between their respective lines, to the end that interstate commerce may move without interruption or delay. The failure of the Commission to comply with its duty under Section 1 of the Act to establish just and reasonable rates does not nullify its compliance with the duty to establish through routes. It should be noted that under Section 1 of the Act, relating to the establishment of through routes and joint rates, the duty of the Commission is twofold: (1) Through 
routes must be established; (2) just and reasonable rates must be made applicable thereto. ${ }^{27}$

The important thing to remember is that the Commission has power to order the establishment of a through route and joint rate although there are in existence other through routes capable of adequately and expeditiously handling all traffic. We shall note briefly the general principles governing the subject of through routes and joint rates.

Same subject: Establishment by carrier.-It must be remembered that a through route is a continuous line formed by agreement, express or implied, between connecting carriers over which shipments are to be made and that all services in connection therewith from origin to destination must be performed by the carriers at their lawfully established rates applicable thereto. The service must be unbroken for every part of the journey over the continuous line. When a through route is established, the shipper should not be called upon at any point therein to assume possession or control of his shipment or to do any service in forwarding it to its final destination, such as loading and unloading in transit. But carriers may provide for unloading and transferring at stated junction points as a part of the through service, if their tariffs also specify the kind of service required in transferring at such points and the separate rates and charges to be exacted therefor. ${ }^{28}$

The Act imposes upon common carriers subject to its provisions the duty of establishing in a prescribed mode the rates, whether individual or joint, to be charged for the transportation in interstate commerce of property over their lines. The rates so established are obligatory upon carrier and shipper and must be strictly observed by

${ }^{27}$ Flour City S. S. Co. v. L. V. R. R. Co., 24 I. C. C. 179, 184.

${ }^{28}$ Memphis Freight Bur. v. F. S. \& W. R. R. Co., 13 I. C. C. 1, 8. 
both until changed in the required manner. The provision of Section 15 that the shipper shall in all instances have the right to determine over which of several competing lines his freight shall be transported, is not a flexible rule of law to be expanded or contracted to meet the needs of carriers under varying situations which may or may not be of their own creation, and the Commission has promulgated nothing in the nature of exceptions thereto or exemptions therefrom.

The law requires the establishment and maintenance of through routes and joint rates in order that traffic may be moved, whether in greater or less volume and for long or short distances, without the delays or other handicaps of reshipment. It recognizes the carrier's right to its own long haul; hence, it releases it from the obligation to participate in a through route between any two points which does not include all or substantially all of its line or lines between those points, except when an unreasonably long or circuitous route would otherwise be created. But it goes further; where through routes and through rates have been established, the law reposes in the shipper the right to dictate how his shipments must be routed, both as to terminal and to intermediate carriers.

Same subject: Right to favor own line.-Similarly, a carrier has a right so to construct its tariffs as to hold the business to its own line, provided in so doing any provision of the Act is not violated. A carrier may in its own interest, if it so desires, carry for a longer distance over its own line than would be necessary if carried over the line of its competitors, in order to obtain a portion of the competitive business upon terms that will afford some profit. It does not necessarily follow, however, that a carrier not competing for traffic in this way thereby subjects itself to an order compelling it to do so. Thus, a trunk-line carrier 
which purchases a branch-line road is justified in canceling through joint rates with another carrier when such cancellation will tend to move traffic entirely over its own line under reasonable and non-discriminatory rates, to the exclusion of the former two-line haul.

While a producing center may be entitled to the establishment of a through route and joint rate via a designated junction, it is not unreasonable, where the product is not perishable and moves at all seasons, to permit the originating carrier to transport such commodity via another junction point over a substantially longer route, in order to obtain the long haul and hold the traffic to its own line. But it must do so under rates which should be established via the shorter designated route. Inasmuch as a carrier may so construct tariffs as to hold traffic to its own line, so long as the Act is not violated, or may in its own interest carry for longer distance over its own line than would be necessary over the line of its competitor, as the end sought and the resulting rate in each distance is the same, the carrier may refrain from carrying the longer distance when to do so compels it to accept a less satisfactory division of the rate.

The carriers owe a duty to establish and maintain through routes and joint rates so that there may be the freest movement of traffic without the necessity of reshipment. In the formation of these through routes, however, the law recognizes the right of the carrier to protect its own long haul, and it may not be required against its own will to participate in a through route between any two points which does not include all, or substantially all, of its line or lines between those points, except when an unreasonably long or circuitous route would otherwise be established. ${ }^{29}$

\footnotetext{
${ }^{29}$ Chamber of Commerce of N. Y. v. N. Y. C. \& H. R. R. R. Co., 24 I. C. C.
} 
Same subject: What is satisfactory through route."Railroads of the country are called upon so to unite themselves that they will constitute one national system." They must establish through routes, keep these routes open and in operation, furnish necessary facilities for such transportation, and make reasonable and proper rules of practice as between themselves and the shippers, and as between each other. The purpose of Section 15 is to afford relief to a shipping community and not to aid carriers to acquire strategic advantages in their contests with each other. While a railroad company is competent to file a complaint under the clause in question and to demand an order establishing such routes and rates with its connections, its right to such relief is to be tested by the needs of the community that it seeks thus to serve and not by the fact that stations on its line in such community have not been accorded such routes and rates by connecting lines.

Points of production are entitled to reasonable through rates applicable thereto. Whether or not a through route shall be established by the Commission depends largely upon whether or not a through route via a designated junction point would be "unreasonably long" under the terms of Section 15.

Same subject: Right to withdraw through routes.Inasmuch as the through rate is generally less than the cornbination of local rates would be, there results an advance in rates to the shipper if the through rate is withdrawn. Very frequently, in order to force traffic through certain gateways or because of disputes with other carriers over divisions, railroads withdraw their consent to certain through routes. There is then presented the situation of an advance in rates that the carrier must justify. 
It has been held that a dispute over divisions, which is the most common excuse, affords no justification for the withdrawal. As a matter of fact, the carrier will have a very hard time justifying any such withdrawal unless there is left for the shipper another equally feasible and practicable through route and joint rate between the termini involved. If such a route does exist, then, subject to the other rules we have seen governing advances in rates, the carrier may be able to justify the withdrawal.

Same subject: Obligation to furnish equipment.Very often disputes arise between carriers and shippers as to what line in the through route is under the duty to furnish cars. The obligation to furnish cars for transportation over through routes composed of two or more carriers is a joint one, and rests upon all carriers participating in the route. Each carrier subject to the Act is charged with the duty of furnishing cars to industries located upon its line. In case of through routes, the obligation to furnish cars for shipments to points upon lines of its connections is joint with such connections. Generally speaking, however, in the first instance the duty of furnishing cars rests upon the originating carrier.

Same subject: Legal rate.-One other important thing to be remembered in the consideration of through routes is that the through rate is always the legal rate. It sometimes happens that between two termini a combination of local and other rates may be lower than the published through rate, and it is very common for shippers to insist that the lower rate should apply. It has been conclusively settled for many years, however, that the only legal rate that can apply is the through rate, and that shippers must pay this rate and carriers charge it, or a violation of the Act will result. But the amended 
fourth section makes unlawful a through rate that exceeds the sum of the intermediate rates.

Jurisdiction over routing and misrouting: In general.--Section 15 further provides that when a carrier is a party to tariffs carrying through routes and rates between two points the shipper between those points may specify over which route the shipment shall move. It is the duty of the initial carrier to route the property and issue a through bill of lading therefor, as directed, and to transport it over its own line or lines and deliver to a connecting line or lines according to such through route. It is the duty of each of all such connecting carriers to receive the property and transport it over its line and deliver the same to the next succeeding carrier or consignee, according to the routing instructions in the bill of lading.

We see, therefore, that Section 15 specifically gives the shipper the right to designate the routing of the shipment. There is perhaps no subject that has caused more trouble in the traffic field than the routing and misrouting of shipments. This subject is very important and should be studied somewhat in detail.

Where a carrier routes a shipment via a route that takes a higher charge than another available route, the Commission holds that through the wrongful act of the routing carrier the shipper has been compelled to pay a charge in excess of the reasonable rate via the cheaper route, and reparation will be awarded in the difference between said rates against the offending carrier.

Same subject: Carriers' duty to transport.-By far the greater number of controversies concerning routing arise in cases where the shipper did not designate it. It is, therefore, important to note what the obligations of the carrier are as to routing in the absence of shipper's instructions. 
Same subject: Accustomed or natural route.-Very often traffic moves naturally over a certain route. This is sometimes because the originating carrier itself has not the equipment and so must obtain it from a connecting carrier, which naturally insists that the traffic should move over its line. There may also be other reasons.

If a foreign car is available, which under rules as to car service must be sent via a particular line or route, over which a higher rate obtains, the agent must explain that fact to the shipper and allow him to elect whether he will use that car at the higher rate or wait for another car. If the shipper elects to use the car at the higher rate, the agent should so note on the bill of lading. When this rule is not complied with, the carrier is liable for misrouting. However, whatever weight may attach to what carriers may in their own best interest regard as "natural routes," it cannot overbalance the right of consignors to ship at reasonable and just rates over the lines of such carriers.

Same subject: Cheapest available route.-The rule, however, is best stated to be that in the absence of shipping instructions it is the duty of the originating carrier to ship via the cheapest available route.

Same subject: Conflict in billing between rate and route.-Very often shippers, in making out bills of lading, designate a certain route and a certain rate, but the rate stated does not apply via the route indicated. Where the shipper's bill of lading contains instructions both as to route and rate, and the rate is not applicable over any route of the receiving carrier, but is applicable over the route of a rival carrier to which the shipments might have been delivered, the receiving carrier may forward the shipment over its own line at the lowest rate law- 
fully applicable. It is not obliged to turn the traffic over to its competitor.

Where a shipper has written specific routing instructions in the bill of lading, and also inserted a rate which does not apply over the route specified, it is the duty of the initial carrier to ascertain which route the shipper wishes used. ${ }^{30}$ This rule does not apply, however, so as to charge the initial carrier with misrouting where it fails to turn over the shipments to a competing carrier with a lower rate.

Where a shipping ticket and bill of lading are both executed by a consignor, it is commonly the custom for the shipping ticket to be made out in accordance with the tendering of the shipment to the carrier. In order promptly to get the shipment under way, the carrier relies upon the instructions of the shipper, as shown in the ticket in executing its waybill. This custom operates to the advantage of the shipper in securing prompt transportation and benefits the carrier and the public in preventing the terminal congestion and undue detention of equipment.

Same subject: Shipper's instructions.-A shipper may offer his freight without routing instructions, in which event it is the duty of the carrier to route it via the cheapest available practicable route. But the shipper is also entitled, when for any reason he specifies a particular route, to have his shipments move in accordance with his instructions, at the established rate over that route. It is the duty of the initial carrier to take the necessary steps to carry out his routing instructions. Any carrier misrouting a shipment in violation of specific instructions to the injury of the shipper violates the Act and is responsible for the damage thereby caused to the shipper.

${ }^{80}$ Conference Ruling 286 (f). 
So where carriers literally observe the instructions given for routing, when the shipment is reconsigned, and send the shipment via the route designated, and apply the through rate over such route, the carrier cannot be held responsible for misrouting because it did not send the shipment via a cheaper available route. Where the shipper desires to prescribe the route over which his property shall be transported, all of his instructions in that respect should be placed upon the shipping order given to the carrier as well as upon the bill of lading signed by the carrier and retained by the shipper. In instances where the bills of lading and shipping orders are prepared by the shipper, and the shipper notes upon the bill of lading certain instructions that he fails to note on the shipping order, the carrier cannot be held liable for misrouting if it complies with the instructions on the shipping order.

Same subject: Liability for misrouting.-Where routing instructions are given under which more than one route may be selected by the carriers, the presumption. is that the lowest rate will be applied by them. The burden is upon the carrier charged with misrouting to show that it applied such rate.

Larger lines and systems, when they are intermediate. or connecting carriers, not infrequently relieve small initial carriers of the responsibility for correct routing, and from the nature of their larger traffic and wider opportunities for knowing what are the reasonably direct routes, they ought in many cases to be willing to do this. With respect to shipments to distant and unusual points, it is not reasonable to expect that the initial line, and often even its immediate connections, will be able to give specific routing, through to destination; in such cases, they ought not to be held to any greater duty than that of indicating the proper or usual gateway to destination. 
Carriers at fault in misrouting are liable for damages represented by higher charges than would have been lawfully assessable had the misrouting not occurred. In this case, liability is not limited to such damage as could reasonably have been anticipated, since a shipper cannot be deprived through a carrier's negligence of any lawful privilege offered by another carrier, especially after due diligence on his part to secure such advantage.

Jurisdiction over electric lines.-Section 15, as we have seen, provides that the Commission shall not establish through routes with electric lines not engaged in the general business of carrying freight in addition to their passenger and express business. Electric railways are common carriers by railroad, within the meaning of the Act, to the above extent, and when engaged in interstate commerce are subject to the jurisdiction of the Commission. Naturally, when subject to the law it has the right to obtain the benefits of that law.

The public, while it should not attempt to protect itself against combination by rail in so far as to prevent good and economical service, may well protect itself against the control of trolley lines and the prevention of competition in that field. Still, competition is not destructive of railroad business, proper; certain kinds of business can be done to better advantage by the trolley than by the steam road, just exactly as certain other kinds ought to go by water rather than by rail. Public interest requires that these three forms of transportation should be kept distinct, so that each may operate in its own sphere.

This applies to trolley lines that are of reasonable importance in competition against steam lines. It does not apply to those lines which may be constructed by a steam railroad in the extension or completion of its own system, as the kind of motive power is not significant. A branch 
line, proper, may as well be operated by electricity as by steam, and no reason is obvious why the building of such branch lines ought not to be in every legitimate way encouraged.

Jurisdiction over business secrets.-Section 15 provides that it shall be unlawful for any carrier or any officer, agent, or employe of such common carrier, or for any other person or corporation lawfully authorized by such common carrier to receive information therefrom, knowingly to disclose to, or permit to be acquired by, any person or corporation other than the shipper or consignee, without the consent of such shipper or consignee, any information concerning the nature, kind, quantity, destination, consignee, or routing of any property tendered or delivered to such common carrier for interstate transportation, which information may be used to the detriment or prejudice of such shipper or consignee, or which may improperly disclose his business transactions to a competitor. It is also unlawful for any person or corporation to solicit or knowingly receive any information that may be so used.

But information may be given in obedience to legal process, or by a carrier to another carrier or its duly authorized agent, for the purpose of adjusting mutual traffic accounts in the ordinary course of business.

This particular provision has cansed considerable readjustments of those arrangements under which certain large shippers operated facilities of the railroad, such as terminals, cars, and the like. It has been held that under Section 15 it is unlawful for a common earrier to disclose to the ultimate consignee the name of the original consignor of a shipment reconsigned in transit by the original consignee. As a typical case, it has been held that a shipper of salt does not have to deliver his shipments to a boat line controlled by competitor, and that 
such boat line, although it publishes rates on salt in cargo lots, cannot be considered a common carrier, but a private facility of the salt company by which it is owned. ${ }^{31}$

So where the tariff of a carrier provided that shippers of single cans of milk wished refrigeration, they should deliver their cans to competitors operating leased cars, who would charge certain prescribed rates. It was held that Section 15 of the Act clearly indicates an intent upon the part of Congress to secure to every shipper immunity from a disclosure of his business at the hands of a common carrier, and the rule referred to was unlawful. ${ }^{32}$

Arbuckle Bros. operate, at New York City, their own property as the Jay Street Terminal of defendants. Complainant is a competitor of Arbuckle Bros. To meet its complaint of unjust discrimination defendants offered to receive the sugar of complainant at the Jay Street Terminal. It was held that to offer complainant a receiving station on the dock of powerful competitors where its shipments would be handled and billed out by its competitors, thus exposing to them the names of complainants' customers, its markets, and the course of its business, is a suggestion that overlooks the duty of impartial service by defendants to all their shipping public. It violates the Act as amended, which makes it unlawful for an interstate carrier to "disclose his business transactions to competitors." 33

Jurisdiction over water carriers: Discrimination and rebates.-Very often carriers as well as shippers use boat lines as a method of getting lower rates or to discriminate against competitive shipments or lines. Several principles have been evolved governing situations of this character.

\footnotetext{
${ }^{31}$ Colonial Salt Co. v. M. I. \& I. Line, 23 I. C. C. $358,366$.

${ }^{82}$ Albree v. B. \& M. R. R. Co., 22 I. C. C. 303, 321.

${ }^{83}$ Federal Sugar Refining Co. v. B. \& O. R. R. Co., 20 I. C. C. 200,
} 211. 
A boat line incorporated as a common carrier obtained its facilities from a salt company by which it was owned and in whose interest it was operated; it published no rates except upon salt in cargo lots; its rates were manipulated for the benefit of the salt company by whose agents and employes all shipments had to be handled. It was held that the boat line was a mere device to defraud the law, and payments made to it by connecting rail carriers in the guise of divisions are rebates. But a railroad line has the right to reserve for certain boat lines certain of its water terminals, provided such reservations do not effect discrimination against traffic destined to such waterside terminals and to be carried therefrom by other boat lines. ${ }^{34}$

It is illegal discrimination for a rail carrier to refuse to issue through bills of lading, except as to certain preferred water carriers. A railroad may not have a preferred line of steamships to the exclusion of other ships. But a railroad has the right to reserve wharves for its own use and for the use of such water carriers as it prefers, provided it affords, to the public, access to equal facilities elsewhere at equal rates. Free wharfage, however, is a legitimate means of making a port attractive to ocean lines, and parties interested in pursuing that policy will be protected against coercion by carriers.

A water port is entitled to whatever advantage it can obtain through transportation by water, but its location does not entitle it to lower rates by rail. Although such preference may lawfully be accorded by a carrier in the protection of its own interests, it should not be acquired except in cases where manifest wrong would otherwise result. Nevertheless, the Commission does favor the existence of lower rates at ports put into effect by rail car-

\footnotetext{
427.

${ }^{84}$ Mobile Chamber of Commerce v. M. \& O. R. R. Co., 23 I. C. C. 417,
} 
riers to meet water competition. A rail carrier may control or conmect with a line of steamships engaged in foreign commerce, with which it may interchange business as freely as with another rail carrier; and it may quote a combined rate for the through movement, the railroad company acting as the agent of the steamship company in so doing. An inland carrier may go into the foreign shipping business without contravening any provision of the Act; nor is there anything in such statute which denies to a rail carrier the right to quote a rate from an inland point to a foreign destination over its own through route or any other route. But with such carriers, engaged in foreign business, the rail carrier has, so far as this law is concerned, a purely contractual or proprietary relation - not a relation related or controlled in any manner by this Act.

On foreign commerce the rate to be published with the Commission should be the rate to the port and from the port-an open rate, which anyone who desires to do so may use with equal advantage. The publication of such rate does not in any manner limit the very valuable privilege of through billing. Such through billing should clearly separate the liability of the rail and the ocean carrier, and show the published rate of the inland carrier. The routing of the freight, however, should remain with the shipper, and upon him may be imposed no greater charge to the port when his freight goes by one ocean line than by another. ${ }^{35}$

Jurisdiction over allowances: In general.-Section 15 also provides that if the owner of property transported under the Act directly or indirectly renders any service connected with such transportation, or furnishes any instrumentality used therein, the charge and allow-

${ }^{85}$ Cosmopolitan Shipping Co. v. Hamburg-American Packet Co., 13 I. C. C. $266,281$. 
ance therefor shall be no more than is just and reasonable; and the Commission may, after hearing on a complaint or on its own initiative, determine what is a reasonable charge as the maximum to be paid by the carrier or carriers for the services so rendered, or for the use of the instrumentality so furnished, and may fix the same by appropriate order. Section 15, therefore, gives the Commission the right to fix allowance where the shipper renders any service connected with the transportation, that is, a service which the railroad ought to perform.

Very often shippers perform certain services, such as the compression of cotton, repairing of cars, elevation of grain, lighterage, staking, transfer and the like, which it is the duty of carriers to perform. For various reasons the latter do not desire to do this, but prefer the shipper to do it and pay him what is called an allowance for the performance of such service.

These allowances have in the past been productive of a great deal of harm, as they have been the source of rebating. Large shippers, such as the steel mills, for instance, with an exhaustive system of switching cars among the various furnaces composing their plant, force an allowance from the carrier for this service, claiming that it is the duty of the carriers to deliver or take away the cars at the mouth of the furnace or at certain specified points. The lumber mills operating logging roads have forced allowances from the carriers by claiming that it was their duty to set in or take the cars from the forest. The tonnage of these shippers is generally so large that the railroad cannot afford to antagonize them by refusing to grant such allowances. Indeed, there has been generally so much competition to obtain this tonnage that some one carrier would generally be only too willing to pay the allowances to get the business. Hence, what one will do, all are compelled to do. 
In many instances the Commission has held such allowances to be illegal, and has ordered the railroads to discontinue making them. This is a subject of such importance in the traffic field that it will be considered somewhat in detail.

The Commission has jurisdiction over allowances made by carriers to shippers as performing a transportation service. Elevation of grain, for instance, is made such a part of transportation as to bring it within the jurisdietion of the Commission, which is authorized to determine what is a reasonable allowance to the shipper for such service.

Treatment of grain in the elevators, the cleaning, clipping, mixing, inspecting, and grading of it, are trade services; they do not pertain to transportation. No power had ever been granted to the Interstate Commerce Commission to regulate, to prohibit, to separate from the service of elevation and transfer in transit or from any other transportation service or to interfere with this transportation service. The Commission, however, has no power to forbid carriers from paying or allowing, for the elevation and transfer of grain in transit, reasonable compensation, merely because there is a possibility of a future violation of the law arising out of such allowances. But the Commission has the power to limit and prescribe the amount that a carrier may pay a shipper for the performance of a part of the carrier's duty and service in connection with the transportation of his freight.

Same subject: Discrimination.-A carrier is not warranted, under Section 15 , in making an allowance to a shipper who provides a facility and performs a service in the transportation of his own property, while refusing a similar allowance to another and competing shipper who provides a similar facility and performs the same 
service, in the transportation of his property. No violation of the Act can be predicated solely upon the fact that a carrier makes with one independent company a contract more favorable than with another for a service which that carrier is bound or undertakes to perform. The Act deals only with the obligation of carriers as carriers, and in no way attempts to regulate or interfere with matters involving their duties to shippers or passengers as such. Compression of cotton, for instance, is a service which the carrier procures for its own convenience; and when that service is performed in such a manner as not to prejudice or prefer a particular shipper or community, the Act does not limit the freedom of the carrier in making contracts ivith respect thereto.

Same subject: Specific allowances.-Allowances are often made in comnection with the handling of specific commodities and some of these specific allowances are treated herewith.

Compression of cotton.-Carriers have the right to compress cotton in transit. They also have the right to grant or allow to shippers or owners of cotton the privilege to concentrate uncompressed cotton at designated compresses on their lines for such treatment as the shipper's or owners may desire to give it, with the right of the shippers or owners, or deliver the cotton back to the carriers for transportation to interstate or foreign destinations at the through rates from point of origin. Whatever charges are made must, however, be just, reasonable, and non-discriminatory. They may not pay to compress companies any unjust or unreasonable charges.

Cooperage and grain doors.-In a typical case, complainants asked that defendant be required to provide by published rule that shippers of grain may, when occasion makes it necessary, cooper the car that is furnished, and recover therefor an allowance not to exceed $\$ 5$, including 
an allowance for grain doors. It appeared that shippers of grain from Washington and Oregon were furnished cracked and old box cars by defendant for the carrying of grain, which they repair themselves in order to save delay. It was held that it is the primary duty of a railroad to furnish equipment that is usable, and in the event that the car furnished is unfit, the shipper should reject it and call for another.

Allowances of the kind requested are of a dangerous character. The carrier cannot tell what the actual amount of material and labor used by the shippers was. The car is loaded immediately upon being repaired and is sent to some far distant point. There are no means of adequately checking the expenditure of the shipper, so that it becomes extremely easy to turn such allowances into real rebates. It is a safer and more reasonable practice to curtail such allowances than to extend them, since the Commission cannot in any way police such repairs. It is a far wiser policy for the carriers to repair their own equipment than to farm it out to shippers. A rule of this character could not be limited to the repair of cars for a shipment in bulk of grain without establishing a precedent as to allowances for other commodities.

Elevation of grain.-Elevation of grain is a privilege for which allowances are frequently made. There are two kinds of elevation, one of which may be termed transportation elevation, consisting of the passing of the grain through an elevator for the purpose of transferring it from car to car and obtaining its weight. The other is commercial elevation. This involves various processes in the treatment of the grain itself, such as cleaning, mixing, clipping, drying, etc. The first sort of elevation is an incident to the transportation of the grain; the second, to the merchandising of the grain. ${ }^{36}$

${ }^{88}$ Elevation Allowances, 24 I. C. C. 197, 199. 
A carrier has no right, under the pretext of a transfer which it does not require, to furnish a grain dealer commercial elevation, or what amounts to the same thing, to pay an elevation allowance for the commercial elevation of his grain; and if it does so, it must accord the same privilege or make the same payment at another point. ${ }^{37}$

Moreover, it is extremely difficult to separate transportation elevation from commercial elevation. Both things are part of the same general process. It is impossible to separate the different items of expense and to say with confidence what belongs to transportation and what to commercial elevation. The Commission believes that the payment of all elevation allowances and the giving of all free elevation should be prolibited, for in no other way can discrimination be prevented. Every service of benefit to a shipper should be charged for at a reasonable sum, and no charge should be allowed one shipper over another. The Supreme Court of the United States has, however, decided that some sort of elevation allowances may be made.

Lighterage.-An interesting case is as follows: Arbuckle Bros. operated their warehouse and property at the foot of Bridge Street, Brooklyn, as the Jay Street Terminal of the certain carriers. For the use of the dock, and for their services in conducting it as a freight station and in floating and lightering shipments between the dock and the regular terminals of defendants in Jersey City, Arbuckle Bros. received from defendants allowances ranging from 3 to $4 \frac{1}{5}$ cents per 100 pounds on all merchandise passing through the terminal, whether inbound or outbound.

The floats and barges used in this service were owned by Arbuckle Bros., and all persons employed in the

\footnotetext{
srTraf. Bur. Merchants' Exchange v. C. B. \& Q. R. R. Co., 22 I. C. C. $496,503$.
} 
handling of freight on the water as well as on the dock were on the payrolls of that firm. Immediately adjoining the dock property, Arbuckle Bros. have erected a large sugar refining plant of their own. One third of the total tonnage handled through the dock, inbound or outbound, is sugar received or shipped by them. The other two thirds are merehandise received or shipped by the public generally. Complainant was a competitor of Arbuckle Bros., with its refinery located at Yonkers. It shipped its sugar by a private transportation agency to Pier 24 and from thence to the New Jersey terminals of defendants, the same terminals to which Arbuckle Bros. deliver. It had to pay 3 cents per 100 pounds for this service to the private agency it employs, and received no allowance from defendants.

It was held that when a carrier undertakes to have a terminal operated for it by the owner of the property and the owner happens also to be a large shipper over its line, the law reads into the agreement between the carrier and the owner the peremptory requirement that the arrangement shall not result in any undue and unjust discrimination against other shippers competing with the owner in the same line of business; and that the terms under which defendant carriers accept the sugar of Arbuckle Bros. at their regular stations west of the river, result in inequalities, preferences, and discrimination, and are unduly and unjustly prejudicial to the rights of the complainant as a shipper of sugar over the lines of defendants in competition with Arbuckle Bros. in the same markets. ${ }^{38}$

Same subject: Legality of allowances.-Allowances and divisions must have a proper relation to the service performed and be such in amount as not to effect a rebate

\footnotetext{
214.

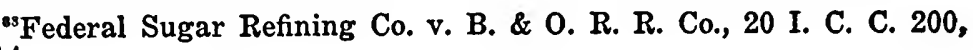


to the industry. Section 15 clearly implies that a just and reasonable allowance may be made to the owner of property transported when such owner renders a service connected with the transportation, or furnishes an instrumentality used in connection with it. It must be remembered that the delivery of goods to a carrier and the receiving of goods from a carrier are duties devolving upon the shipper, for which the carrier cannot be compelled to pay; and it is a violation of the Act for the latter to make allowances based upon the performance by shippers of services which shippers are legally bound to render for themselves. The fact that the rails, locomotives, and cars of an industry have been turned over to an incorporated railroad company, owned and operated by the industry or in its interest, does not divest those appliances of their character as a plant facility, if such in fact is the case. If the rails were laid and the equipment acquired for the use of the industry as a facility in the process of manufacture and production, and are so used, the fact that some outside traffic may be carried over the same rails does not modify the character of what is done over them for the industry. If in such a case the tracks and equipment are a facility of the plant and are so used in the process of manufacture, what is thus done for the controlling industry cannot be regarded as a service of transportation. It is clear that a division allowed by a public carrier out of the rate under such circumstances is a rebate to the industry. The test is: What is the real relation to the industry of the tap line? The common ownership of an industry and a short line serving it is not in itself sufficient to divest the railroad of its status as a common carrier.

In the matter of making allowances for services rendered in connection with transportation, the only services of the shipper that can be compensated for by the carrier 
under the Act are such as are rendered by the shipper after the carrier's duty to take and transport the goods has begun.

It is true that under Section 15 allowances are frequently made by a trunk line to an industry for services rendered by a line owned by the latter or its stockholders, as an instrumentality furnished by the shipper. But in such case the only concern of the Commission is to satisfy itself that the allowances are not above the reasonable cost of the service, and, therefore, are not indirectly a rebate of a part of the trunk line's charge to the owning industry, through the medium of the latter's railway.

Same subject: Plant facility.-The following cases iliustrate what services by the shipper are not the performance of a transportation service. Formerly, carriers delivered loaded cars to complainant's exchange tracks at Catasauqua. Complainant constructed tracks leading from the exchange tracks into its yards, and supplied locomotives to draw the loaded cars into its yards and to return loaded cars of its own products. Later, other industries grew up beyond complainant's plant, and complainant extended its tracks to such industries and charged them a stipulated price per car for moving cars to and from defendant's terminal. Said other industries were allowed compensation for the service that they secured from complainant. Subsequently, complainant incorporated its private railroad and demanded that defendants make it an allowance for hauling cars back and forth between complainant's yards and its team tracks.

It was held that the service was not one which defendants owed complainant a duty to perform; that defendants might properly allow to other industries compensation for the hauling of cars to their plants, since such 
service was merely the equivalent of the service rendered by defendants in placing the cars on complainant's exchange tracts; and that complainant was not entitled to compensation for the service rendered by its railroad, such service being in the nature of a plant facility. ${ }^{39}$

Complainant, General Electric Company of Schenectady, New York, filed a complaint against the New York Central \& Hudson River Railroad to determine its right to receive an allowance from defendant railroad for services performed by complainant in moving empty and loaded cars between the storage tracks and complainant's factories and shops. Its factory and shop yard occupies some 180 acres of land, and there were about 140 buildings. It had constructed 3 miles of storage together with connecting switch tracks of standard gauge, aggregating 12 miles in length and occupying some 23 acres of land; and in addition thereto had laid 7 miles of narrow gauge electric tracks crossing and recrossing the standard gauge system. The switch tracks leading to complainant's industries were from 400 to 500 feet long. Defendants had no right and under the circumstances it was impossible for them to make use of complainant's network of tracks, which was under the exclusive control of complainant. Complainant used its own locomotives and electric motors in moving loaded and unloaded cars in its yard, and performed about 112,000 carload movements a year. Defendants had been long accustomed to move cars free of charge between their tracks and factories of other shippers at Schenectady. For some 12 years defendants, under an agreement, had been allowing compensation for the service performed by complainant. It was held that defendants owed no duty to move the cars over complainant's network of tracks, and complainant was not entitled

${ }^{9}$ Crane Iron Works v. Central R. R. Co., 17 I. C. C. 514, 518-520. 
and could not be permitted to receive compensation therefor. ${ }^{40}$

It must not be considered, however, that all allowances to tap lines are rebates, merely because in certain instances the Supreme Court has specifically held that they are not.

Tap lines connecting timber districts and lumber mills with trunk lines are common carriers of proprietary as well as non-proprietary lumber. As such they are entitled to participate in joint rates, where the fact that the tracks are owned by the persons who also own the timber and mills that they principally serve is not shown to be inconsistent with the laws of the state in which they are organized and operated, lumber being excepted from the commodities clause. ${ }^{41}$

Lumber being excepted from the commodities clause, it was held, affirming the decision of the Commerce Court, that a tap line is entitled to the same allowance from a trunk line out of the joint through rate for logs and lumber offered the tap line by its proprietary company, that it receives out of the rate for non-proprietary logs and lumber. ${ }^{42}$

Same subject: Allowances as rebates.-If there is a holding out as a common carrier for hire, and if there is an ostensible and actual movement of traffic for the public for hire, the status of a common carrier exists, whether the holding out is by a company or by an individual. But such a holding out and the existence of an actual traffic are not conclusive in all cases. Where the holding out is in furtherance of the development of a plant facility and the alleged carrier is able to pick up some traffic

${ }^{\circ} \mathrm{G}$ Gen. Elec. Co. v. N. Y. C. \& H. R. R. R. Co., 14 I. C. C. 237,242 , $243,244$.

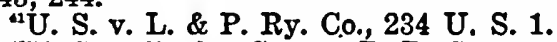

"U. S. v. Butler County R. R. Co., 234 U. S. 29. 
that is incidental to that purpose, it must be regarded simply as a cloak or device to effect unlawful results. ${ }^{43}$ The mere fact that a railroad is owned by a corporation which also owns the stock of the largest shipper over it, and that it was originally organized and built for the purpose of doing the work of that shipper, is not controlling against its being held a common carrier. But such a situation calls for the closest scrutiny of all charges and practices to ascertain whether there is undue discrimination through divisions of allowances that are the equivalent of rebates to the shipping owner. ${ }^{44}$

Same subject: Criminal liability.-It is important to note, in addition to the general principles which have been discussed, that there is a criminal liability under both the Interstate Commerce Act and the Elkins Act for the giving of rebates in the shape of allowances. This subject is discussed more in detail under Section 10, and in the treatment of the Elkins Act.

wap Line Case, 23 I. C. C. 277, 292.

${ }^{4}$ Crane R. R. Co. v. P. \& R. R. Co., 15 I. C. C. $248,252$. 


\section{SECTION 16}

\section{Reparation}

Jurisdiction of Commission.-Section 16 provides that if, after hearing on a complaint, the Commission shall determine that any party complainant is entitled to an award of damages under the provisions of the Act for a violation thereof, it shall make an order directing the carrier to pay to the complainant the sum to which he is entitled on or before a day named.

If the carrier does not comply with the order within the time limit specified, the complainant, or any person for whose benefit such order was made, may file in a United States court a petition setting forth briefly the causes for which he claims damages, and the order of the Commission in the premises. Such suit then proceeds in all respects like other civil suits for damages, except that on the trial the findings and order of the Commission are prima facie ${ }^{1}$ evidence of the facts therein stated, and except that the petitioner is not liable for costs either in the trial court or at any subsequent stage of the proceedings, unless they accrue upon his appeal. If the petitioner finally wins, he is allowed a reasonable attorney's fee, taxed and collected as a part of the costs of the suit. All complaints for the recovery of damages must be filed, however, with the Commission not later than two years from the time the cause of action accrues. A petition for the enforcement of an order for reparation must be filed in the court not later than one year from the date of the order.

${ }^{2}$ That is, they will be accepted without question. 
Under Section 16, the Commission is given the right to award damages for a violation of the Act. As this power is an important one and frequently invoked, it will be considered somewhat in detail.

Necessity of primary action by Commission.-Before a shipper can obtain redress for a violation of the Act, it is necessary that the Commission determine that the Act has been violated; it can then award damages. ${ }^{2}$ In giving the Commission jurisdiction over reparation, it was the manifest intent of Congress to provide shippers with a method of obtaining an award of damages other than by the expensive and tedious process of the law.

The Interstate Commerce Commission has power to determine the reasonableness of rates, and likewise is authorized to award reparation.

Where the rates charged were those which had been duly fixed by the carrier according to the Act, and had not been found to be unreasonable by the Interstate Commerce Commission, a shipper cannot maintain an action at law in the courts for excessive and unreasonable freight charges exacted on interstate shipments. But where the Commission finds the rate exacted to have been unreasonable, it may award as reparation the difference between that rate and the one which is reasonable, notwithstanding the former was the rate duly established by the carrier for the time being. ${ }^{3}$

The Act confers authority on the Commission to investigate complaints alleging unreasonable charges, and, after full hearing on formal complaint, to condemn such charges as are found to have been unreasonable, and to award reparation thereunder. ${ }^{4}$ The Commission is authorized to award reparation to any person or persons

"See "Procedure Before the Interstate Commerce Commission."

'Allen \& Co. v. C. M. \& St. P. Ry. Co., 16 I. C. C. 293, 295.

'Swift \& Co. v. C. \& A. R. R. Co., 16 I. C. C. 426,428 . 
found to be damaged through a violation of the Act by any common carrier subject to its provisions.

The jurisdiction and authority of the Commission is well settled in respect to its power to award damages where the published rate has been observed by the carrier, but such rate has been declared unreasonable. To hold that the publication of rates is conclusive of their reasonableness would go far toward defeating one of the leading purposes of the Act. ${ }^{5}$

Necessity and effect of finding of unreasonableness.Before the Commission can award damages for the exaction of an unreasonable rate it must make a finding that the rate is unreasonable.

The question as to whether or not rates are unreasonable or discriminatory is vitally related to all questions of reparation for their exaction. ${ }^{6}$

Where the Commission has found a rate unreasonable, it cannot deny reparation on shipments made prior to the filing of the complaint but within the limitation period on the ground that the shipper was guilty of laches ${ }^{7}$ in bringing the complaint, at the same time granting reparation on shipments made subsequent to the filing of the complaint. ${ }^{8}$

The Commission has no right to demand of the shipper, as a prerequisite to an order of reparation, "conclusive proof" of the unreasonableness in the past of the rate complained of, a preponderance of the credible evidence being sufficient. ${ }^{9}$

The Commission has authority to award reparation to a shipper from whom has been exacted a rate in excess of

${ }^{8}$ Nicola, Stone \& Myers Co. v. L. \& N. R. R. Co., 14 I. C. C. 199, 204. ${ }^{6}$ Phillips Co. v. G. T. W. Ry. Co., 195 Fed. 12, 18.

${ }^{7}$ A legal term meaning such an unreasonable delay in asserting an alleged right as should equitably debar the party.

${ }^{8}$ Russe \& Burgess v. I. C. C., 193 Fed. 678, 680; Thompson Lumber Co. v. I. C. C., 193 Fed. 682, 683.

${ }^{9}$ Thompson Lumber Co. v. I. C. C., 193 Fed. 682, 683. 
the lawfully published schedule rate, and this without a determination on its part that the rate exacted is unreasonable. ${ }^{10}$

It would be a manifestly harsh rule that would assume a rate now condemned as unreasonable to have been so for two years, or would fix the Statute of Limitations in the past as a basis for the payment of money by the carriers on past shipments, especially when no complaint had been made against them in that period. The law established no such presumption nor is it a necessary sequence that the rate has been unreasonable for any period in the past. Neither does it seem that the bona fide action of the carriers in the necessary exercise of their judgment within reasonable limits should always be at their peril-that they should be liable for reparation for the difference between rates initiated upon their judgment and those later changed upon the judgment of the Commission.

The awarding of reparation by no means necessarily follows the reduction of a rate, whether by the voluntary action of the carriers or by order of the Commission. Whatever may be the nature of the facts, circumstances, and conditions appearing in a particular case where reparation is involved, whether on account of excessive rates or unjust discrimination, there must be such degree of certainty and satisfactory conviction in the mind and judgment of the Commission as would be deemed necessary under the well-established principles of law as a basis for a judgment in court. ${ }^{11}$

When the Commission reduces a rate, it does not necessarily follow that it will award reparation on the basis of the new rate. There is no conclusive presumption that a

${ }^{10}$ C. B. \& Q. R. R. Co. v. Feintuch, 191 Fed. $482,486$.

${ }^{11}$ Anadarko Cotton Oil Co. v. A. T. \& S. F. R. R. Co., 20 I. C. C. 43 , 50,51 . 
rate reasonable today was reasonable a year before or a day before, since reasonable rates vary from time to time, and some point of division must be found. Where, therefore, rates have been established and maintained by the carriers in good faith, especially where they have been long in effect and acquiesced in by shippers without protest, the Commission will not award reparation even if the rate is reduced, unless it clearly appears that the rates paid in the past have been excessive. ${ }^{12}$

When the Commission reduces a rate and prescribes what will be the just and reasonable rate or rates to be thereafter observed in such a case as the maximum to be charged, it does not necessarily follow that for any length of time prior to the date of the opinion reparation will be awarded upon the basis of the rate so prescribed. ${ }^{13}$

The Act authorizes the Commission to condemn an unreasonable rate, to prescribe a rate to be applied in lieu thereof, and to award damages under the rate so condemned; but in all proceedings before the Commission, both formal and informal, the essential prerequisite to any award of damages is the condemnation of a rate, rule, or procedure that is made the basis of such award. ${ }^{\mathbf{1 4}}$

While the Act requires carriers to establish, file, and publish their rates, and commands their strict observance, such publication of rates is not conclusive of their reasonableness. It is the duty of the Commission to award reparation for duly proved damages to the parties injured by the exaction from them of unreasonable and unjust charges, notwithstanding such charges may be in accordance with the published rates. ${ }^{15}$

\footnotetext{
${ }^{12}$ Penrod Walnut \& Veneer Co. v. C. B. \& Q. R. R. Co., 15 I. C. C. $326,328$.

${ }^{18}$ Morse Produce Co. v. C. M. \& St. P. Ry. Co., 15 I. C. C. $334,338$.

${ }^{14}$ Pueblo Transportation Ass'n v. S. P. Co., 14 I. C. C. $82,84$.

${ }^{16}$ Nicola, Stone \& Myers Co. v. L. \& N. R. R. Co., 14 I. C. C. 199, 204.
} 
The Commission has no jurisdiction to make orders for reparation on account of any alleged excessive rate except when, upon complaint, notice to the defendants, and full hearing, such rate has been challenged and found to be unreasonable. ${ }^{16}$

Until the question of the reasonableness of the rates shall be determined, no orders for reparation will be entered on account of the alleged exaction of excessive charges on shipments from points of origin to destinations not involved in the former proceedings. ${ }^{17}$

Carriers are not entitled to resist an award of reparation for exactions made under a rate found to be unreasonable on the ground that the shippers were not themselves damaged, but simply added the excess to the selling price, thereby casting the damage upon the public. Wherever an unlawful and unreasonable rate is exacted, the shipper is entitled to reparation, without the tribunal's inquiring beyond the fact itself of the unreasonable exaction. ${ }^{18}$

Power to award tort damage.-While the Commission has power to award reparation for a violation of the Act, it has no power to award damages growing out of the carrier's default in some other respect. For instance, the Commission has no power to award damages for injury to shipments, because the Interstate Commerce Act does not compel the carrier safely to transport the goods. A few instances will be illustrative.

Depreciation of real estate values and loss of tenants on account of the discontinuance of a passenger station and train service thereat, are not such damages as are cognizable by the Commission. ${ }^{19}$

\footnotetext{
206.

${ }^{16}$ Nicola, Stone \& Myers Co. v. L. \& N. R. R. Co., 14 I. C. C. 199 , ${ }^{17}$ Nicola, Stone \& Myers Co. v. L. \& N. R. R. Co., 14 I. C. C. 199, 205.

${ }^{18}$ Burgess v. Transcontinental Freight Bur., 13 I. C. C. $668,679,680$.

${ }^{10}$ Mattison v. Penn. R. R. Co., 23 I. C. C. $233,235$.
} 
Complainant shipped by barge from Breveport, Mississippi, to Cincinnati, Ohio, a cargo of rough oak, gum, and cypress lumber. Upon arrival at Cincinnati, it was transferred into 37 cars, and charges based on a weight of 1,053,200 pounds were assessed. Complainant alleged that, owing to negligent handling at Cincinnati, the lumber when loaded into the cars was allowed to get wet and absorbed water to the extent of 148,723 pounds. At destination, complainant weighed dry 1,000 feet of each kind of lumber shipped, applied such weights to the respective aggregate number of feet in the cars, and obtained an estimated dry weight of 904,477 pounds. It asked reparation for the difference between such estimated dry weight and the billed weight. It was held that the Commission is without authority under the Act to award damages for negligence of the kind here alleged, such matters being within the jurisdiction of the courts. ${ }^{20}$

Neither are damages due to inability to compete in common market the subject of reparation. Damages such as decline in the market price of a commodity and lost commission for sale of such commodity due to the negligence of a carrier in not obeying reconsignment instructions, are not matters within the jurisdiction of the Commission. The Commission has no power to award damages to a shipper for loss of business and the cancellation of contracts of sale resulting from the granting by a carrier of an unjustly discriminatory rate to the shipper's competitor. In such a case, resort must be had to the courts. Since the Commission has no jurisdiction over loss and damage claims not arising from any duty imposed on the carrier by the Act, such as destruction of property from accident, loss by stealing or fire, etc., reparation should be refused for shrinkage in cattle due

\footnotetext{
${ }^{20}$ Buffalo Hardwood Lumber Co. v. B. \& O. R. R. Co., 21 I. C. C. 536,538 .
} 
to delay in shipment caused by washouts on the carrier's lines.

Right to recover and necessity of protest.-In a suit in the courts for damages against a carrier for unjust discrimination in granting rebates to a competing shipper, a protest by the plaintiff against the payment of charges assessed on his shipments is not prerequisite to recovery.

In view of the necessary relations between the carrier and shipper, many factors place the parties upon an unequal footing, so as to relieve the shipper from the necessity of protest against the payment of an unlawful rate. Some of these factors are: (1) The dependence in modern business life of the latter upon the former; (2) the right and duty of the carrier in the first instance to fix its charges; (3) its obligation to adhere to the same until it be altered in the manner prescribed by law; and (4) its right to enforce such charges by retaining possession of the freight transported, or to demand payment of the freight charges as a prerequisite to the transportation. Moreover, inasmuch as proceedings for reparation for damages before the Commission are purely statutory and correspond to actions at law in tort, ${ }^{21}$ the violation of the law produces the injury and completes the offense, so that the person injured does not have to perform any conditions to entitle him to recover for the damage sustained. For this reason protest upon payment of the unlawful rate is unnecessary.

Necessity of first paying tariff rate.-It is not the policy of the Commission to award reparation where lawful charges have not been paid. Hence, before bringing any complaint to the attention of the Commission, it is advisable that all the freight charges be paid first.

${ }^{21} \mathrm{~A}$ tort is a private wrong. Actions in tort are for injuries sustained through wrongful act other than breach of contract. 
Parties entitled to recover.-Unless reparation was claimed in the complaint upon which such decision was based, or was awarded by the Commission, claims for reparation based upon a decision of the Commission filed by complainants not parties to the case in which such decision was rendered will not ordinarily be allowed. The Commission may, however, in the exercise of its discretion, upon good cause shown, and under unusual circumstances, specially consider a particular claim for reparation of this class.

The court cases holding that either the consignor or the consignee may sue in case of loss or damage or breach of the contract of affreightment, mean that each has a beneficial interest to the extent of making either of them a proper party plaintiff in such proceeding. These cases do not in any way controvert the principle announced by the Commission-that the party paying the excessive charge is the one entitled to an award of reparation on finding that the rate charged is unreasonable and therefore unlawful.

The well-settled rule of the Commission is that the party who has been required to pay an unlawful rate is the party to whom reparation should be awarded. The person who handles produce on consignment is not entitled to it.

In any given case, reparation is due the person who has been required to pay an unlawful charge. A shipper who has paid such a charge and is the owner of the goods transported is entitled to repayment, without the imposition of the impossible task upon the Commission of ascertaining the ultimate profits which accrued from his business. He is entitled to reparation irrespective of his profits. ${ }^{22}$

${ }^{22}$ Kindelon v. S. P. Co., 17 I. C. C. $251,255$. 
Statute of Limitations.-The period of two years prescribed by the statute within which the Commission is allowed to award damages for acts arising under violations of the provisions of the Act, begins to run at the time when the shipment is delivered and when it becomes the legal duty of the carrier to collect its lawful chargenot at the time of the payment of the freight by the shipper.

In a typical case, shipments moved in October and November, 1906, but on account of a controversy as to the rates lawfully applicable, the payment of charges was delayed until June 3, 1909. Complaint was not filed until August 17, 1909. It was held that, ${ }^{23}$ more than two years having elapsed between the delivery of the shipments and the institution of proceedings, the claims were barred. ${ }^{24}$

Method of obtaining reparation.-There are two courses of procedure for the obtaining of reparation. One is the filing of what is called a formal complaint, and the other, an informal complaint. An informal complaint is filed in a case where the carrier admits that it has violated the Act and is willing to make reparation to the injured party. In such cases it signs with the complainant the petition presented to the Commission, and asks permission from the Commission to make reparation. The other case, that of a formal complaint, arises in contested cases, where the carrier will not admit that it is at fault. An important thing to remember is that in the complaint alleging discrimination, the exaction of an unreasonable rate, or the like, the complainant must demand reparation. Otherwise, damages cannot afterwards be obtained, even if the rate or practice is adjudged to be in violation of the Act.

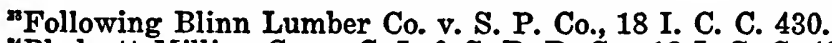

"Blodgett Milling Co. v. C. I. \& S. R. R. Co., 18 I. C. C. 439. 
No reparation will be awarded on informal proceedings which would not be awarded under the same set of facts in a contested case. The Commission cannot accept as conclusive any stipulation of parties as to the reasonableness of a rate or a transportation regulation. The Commission's conclusions on such matters must be reached with due consideration for the conclusions which it has already announced on the same subject, and for the knowledge which it has already gathered or announced on the same subject. The willingness of a shipper to receive and of a carrier to pay reparation upon certain traffic, or under certain rates, can be approved by the Commission only under a clear and decisive showing of facts that would lead the Commission to award that reparation in opposition to the carrier's wishes. It must be prepared to award reparation to all others who might have shipped during the same period under the same rate and under substantially similar circumstances and conditions. ${ }^{25}$

Court pleadings.-Often the Commission awards reparation but the railroads refuse to obey the order of the Commission. It is then necessary to bring an action in the courts, based on the award of the Commission. In such cases, Section 16 makes the findings of the Commission prima facie evidence of the fact therein stated.

In a suit in a state court to recover reparation for unjust discrimination, the court is not required by Section 14 of the Act to take judicial notice of the decisions of the Commission where they are not mentioned in the pleadings or in the agreed statement of facts. This provision makes the decisions of the Commission as published admissible in evidence without other proof of their

${ }^{25}$ Swift \& Co. v. C. \& A. R. R. Co., 16 I. C. C. $426,428$. 
genuineness, but does not relieve litigants from the necessity of offering them in evidence. ${ }^{26}$

In a suit in a United States circuit court to recover the excess of freight charges exacted above the published rate, the declaration failed in terms to state the particular rates that had been passed upon by the Interstate Commerce Commission, but indicated that it was the purpose of plaintiff to incorporate by reference the pertinent facts of the decisions into the declaration. It was held that in determining the sufficiency of the declaration upon demurrer, the court might examine the facts set out in the decisions referred to. ${ }^{27}$ Any order of award, conclusion, opinion, or argument of the Commission must be eliminated in determining the sufficiency of a declaration which includes said report, since only facts found by the Commission and alleged in the declaration can be considered in deciding whether or not a cause of action is stated. This ruling is based on Section 14 of the Act, requiring the Commission, in case damages are awarded, to include in its report the finding of fact on which the award is made, and on Section 16 of the Act, providing that, in a suit to recover in a United States circuit court the excess charge, the suit shall proceed in all respects like all civil suits for damages except that the finding and order of the Commission shall be prima facie evidence of the facts therein stated. ${ }^{28}$

In all cases where a suit in a court is brought to enforce an order of the Commission, the complainant can recover attorney's fees.

${ }^{2}$ Robinson v. B. \& O. R. R. Co., 222 U. S. 506, 512.

${ }^{2}$ Phillips Co. v. G. T. W. Ry. Co., 195 Fed. 12, 16.

${ }^{28}$ Darnell-Taenzer Lumber Co. v. S. P. Co., 190 Fed. 659, 663. 


\section{SECTION 16a}

Rehearings.-This section provides that after a decision, order, or requirement has been handed down by the Commission in any proceeding, any party thereto may at any time make application for rehearing of the same, or any matter determined therein. It shall be lawful for the Commission in its discretion to grant such a rehearing if sufficient reason therefor be made to appear. Applications for rehearing shall be governed by such general rules as the Commission may establish. No such application shall excuse any carrier from complying with or obeying any decision, order, or requirement of the Commission, or operate in any manner to stay or postpone the enforcement thereof, without the special order of the Commission. In case a rehearing is granted, the proceedings thereupon shall conform as much as possible to the proceedings in an original hearing, except as the Commission may otherwise direct.

If, in its judgment, after the consideration of all facts, including those arising since the former hearing, it shall appear that the original decision, order, or requirement is in any respect unjust or unwarranted, the Commission may change the same. Any decision, order, or requirement made after such rehearing or changing of the original determination, shall be subject to the same provisions as an original order. In conjunction with this, read Section 16a, Rehearing. 


\section{SECTION 17}

\section{Procedure}

In general.-Section 17 provides that the Commission may conduct its proceedings in such manner as will best conduce to the proper dispatch of business and to the ends of justice. It may from time to time make or amend such general rules or orders as may be requisite for the order and regulation of proceedings before it. Any party may appear before it and be heard in person or by attorney.

The Commission has absolute power over its procedure. This section, however, should be read in connection with Sections 16 and 16a, which to some extent, as has been noted, more clearly define the Commission's authority in this respect. Section 16 gives the Commission authority to modify its orders, and Section 16a grants more specific authority concerning rehearings. The Commission has endeavored to simplify its practice and procedure, not permitting technical matters to interfere with substantial results. In order that shippers unskilled in such matters might bring their troubles to the Commission in their own proper persons, the practice rules of the Commission, while not overlooking the definite requirements of the law in respect to filing complaints, are intended to relieve complainants, as far as possible, from observance of the more technical rules of pleading.

The Commission has published rules of procedure. ${ }^{1}$ It is necessary for this body to have some kind of system

\footnotetext{
'These rules will be found in "Procedure Before the Interstate Commerce Commission."
} 
in the practice and trial of thousands of cases pending before it. Naturally, some questions have arisen. We will consider briefly the more important ones.

Complaint.-It is due both to the Commission and to the defendant carrier that a complainant should state seasonably whether he will claim reparation, and that both the Commission and the carrier may be advised of the nature of his claim. Every rule of convenience and of justice requires that where a large number of existing rates are attacked, a statement should be made in general terms that reparation will be claimed when a decision finally reducing the rates is made. The matter may thus be held in abeyance until the main question has been decided and the parties know whether any reparation will be awarded.

Upon a complaint alleging undue preference, it was held that the question of the reasonableness per se of rates is automatically imported into a case through the suspension of the tariffs. However, a complaint does not raise the issue that rates are discriminatory when it simply contains a general allegation that the rates of the defendant violate Sections 1, 2, and 3 of the Act, and there is no attempt to point out in any particular the character of the discrimination, the locality involved, or any prayer for its correction. If a question of discrimination in rates is not specifically alleged in the complaint, but is actually tried upon the hearing, the Commission may allow an amendment upon such terms as would properly protect the defendants. It cannot, however, decide that question when raised for the first time in the briefs. The remedy of complainants is to file a separate complaint to that specific end.

While the Commission is extremely liberal in construing the pleadings before it, the statute requires that carriers shall be notified of the complaint which they are re- 
quired to answer. Though no particular form is insisted upon, there must be a statement of the thing which is claimed to be wrong, sufficiently plain to put the carrier upon its defense. ${ }^{2}$

Therefore, the Commission, fully weighing all of the pertinent facts and testimony adduced, can take judicial cognizance of and make findings upon only such issues as are clearly raised by the complaint. An examination into the specific provisions of the Act, especially into those of Section 13, will make clear to the candid mind that a complaint before the Commission was not intended to be regarded in the same strict and hard light as a complaint in an action at law, but was to be regarded as an appeal to the Government against oppressive, unjust, and illegal action. A shipper may not dismiss his complaint without consent. The fact that he has no interest in the traffic concerned in his complaint does not put him out of court. These and similar provisions indicate that the purpose of Congress in enacting the Act was to establish a body whose function should be to protect the public interest, and not merely regard the technical rights of an individual shipper. In this view of the law the Act has been administered by the Commission. ${ }^{3}$

But the Commission is not disposed to try complaints piecemeal. If a complainant desires to secure reparation upon traffic, in respect of which he also seeks reduction of the rate for the future, he may reasonably be required to present his whole case at once. The Commission enforces in its investigation only the most elementary rules of procedure, requiring merely that the complainant shall set forth concisely an alleged violation of the Act. It is aimed to avoid technical rules that might impede the way to substantial justice, and to determine each case upon

${ }^{2}$ U. S. Leather Co. v. S. Ry. Co., 21 I. C. C. 323, 324.

${ }^{3}$ Advances in Rates-Western Case, 20 I. C. C. $307,315$. 
the merits alone. Obviously, however, it is in the interest of good administration that an entire case should be presented to the Commission and to the defendants.

Cases are ordinarily assigned for hearing at some point convenient to the complainant; but each hearing involves attendance by a member of the Commission or an examiner, and of the defendant's counsel and witness at the place assigned. If, after an order for the future is secured, the complainant may institute another proceeding for reparation on past shipments, a second hearing becomes necessary, which may involve an expenditure of public funds and a hardship upon the defendants quite out of proportion to the amount sought to be recovered. Moreover, it does not follow that because the Commission has found a rate unreasonable and established a lower rate for the future, the former rate was unreasonable at all times in the past. In such a proceeding as this, therefore, a second and independent investigation would be unavoidable.

Notice of complaint.-Section 13 of the Act requires the Commission, when a complaint stating the facts is filed, to forward the same "to such common carrier, who shall be called upon to satisfy the complaint or to answer the same in writing within a reasonable time to be specified by the Commission." Notice should be given only to the party immediately interested and not to those remotely concerned. Since full publicity, however, attends every step of all proceedings before the Commission, it must be assumed that parties interested will take notice of what is going on.

Amending complaint.-Where a complaint seeking reparation for certain claims is filed before the expiration of the limitation period applicable to such claims, and, upon motion of complainant, is dismissed without prejudice, the Commission may in its discretion reinstate 
said original petition by a nunc pro tunc order as of date of the filing of the complaint in the first place. It cannot, however, reinstate such a complaint when the same has been amended to include claims not embraced in the original complaint, which are at the time of the motion for reinstatement barred by the Statute of Limitations. The Commission cannot sanction a practice permitting the revival of claims barred by the statute by subsequently attaching them to other claims, presented within the prescribed period. This is true despite any promises on the part of the defendant carriers that they will not take advantage of the Statute of Limitations. The Commission has no jurisdiction to deal with complaints for reparation in any way, unless they are filed with or presented to it within the time provided by law, and do not have the powers of a court of equity to relieve from hardships resulting from improvident arrangements or agreements between the parties.

Hearing.-While the Act does not presume to cast the burden of proof entirely upon the complainant to establish the unreasonableness of a rate complained of, as would be the case in a court of law, nevertheless a complainant is not relieved of all responsibility as to his case upon the mere filing of a complaint. Where, after due notification, he appears neither in person nor by counsel at the hearing; and his application is primarily one for reparation, his complaint must be dismissed.

Rehearing.-When full opportunity for hearing has been accorded, parties must show as ground for a rehearing that the evidence which they now offer either could not or ought not to have been previously introduced; also that this evidence, if admitted, will probably lead to a reversal. It is no hardship to require carriers, in the trial of their cases before the Commission, to observe to a very moderate degree the same rules that 
would obtain in a trial at law. Whenever the Commission is convineed that its order works substantial injustice, it will unhesitatingly set aside that order. It cannot, however, continually retry cases upon the mere statement of the carrier that it desires to introduce some further testimony, or that it believes that the decision of the Commission is wrong.

The rules regarding rehearing shonld be considered in connection with Section 16a, already referred to.

Orders of the Commission.-The Commission is an administrative body. The rates, regulations, and practices that it establishes within its jurisdiction become fixed rules of action. From time to time it may be necessary to change these rulings as varying conditions require, but this should never be done except upon due notice to the public, which is affected by them. It would, of course, be altogether intolerable if the change could be made retroactive. ${ }^{4}$

But an order of the Commission for the payment of money does not have the effect of an order, decree, or judgment of a court; it is not enforceable by process, nor does it become a lien upon the property of the defendant.

The Commission may likewise modify its orders as it sees fit.

'Nebr.-Iowa Grain Co. v. U. P. R. R. Co., 15 I. C. C. 90, 93. 


\section{SECTION 18}

Salaries of Commission.-Section 18 provides that the Commission shall appoint a secretary, who shall receive an annual salary of $\$ 5,000$. The Commission also has authority to employ and fix the compensation of such other employes as it may find necessary for the proper performance of its duties. Until otherwise provided by law, the Commission may hire suitable offices for its use, and shall have authority to procure all necessary office supplies. Witnesses summoned before the Commission shall be paid the same fees and mileage that are paid to witnesses in the courts of the United States.

All of the expenses of the Commission, including all necessary expenses for transportation incurred by the Commissioners, or by their employes under their orders in making any investigation, or upon official business in any place other than in the city of Washington, shall be allowed and paid on the presentation of itemized vouchers approved by the Chairman of the Commission. While Section 18 also fixes the salaries of the Commissioners, it has been superseded in this respect by Section 24, to which the reader should refer. 


\section{SECTION 19}

Office of the Commission.-Section 19 provides that the principal office of the Commission shall be in the city of Washington, where its general sessions shall be held; but whenever the convenience of the public or the parties may be promoted, or delay or expense prevented thereby, the Commission may hold special sessions in any part of the United States. ${ }^{1}$ It may, by one or more of the Commissioners, prosecute any inquiry necessary to its duties, in any part of the United States, into any matter or question of fact pertaining to the business of any common carrier subject to the provision of this Act.

Owing to the enormous amount of work now imposed upon the Commission, hearings, particularly away from the city of Washington, are conducted by examiners, who are especially appointed to make investigations and to hear testimony.

${ }^{1}$ As a matter of fact, hearings are constantly being held in all parts of the country. 


\section{SECTION 20}

\section{Reports}

Section 20 provides that the Commission is authorized to require annual reports from all common carriers subject to the Act, and from the owners of all railroads engaged in interstate commerce as defined in the Act. It has power, also, to prescribe the manner in which such reports shall be made, and to require from such carriers specific answers to all questions upon which the Commission may need information. Such annual reports must show in detail the amount of capital stock issued, the amounts paid therefor, and the mamner of payment for the same; the dividends paid, the surplus fund, if any, and the number of stockholders; the funded and floating debts, and the interest paid thereon; the cost and value of the carrier's property, franchises, and equipments; the number of employes and the salaries paid each cliss; the accidents to passengers, employes, and other persons, and causes thereof; the amounts expended for improvements each year, how expended, and the character of such improvements; the earnings and receipts from each branch of business and from all sources; the operating and other expenses; the balances of profit and loss; and a complete exhibit of the financial operations of the carrier each year, including an annual balance sheet.

Such reports shall also contain such information in relation to rates or regulations concerning fares or freights, agreements, arrangements, or contracts affecting the same as the Commission may require; and the Commission may, in its discretion, for the purpose of en- 
abling it the better to carry out the purposes of the Act, prescribe a period of time within which all common carriers subject to the provisions of this Act shall have, as near as may be, a uniform system of accounts, and the manner in which such accounts shall be kept. The Commission has done this and all carriers now operate under uniform accounting regulations.

Said detailed reports must contain all the required statistics for the period of the preceding twelve months, and must be made out under oath and filed with the Commission at its office in Washington within three months after the close of the year for which the report is made, unless additional time be granted in any case by the Commission. The Commission is also given authority to require carriers to file monthly reports of earnings and expenses, and to file periodical or special, or both periodical and special, reports concerning any matters about which the Commission is anthorized or required by this or any other law to inquire or to keep itself informed, or which it is required to enforce; and, whenever the Commission so requires, such periodical or special reports shall be under oath. A penalty of $\$ 100$ a day accrues for failure to file these reports.

The Commission is also given power to prescribe the forms of any and all accounts, records, and memoranda to be kept by carriers subject to the Act, including the accounts, records, and memoranda of the movement of traffic, as well as the receipts and expenditures of moneys. The Commission has at all times access to all accounts, records, and memoranda kept by carriers. It is unlawful for such carriers to keep any other accounts, records, or memoranda than those prescribed or approved by the Commission. The latter may employ special agents or examiners, who have authority under the order of the Commission to inspect and examine any and 
all accounts, records, and memoranda kept by such carriers. The penalty is $\$ 500$ a day for refusal to permit the Commission to inspect the records.

Any person who willfully makes any false entry in the accounts of any book of accounts or in any record or memoranda kept by a carrier, or who willfully destroys, mutilates, alters, or by any other means or device falsifies the record of any such account, record, or memoranda, or who willfully neglects or fails to make full, true, and correct entries, in such accounts, records, or memoranda, of all facts and transactions appertaining to the carrier's business, or who keeps any other accounts, records, or memoranda than those prescribed or approved by the Commission, is guilty of a misdemeanor. The offender is subject, upon conviction in any court of the United States of competent jurisdiction, to a fine of not less than $\$ 1,000$ and not more than $\$ 5,000$, or to imprisonment for a term not less than one year and not more than three years, or to both such fine and imprisonment.

Section 20 further provides that any examiner who divulges any fact or information which may come to his knowledge during the course of such examination, except in so far as he may be directed by the Commission or by a court or judge thereof, shall be subject, upon conviction in any court of the United States of competent jurisdiction, to a fine of not more than $\$ 5,000$, or imprisonment for a term not exceeding two years, or both.

In passing Section 20 of the Act, giving the Commission authority to prescribe an accounting system and to require reports of carriers covering both interstate and intrastate business, Congress did not exceed its power under the commerce clause of the Constitution. ${ }^{1}$ Ed. 729

${ }^{1}$ I. C. C. v. Goodrich Co., 224 U. S. 194, 214; 32 Sup. Ct. 436 ; 56 L. 
Under Section 20 the Commission has power to require the carrier's engaged in interstate commerce to make monthly reports of instances of service in excess of the time allowed, provided a separate form of oath is accepted in lieu of such reports in cases where no employe has been employed in excess of the time named in the Act. An order of the Commission, under the Act as amended, requiring the secretary or similar officer of carriers engaged in interstate commerce to make monthly reports of violations of the restrictions as to hours of service of employes, is not in violation of the fourth and fifth amendments of the Constitution relating to unreasonable search and seizure and self-crimination. It merely authorizes the Commission to require reports from common carriers and owners engaged in interstate commerce. In the absence of such an order by the Commission, mandamus will not lie to compel carriers to make such reports.

Under Section 20 the Commission is also authorized to require reports from and to prescribe systems of bookkeeping and accounting for steamship companies operating on the Great Lakes. It has authority, however, only with respect to interstate business carried on under a common arrangement with rail carriers, and not with respect to port-to-port interstate or port-to-port intrastate business of such carriers. ${ }^{2}$

Neither does the clause in Section 20 declaring it unlawful for carriers engaged in interstate commerce to keep any accounts, records, or memoranda other than those prescribed by the Interstate Commerce Commission, prevent the states from prescribing additions to the system of bookleeping fixed by the Interstate Commerce Commission so as to complete the information necessary

${ }^{2}$ Goodrich Transit Co. v. I. C. C., 190 Fed. 943, 958, 966. 
for the regulating of intrastate rates, for the clause refers only to interstate commerce. ${ }^{3}$

Very often the accounting officers do not follow the strict rules of the Commission. It is important that this be done in order that uniform accounts be had.

Accounting officers understand the true functions of accounts and realize their importance in determining the correct cconomic condition of the transportation properties with which they are affiliated. Their instincts and training are such as naturally to lead them to keep their accounts as they should be kept. They would not have the eonfidence of their superior officers if this were not the case. But in many instanees the aecounting officers of carriers have not been left free to follow their natural inelinations in this regard. Irrespective, however, of the influences brought to bear upon an accounting officer to turn him from his true course as an accountant and from his duty, under the law, of keeping the accounts in accordance with the system prescribed by the Commission, it is nevertheless his hand, or the hand of someone immediately under his authority, that makes the wrongful record and it is the accountant, therefore, to whom the Commission must look in the first instance for the proper carrying out of its rules and regulations. Under our regulations and prescribed form, the oath of the accounting officer must be attached to the annual report of the carrier to the Commission, together with that of the executive; and, from the necessities of the case, it is the accounting officer who is immediately responsible and whom the Commission will first hold responsible when it becomes necessary to invoke the penalties of law; but we shall not hesitate to call to account with even greater severity anyone above the accounting officer in authority who may share in the responsibility for any violations of the accounting rules and regulations which have been prescribed for the use of the earriers that are subject to the Act. ${ }^{4}$

It is unnecessary to emphasize the necessity and importance of carriers' statistical reports that will be uniform and truly reflect their condition. Recent years have witnessed the exposure of glaring instances of the financial wrecking of transportation agencies by those in posi-

${ }^{8}$ R. R. Com. of Tex. v. P. T. \& P. Ry. Co. (Tex., 1911), 140 S. W. 829,835 .

'St. Paul \& Puget Sound Accounts, 29 I. C. C. 508,518, 
tions of authority. In many instances the application of correct accounting rules and principles, with proper knowledge on the part of stockholder's and the public of the conditions thus reflected, would have gone far to avoid such consequences. ${ }^{5}$

In a typical case, defendant contended that Section 20 of the Interstate Commerce Act, in conferring on the Commission power to prescribe the form of accounts, records, and memoranda to be kept by carriers, recognizes a distinction between the form and the substance; and that, while the Commission, to obtain full and accurate information concerning the affairs of each corporation, must have power to require reports, schedules, and accounts necessary to show its true financial condition, yet the grant must, by fair interpretation and in order not to amount to an unconstitutional delegation of legislative power, stop short of the point where the regulation in its essence goes not to the form but to the substance and involves interference with the internal affairs of the corporation. It was held that no such distinction between form and substance is admissible with respect to the declared object of standardizing railroad accounts and obtaining therefrom full and accurate information concerning the affairs of the respective corporations. In order that accounts may be standardized there must be uniformity. So far as regulations for uniformity control or tend to control the conduct of the carrier in its capacity as a public servant engaged in interstate commerce, they are within the authority constitutionally conferred by Congress upon the Commission. There is no direct interference with the internal affairs of the corporation; and if any such interference indirectly results, it is only

${ }^{5}$ St. Paul \& Puget Sound Accounts, 29 I. C. C. 508, 517. 
such as is incidental to the lawful control of the carrier by the Federal Government. ${ }^{6}$

\section{The Carmack Amendient}

In general.-Section 20 also contains what is known as the Carmack Amendment, which makes the initial carrier liable for loss or damage occurring to a shipment while off its rails in the possession of a connecting carrier. This provision of the Act is so important that we shall quote it verbatim.

Any common carrier, railroad, or transportation company receiving property for transportation from a point in one State to a point in another State shall issue a receipt or bill of lading therefor and shall be liable to the lawful holder thereof for any loss, damage, or injury to such property caused by it or by any common carrier, railroad, or transportation company to which such property may be delivered or over whose line or lines such property may pass, and no contract, receipt, rule, or regulation shall exempt such common carrier, railroad, or transportation company from the liability hereby imposed; provided, That nothing in this section shall deprive any holder of such receipt or bill of lading of any remedy or right of action which he has tinder existing law.

That the common carrier, railroad, or transportation company issuing such receipt or bill of lading shall be entitled to recover from the common carrier, railroad, or transportation company on whose line the loss, damage, or injury shall have been sustained the amount of such loss, damage, or injury as it may be required to pay to the owners of such property, as may be evidenced by any receipt, judgment, or transcript thercof.

This provision has completely changed the method of proving claims against carriers, which had existed before its passage. Formerly, if a shipper presented a claim against a railroad, in many of the states he had to prove on which connecting line the loss or damage occurred.

${ }^{\circ}$ K. C. S. Ry. Co. v. U. S., 34 Sup. Ct. 125,$130 ; 231$ U. S. $423 ; 58$ L. Ed. 
In many instances this was impracticable, and resulted in considerable hardship. In 1906, therefore, Congress passed this section, known as the Carmack Amendment. This makes the initial carrier liable for the loss, no matter where it occurs.

The Carmack Amendment, requiring carriers in interstate commerce, as a condition of continuing in that traffic, to obligate themselves to carry freight to the point of destination, using the lines of the comnecting carriers as their own agencies, is not beyond the scope of the power of regulation. It is, therefore, not unconstitutional as denying the right of contract, since the right to freedom of contract is not unlimited, and the regulation imposed is not mmwarranted abridgment thereof. It is merely a denial of such right to the extent of forbidding or regulating every contract which is reasonably calculated to affect injuriously the public interest. ${ }^{7}$

The Carmack Amendment is not in violation of the third amendment of the Constitution in taking the property of the initial carrier to pay the debt of an independent connecting carrier whose negligence may have been the sole cause of the loss, since the resulting liability of the initial carrier is that of a primcipal for the negligence of its own agent. ${ }^{\mathrm{s}}$

Considerable doubt was expressed as to the constitutionality of that part which provides for contribution from connecting carriers. It is now well settled, however, that the portion of the Carmack Amendment providing that the carriers issuing the receipt or bill of lading shall be entitled to recover from the carrier on whose line the loss or damage occurs, "the amount of such loss, damage, or injury as it may be required to pay to the owners of such property, as may be evidenced by any

'A. C. L. R. R. Co. v. Riverside Mills, 219 U. S. 186.

A. C. L. R. R. Co. v. Riverside Mills, 219 U. S, 186, 
receipt, judgment or transcript thereof,' is not unconstitutional; for it makes the receipt, judgment, or transcript only prima facie or presumptive, and not conclusive, evidence. ${ }^{9}$

Jurisdiction of Commission.-Claims for loss and damage under the Carmack Amendment are not within the juriscliction of the Interstate Commerce Commission; such suits can be prosecuted only in a court.

Jurisdiction of state courts.-In a suit against an initial carrier under the Carmack Amendment for a failure to deliver goods at destination, a state court has jurisdiction, since the act complained of is not a violation of the original Act of 1887, and the Interstate Commerce Commission does not, therefore, have exclusive jurisdiction under Section 9 of the present Act. ${ }^{10}$ The Carmack Amendment, making the initial carrier liable for loss or damage occurring on its ows line or on that of a connecting carrier, will be recognized and enforced by the state courts. ${ }^{11}$ So a state court has jurisdiction under the Carmack Amendment to entertain an action against an initial carrier for damages caused by a comnecting carrier in failing to carry an interstate shipment of peaches with reasonable despatch, and to keep the same properly iced. ${ }^{12}$

Sections 8 and 9 of the Interstate Commerce Act declare a liability for clamages which result where the common carrier "shall do, cause to be done, or permit to be done, any act, matter, or thing in this Act prohibited or declared to be unlawful or shall omit to do any act, matter, or thing in this Act required." It was held that the liability created by the Carmack Amendment to the Hep-

${ }^{9} \mathrm{C}$. of Ga. Ry. Co. v. Sims, 169 Ala. 295, 301; 53 So. 826.

${ }^{10}$ G. H. \& S. A. Ry. Co. v. Wallace, 223 U. S. 481.

${ }^{11}$ C. of Ga. Ry. v. Sims, 169 Ala. 295,$300 ; 53$ So. 826.

${ }^{12}$ S.t. L. \& S. F. R. R. Co. v. Heyser (Ark., 1910), 130 S. W. 562, 564. 
burn law, making the initial carrier of an interstate shipment responsible for loss or damage occurring on the line of a connecting carrier, is not governed by said Sections 8 and 9 , so as to give the Interstate Commerce Commission and the federal courts exclusive jurisdiction, but since the liability under the Carmack Amendment was not created by the Interstate Commerce Act, state courts have at least concurrent jurisdiction with the Commission and the federal courts. ${ }^{13}$

Liability of initial carrier.-Under the Carmack Amendment the initial carrier is responsible for any loss or damage which occurs on a line of any other carrier. No carrier can limit its liability so as to avoid this obligation. However, inasmuch as the Carmack Amendment only applies to transportation from one state to another, the initial carrier in the United States is not liable for a loss which occurs on the ocean, on a shipment destined to a foreign country. Thus, suppose a shipper in San Francisco was to ship goods to Cuba via New York. The originating carrier would be liable for any loss which occurred to the shipment to the port of New York; but after it was transshipped there and put on the steamer it would not be responsible for any loss or damage that occurred while in the possession of that carrier, because the shipment would then be destined to a point not in the United States. On a shipment from Pittsburgh to San Francisco by way of New York, even if the shipment was transshipped at New York, and damaged while in the possession of the water carrier, the originating carrier would still be liable, because the shipment would be destined to a point in the United States.

Limitation of liability.-It is important to note that under the Carmack Amendment the carrier has the right, however, to restrict its liability when such restriction of

${ }^{2}$ St. L. \& S. F. R. R. Co. v. Heyser (Ark., 1910), 130 S. W. 562, 565. 
liability is a rate based on value. So, the valuations declared or agreed upon, as evidenced by the contract of shipment upon which the published rate is applied, must be conclusive in an action to recover a greater sum for loss or damage. ${ }^{\mathbf{1 4}}$

When a shipper delivers a package for shipment and declares a value, either upon request or voluntarily, and the carrier makes a rate accordingly, the shipper, in case of loss or damage, is estopped from recovering any greater amount. ${ }^{15}$

The Carmack Amendment does not forbid a limitation of liability in case of loss or damage to a valuation agreed upon for the purpose of determining which of two alternative lawiful rates shall apply to a particular shipment.

In an interstate shipment of bulls and cows, the shipping receipt stated that the carrier did not haul these animals for the lower rate specified as applying, except upon valuation of $\$ 30$ and $\$ 20$ per head for the bulls and cows, respectively, and thereafter recited that the shipper represented the value as not exceeding these sums. In the tariffs, a higher rate was specified, where the liability was unlimited. It was held that the shipper, having accepted this receipt, could not recover in excess of the sums limited for loss of the stock, notwithstanding the provision of the Carmack Amendment relating to exemption of liability. ${ }^{16}$

Under the law it is a duty of shipper's of property of more than ordinary value to bill the same at its true value, in order that the legal rate may be applied. In the case of the shipper's declaring a false value to secure a reduced rate, one of the penalties under a form of receipt basing the rate on valuation is an estoppel. By this he

${ }^{14}$ K. C. S. R. R. Co. v. Carl, 33 Sup. Ct. 391, 395; 227 U. S. 639.

${ }^{15}$ K. C. S. R. R. Co. v. Carl, 33 Sup. Ct. 391.

${ }^{16}$ M. K. \& T. R. R. Co. v. Harriman Bros., 227 U. S. 657. 
is precluded, in case of loss or damage, from denying the correctness of a value so given. ${ }^{17}$

Plaintiff shipped a carload of pig tin, consisting of 320 pigs of substantially the same size. Under the published interstate rates, 23 cents per 100 pounds was fixed for carload lots only, "released to valuation of $\$ 100$ per ton of 2,000 pounds, to be shown on bills of lading and shipper's invoice,' and 30 cents per 100 pounds without any limitation of liability. Plaintiff signed a bill of lading upon which was stamped the statement that in case of loss or damage to the property therein described he would not assert claim against the carrier on a higher basis of value than $\$ 100$ per ton. Forty of the pigs were lost in transit. It was held that the limited liability applied to each part of the cargo, and plaintiff was therefore not entitled to recover the full value of the tin lost so long as it did not exceed the value of the entire load, but was only entitled to recover at the rate of $\$ 100$ per ton on the actual weight lost. ${ }^{18}$

The valuation declared or agreed upon, as evidenced by the contract of shipment upon which the published tariff rate is applied, is conclusive between parties. ${ }^{19}$ But where a carrier's agent is not authorized to accept shipments under the common-law liability and is authorized to accept them only for a limited liability under a higher rate, the contract limiting liability is invalid even though the shipper makes no demand to ship under the common-law liability. ${ }^{20}$

A bill of lading of an interstate shipment contained the condition that the amount of the loss or damage for 138.

${ }^{17}$ Express Rates, Practices, Accounts, and Revenues, 28 I. C. C. 131, ${ }^{138}$ United Lead Co. v. L. V. R. R. Co. (N. Y., 1913), 141 N. Y. S. 310. 310.

${ }^{19}$ United Lead Co. v. L. V. R. R. Co. (N. Y., 1913), 141 N. Y. S.

${ }^{20}$ C. C. C. \& St. L. Ry. Co. v. Hayes (Ind., 1913), 102 N. E. $34,41$. 
which any carrier was liable should be computed on the basis of the value of the property (being the bona fide price, if any, to the consignee). It was held that the provision was not invalid, under the Carmack Amendment to the Interstate Commerce Act. ${ }^{21}$

Liability for negligence.-However, while the carrier has the right to publish rates based on value and restrict its liability to the valuation so imposed, it cannot release its liability for a loss caused through its own negligence, because such provisions are void under the Carmack Amendment. So provisions forbidding exemption of liability are a statutory declaration that a contract of exemption from liability for negligence is against public policy and void. ${ }^{22}$

An agreement to release a carrier for part of a loss due to negligence is no more valid, under the Carmack Amendment, than one whereby there is complete exemption. Neither is such a contract any more valid because it rests upon a consideration than if it were without consideration. ${ }^{23}$

But by the provision of the Carmack Amendment the liability imposed on the carrier for loss or damage in interstate shipments is the liability imposed by the common law upon the common carrier, and may be limited or qualified by special contract with the shipper, provided the limitation or qualification be just and reasonable, and does not exempt from loss or responsibility due to negligence. $^{24}$

So in consideration of a lower rate the shipper may agree that the carrier's liability shall be limited to a certain amount in case of loss or damage to the shipment.

${ }^{21}$ Coleman v. N. Y. N. H. \& H. R. R. Co. (Mass., 1913), 102 N. E. 92,94 .

${ }^{22}$ K. C. S. R. R. Co. v. Carl, 227 U. S. 639.

${ }^{23}$ K. C. S. R. R. Co. v. Carl, 33 Sup. Ct. 391 , $394 ; 227$ U. S. 639.

${ }^{21}$ M. K. \& T. R. R. Co. v. Harriman Bros., 33 Sup. Ct. 397,$401 ; 227$ U. S. 657 . 
The provisions of the Interstate Commerce Act do not preclude the shipper, after paying the legal rates, from receiving or recovering for injuries to the property transported caused by the carrier's negligence. ${ }^{25}$

Notice of loss.-Very often bills of lading contain provisions that notice of loss or damage to a shipment must be presented to the carrier within a specified time. Under the Carmack Amendment, making the initial carrier of an interstate shipment liable for loss or damage caused by itself or connecting carriers, a provision in the shipping contract requiring the shipper to present a claim in writing for loss or damage to the carrier, at the point of shipment or delivery, within four months after delivery, is not invalid. ${ }^{26}$

Under the Interstate Commerce Act, which is controlling upon a state court in determining questions of liability properly arising ont of interstate shipments, the courts will uploold the validity of a provision in a livestock contract or bill of lading to the effect that, as a condition precedent to a recovery for any damages for delay, loss, or injury to live stock covered by the contract, the shipper will give notice in writing of the claim, before said stock is removed from the point of shipment or the place of destination, and before such stock mingles with other stock. Such notice is to be given to some general officer, to the nearest station agent, to the agent at destination, or to some general officer of the delivering line, and is to be served vithin one day after delivery of such stock at destination. ${ }^{27}$

The Carmack Amendment does not prohibit an agreement providing a reasonable time within which the shipper must present his claim or give notice of claim for

${ }^{25}$ Ore. R. \& N. Co. v. Thisler (Kans., 1913), 133 P. 539, 539.

${ }^{26}$ A. C. L. R. R. Co. v. Ward (Ala., 1912), 58 So. $677,678$.

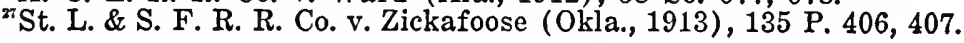


loss or damage, or the carrier shall not be liable. Likewise, nothing in the Carmack Amendment invalidates a provision in a bill of lading of an interstate shipment requiring claims for loss or damage to be made in writing to the carrier at the point of delivery or at the point of origin within four months after delivery of the property, or in case of failure to make delivery within four months after a reasonable time for delivery has elapsed. ${ }^{28}$ This is included in the third section of the Uniform Bill of Lading. However, since the Carmack Amendment abolishes the stipulation for separate liability of comnecting carriers of interstate freight, notice to a connecting carrier of loss or damage to live stock is notice to the initial carrier. $^{29}$

${ }^{28} \mathrm{~J} o s e p h$ v. C. B. \& Q. R. R. Co. (Mo., 1913), 157 S. W. $837,838$.

${ }^{20}$ C. R. I. \& G. Ry. Co. v. Linger (Tex., 1913), 156 S. W. 298, 299. 


\section{SECTION 21}

Report by Commission.- Section 21 provides that the Commission shall, on or before the first day of December in each year, make a report, which shall be transmitted to Congress, and copies of which shall be distributed, as are the other reports, to Congress. This report should contain such information and data collected by the Commission as may be considered of value in the determination of questions comnected with the regulation of commerce, such recommendations regarding additional legislation relating thereto as the Commission may deem necessary, and the names and compensation of the persons employed by said Commission. The annual report of the Commission is a very instructive publication, which can be secured from the Superintendent of Documents a reasonable time after it is transmitted to Congress.

The annual report of the Commission shows more than any other source of information the wide scope of the Commission's authority as now constituted. 


\section{SECTION 22}

\section{Reduced Rates}

Section 22 provides that no provision of the Act shall prevent the carriage, storage, or handling of property free or at reduced rates for the United States, state, or municipal governments, or for charitable purposes, or to or from fairs and expositions for exhibition thereat, or the free carriage of destitute and lomeless persons transported by charitable societies, and the necessary agents employed in such transportation, or the issuance of mileage, excursion, or commutation passenger tickets. The railroad is also authorized to give reduced rates to ministers of religion, or to municipal governments for the transportation of indigent persons, inmates of national homes or state homes for disabled volunteer soldiers and inmates of soldiers' and sailors' orphan homes, including those returning home after discharge, under arrangements with the boards of managers of such homes.

The railroad is likewise authorized to give free carriage to its own officers and employes, or the officers of any railroad company with which it exchanges passes or tickets. It also permits the issuance of joint interchangeable 5,000-mile tickets, with special privileges as to the amount of free baggage that may be carried under mileage tickets of 1,000 miles or more. But before any carrier may issue any such joint interchangeable mileage tickets with special privileges, it must file with the Interstate Commerce Commission copies of the joint tariffs of rates, fares, or charges on which such joint interchangeable mileage tickets are to be based, together with 
specifications of the amount of free baggage permitted to be carried under such tickets, in the same manner as common carriers are required to do with regard to other joint rates by Section 6 of the Act; and all the provisions of Section 6 relating to joint rates, fares, and charges must be observed by such carriers and enforced by the Interstate Commerce Commission as fully with regard to such joint interchangeable mileage tickets as with regard to other joint rates, fares, and charges referred to in that section.

It is unlawful for any carrier that has issued any such joint interchangeable mileage tickets to demand, collect, or receive from any person or persons a greater or less compensation for transportation of persons or baggage under such joint interchangeable mileage tickets than that required by the rate, fare, or charge specified in the copies of the joint tariff of rates, fares, or charges filed with the Commission in force at the time.

Charitable institutions.-A charitable institution, as the term bears upon the right of carriers to issue free transportation, is one that is administered in the public interest, and not for private gain. The definition includes hospitals, almshouses, orphanages, asylums, and missionary societies. Such an institution does not necessarily lose its charitable character from the fact that it is under the management of a particular denomination or sect, or because a charge is collected from some or all of those who enjoy its privileges. It is necessary only that it be conducted in the public interest and not for private gain. ${ }^{1}$

Clergymen acting as editors of officially recognized church papers, as college presidents or professors, as financial agents for a church or other religious or charitable institution (including educational institutions under

${ }^{2}$ Passes to Clergymen and Others, 15 I. C. C. 45, 46. 
church goverument), as workers in Christian Temperance or Y. M. C. A. work, and as brothers of religious orders, are included among those who receive reducedrate transportation. Sisters of charity devoting their entire time to religious work and who habitually wear a garb distinctive of their order are not excluded from the privilege of receiving reduced-rate transportation. A clergyman does not lose his ministerial standing by reason of the fact that he leaves the pastorate for some other field of religious activity.

Returned shipments.-Very often the carriers publish low rates on returned shipments or on second-hand or returned goods. The Commission instituted an inquiry into the legality of tariff rules providing for the application of reduced rates on such returned shipments. Under some of the tariffs these reduced rates applied during any time up to four years. It was held that returnedshipment rates in general should be disapproved, but that reduced rates for the return of freight which has been refused by the consignee at destination may properly be made. In the latter case, the return movement is practically a continuation of the going movement and may for that reason be accorded lower than standard rates. Goods in closed packages may lawfully enjoy return-shipment rates if tendered to the carrier within ten days following delivery. While this concession is a slight departure from legal theory, it is doubtless essential if the rule is to be thoroughly workable. ${ }^{2}$

The fact that freight has been shipped once and paid one way cannot be taken into consideration in fixing charges for a subsequent transaction. The principle underlying the ordinary transit privilege cannot be relied upon in support of the return-shipment rule. Transit arrangements, in their most common form at least, are

'Reduced Rates on Returned Shipments, 19 I. C. C. 409, 417. 
susceptible of defense only upon the theory that the inbound movements are, in fact, parts of a single continuous transaction. While the freight is delayed at the transit point the shipment is merely suspended temporarily, the present intention of the shipper being to forward the goods to their ultimate destination. Once let it be conceded that the inbound and outbound movement are separate and distinct and the impropriety of applying any rates other than the regularly established locals would be self-evident. It is clear that there is no real connection between an outbound shipment today and a returned shipment one year hence. There is no room whatever for the argument that the shipment is suspended during the period intervening between the two transactions, for there is no present intent to accomplish the return movement. It is, therefore, impossible to relate the two services and urge the one as a reason for granting special terms to the other. ${ }^{3}$

'Reduced Rates on Returned Shipments, 19 I. C. C. $409,417$. 


\section{SECTION 23}

Jurisdiction of United States courts.-Section 23 provides that the district courts of the United States shall have jurisdiction upon the relation of any persons, firm, or corporation, alleging such violation by a common carrier, of any of the provisions of the Act as prevents the relator from having interstate traffic moved by said common carrier at the same rates as are charged, or upon terms or conditions as favorable as those given by said common carrier for like traffic under similar conditions to any other shipper, to issue a writ or writs of mandamus against said common carrier, commanding such common carrier to move and transport the traffic, or to furnish cars or other facilities for transportation for the party applying for the writ. ${ }^{1}$

\section{SECTION 24}

The Interstate Commerce Commission.-Section 24, which amends Section 11, enlarges the Interstate Commerce Commission to consist of seven members with terms of seven years, each to receive $\$ 10,000$ compensation annually.

${ }^{1}$ For further provisions noncerning the power of the United States courts, see the District Couri Jurisdiction Act, at the end of this treatise. 


\section{MISCELLANEOUS ACTS}

It will be noted that there are other acts that in some way bear upon the Act to Regulate Commerce. As most of these are not of general interest to traffic men, they will be treated very briefly.

It should be remembered, however, that while some of these acts are not of great importance to traffic men in general, others bear upon particular phases of the handling of traffic, or upon important matters in connection with transportation. This is true particularly of such acts as the Safety Appliance Act and the Hours of Service Act.

\section{District Court Jurisdiction Act}

This act abolishes what was known as the commerce court. The commerce court was created in 1910 to take care of appeals from the Interstate Commerce Commission. It was deemed advisable in 1913 to abolish this court and provide that appeals from or a review of the decision the Interstate Commerce Commission should go to the various United States district courts. The act contains certain limitations on the power of the district court by providing that no interlocutory ${ }^{1}$ injunction restraining an order of the Commission shall be granted unless heard by three judges after five days' notice to the Commission. There are also other provisions concerning procedure, which are of interest chiefly to lawyers.

${ }^{1}$ Temporary. 


\section{Compulsory Testimony Act}

This act provides that no person shall be excused from attending and testifying or from producing books, papers, tariffs, contracts, agreements, and documents, before the Interstate Commerce Commission, or in obedience to the subpoena of the Commission, whether such subpoena be signed or issued by one or more Commissioners, or in any cause or proceeding, criminal or otherwise, based upon or growing out of any alleged violation of the Interstate Commerce Act on the ground or for the reason that the testimony or evidence, documentary or otherwise, required of him, may tend to criminate him or subject him to a penalty or forfeiture. But no per'son shall be prosecuted or subjected to any penalty or forfeiture for or on account of any transaction, matter, or thing concerning which he may testify, or produce evidence, documentary or otherwise, before said Commission, or in obedience to its subpoena, or the subpoena of either of them, or in any such case or proceeding. A person, so testifying, however, is not exempt from prosecution and punishment for perjury committed in so testifying.

It further provides that any person who shall neglect or refuse to attend and testify, or to answer any lawful inquiry, or to produce books, papers, tariffs, contracts, agreements, and documents, if it is in his power to do so, in obedience to the subpoena or lawful requirement of the Commission, shall be guilty of an offense and upon conviction thereof by a court of competent jurisdiction, he shall be punished by fine not less than $\$ 100$, or by imprisonment for not more than one year, or by both such fine and imprisonment. 


\section{ElkiNs ACT}

This act is to be construed in connection with the Interstate Commerce Act. It provides penalties for various offenses arising from interstate commerce, in addition to those prescribed in the Interstate Commerce Act.

It provides that anything done or omitted to be cione by a corporation common carrier subject to the Interstate Commerce Act which, if done or omitted to be done by any director or officer thereof, or any receiver, trustee, lessee, agent, or person acting for or employed by such corporation, would constitute a misdemeanor under that Act or under this act, shall also be held to be a misdemeanor committed by such corporation, and upon conviction thereof, the corporation shall be subject to like penalties as are prescribed in the Interstate Commerce Act or by this act with reference to such persons, except such penalties as are changed by this act.

The willful failure upon the part of any carrier to file and publish the tariffs or rates and charges as required by the Interstate Commerce Act or strictly to observe such tariffs until changed according to law, is a misdemeanor. The guilty corporation is subject to a fine of not less than $\$ 1,000$ and not more than $\$ 20,000$ for each offense.

It is made unlawful for any person, persons, or corporation to offer, grant, or give, or to solicit, accept, or receive any rebate, concession, or discrimination in respect to the transportation of any property in interstate or foreign commerce by any common carrier whereby any such property shall by any device whatever be transported at a less rate than that named in the tariffs published and filed by such carrier, as is required by the Interstate Commerce Act, or whereby any other advantage is given or discrimination is practiced. Every person or corpo- 
ration, whether carrier or shipper, who shall, knowingly, offer, grant, or give, or solicit, accept, or receive any such rebates, concession, or discrimination, is guilty of a misdemeanor, and subject to a punishment of not less than $\$ 1,000$ and not more than $\$ 20,000$. In addition to the fine provided for, the guilty person is liable to imprisonment in the penitentiary for a term of not exceeding two years, or both such fine and imprisonment, in the discretion of the court.

\section{Expediting Act}

This act provides that any suit in equity pending in any circuit court of the United States under the Interstate Commerce Act or the Sherman Act, or any other act having a like purpose that may be enacted, in which the United States is complainant, the Attorney-General may file with the clerk of such court a certificate that, in his opinion, the case is of general public importance and thereupon such case shall be given precedence over others, in every way expedited, and assigned for hearing at the earliest practicable day.

\section{Parcel Post Act}

The Parcel Post Act gives to the postmaster the right, subject to the consent of the Interstate Commerce Commission, to change the classification of articles. It provides that in the classification of mailable articles. as well as the weight limit, the rates of postage, zone or zones, and other conditions of mailability under the Act, if the Postmaster-General shall find on experience that they or any of them are such as to prevent the shipment of articles desirable, or permanently to render the cost of the service greater than the receipts of the revenue 
therefrom, he is authorized, subject to the consent of the Interstate Commerce Commission after investigation, to leform from time to time such classification, weight limit, rates, zone or zones or conditions, or any one of them, in order to promote the service to the public or to insure the receipt of revenue from such service adequate to pay the cost thereof.

\section{Boiler Inspection Act}

This act provides that it is unlawful for any common carrier, its officers, or agents, subject to this act, to use any locomotive engine propelled by steam power in moving interstate or foreign traffic unless the boiler of such locomotive and appurtenances thereof are in proper condition and safe to operate in the service to which the same is put, that the same may be employed in the active service of such carrier in moving traffic without unnecessary peril to life or limb. All boilers shall be inspected from time to time in accordance with the provisions of this act, and be able to withstand such test or tests as may be prescribed in the rules and regulations hereinafter provided for. The act then creates a department of boiler inspection and provides for the appointment of inspectors. It further provides that carriers must maintain rules and instructions for the inspection of locomotive boilers and must file such rules with the chief inspector and with the Interstate Commerce Commission.

While this act is quite long, it is simple. The reader will find it printed in the appendix, and should give it the same careful study which he should give all the acts amendatory or supplemental to the Interstate Commerce Act. 


\section{Safety Appliance Act}

This act provides that it is unlawful for any carrier engaged in interstate commerce by railroad to use on its line any locomotive engine in moving interstate traffic not equipped with a power driving-wheel brake and appliances for operating the train-brake system; or to run any train in such traffic after said date that has not a sufficient number of cars in it so equipped with power or train-brakes that the engineer on the locomotive drawing such train can control its speed without requiring brakemen to use the common hand-brake for that purpose.

It further provides that it is unlawful for any such common carrier to haul or permit to be hauled or used on its line any car employed in moving interstate traffic not equipped with couplers automatically by impact, and which can be uncoupled without the necessity of men going between the ends of the cars. This act also contains a great many other provisions concerning safety appliances. The reader is referred to the appendix, where the act itself is printed.

\section{Block Signal Act}

This act provides that the Interstate Commerce Commission is directed to investigate and report on the use of and necessity for block-signal systems and appliances for the automatic control of railway trains in the United States. For this purpose, the Commission is authorized to employ persons who are familiar with the subject, and may use such of its own employes as are necessary to make a thorough examination into the matter. ${ }^{2}$

'Public Resolution, No. 46, approved June 30, 1906. 


\section{Monthly Reports of Accidents Act}

This act provides that it is the duty of the general manager, superintendent, or other proper officer of every common carrier engaged in interstate or foreign commerce by railroad to make to the Interstate Commerce Commission, at its office in Washington, District of Columbia, a monthly report, under oath, of all collisions, derailments, or other accidents resulting in injury to persons, equipment, or roadbed, arising from the operation of such railroad under such rules and regulations as may be prescribed by said Commission. This report shall state the nature and causes thereof and the circumstances connected therewith.

The Interstate Commerce Commission is given authority to investigate all collisions, derailments, or other accidents resulting in serious injury to person or to the property of a railroad occurring on the line of any common carrier engaged in interstate or foreign commerce by railroad.

\section{Hours of Service Act}

This act provides that it is unlawful for any common carrier subject to the Act, or its officers or agents, to require or permit any employe to be or remain on duty for a longer period than sixteen consecutive hours. When. ever any such employe of such common carrier shall have been continuously on duty for sixteen hours, he shall be relieved and not required or permitted again to go on duty until he has had at least ten consecutive hours off duty. No such employe who has been on duty sixteen hours in the aggregate in any twenty-four-hour period shall be required or permitted to continue again to go on duty without having had at least eight consecutive hours 
off duty. Except in case of emergency, no operator, train dispatcher, or other employe, who by the use of the telegraph or telephone dispatches reports, transmits, receives, or delivers orders pertaining to or affecting train movements, shall be required or permitted to be or remain on duty for a longer period than nine hours in any twenty-four-hour period in all towers, places, and stations continuously operated night and day; nor for a longer period than thirteen hours in all towers, offices, places, and stations operated only during the daytime.

\section{Transportation of Explosives Act}

This act provides that specified explosives are not to be carried on passenger vehicles and gives to the Interstate Commerce Commission authority to make regulations for the transportation of explosives. 


\section{TEST QUESTIONS}

These questions are for the student to use in testing his knowledge of the assignment. The answers should be written out, but are not to be sent to the University.

\section{SECTION 1}

1. Mention the more important classes of carriers to which the Act to Regulate Commerce applies.

2. If a shipment moving from one point in a state to another point in the same state passes out of the state in moving between the two points, is it deemed an interstate shipment within the meaning of the Act?

3. When were pipe lines made common carriers by the Act?

4. What is meant by adjacent foreign country?

5. What did the United States Supreme Court say in the Shreveport case relative to state rates which were so low as to discriminate against interstate rates?

6. (a) What is meant by the term "railroad" as defined in the Act? (b) What does the term "transportation" include?

7. Mention some of the elements which are considered in fixing a reasonable rate.

8. What is the authority of the Interstate Commerce Commission over freight classification?

9. What authority has the Commission over bills of lading?

10. (a) Into what three general classes may facilities be divided? (b) What authority has the Commission over them?

11. What are the provisions of Section 1 of the Act as to free transportation?

12. (a) What is meant by the commodities clause? (b) What was the decision of the United States Supreme Court relative to this clause?

13. What authority is given to the Commission relative to ordering the installation of switch connections?

\section{Section 2}

1. How does the discrimination specified in Section 2 of the Act compare with that specified in Section 3 ?

2. Give a brief definition of a rebate. 


\section{Section 3}

1. (a) Give very briefly the provisions of Section 3 of the Act. (b) Mention five important matters which may be governed by this section.

2. May a carrier as a shipper over the lines of another carrier have any preference?

3. In the application of transportation charges, what is said as to discrimination by a carrier against a point to which its line of road does not extend?

4. What is the effect of competition in justifying discrimination?

5. What effect may potential competition have in warranting discrimination? tition?

6. May the Commission compel a carrier to meet compe-

7. What is said as to water competition in warranting discrimination?

8. What provision is made in Section 3 relative to the interchange of facilities?

9. (a) Under Section 3, may carriers be compelled to give their terminal facilities to a competitor? (b) What is the effect if the carriers voluntarily give the use of their terminals to some competitor?

\section{SECTION 4}

1. What is the substance of Section 4 of the Act as it relates to the making of a greater charge for a shorter than for a longer haul?

2. (a) What authority is given to the Commission to authorize the carriers to violate the fourth section? (b) To what extent are such exceptions made?

3. May a carrier in competition with a water route reduce its rates to or from competitive points and then increase such rates if the water competition is eliminated?

\section{SECTION 5}

1. What does Section 5 provide relative to the pooling of freight?

2. What changes were made in Section 5 of the Act by the Panama Canal Act?

\section{SECTION 6}

1. What jurisdiction over tariffs is given to the Commission by Section 6 ? 
2. What provision is made in this section as to publication of tariffs?

3. What is said in Section 6 relative to the necessity of adhering to published rates?

4. What penalty is provided for an erroneous quotation by earriers?

5. What provision is made in Section 6 as to the posting of tariffs?

6. Where are the regulations of the Interstate Commerce Commission relative to the construction of tariffs to be found?

7. (a) Upon what notice may tariffs ordinarily become effective? (b) What authority rests with the Commission relative to allowing rates to bccome effective upon less than regular notice?

8. May carriers engage in the transportation of passengers or property without regularly published rates filed with the Interstate Commerce Commission?

9. What penalty is provided for failure or refusal on the part of a carrier or its representative to comply with the regulations provided under the provisions of Section 6 ?

10. How was Section 6 amended by the Panama Canal Act?

\section{Section 7}

1. What provision is made in Section 7 as to continuous carriage?

\section{Section 8}

1. What provision is made in Section 8 as to the recovery of attorneys' fees?

\section{Section 9}

1. What does Section 9 provide relative to the summoning of witnesses?

\section{Section 10}

1. What is the substance of Section 10 as to penalties for violation of the Act?

SECTION 11

1. Under Section 11, may anyone having any connection with a common carrier be a Commissioner? 
Section 12

1. What authority is given to the Interstate Commerce Commission by Section 12 of the Act?

\section{SECTION 13}

1. (a) Under Section 13 of the Act, who may make complaint to the Commission? (b) State briefly what action the Commission takes after complaints have been filed with it.

2. What authority is given the Commission as to making investigations on its own motion?

\section{SECTION 14}

1. What action must the Commission take after it has made an investigation of any matter?

\section{SECTION 15}

1. Why is Section 15 such an important part of the Act?

2. What authority is given to the Commission by Section 15 to adjust rates, classifications, or other matters which it deems to be unsatisfactory or in violation of some one or more portions of the Act?

3. What is said as to the necessity of action by the Commission before a matter may be carried to the courts?

4. Under what conditions are the orders of the Commission not final?

5. Upon what grounds may an order which is apparently regular be set aside?

6. Mention some of the factors which the Commission may consider in the adjustment of a single rate.

7. Has the Commission any jurisdiction over capitalization?

8. What jurisdiction has the Commission over the suspension of rates?

9. When a transportation service is rendered without tariff authority, what action may the Commission take?

10. What jurisdiction has the Commission over divisions?

11. What power is given to the Commission relative to advanced rates?

12. Mention some of the conditions which may warrant an increase in rates.

13. In determining whether a rate is reasonable or not, of what value is the fact that it has been in effect for many years?

14. What jurisdiction has the Commission over joint rates and through routes? 
15. What is said as to the right of the carrier to favor its own line in the routing of traffic?

16. How may a satisfactory through route be determined?

17. What are the rights of the carrier as to withdrawal of through routes?

18. What is the obligation of carriers to furnish equipment?

19. What provision is made in Section 15 as to the shipper's right to route his traffic?

20. What provisions are made as to the carrier's liability for misrouting freight when the shipper does not furnish routing instructions and when such instructions are furnished?

21. What authority has the Commission over electric lines?

22. What is said in Section 15 relative to the disclosing of business secrets by employes of carriers?

23. What authority has the Commission over allowances to shippers for performing various services?

24. Mention three services for which the carriers quite often make allowances.

25. How may an allowance become a rebate?

\section{SeCtion 16}

1. In Section $\mathbf{1 6}$ what authority is given to the Commission relative to the awarding of reparation?

2. What action is necessary before a shipper can obtain relief from a violation of the Act?

3. What action is necessary before an award of damages can be made for the collection of an unreasonable rate?

4. What is said as to the authority of the Commission to award damages for violation of the Act?

5. What is said as to the necessity of first paying the tariff rate before reparation can be recovered?

6 . Who are entitled to recover damages?

7. What is meant by the Statute of Limitations in connection with the Act?

8. (a) What is a formal complaint? (b) What is an informal complaint?

9. When the Commission awards reparation and the carriers refuse to pay the reparation, what action must be taken?

10. What provision is made as to the rehearing of cases decided by the Commission?

SECTION 17

1. What are the provisions of Section 17 as to procedure before the Commission? 
2. State very briefly the various steps in the handling of a complaint.

3 . Where can the rules of procedure to be followed before the Commission be found?

\section{SeCtion 18}

1. In Section 18 what authority is given to the Commission as to the conduct of its work?

\section{Section 19}

1. Where is the principal office of the Interstate Commerce Commission?

2. What provision is made in Section $\mathbf{1 9}$ for holding hearings at other points than Washington, D. C.?

\section{Section 20}

1. Mention some important matters on which the Commission may require reports from the carriers.

2. What power has the Commission over the keeping of carriers' accounts?

3. What has the Commission said as to the responsibility of accounting officers in connection with the keeping of carriers' accounts correctly?

4. What is the substance of the Carmack Amendment?

5. Do claims for damage arising under the Carmack Amendment come under the jurisdiction of the Interstate Commerce Commission?

6. What jurisdiction have state courts in enforcing the Carmack Amendment?

7. What is the responsibility of the initial carrier for loss or damage under the Carmack Amendment?

8. What is said as to the restriction of liability by this amendment?

9. May the carrier release itself from liability for loss or damage occurring from its own negligence?

10. May carriers legally insert in a bill of lading a provision that claims must be filed within a specified time?

\section{SECTION 21}

1. (a) By what date should the annual report of the Commission be filed? (b) What information ought to be given in this report? 


\section{SECTION 22}

1. What is the substance of Section 22 relative to free transportation and reduced rates?

SECTION 23

1. What authority is given to the United States district courts by Section 23 ?

\section{SeCtion 24}

1. What salary for Interstate Commissioners is provided by Section 24 ?

2. How many Commissioners are provided for?

\section{Miscellaneous Acts}

1. What is the substance of the Compulsory Testimony Act?

2. What penalties are provided by the Elkins Act?

3 . What are the important provisions in the Hours of Service Act? 





\section{THE ACT}

TO

\section{REGULATE COMMERCE}

( AS AMENDED)

ALSO

DISTRICT COURT JURISDICTION ACT

COMPULSORY TESTIMONY ACT

IMMUNITY OF WITNESSES ACT

ELKINS ACT

EXPEDITING ACT

CLAYTON ANTITRUST ACT (Secs. 2, 3, 7-11, 15-19, 26)

GOVERNMENT-AIDED RAILROAD AND TELEGRAPH ACT

LAKE ERIE AND OHIO RIVER SHIP CANAL ACT (Sec. 17)

PARCEL POST ACT (Sec. 8)

SAFETY APPLIANCES

MONTHLY REPORTS OF ACCIDENTS

MEDALS OF HONOR

HOURS OF SERVICE

ASH PAN

TRANSPORTATION OF EXPLOSIVES

BOILER INSPECTION

BLOCK SIGNALS

PUBLISHED BY THE INTERSTATE COMMERCE COMMISSION

REVISED TO NOVEMBER 1, 1914

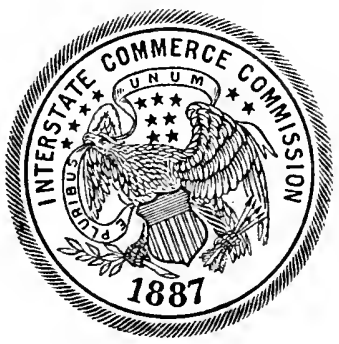

WASHINGTON

GOVERNMENT PRINTING OFFICE 



\section{CONTENTS.}

(Showing citations.)

An act to regulate commerce. aiproved February 4, 1887, and in effect April 5, 1887 (24 Statutes at Large, 379), as amended by an act approved March 2, 1889 ( 25 Statutes at Large, 855). by an act approved February 10, 1891 ( 26 Statutes at Large, 743 ), by an act approved February 8, 1895 (28 Statutes at Large. 643), by an act approved June 29, 1906 (34 Statutes at Large, 584), by a joint resolution approved June 30, 1906 (34 Statutes at Large, 838), by an act approved April 13. 1908 (35 Statutes at Large, 60), by an act approved February 25, 1909 (35 Statutes at Large. 648), by an act approved June 18, 1910 (36 Statutes at Large, 539), by an act approved Angust 24, 1912 (37 Statutes at Large, 566), and by an act approved Narch 1, 1913 (37 Statutes at Large, 701)

An act in relation to testimony before the Interstate Commerce Commission; and in cases or proceedings nuder or connected with an act entitled an act to regulate commerce, and amendments thereto, approved February 11, 1893 (27 Statutes at Litrge, 433)

Page.

An act defining the right of immmnity of witnesses under the act entitled an act in relation to testimony before the Interstate Commerce 'Ccanmission, and so forth. approved February 11, 1893, and an act entitled an act to establish the Department of Commerce and Labor, approved February 14, 1903, and an act entitled an act to further regulate commerce with foreign nations and anong the states, approved February 19,1903 , and an act entitled an act making appropriations for the legislative, executive, and judicial expenses of the Government for the fiscal year ending June 30, 1904, and for other purposes, approved February 25, 1903. Approved June 30, 1906 (34 Statutes at Large. 798)

An act to further regulate commerce with foreign uations and among the States, approved February 19, 1903 (32 Statutes at Large. 847), as amended by an act approved June 29, 1906 (34 Statutes at Large, 584) - All act to expedite the hearing and determination of suits in equity pending or hereafter brought under the act of July 2. 1890, entitled an act to protect trade and commerce against unlawful restraints and monopolies, an act to regulate commerce, or any other acts having a like purpose that may be hereafter enacted, approred February 11, 1903 (32 Statutes at Large, 823), as amended by an act approved June 25. 1910 (36 Statutes at Large, 854) 
An act supplementary to the act of July 1, 1S62, entitled an act to aid in the construction of a railroad and telegraph line from the Missouri River to the Pacific Ocean, and to secure to the Gorernment the use of the same for postal, militiry. and other purposes. and also of the act of July 2. 1864, and other acts amendatory of said first-named act; ap-

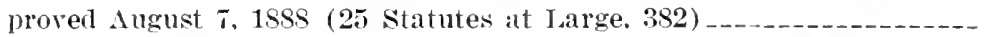

In act to incorporate the Lalke Erie and Ohio River Ship Canal, to define the powers thereof, and to ficilitite interstite rommerce, approved June 30, 1906 (34 Statutes at Iarge, so9)

An act making alprolriations fol the service of the Post Office Department for the fiscal year ending .June 30, 1913, and for other purposes. approved August 24. 1912 (37 Statutes at Large. 558)

In act miling aprropriations to supply urgent teficiencies in appropriations for the fiscal year 1913, and for other purposes. approved October 22, 1913 (3s Statutes at Large, 219)

An act to amend an act entitled "An act to codify, revise, and amend the laws relating to the judiciary," approved IIarch 3, 1911, being chapter 231 of 'Thirty-sixth Niatutes at Large. approved January 20, 1914 (38 Statites at Lallige. 27S)

An act making alpropriations for sundry ciril expenses of the Government for the fiscal year euding June 30, 1915, and for other purposes, approved August 1. 1914 (38 Statutes at Large. 627)

An act to promote the safety of employees and travelers upon railroads by compelling common carriers engaged in interstate commerce to equip their cars with automatic couplers and continnous brakes. and their locomotives with driving-wheel brakes. and for other purposes, approved Iarch 2. 1 \$93 (27 statutes at Ialrge. 531), as amended hy an act approved April 1. 186\%; (29 Statutes al Large. 85)

Au act to ament in arct entitlerl an act to promote the safety of employees and travelers. and so forth. approved March 2. 1893, and amended April 1, 1896; approved 11 arch 2. 1903 (32 Statutes at Large. 943) _....... An act to supplement an act to proniote the sitety of employees and trarelers uron railroads by compelling common carriers engaged in interstate commerce to equip their cars with automatic rouplers and continuous brakes, ind their locomotives with driving-wheel brakes. and for other purposes, and other safety-appliance acts, and for other purjoses. approred April 14, 1910 (36 Statutes at Large, 298) ; also amendment of March 4. 1911 (36 Statutes at Large. 1397)

An atet authorizing the Commission to employ safety-apliance inspectors. approved June 2S, 1902 (32 Statutes at Large, 444) _._.............

An act requiring rommon carriers engaged in interstate and forejgn commerce to make full reports of all accidents to the Interstate Commerce Commission and authorizing investigations thereof by sild Commission. approved May 6, 1910 ( 36 Statutes at Ial ree, 950 )

An act to promote the security of travel upon railroads engaged in interstate commerce, and to encourage the saving of life. approved February 23, 1905, (3:) Statutes at Large. 743 ), and regulations prescribed thereunder

An act to promote the safety of employees and travelers upon railroads by limiting the hours of service of employees thereon. approved March 4. 1907 (34 Statutes at Iarge, 1415) 
An act to promote the safety of employees on railroads, approved May 30. 1908 (35 Statutes at Large, 476)

An act to promote the safe transportation in interstate commerce of explosives and other dangerous articles. and to provicle penalties for its violation, approved March 4, 1909 (35 Statutes at Large, 1134)_._...-

An act to promote the siffely of employees and trivelers upon railroads by compelling common carriers engaged in interstate commerce to equip their locomotives with safe and suitable boilers and appurtenances thereto, approved February 17, 1911 (36 Statutes at Large, 913) An act making appropriations to supply urgent deficiencies in appropriations for the fiscal year 1913, and for other purposes, approved October 22, 1913 (38 Statutes at Lalige, 219)

An act to supplement existing law's agaiust unlawful restraints and monopolies, and for other purposes, approved October 15. 1914 (38 Statutes at Large, 730 )

Joint resolution directing the Interstate Commerce Commission to investigate and report on block-signal systems and appliances for the automatic control of railway trains, approved June 30 . 1906 (:it Statutes at Large, 838 ) 

THE ACT TO REGULATE COMMERCE AS AMENDED.

Be it enacted by the Senate and House of Representatives of the United States of America in Congress assembled,

SEC. 1. (As amended June 29, 1906, A pril 13, 1908, and Carriers and June 18, 1910.) That the provisions of this Act shall ap- subject to the ply to any corporation or any person or persons engaged in the transportation of oil or other commodity, except water and except natural or artificial gas, by means of pipe lines, or partly by pipe lines and partly by railroad, or partly by pipe lines and partly by water, and to tele- Telegraph, graph, telephone, and cable companies (whether wire or oleble compawireless) engaged in sending messages from one State, Territory, or District of the United States, to any other State, Territory, or District of the United States, or to any foreign country, who shall be considered and held to be common carriers within the meaning and purpose of this Act, and to any common carrier or carriers engaged in the transportation of passengers or property wholly by ${ }_{\text {Rairroads and }}$ railroad (or partly by railroad and partly by water when both are used under a common control, management, or arrangement for a continuous carriage or shipment), from one State or Territory of the United States or the District of Columbia, to any other State or Territory of the United States or the District of Columbia, or from one place in a Territory to another place in the same Territory, or from any place in the United States to an adjacent foreign country, or from any place in the United States through a foreign country to any other place in the United States, and also to the transportation in like manner of property shipped from any place in the United States to a foreign country and carried from such place to a port of transshipment, or shipped from a foreign country to any place in the United States and carried to such place from a port of entry either in the United States or an adjacent foreign country: Provided, however, That the provisions sct does not of this Act shall not apply to the transportation of pas. popply to trans. sencen 
age, or handling of property wholly within one State and not shipped to or from a foreign country from or to any State or Territory as aforesaid, nor shall they apply to the transmission of messages by telephone, telegraph, or cable wholly within one State and not transmitted to or from a foreign country from or to any State or Territory as aforesaid.

Express com. The term "common carrier" as used in this Act shall pan les and sleeping car include express companies and sleeping car companies. companies in " The term "railroad" as used in this Act shall include all
cluded. What the
term $\mathrm{rm}$. rall-bridges and ferries used or operated in connection with
road" Includes. any railroad, and also all the road in use by any corporation operating a railroad, whether owned or operated under a contract, agreement, or lease, and shall also include all switches, spurs. tracks, and terminal facilities of every kind used or necessary in the transportation of the persons or property designated herein, and also all freight depots, yards, and grounds used or necessary in the transportation or delivery of any of said property; what the and the term "transportation" shall include cars and term "transcludes. shipment or carriage, irrespective of ownership or of any contract, express or implied, for the use thereof and all services in connection with the receipt, delivery, elevation, and transfer in transit, rentilation, refrigeration or icing, storage, and handling of property transported; and it shall be the duty of every carrier subject to the provisions of this Act to provide and furnish such transportation upon reasonable request therefor, and to establish through routes and just and reasonable rates applicable thereto; and to provide reasonable facilities for operating such through rontes and to make reasonable rules and regulations with respect to the exchange, interchange, and return of cars used therein, and for the operation of such through routes, and providing for reasonable compensation to those entitled thereto.

Charges must All charges made for any service rendered or to be be just and reayonable. rendered in the transportation of passengers or property and for the transmission of messages by telegraph, telephone, or cable, as aforesaid, or in connection therewith, shall be just and reasonable: and every unjust and unreasonable charge for such service or any part thereof is prohibited and declared to be unlawful: Provided, That messages by telegraph, telephone, or cable, subject to the provisions of this Act, may be classified into day, night, 
repeated, unrepeated, letter, commercial, press, Government, and such other classes as are just and reasonable, and different rates may be charged for the different classes of messages: And provided further, That nothing in this Act shall be construed to prevent telephone, telegraph, and cable companies from entering into contracts with common carriers, for the exchange of services.

And it is hereby made the duty of all common carriers subject to the provisions of this Act to establish, observe, and enforce just and reasonable classifications of property just and reafor transportation, with reference to which rates, tariffs, regulations, or practices are or may be made or prescribed, and just and reasonable regulations and practices affecting classifications, rates, or tariffs, the issuance, form, and substance of tickets, receipts, and bills of lading, the manner and method of presenting, marking, packing, and delivering property for transportation, the facilities for transportation, the carrying of personal, sample, and excess baggage, and all other matters relating to or connected with the receiving, handling, transporting, storing, and delivery of property subject to the provisions of this Act which may be necessary or proper to secure the safe and prompt receipt, handling, transportation, and delivery of property subject to the provisions of this Act upon just and reasonable terms, and every such unjust and unreasonable classification, regulation, and practice with reference to commerce between the States and with foreign countries is prohibited and declared to be unlawful.

No common carrier subject to the provisions of this Free passes Act shall, after January first, nineteen hundred and seven, portatton prodirectly or indirectly, issue or give any interstate free ticket, free pass, or free transportation for passengers, except to its employees and their families, its officers, agents, surgeons, physicians, and attorneys at law; to Excepted ministers of religion, traveling secretaries of railroad Young Men's Christian Associations, inmates of hospitals and charitable and eleemosynary institutions, and persons exclusively engaged in charitable and eleemosynary work; to indigent, destitute, and homeless persons, and to such persons when transported by charitable societies or hospitals, and the necessary agents employed in such transportation; to inmates of the National Homes or State Homes for Disabled Volunteer Soldiers, and of Soldiers' and Sailors' Homes, including those about to enter and 
those returning home after discharge; to necessary care takers of live stock, poultry, mills, and fruit; to employees on sleeping cars, express cars, and to linemen of telegraph and telephone companies; to Railway Mail Service employees, post-office inspectors, customs inspectors, and immigration inspectors: to newsboys on trains, baggage agents, witnesses attending any legal investigation in which the common carrier is interested, persons injured in wrecks and physicians and nurses attending Interchange such persons: Provinled. That this provision shall not be

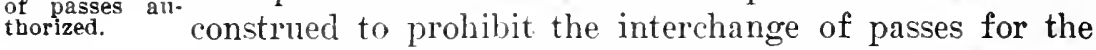
officers. agents. and employees of common carriers, and their families; nor to prohibit any common carrier from carrying passengers free with the object of providing relief in cases of general epidemic, pestilence, or other calamitous visitation: And provided further, That this provision shall not be construed to prohibit the privilege of passes or franks, or the exchange thereof with each other, for the officers, agents, employees, and their families of such telegraph, telephone, and cable lines, and the officers, agents, employees and their families of other common carriers subject to the provisions of this Act: Pro"What terms vided further. That the term "employees" as used in "emp "familles" this paragraph shall include furloughed, pensioned, and inciude. superannuated employees, persons who have become disabled or infirm in the service of any such common carrier, and the remains of a person killed in the employment of a carrier and ex-employees traveling for the purpose of entering the service of any such common carrier; and the term "families" as used in this paragraph shall include the families of those persons named in this proviso, also the families of persons killed, and the widows during widowhood and minor children during minority of persons who died, while in the service of any such common Jurisdiction carrier. Any common carrier violating this provision

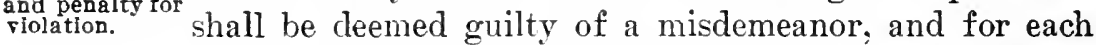
offense, on conviction, shall pay to the United States a penalty of not less than one hundred dollars nor more than two thousand dollars, and any person, other than the persons excepted in this provision, who uses any such interstate free ticket, free pass, or free transportation shall be subject to a like penalty. Jurisdiction of offenses under this provision shall be the same as that provided for offenses in an Act entitled "An Act to further regu- 
late commerce with foreign nations and among the States," approved February nineteenth, nineteen hundred and three, and any amendment thereof. (See section 22.)

From and after May first, nineteen hundred and eight, $\underset{\text { ciause. }}{\text { Commodities }}$ it shall be unlawful for any railroad company to transport from any State, Territory, or the District of Columbia, to any other State, Territory, or the District of Columbia, or to any foreign country, any article or commodity, other than timber and the manufactured products thereof, manufactured, mined, or produced by it, or under its authority, or which it may own in whole or in part, or in which it may have any interest, direct or indirect, except such articles or commodities as may be necessary and intended for its use in the conduct of its business as a common carrier.

Any common carrier subject to the provisions of this Act, upon application of any lateral, branch line of railroad, or of any shipper tendering interstate traffic for transportation, shall construct, maintain, and operate

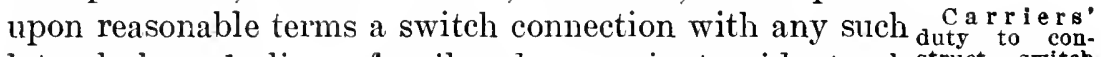
lateral, branch line of railroad, or private side track struct switch which may be constructed to connect with its railroad, where such connection is reasonably practicable and can be put in with safety and will furnish sufficient business to justify the construction and maintenance of the same; and shall furnish cars for the movement of such traffic to the best of its ability without discrimination in favor of or against any such shipper. If any common carrier shall fail to install and operate any such switch or connection as aforesaid, on application therefor in writing by any shipper or owner of such lateral, branch line of railroad, such shipper or owner of such lateral, branch line of railroad may make complaint to the Commission, as provided in section thirteen of this Act, and the Commission shall hear and investigate the same and shall determine as to the safety and practicability thereof and justification and reasonable compensation therefor, and the Commission may make an order, as provided in sec- Switch contion fifteen of this Act, directing the common carrier to be ordered by comply with the provisions of this section in accordance sion. with such order, and such order shall be enforced as hereinafter provided for the enforcement of all other orders by the Commission, other than orders for the payment of money. 
SEc. 2. That if any common carrier subject to the provisions of this Act shall, directly or indirectly, by any special rate, rebate, drawback, or other device, charge, demand, collect, or receive from any person or persons a greater or less compensation for any service rendered, or to be rendered. in the transportation of passengers or property, subject to the provisions of this act, than it charges, demands, collects, or receives from any other

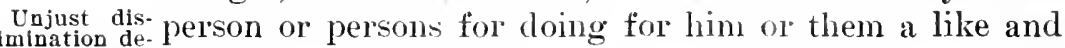
flined and for-
bldenten. lind of traffic under substantially similar circumstances and conditions. such common carrier shall be deemed guilty of unjust discrimination, which is hereby prohibited and declared to be unlaw ful.

Ser. 3. That it shall be unlawful for any common carrier subject to the provisions of this act to make or give

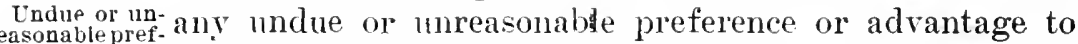
erence or ad- any particular person, company, firm, corporation, or
vantage forbidden.

locality, or any particular description of traffic, in any respect whatsoever, or to subject any particular person, company, firm, corporation, or locality, or any particular description of traffic, to any undue or unreasonable prejudice or disadvantage in any respect whatsoever.

Every common carrier subject to the provisions of this Act shall, according to their respective powers, afford all Faclltities for
terchange of reasonable, proper, and equal facilities for the intertraffic. change of traffic between their respective lines, and for the receiving, forwarding, and delivering of passengers and property to and from their several lines and those Discrimina- connecting therewith, and shall not discriminate in their con $n$ e $c$ t in $\mathrm{g}$ rates and charges between such connecting lines; but this lines forbidden. shall not be coustrued as requiring any such common carrier to give the use of its tracks or terminal facilities to another carrier engaged in like business.

Sec. 4. (As amended June 18, 1910.) That it shall be unlaw ful for any common carrier subject to the provisions of this Act to charge or receive any greater compensation in the aggregate for the transportation of pasL o $\mathrm{g}$ a n a sengers, or of like kind of property, for a shorter than for whort haul provision.

a longer distance over the same line or route in the same direction, the shorter being included within the longer distance, or to charge any greater compensation as a through route than the aggregate of the intermediate rates subject to the provisions of this Act; but this shall not be construed as authorizing any common carrier with- 
in the terms of this Act to charge or receive as great compensation for a shorter as for a longer distance: Provided, however, That upon application to the Interstate Com- Commission merce Cormission such common carrier may in special to s authority

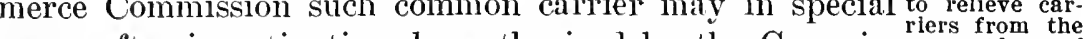
cases, after investigation, be authorized by the Commis- reper from the sion to charge less for longer than for shorter distances for the transportation of passengers or property; and the Commission may from time to time prescribe the extent to which such designated common carrier may be relieved from the operation of this section: Provided further, That no rates or charges law fully existing at the time of the passage of this amendatory Act shall be required to be changed by reason of the provisions of this section prior to the expiration of six months after the passage of this Act, nor in any case where application shall have been filed before the Commission, in accordance with the provisions of this section, until a determination of such application by the Commission.

Whenever a carrier by railroad shall in competition $\begin{gathered}\mathrm{R} a \mathrm{tes} \text { re. } \\ \text { reed to }\end{gathered}$ with a water route or routes reduce the rates on the car-water compettriage of any species of freight to or from competitive raised wot be points, it shall not be permitted to increase such rates unless after hearing by the Interstate Commerce Commission it shall be found that such proposed increase rests upon changed conditions other than the elimination of water competition.

SEc. 5. (As amended August 94, 1912.) That it shall be unlawful for any common carrier subject to the provisions of this Act to enter into any contract, agreement, or combination with any other common carrier or carriers for the pooling of freights of different and competing rooing of railroads, or to divide between then the aggregate or net vision of earnproceeds of the earnings of such railroads, or any portion thereof; and in any case of an agreement for the pooling of freights as aforesaid, each day of its continnance shall be deemed a separate offense.

From and after the first day of July, nineteen hundred Amend ment and fourteen, it shall be unlawful for any railroad com- 1912 . pany or other common carrier subject to the Act to regulate commerce to own, lease, operate, control, or have any interest whatsoever (by stock ownership or otherwise, to Rairroads not either directly, indirectly, through any holding company, peting water or by stockholders or directors in common, or in any other manner) in any common carrier by water operated 
through the Panama Canal or elsewhere with which said railroad or other carrier aforesaid does or may compete for traffic or any vessel carrying freight or passengers upon said water route or elsewhere with which said railroad or other carrier aforesaid does or may compete for Penalts. traffic; and in case of the riolation of this provision each day in which such riolation continues shall be deemed a separate offense.

Commission Jurisdiction is hereby conferred on the Interstate Comas to competi- merce Commission to determine questions of fact as to
tion. the competition $\mathrm{ol}^{*}$ possibility of competition, after full hearing, on the application of any railroad company or other carrier. Such application may be filed for the purpose of determining whether any existing service is in violation of this section and pray for an order permitting the continuance of any ressel or ressels already in operation, or for the purpose of asking an order to install new service not in conflict with the provisions of this paragraph. The Commission may on its orn motion or the application of any shipper institute proceedings to inquire into the operation of any ressel in use by any railroad or other carrier which has not applied to the Commission and had the question of competition or the possibility of Orders to be competition determined as herein provided. In all such
fnal. cases the order of said Commission shall be final.

Commission's
authority to al- If the Interstate Commerce Commission shall be of the low ownership opinion that any such existing specified service by water
of certain vesof certain res- $\begin{aligned} & \text { sel } \\ & \text { rallroads. }\end{aligned}$
by other than through the Panama Canal is being operated in the interest of the public and is of advantage to the conrenience and commerce of the people, and that such extension will neither exclude, prevent, nor reduce competition on the ronte by water under consideration, the Interstate Commerce Commission may, by order, extend the time during which such service by water may continue to be operated beyond July first, nineteen hundred and Rates of such fourteen. In every case of such extension the rates,
rater carriers to be filed schedules, and practices of such water carrier shall be sion. Commis- filed with the Interstate Commerce Commission and shall be subject to the Act to regulate commerce and all amendments thereto in the same manner and to the same extent as is the railroad or other common carrier controlling such water carrier or interested in any manner in its operation: Provided, Any application for extension under the terms of this provision filed with the Interstate Commerce Commission prior to July first, nineteen hundred and fourteen, 
but for any reason not heard and disposed of before said date, may be considered and granted thereafter.

No vessel permitted to engage in the coastwise or for- violators of eign trade of the United States shall be permitted to enter not to $\mathbf{u}_{\mathbf{u}} \mathbf{c} \mathbf{c}$ or pass through said canal if such ship is owned, chartered, operated, or controlled by any person or company which is doing business in violation of the provisions of the Act of Congress approved July second, eighteen hundred and ninety, entitled "An Act to protect trade and commerce against unlawful restraints and monopolies;" or the provisions of sections serenty-three to serentyseven, both inclusive, of an Act approved August twentyseventh, eighteen hundred and ninety-four, entitled "An Act to reduce taxation, to provide revenue for the Government, and for other purposes," or the provisions of any other Act of Congress amending or supplementing the said Act of July second, eighteen hundred and ninety, commonly known as the Sherman Antitrust Act, and amendments thereto, or said sections of the Act of August twenty-seventh, eighteen hundred and ninety-four. The question of fact may be determined by the judgment of any court of the United States of competent jurisdiction in any cause pending before it to which the owners or operators of such ship are parties. Suit may be brought by any shipper or by the Attorney General of the United States.

SEc. 6. (Amended March 2, 1889. Following section substituted June 29, 1906. Amended June 18, 1910, and August 24, 1912.) That every common carrier subject to the provisions of this Act shall file with the Commission created by this Act and print and keep open to public inspection schedules showing all the rates, fares, and charges for transportation between different points on its own route and between points on its own route and points on the route of any other carrier by railroad, by pipe line, or by water when a through route and joint rate have been established. If no joint rate orer the through route has been established, the several carriers in such through route shall file, print and keep open to Printing and public inspection as aforesaid, the separately established posting of sules of $_{\text {rates, fares, and }}$ rates, fares and charges applied to the through trans- charges Includportation. The schedules printed as aforesaid by any regulations and such common carrier shall plainly state the places be-same,icing, the tween which property and passengers will be carried, and age, and terml. shall contain the classification of freight in force, and classificationat. 
shall also state separately all terminal charges, storage charges, icing charges, and all other charges which the Commission may require, all privileges or facilities granted or allowed and any rules or regulations which in any wise change, affect, or determine any part or the aggregate of such aforesaid rates, fares, and charges, or the value of the service rendered to the passenger, shipper, or consignee. Such schedules shall be plainly printed in large type, and copies for the use of the public shall be kept posted in two public and conspicuous places in every depot, station, or office of such carrier where passengers or freight, respectively, are received for transportation, in such form that they shall be accessible to the public and can be conveniently inspected. The provisions of this section shall apply to all traffic, transportation, and facilities defined in this Act.

Printing and Any common carrier subject to the provisions of this
posting of sched ues of
rates on freight $A$ ct receiving freight in the United States to be carried carried through through a foreign country to any place in the United
a foreign coun. through

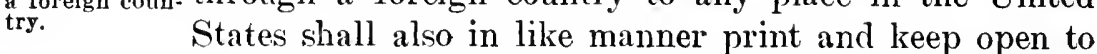
public inspection, at every depot or office where such freight is received for shipment, schedules showing the through rates established and charged by such common carrier to all points in the United States beyond the forFreight sub- and any freight shipped from the United States through eign country to which it accepts freight for shipment; duties in case of failure to pub-a foreign country into the United States the through rate lish th r o u gh on which shall not have been made public, as required by
rates.

this Act, shall, before it is admitted into the United States from said foreign country, be subject to customs duties as if said freight were of foreign production.

'Thirty days' public notice of change in rates

No change shall be made in the rates, fares, and charges or joint rates, fares, and charges which have been filed and published by any common carrier in compliance with the requirements of this section, except after thirty days' notice to the Commission and to the public published as aforesaid, which shall plainly state the changes proposed to be made in the schedule then in force and the time when the changed rates, fares, or charges will go into effect; and the proposed changes shall be shown by printing new schedules, or shall be plainly indicated upon the schedules in force at the time and kept open to public inspection: Provided, That the Commission may, in its discretion and for good cause shown, allow changes upon 
less than the notice herein specified, or modify the re- $\begin{gathered}\text { Commission } \\ \text { mas modify re- }\end{gathered}$ quirements of this section in respect to publishing, post-quirements of ing, and filing of tariffs, either in particular instances or by a general order applicable to special or peculiar circumstances or conditions.

The names of the several carriers which are parties to Joint tariffs and specify any joint tariff shall be specified therein, and each of the names of carparties thereto, other than the one filing the same, shall pating. file with the Commission such evidence of concurrence currence.

therein or acceptance thereof as may be required or approved by the Commission, and where such evidence of concurrence or acceptance is filed it shall not be necessary for the carriers filing the same to also file copies of the tariffs in which they are named as parties.

Every common carrier subject to this Act shall also file Copies of conwith said Commission copies of all contracts, agreements, ments, or arwh said Comns, rangements reor arrangements with other common carriers in relation lating to traffic to any traffic affected by the provisions of this Act to with Commis- $_{\text {sion }}$ which it may be a party.

The Commission may determine and prescribe the for'm $\begin{gathered}\text { Commission } \\ \text { a prescrlbe }\end{gathered}$ in which the schedules required by this section to be kept forms of scbedopen to public inspection shall be prepared and arranged and may change the form from time to time as shall be found expedient.

No carrier, unless otherwise provided by this Act, shall Nocarrier engage or participate in the transportation of passengers $\begin{gathered}\text { transportation } \\ \text { unless } 1 t \text { files }\end{gathered}$ or property, as defined in this Act, unless the rates, fares, $\underset{\text { andes, fares.and }}{\text { and }}$ and charges upon which the same are transported by said charges therecarrier have been filed and published in accordance with the provisions of this Act; nor shall any carrier charge or demand or collect or receive a greater or less or different compensation for such transportation of passengers or property, or for any service in connection therewith, between the points named in such tariffs than the rates. rubiished fares, and charges which are specified in the tariff filed strictis ob. and in effect at the time; nor shall any carrier refund or remit in any manner or by any device any portion of the rates, fares, and charges so specified, nor extend to any shipper or person any privileges or facilities in the transportation of passengers or property, except such as are specified in such tariffs: Provided, That wherever the "Carrler" word "carrier" occurs in this Act it shall be held to mean mon carrier."

"common carrier."

$66170^{\circ}-14 \longrightarrow$ 
Preference and expedition of $\mathrm{military}$ itrecedence shall, upon the demand of the President of of war.

the United States, be given, orer all other traffic, to the transportation of troops and material of war, and carriers shall adopt every means within their control to facilitate and expedite the military traffic.

The Commission may reject and refuse to file any Amendmentschedule that is tendered for filing which does not pro1910. vide and give lawful notice of its effective date, and any commissionschedule so rejected by the Commission shall be void and ma r r ject. certain sched-its use shall be unlawful.

ules.

In case of failure or refusal on the part of any carrier, receiver, or trustee to comply with the terms of any regulation adopted and promulgated or any order made by the Commission under the provisions of this section, such Penalty 1 or carrier, receiver, or trustee shall be liable to a penalty of pailure to comlation.

dollars for each and every day of the continuance of such offense, which shall accrue to the United States and may be recorered in a civil action brought by the United States.

$\underset{\text { Carrier to }}{\tan }$ If any common carrier subject to the provisions of this

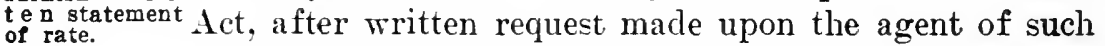
carrier hereinafter in this section referred to, by any person or company for a written statement of the rate or charge applicable to a described shipment between stated places under the schedules or tariffs to which such carrier is a party, shall refuse or omit to give such written statement within a reasonable time, or shall misstate in writing the applicable rate, and if the person or company making such request suffers damage in consequence of such refusal or omission or in consequence of the misPenalty torstatement of the rate, either through making the ship$m$ isstatement
of rate. higher than the rate over another a vailable line or route, or through entering into any sale or other contract whereunder such person or company obligates himself or itself to make such shipment of freight at his or its cost, then the said carrier shall be liable to a penalty of two hundred and fifty dollars, which shall accrue to the United States and may be recovered in a civil action brought by the United States.

Name of car-
er's agent to shall be the duty of every carrier by railroad to keep be posted. at all times conspicuously posted in every station where 
freight is received for transportation the name of an agent resident in the city, village, or town where such station is located, to whom application may be made for the information by this section required to be furnished on written request; and in case any carrier shall fail at any time to have such name so posted in any station, it shall be sufficient to address such request in substantially the following form: "The Station Agent of the

Company at - Station," together with the name of the proper post office, inserting the name of the carrier company and of the station in the blanks, and to serve the same by depositing the request so addressed, with postage thereon prepaid, in any post office.

When property may be or is transported from point to Amendment point in the United States by rail and water through the 1912 .

Panama Canal or otherwise, the transportation being by a common carrier or carriers, and not entirely within the limits of a single State, the Interstate Commerce Com- $\begin{gathered}\text { Commission } \\ \text { a s jurisdic- }\end{gathered}$ mission shall have jurisdiction of such transportation tion orer rail and of the carriers, both by rail and by water, which may fic in certain or do engage in the same, in the following particulars, in addition to the jurisdiction given by the Act to regulate commerce, as amended June eighteenth, nineteen hundred and ten:

(a) To establish physical connection between the lines Phssical conof the rail carrier and the dock of the water carrier by tween rail lines directing the rail carrier to make suitable connection be- water carriers. tween its line and a track or tracks which hare been constructed from the dock to the limits of its right of way, or by directing either or both the rail and water carrier, individually or in connection with one another, to construct and connect with the lines of the rail carrier a spur track or tracks to the dock. This prorision shall only apply where such connection is reasonably practicable, can be made with safety to the public, and where the amount of business to be handled is sufficient to justify the outlay.

The Commission shall have full authority to determine commission the terms and conditions upon which these connecting terms and contracks, when constructed, shall be operated, and it may, struction and either in the construction or the operation of such tracks, determine what sum shall be paid to or by either carrier. The provisions of this paragraph shall extend to cases 
where the dock is owned by other parties than the carrier involved.

Th rough routesand joint rates between rail and water carriers.

Proportional erom ports.

Throug h routes and joint

rates between rall and water commerce enters into arrangements with any water carcarliers from a lier operating from a port in the United States to a forto a foreign eign country. through the Panama Canal or otherwise, for canal. $\quad$ i the handling of through business between intelior points cf the United States and such foreign country, the Interstate Commerce Commission may require such railway to enter into similar arrangements with any or all other lines of steamships operating from said port to the same foreign country.

l'roceedings before the Com mission to enforce thes amendments.
The orders of the Interstate Commerce Commission relating to this section shall only be made upon formal complaint or in proceedings instituted by the Commission of its own motion and after full hearing. The orders provided for in the two amendments to the Act to regulate commerce enacted in this section shall be serred in the same manner and enforced by the same penalties and proceedings as are the orders of the Commission made under the provisions of section fifteen of the Act to regulate commerce. as amended June eighteenth, nineteen hundred arid ten, and they may be conditioned for the payment of any sum or the giring of security for the payment of any sum or the discharge of any obligation which may be required by the terms of said order.

SEC. 7. That it shall be unlawful for any common carrier subject to the provisions of this Act to enter into any combination, contract, or agreement, expressed or im- 
plied, to prevent, by change of time schedule, carriage in different cars, or by other means or devices, the carriage of freights from being continuous from the place of shipment to the place of destination; and no break of bulk, stoppage, or interruption made by such common carrier shall prevent the carriage of freights from being and being treated as one continuous carriage from the place of shipment to the place of destination, unless such break, be treated as
stoppage, or interruption was made in good faith for less stouppage in
in sood falth some necessary purpose, and without any intent to aroid or unnecessarily interrupt such continuous carriage or to evade any of the prorisions of this Act.

SEC. 8. That in case any common carrier subject to the provisions of this Act shall do, cause to be done, or permit to be done any act, matter, or thing in this Act prohibited or declared to be unlawful, or shall omit to do any act, matter, or thing in this Act required to be done, such common carrier shall be liable to the person or persons injured thereby for the full amount of damages sustained common carjured thereby for the full amount of damages sustamed riers for damin consequence of any such riolation of the provisions of vios cansed by this Act, together with a reasonable comsel or attorney's this act. fee, to be fixed by the court in erery case of recorery. which attorney's fee shall be taxed and collected as part of the costs in the case.

Sec. 9. That any person or persons claiming to be damaged by any common carrier subject to the provisions of claiming to be this Act may either make complaint to the Commission as to complain to bereinafter provided for, or may bring suit in his or their sion or m or is. own behalf for the recorery of the damages for which Su it in in a such common carrier may be liable under the provisions of this Act, in any district or circuit court of the United States of competent jurisdiction; but such person or persons shall not have the right to pursue both of said remedies, and must in each case elect which one of the two methods of procedure herein provided for he or they will adopt. In any such action brought for the recorery of damages the court before which the same shall be pending may compel any director, officer, receirer. trus- oficers of tee, or agent of the corporation or company defendant be compented to in such suit to attend, appear, and testify in such case, testify, but and may compel the production of the books and papers of such corporation or company party to any such suit; the claim that any such testimony or evidence may tend to criminate the person giving such evidence shall not excuse such witness from testifying; but such evidence 
or testimony shall not be used against such person on the trial of any criminal proceeding.

Penalties for SEc. 10. (As amended Warch \&, 1889, and June 18, violations of
Act by carriers, 1910.) That any common carrier subject to the provisions or wen the of this Act, or, whenerer such common carrier is a corcorporation, its
offcers, agents. poration, any director or officer thereof, or any receiver, or employees:
Fine and im-tristee, lessee, agent. or person acting for or employed by prisonment. such corporation, who, alone or with any other corporation, company. person, or party, shall willfully do or cause to be done, or shall willingly suffer or permit to be done, any act, matter, or thing in this Act prohibited or declared to be mnlawful, or who shall aid or abet therein, or shall willfully omit or fail to do any act, matter, or thing in this Act required to be done, or shall cause or willingly suffer or permit any act, matter, or thing so directed or required by this Act to be done not to be so done, or shall aid or abet any such omission or failure, or shall be guilty of any infraction of this Act for which no penalty is otherwise provided, or who shall aid or abet therein, shall be deemed guilty of a misdemeanor, and shall, upon conriction thereof in any district court of the United States within the jurisdiction of which such offense was committed, be subject to a fine of not to exceed five thousand dollars for each offense: Provided, That if the offense for which any person shall be convicted as aforesaid shall be an unlawful discrimination in rates, fares. or charges for the transportation of passengers or property, such person shall, in addition to the fine hereinbefore provided for, be liable to imprisonment in the penitentiary for a term of not exceeding two rears, or both such fine and imprisonment, in the discretion of the court.

Penalties for false billing, etc., by car- Act. or, whenerer such common carrier is a corporation, riers, their offi-
cers or agents : any officer or agent thereof: or any person acting for or Fine and im. employed by such corporation, who, by means of false
prisonment.

billing. false classification, false weighing, or false report of teight. or by any other derice or means, shall knowingly and willfully assist, or shall willingly suffer or permit. any person or persons to obtain transportation for property at less than the regular rates then established and in force on the line of transportation of such common carrier. shall be deemed guilty of a misdemeanor, and shall, upon conviction thereof in any court of the United States of competent jurisdiction within the district in 
which such offense was committed, be subject to a fine of not exceeding five thousand dollars, or imprisonment in the penitentiary for a term of not exceeding two years, or both, in the discretion of the court, for each offense.

Any person, corporation, or company, or any agent or Penalties for officer thereof, who shall deliver property for transporta- etc., bs $\mathrm{bshl}_{\mathrm{p}}$. offcer thereof, who shall deliver property for transporta- pers and other tion to any common carrier subject to the provisions of persons: Fine this Act, or for whom, as consignor or consignee, any ment. such carrier shall transport property, who shall knowingly and willfully, directly or indirectly, himself or by employee, agent, officer, or otherwise, by false billing, false classification, false weighing, false representation of the contents of the package or the substance of the property, false report of weight, false statement, or by any other device or means, whether with or without the consent or connivance of the carrier, its agent, or officer, obtain or attempt to obtain transportation for such property at less than the regular rates then established and in force on the line of transportation; or who shall knowingly and willfully, directly or indirectly, himself or by employee, agent, officer, or otherwise, by false statement or representation as to cost, value, nature, or extent of injury, or by the use of any false bill, bill of lading, receipt, voucher, roll, account, claim, certificate, affidavit, or deposition, knowing the same to be false, fictitious, or fraudulent, or to contain any false, fictitious, or fraudulent statement or entry, obtain or attempt to obtain any allowance, refund, or payment for damage or otherwise in connection with or growing out of the transportation of or agreement to transport such property, whether with or without the consent or connirance of the carrier, whereby the compensation of such carrier for such transportation, either before or after payment, shall in fact be made less than the regular rates then established and in force on the line of transportation, shall be deemed guilty of fraud, which is hereby declared to be a misdemeanor, and shall, upon conviction thereof in any court of the United States of competent jurisdiction within the district in which such offense was wholly or in part committed, be subject for each offense to a fine of not exceeding five thousand dollars or imprisonment in the penitentiary for a term of not exceeding two years, or both, in the discretion of the court: Provided, That the penalty of imprisonment shall not apply to artificial persons. 
Penalties for If any such person, or any officer or agent of any such
aduclng com. induclng comto discriminate unfustly: Fine other thing of value, solicitation, or otherwise, induce or ment. Joint attempt to induce any common carrier subject to the procarrle r forvisions of this Act, or any of its officers or agents, to disdamages. criminate unjustly in his, its, or their favor as against any other consignor or consignee in the transportation of property, or shall aid or abet any common carrier in any such unjust discrimination, such person or such officer or agent of such corporation or company shall be deemed guilty of a misdemeanor, and shall, upon conviction thereof in any court of the United States of competent jurisdiction within the district in which such offense was committed, be subject to a fine of not exceeding five thousand dollars, or imprisomment in the penitentiary for a term of not exceeding two years, or both, in the discretuon of the court, for each offense; and such person, corporation, or company shall also, together with said common carrier, be liable, jointly or severally, in an action to be brought by any consignor or consignee discriminated against in any court of the United States of competent jurisdiction for all damages caused by or resulting therefrom.

Interstate Sec. 11. That a Commission is hereby created and esCommlssion-tablished to be known as the Interstate Commerce Comers-method or miscion, which shall be composed of five Commiscioners appointment mission, which shall be composed of five Commissioners,
and terms. who shall be appointed by the President, by and with the advice and consent of the Senate. The Commissioners first appointed under this Act shall continue in office for the term of two, three, four, five, and six years, respectively, from the first day of January; Anno Domini eighteen hundred and eighty-seven, the term of each to be designated by the President; but their successors shall be appointed for terms of six years, except that any person chosen to fill a vacancy shall be appointed only for the unexpired time of the Commissioner whom he shall succeed. Any Commissioner may be removed by the President for inefficiency, neglect of duty, or malfeasance in office. Not more than three of the Commissioners shall be appointed from the same political party. No person in the employ of or loolding any official relation to any common carrier subject to the provisions of this Act, or owning stock or bonds thereof, or who is in any manner. pecuniarily interested therein, shall enter upon the duties of or hold such office. Said Commissioners shall not en- 
gage in any other business, rocation, or employment. No vacancy in the Commission shall impair the right of the remaining Commissioners to exercise all the powers of the Commission. (See section 24, enlarging Commission. and increasing salaries.)

SEc. 12. (As amended March 2,1889 , and February 10, Commisston 1891.) That the Commission hereby created shall have business of carauthority to inquire into the management of the business itself informed of all common carriers subject to the provisions of this thereto.

Act, and shall keep itself informed as to the manner and method in which the same is conducted, and shall have commission the right to obtain from such common carriers full and enforce provl. complete information necessary to enable the Commission Act.

to perform the duties and carry ont the objects for which it was created; and the Commission is hereby authorized and required to execute and enforce the provisions of this Act; and, upon the request of the Commission, it shall be the duty of any district attorney of the United States Districtattorto whom the Commission may apply to institute in the cute under alproper court and to prosecute under the direction of the torney Generai. Attorney General of the United States all necessary proceedings for the enforcement of the provisions of this Act and for the punishment of all violations thereof, and the costs and expenses of such prosecution shall be paid out of the appropriation for the expenses of the courts of the United States; and for the purposes of this Act the Com- Commission mission shall have power to require, by subpona, the at- may require tendance and testimony of witnesses and the production documentary of all books, papers, tariffs, contracts, agreements, and documents relating to any matter under investigation.

Such attendance of witnesses, and the production of courts to such documentary evidence, may be required from any nesses toattend place in the United States, at any designated place of hearing. And in case of disobedience to a subpœna the Commission, or any party to a proceeding before the Commission, may inroke the aid of any court of the United States in requiring the attendance and testimony of witnesses and the production of books, papers, and documents under the provisions of this section.

And any of the circuit courts of the United States within the jurisdiction of which such inquiry is carried on may, in case of contumacy or refusal to obey a subpœna issued to any common carrier subject to the provisions of this Act, or other person, issue an order requiring such common carrier or other person to appear before 
said Commission (and produce books and papers if so ordered) and gire evidence touching the matter in question: and ans failure to obes such order of the court may claim that be punished by such court as a contempt thereof. The terdesce will claim that any such testimons or eridence may tend to nate will not criminate the person giring such eridence shall not excuse ercuse ritness. such witness from testifring: but such evidence or testimony shall not be used against such person on the trial of an criminal proceeding.

Depositions. The testimon of ant witness mar be taken, at the instance of a party. in ans proceeding or inrestigation pending before the Commission. by deposition, at any time after a cause or proceeding is at issue on petition and commission answer. The Commission may also order testimony to be timon to taken by deposition in ans proceeding or inrestigation situ pending before it. at ans stage of such proceeding or inrestigation. Such depositions may be taken before any judge of any court of the United States. or any commissioner of a circuit. or ans clerk of a district or circuit court. or any chancellor. justice. or judge of a supreme or superior court. mayor or chief magistrate of a city, judge of a county court. or court of common pleas of any of the Lnited States. or any notary public, not being of counsel or attorner to either of the parties. nor interested in the erent of the proceeding or investigation. Reasonable notice most first be giren in writing by the party or his attorney proposing to take such deposition to the opposite party or his attorner of record. as either may be nearest. Which notice shall state the name of the witness and the time and place of the taking of his deposition. Any person may be compelled to appear and depose, and to produce documentart eridence, in the same manner as witnesses mar be compelled to appear and testify and prodnce documentary evidence before the Commission as hereinbefore provided.

Evert person deposing as herein provided shall be cautioned and sworn (or affirm. if he so request) to testify the whole truth. and shall be carefully examined. His testimony shall be reduced to writing br the magistrate taking the deposition. or under his direction, and shall, after it has been reduced to writing, be subscribed by the deponent.

If a witness whose testimony may be desired to be taken br deposition be in a foreign country, the deposition mar be taken before an officer or person designated by the 
Commission, or agreed upon by the parties br stipulation in writing to be filed with the Commission. All depositions must be promptly filed with the Commission.

Witnesses whose depositions are taken pursuant to this Fees of ritAct, and the magistrate or other officer taking the same. shall severally be entitled to the same fees as are paid for like serrices in the courts of the Cnited States.

SEc. 13. (As amended June 18. 1910.) That any per- Complaints to

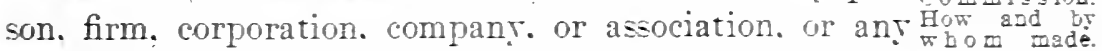

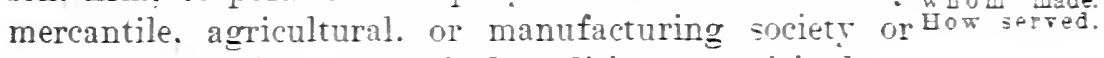
other organization, or ans body politic or municipal organization. or an common carrier. complaining of anything done or omitted to be done br any common carrier subject to the prorisions of this Act. in contrarention of the prorisions thereof. may apply to said Commission by petition. which shall briefly state the facts: whereupon a statement of the complaint thus made shall be formarded by the Commission to such common carrier. who shall be called upon to satisfy the complaint. or to ansmer the same in mriting. within a reasonable time. to be specified by the Commission. If such common carrier within the time specified shall make reparation for the injurs alleged to have been done. the common carrier shall be relieved of liability to the complainant only for the particular riolation of law thus complained of. If such carrier or carriers shall not satisf the complaint within the cretion as to time specified. or there shall appear to be ant reasonable restigation. ground for inrestigating said complaint. it shall be the duty of the Commission to investigate the matters complained of in such manner and br such means as it shall deem proper.

Said Commission shall. in like manner and with the same authoritr and porters. inrestigate ans complaint forwarded br the railroad commissioner or railroad commission of ans State or Territor th at the request of such commissioner or commission. and the Interstate Com- Commission merce Commission shall hare full authority and potrer ders in investiat anr time to institute an inquirr. on its oirn motion. in on its own moans case and as to any matter or thing concerning which tion.

a complaint is authorized to be made. to or before said Commission br ant prorision of this Act. or concerning which any question may arise under ans of the prorisions of this Act. or relating to the enforcement of any of the prorisions of this Act. And the said Commission shall hare the same powers and authority to proceed with 
any inquiry instituted on its own motion as though it had been appealed to by complaint or petition under any of the provisions of this Act, including the power to make ard enforce any order or orders in the case, or relating to the matter or thing concerning which the inquiry is - had excepting orders for the payment of money. No complain-complaint shall at any time be dismissed because of the ant's interest
immaterial.

SEc. 14. (Amended Warch 2, 1889, and June 29, 1906.)

Commission That whenever an investigation shall be made by said must report, Commission, it shall be its duty to make a report in writclusions and ing in respect thereto, which shall state the conclusions of
order. the Commission, together with its decision, order, or reReparation. quirement in the premises; and in case damages are a warded such report shall include the findings of fact on which the award is made.

Reports must All reports of investigations made by the Commission be entered of
record. shall be entered of record, and a copy thereof shall be fur-
ice of copies on ice of copies on
parties. common carrier that may have been complained of.

Reports and decisions to be published, and be competent
as evidence.

The Commission may proride for the publication of its reports and decisions in such form and manner as may be best adapted for public information and use, and such anthorized publications shall be competent evidence of the reports and decisions of the Commission therein contained in all courts of the United States and of the several States without any further proof or anthentication thereof.

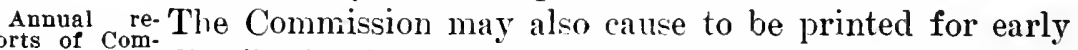
ports of
mission.

SEc. 15. (As amended June 29, 1906, and June 18, Commission 1910.) That whenever, after full hearing upon a coma nd prescribe plaint made as provided in section thirteen of this Act, or jonable rates after full hearing under an order for investigation and and classifica-
tions to be ob hearing made by the Commission on its own initiative mum charges. (either in extension of any pending complaint or without any complaint whatever), the Commission shall be of opinion that any individual or joint rates or charges whatsoever demanded, charged, or collected by any common carrier or carriers subject to the provisions of this Act for the transportation of persons or property or for the transmission of messages by telegraph or telephone as defined in the first section of this Act, or that any individual or joint classifications, regulations, or practices whatsoever of such carrier or carriers subject to the provisions of this Act are unjust or unreasonable or unjustly 
discriminatory, or unduly preferential or prejudicial or otherwise in violation of any of the provisions of this Act, the Commission is hereby authorized and empowered to Commission determine and prescribe what will be the just and reason- and prescribe able individul or joint rate or rates, charce or charges, sonable regiable individual or joint rate or rates, charge or charges, sonabie regito be thereafter observed in such case as the maximum to practices. be charged, and what individual or joint classification, may order carregulation, or practice is just, fair, and reasonable, to be and desist from prolations thereafter followed, and to make an order that the carrier of found orders or carriers shall cease and desist from such violation to mission effectthe extent to which the Commission finds the same to scribed. but in whic less than exist, and shall not thereafter publish, demand, or collect thirty days. any rate or charge for such transportation or transmission in excess of the maximum rate or charge so prescribed, and shall adopt the classification and shall conform to and observe the regulation or practice so prescribed. All orders in orders of the Commission, except orders for the payment ceed ing two or years, unless of money, shall take effect within such reasonable time, suspended or not less than thirty days, and shall continue in force for commission or such period of time, not exceeding two years, as shall be prescribed in the order of the Commission, unless the same shall be suspended or modified or set aside by the Commission, or be suspended or set aside by a court of competent juriscliction. Whenever the carrier or carriers, $r$ iers fail to in obedience to such order of the Commission or other- agree on diviwise, in respect to joint rates, fares, or charges. shall fail rate, Commission may preto agree among themselves upon the apportionment or scribe propordivision thereof the Commission may, after hearing, rate to be re. division thereof the Commission may, after hearing, ceived by each make a supplemental order prescribing the just and rea carrier.

sonable proportion of such joint rate to be received by each carrier party thereto, which order shall take effect as a part of the original order.

Whenever there shall be filed with the Commission any of nestigation schedule stating a new individual or joint rate, fare, or ules. charge, or any new individual or joint classification, or any new individual or joint regulation or practice affecting any rate, fare, or charge, the Commission shall have, and it is hereby given, authority, either upon complaint or upon its own initiative without complaint, at once, and if it so order's, without answer or other formal pleading by the interested carrier or carriers, but upon reasonable notice, to enter upon a hearing concerning the propriety of such rate, fare, charge, classification, regulation, or practice; and pending such hearing and the decision commission thereon the Commission upon filing with such schedule mew schedules. 
and delivering to the carrier or carriers affected thereby a statement in writing of its reasons for such suspension may suspend the operation of such schedule and defer the use of such rate, fare, charge, classification, regulation, or practice, but not for a longer period than one hundred and twenty days beyond the time when such rate, fare, charge, classification, regulation, or practice would otherwise go into effect; and after full hearing, whether completed before or after the rate, fare, charge, classification, regulation, or practice goes into effect, the Commission may make such order in reference to such rate, fare, charge, classification, regulation, or practice as would be proper in a proceeding initiated after the rate, fare, charge, classification, regulation, or practice had Commission become effective: Provided, That if any such hearing can suspension. not be concluded within the period of suspension, as above stated, the Interstate Commerce Commission may, in its discretion, extend the time of suspension for a furBurden of ther period not exceeding six months. At any hearing
oof on carrier as to rea-involving a rate increased after January first, nineteen increased rates. hundred and ten, or of a rate sought to be increased after the passage of this Act, the burden of proof to show that the increased rate or proposed increased rate is just and reasonable shall be upon the common carrier, and the Commission shall give to the hearing and decision of such questions preference orer all other questions pending before it and decide the same as speedily as possible.

Commission The Commission may also, after hearing, on a comthrough routes plaint or upon its own initiative without complaint, and joint rates
a $\mathrm{d}$ classifica-establish through routes and joint classifications, and
tions. may establish joint rates as the maximum to be charged and may prescribe the division of such rates as hereinbefore provided and the terms and conditions under which such through routes shall be operated, whenever the carriers themselves shall hare refused or neglected to establish voluntarily such through routes or joint classifications or joint rates: and this provision shall apply when one of the connecting carriers is a water line. The Commission shall not, however, establish any through route, classification, or rate between street electric passenger railways not engaged in the general business of transporting freight in addition to their passenger and express business and railroads of a different character, nor shall the Commission have the right to establish any route, classification, rate, fare, or charge when the trans- 
portation is wholly by water, and any transportation by water affected by this Act shall be subject to the laws and regulations applicable to transportation by water.

And in establishing such through route, the Commission $\mathrm{Lim}$ itation shall not require any company, without its consent, to on porcer to embrace in such route substantially less than the entire length of its railroad and of any intermediate railroad operated in conjunction and under a common management or control therewith which lies between the termini of such proposed through route, unless to do so would make such through route unreasonably long as compared with another practicable through route which could otherwise be established.

In all cases where at the time of delivery of property to any railroad corporation being a common carrier. for designate routtransportation subject to the provisions of this Act to any point of destination, between which and the point of such delivery for shipment two or more through routes and through rates shall have been established as in this Act provided to which through routes and through rates such carrier is a party, the person, firm, or corporation making such shipment, subject to such reasonable exceptions and regulations as the Interstate Commerce Commission shall from time to time prescribe, shall have the right to designate in writing by which of such through routes such property shall be transported to destination, and it shall thereupon be the duty of the initial carrier to route said property and issue a through bill of lading therefor as so directed, and to transport said property over its own line or lines and deliver the same to a connecting line or lines according to such through route, and it shall be the duty of each of said connecting carriers to receive said property and transport it orer the said line or lines and deliver the same to the next succeeding carrier or consignee according to the routing instructions in said bill of lading: Provided, however, That the shipper shall in all instances have the right to determine. where competing lines of railroad constitute portions of a through line or route, over which of said competing lines so constituting a portion of said through line or route his freight shall be transported.

It shall be unlawful for any common carrier subject to $\begin{gathered}\text { Onlawful to } \\ \text { to or receive }\end{gathered}$ the provisions of this Act, or any officer, agent, or em-information ployee of such common carrier, or for any other person or ments. corporation lawfully authorized by such common car- 
rier to receive information therefrom, knowingly to disclose to or permit to be acquired by any person or corporation other than the shipper or consignee, without the consent of such shipper or consignee, any information concerning the nature, kind, quantity, destination, consignee, or routing of any property tendered or delivered to such common carrier for interstate transportation, which information may be used to the detriment or prejudice of such shipper or consignee, or which may improperly disclose his business transactions to a competitor; and it shall also be unlawful for any person or corporation to solicit or knowingly receive any such inforExceptions. mation which may be so used: Provided, That nothing in this Act shall be construed to prevent the giving of such information in response to any legal process issued under the authority of any state or federal court, or to any officer or agent of the Govermment of the United States, or of any State or Territory, in the exercise of his powers, or to any officer or other duly authorized person seeking such information for the prosecution of persons charged with or suspected of crime; or information given by a common carrier to another carrier or its duly authorized agent, for the purpose of adjusting mutual traffic accounts in the ordinary course of business of such carriers.

Penalty. Any person, corporation, or association violating any of the provisions of the next preceding paragraph of this section shall be deemed guilty of a misdemeanor, and for each offense, on conviction, shall pay to the United States a penalty of not more than one thousand dollars.

Commission If the owner of property transported under this Act

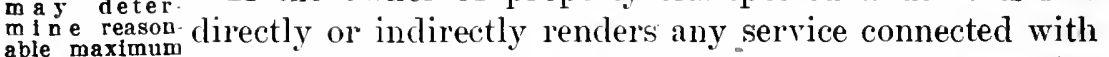
able maximum
to be pald for such transportation, or furnishes any instrumentality
service re servce $r$ en-
dered or in- used therein, the charge and allowance therefor shall be
strumentality strumentality
furnished by no more than is just and reasonable, and the Commission
owner of prop owner of prop
erty prated. $^{-} \mathbf{n}$ - may, after hearing on a complaint or on its own initiative, determine what is a reasonable charge as the maximum to be paid by the carrier or carriers for the services so rendered or for the use of the instrumentality so furnished, and fix the same by appropriate order, which order shall have the same force and effect and be enforced in like manner as the orders above provided for under this section. 
in the making of an order under the provisions of this Act.

SEC. 16. (Amended March 2,1889 , June 29, 1906, and June 18, 1910.) That if, after hearing on a complaint $\begin{gathered}\mathrm{Award} \text { of } \\ \mathrm{damas}\end{gathered}$ made as provided in section thirteen of this Act, the Com-Commission. mission shall determine that any party complainant is entitled to an award of damages under the provisions of this Act for a violation thereof, the Commission shall make an order directing the carrier to pay to the complainant the sum to which he is entitled on or before a day named.

If a carrier does not comply with an order for the pay- $\underset{f \text { or o e d e }}{\mathrm{T}} \underset{\mathrm{b}}{\mathrm{b}} \mathrm{j}$ ment of money within the time limit in such order, the courts. complainant, or any person for whose benefit such order was made, may file in the circuit court of the United States for the district in which he resides or in which is located the principal operating office of the carrier, or through which the road of the carrier runs, or in any state court of general jurisdiction having jurisdiction of the parties, a petition setting forth briefly the causes for which he claims damages, and the order of the Commission in the premises. Such suit in the circuit court of the United States shall proceed in all respects like other mission of comcivil suits for damages, except that on the trial of such incie evidence suit the findings and order of the Commission shall be prima facie evidence of the facts therein stated, and except that the petitioner shall not be liable for costs in the circuit court nor for costs at any subsequent stage of the proceedings unless they accrue upon his appeal. If the petitioner shall finally prevail he shall be allowed a reasonable attorney's fee, to be taxed and collected as a part of the costs of the suit. All complaints for the recovery of damages shall be filed with the Commission within two years from the time the cause of action accrues, and not after, and a petition for the enforcement of an order for the payment of money shall be filed in the circuit court Limltation upon action. or state court within one year from the date.of the order, and not after.

In such suits all parties in whose favor the Commission Joint plainmay have made an award for damages by a single order jofnt may sue may be joined as plaintiffs, and all of the carriers parties on awards of to such order awarding such damages may be joined as defendants, and such suit may be maintained by such joint plaintiffs and against such joint defendants in any district where any one of such joint plaintiffs could main$66170^{\circ}-14-3$ 
tain such suit against any one of such joint defendants; $\mathrm{Ser}$ ice of and service of process against any one of such defendants
process. process. as may not be found in the district where the suit is brought may be made in any district where such defendant carrier has its principal operating office. In case of such joint suit the recovery, if any, may be by judgment in faror of any one of such plaintiffs, against the defendant found to be liable to such plaintiff.

gerrice of Every order of the Commission shall be forthwith order of Commission.

served upon the designated agent of the carrier in the city of Waslington or in such other manner as may be provided by law.

Commission The Commission shall be authorized to suspend or

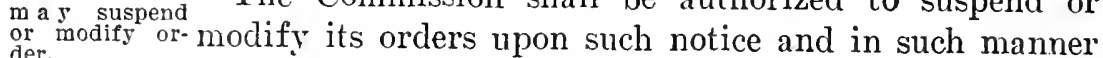
der.

as it shall deem proper.

Carriers, It shall be the duty of every common carrier, its agents and employees and employees, to observe and comply with such orders mus $\mathrm{t}$ comply
with such or- so long as the same shall remain in effect.
ders.

Punishment

Any carrier, any officer, representative, or agent of a b $y$ forfeiture
for refusal to carrier, or any receiver, trustee, lessee, or agent of either
obey order of obey order of under section order made under the provisions of section fifteen of this Act shall forfeit to the United States the sum of five thousand dollars for each offense. Every distinct violation shall be a separate offense, and in case of a continuing violation each day shall be deemed a separate offense.

Forfeiture The forfeiture provided for in this Act shall be payable recorarta ani into the Treasury of the United States, and shall be rerecorerable in
ciril suit. coverable in a civil suit in the name of the United States,

brought in the district where the carrier has its principal operating office, or in any district through which the road of the carrier runs.

Duty of dis- It shall be the duty of the various district attorneys,
act attorneys to prosecute. urider the direction of the Attorney General of the United States, to prosecute for the recovery of forfeiCosts a n a tures. 'The costs and expenses of such prosecution shall expenses to be
pald ont of ap- be paid out of the appropriation for the expenses of the
proprlation for court expenses. courts of the United States.

Commission
aay emplor attorness. necessary for proper legal aid and service of the Commission or its members in the conduct of their work or for proper representation of the public interests in investigations made by it or cases or proceedings pending before it, whether at the Commission's own instance or upon 
complaint, or to appear for and represent the Commission in any case pending in the Commerce Court; and the expenses of such employment shall be paid out of the appropriation for the Commission.

If any carrier fails or neglects to obey any order of the $\begin{gathered}\mathrm{C} \text { o m merce } \\ \text { Court to en- }\end{gathered}$ Commission other than for the payment of money, while force or d e e r s the same is in effect, the Interstate Commerce Commis- payment of sion or any party injured thereby, or the United States, by its Attorney General, may apply to the Commerce Court for the enforcement of such orcler. If, after hearing, that Court determines that the order was regularly made and duly served, and that the carrier is in disobedience of the same, the Court shall enforce obedience to such order by a writ of injunction or other proper process, mandatory or otherwise, to restrain such carrier, its officers, agents, or representatives, from further disobedience of such order, or to enjoin upon it or them obedience to the same.

The copies of schedules and classifications and tariffs $\mathbf{S c b e d u l e s ,}$ of rates, fares, and charges, and of all contracts, agree- annual reports ments, and arrangemonts between common carriers filed fil com wis it h in with the Commission as herein provided, and the statis- ords, receivable tics, tables, and figures contained in the annual or other as primance facie reports of carriers mate to the Commicied copies or reports of carriers made to the Commission as required extracts thereunder the provisions of this Act shall be preserved as pub- facie evidence. lic records in the custody of the secretary of the Commission, and shall be received as prima facie evidence of what they purport to be for the purpose of investigations by the Commission and in all judicial proceedings; and copies of and extracts from any of said schedules, classifications, tariffs, contracts, agreements, arrangements, or reports, made public records as aforesaid, certified by the secretary, under the Commission's seal, shall be received in evidence with like effect as the originals.

SEc. 16a. (Added June 29, 1906.) That after a deci- commission sion, order, or requirement has been made by the Com- may grant remission in any proceeding any party thereto may at any time make application for rehearing of the same, or any matter determined therein, and it shall be lawful for the Commission in its discretion to grant such a rehearing if sufficient reason therefor be made to appear. Applica- Application tions for rehearing shall be governed by such general shall not oper. rules, as the Commission may establish. No such appli- ate as stay of of cation shall excuse any carrier from complo less so ordered cation shall excuse any carrier from complying with or by Commission. obeying any decision, order, or requirement of the Com- 
mission, or operate in any manner to stay or postpone the enforcement thereof, without the special order of the Commission. In case a rehearing is granted the proceedings thereupon shall conform as nearly as may be to the proceedings in an original hearing, except as the Commission may otherwise direct; and if, in its judgment, after such rehearing and the consideration of all facts, including those arising since the former hearing, it shall appear that the original decision, order, or requirement is in any respect unjust or unwarranted, the Commission Commission may rererse, change, or modify the same accordingly. may, on rebear modify order. hearing, reversing, changing, or modifying the original determination shall be subject to the same provisions as an original order.

Commission SEc. 17. (As amended March 2, 1889.) That the Comits own pro- mission may conduct its proceedings in such manner as
cedure.

will best condnce to the proper dispatch of business and to the ends of justice. A majority of the Commission shall constitute a quorum for the transaction of business, but no Commissioner shall participate in any hearing or proceeding in which he has any pecuniary interest. Said Commission may, from time to time, make or amend such general rules or orders as may be requisite for the order and regulation of proceedings before it, including forms of notices and the service thereof, which shall conform, as nearly as may be, to those in use in the courts of the

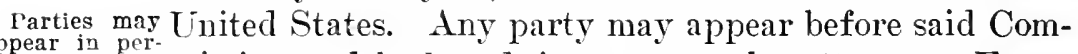
appear in per-
son or by at-mission and be heard. in person or by attorney. Every
tomey. rote and official act of the Commission shall be entered of record, and its proceedings shall be public upon the reofficial seal. quest of either party interested. Said Commission shall have an official seal, which shall be judicially noticed. Either of the members of the Commission may administer oaths and affirmations and sign subpœnas.

SEC. 18. (As amended March ?, 1889.) [See section S4, increasing salaries of Commissioners.] That each Commissioner shall receive an annual salary of seven thousand five hundred dollars, payable in the same manner as the judges of the courts of the United States. The Commission shall appoint a secretary, who shall receive an annual salary of three thousand five hundred dollars, ${ }^{a}$ payable in like manner. The Commission shall have

${ }^{a}$ Increased to $\$ 5,000$ by sundry civil act of March 4, 1907, 34 Stat. L., 1311. 
authority to employ and fix the compensation of such other employees as it may find necessary to the proper performance of its duties. Until otherwise provided by law, the Ccmmission may hire suitable offices for its use, and shall have authority to procure all necessary office supplies. Witnesses summoned before the Commission Witnesses' shall be paid the same fees and mileage that are paid witnesses in the courts of the United States.

All of the expenses of the Commission, including all necessary expenses for transportation incurred by the Commissioners, or by their employees under their orders, in making any investigation, or upon official business in any other places than in the city of Washington, shall be allowed and paid on the presentation of itemized vouchers therefor approved by the chairman of the Commission.

SEc. 19. That the principal office of the Commission Principal ofshall be in the city of Washington, where its general ses- ington. Washsions shall be held; but whenever the convenience of the $\begin{gathered}\text { Sessions of } \\ \text { the Commis- }\end{gathered}$ public or the parties may be promoted, or delay or ex-sion.

pense prevented thereby, the Commission may hold special sessions in any part of the United States. It may, by $\begin{gathered}\text { Commission } \\ \text { masente }\end{gathered}$ one or more of the Commissioners, prosecute any inquiry inquiries by necessary to its duties, in any part of the United States, its members in inta any matter or question of fact pertaining to the busi- United states. ness of any common carrier subject to the provisions of this Act.

SEc. 19a. That the Commission shall, as hereinafter Amendment provided, investigate, ascertain, and report the value of 1913 . all the property owned or used by every common carrier subject to the provisions of this Act. To enable the Com- $\begin{gathered}\text { Investigation } \\ \text { by Commission. }\end{gathered}$ mission to make such investigation and report, it is all- Experts. thorized to employ such experts and other assistants as may be necessary. The Commission may appoint examiners who shall have power to administer oaths, examine witnesses, and take testimony. The Commission shall Classification make an inventory which shall list the property of every common carrier subject to the provisions of this Act in detail, and show the value thereof as hereinafter provided, and shall classify the physical property, as nearly as practicable, in conformity with the classification of expenditures for road and equipment, as prescribed by the Interstate Commerce Commission.

First. In such investigation said Commission shall erty used for ascertain and report in detail as to each piece of property common-carowned or used by said common carrier for its purposes 
as a common carrier, the original cost to date, the cost of reproduction new, the cost of reproduction less depreciation, and an analysis of the methods by which these several costs are obtained, and the reason for their diffel"

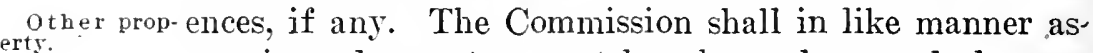
erts. certain and report separately other values, and elements of value, if any, of the property of such common carrier: and an analysis of the methods of valuation employed, and of the reasons for any differences between any such value, and each of the foregoing cost values.

value of real Second. Such investigation and report shall state in property. detail and separately from improvements the original cost of all lands, rights of way, and terminals owned or used for the purposes of a common carrier, and ascer tained as of the time of dedication to public use, and the present value of the same, and separately the original and present cost of condemnation and damages or of purchase in excess of such original cost or present value.

Property held for other than com mon-car
rier purposes.

Third. Such investigation and report shall show sepa-

a common carrier, and the original cost and present value of the same, together with an analysis of the methods of valuation employed.

Corporate or- Fourth. In ascertaining the original cost to date of ganization.

the property of such common carrier the Commission, in addition to such other elements as it may deem necessary, shall investigate and report upon the history and organization of the present and of any previous corporation Stocks a nd operating such property; upon any increases or decreases
bonds. of stocks, bonds, or other securities, in any reorganization; upon moneys received by any such corporation by reason of any issues of stocks, bonds, or other securities; upon the syndicating, banking, and other financial arrangements under which such issues were made and the ex-

Earnings and pense thereof; and upon the net and gross earnings of
xpenditures. such corporations; and shall also ascertain and report in such detail as may be determined by the Commission upon the expenditure of all moneys and the purposes for which the same were expended.

Grants from Fifth. The Commission shall ascertain and report the
Wnited States. amount and value of any aid, gift, grant of right of way, or donation, made to any such common carrier, or to any prerious corporation operating such property, by the Government of the United States or by any State, county, or municipal gorernment, or by individuals, associations, 
or corporations; and it shall also ascertain and report the vaiue of land grants of land to any such common carrier, or any previous corporation operating such property, by the Government of the United States, or by any State, county, or municipal government, and the amount of money derived from the sale of any portion of such grants and the value of the unsold portion thereof at the time acqired and at the present time, also, the amount and value $\begin{gathered}\text { Concessions } \\ \text { made by car- }\end{gathered}$ of any concession and allowance made by such common rier.

carrier to the Government of the United States, or to any State, county, or municipal government in consideration of such aid, gift, grant, or donation.

Except as herein otherwise provided, the Commission Mrocedured of shall have power to prescribe the method of procedure to be followed in the conduct of the investigation, the form in which the results of the valuation shall be submitted, and the classification of the elements that constitute the ascertained value, and such investigation shall show the value of the property of every common carrier as a whole and separately the value of its property in each of the several States and Territories and the District of Columbia, classified and in detail as herein required.

Such investigation shall be commenced within sixty Prosecution days after the approval of this Act and shall be prose- investigation. cuted with diligence and thoroughness, and the result thereof reported to Congress at the beginning of each regular session thereafter until completed.

Every common carrier subject to the provisions of this $\begin{gathered}\text { Documents to } \\ \text { investiga. }\end{gathered}$ Act shall furnish to the Commission or its agents from tion. time to time and as the Commission may require maps, profiles, contracts, reports of engineers, and any other documents, records, and papers, or copies of any or all of the same, in aid of such investigation and determination of the value of the property of said common carrier, and shall grant to all agents of the Commission free Access of access to its right of way, its property, and its accounts, erty. records, and memoranda whenever and wherever requested by any such duly authorized agent, and every common carrier is hereby directed and required to cooperate with and aid the Commission in the work of the valuation of its property in such further particulars and

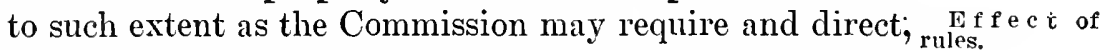
and all rules and regulations made by the Commission for the purpose of administering the provisions of this section and section twenty of this Act shall have the full force and effect of law. Unless otherwise ordered by the Com- 
Public inspec- mission, with the reasons therefor, the records and data of
ion of records. the Commission shall be open to the inspection and examination of the public.

raluation of Upon the completion of the valuation herein provided

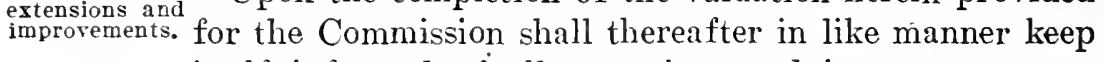
itself informed of all extensions and improvements or other changes in the condition and ralue of the property of all common carriers, and shall ascertain the value thereof, and shall from time to time, revise and correct its valuations, showing such rerision and correction classified and as a whole and separately in each of the several States and Territories and the District of Columbia, Reports towhich raluations, both original and corrected, shall be congress. tentative valuations and shall be reported to Congress at the beginning of each regular session.

In formation To enable the Commission to make such changes and required of car-
rlers. every common carrier subject to the provisions of this Act shall make such reports and furnish such information as the Commission may require.

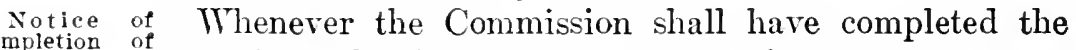
completion of
tentative ralu-tentative valuation of the property of any common car-
ation. rier, as herein directed, and before such valuation shall become final, the Commission shall give notice by registered letter to the said carrier, the Attorney General of the United States, the governor of any State in which the property so ralued is located, and to such additional parties as the Commission may prescribe, stating the valuation placed upon the several classes of property of said carrier, and shall allow thirty days in which to file a Finality if no protest of the same with the Commission. If no protest protest filed. is filed within thirty days, said valuation shall become final as of the date thereof.

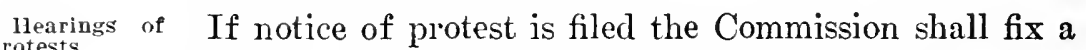
protests. time for hearing the same, and shall proceed as promptly as may be to hear and consider any matter relative and material thereto which may be presented in support of changes. any such protest so filed as aforesaid. If after hearing any protest of such tentative valuation under the provisions of this Act the Commission shall be of the opinion that its raluation should not become final, it shall make such changes as may be necessary, and shall issue an order making such corrected tentative valuation final as of the Effect of final clate thereof. All final valuations by the Commission and valuation and the classification thereof shall be published and shall be
classification. 
prima facie evidence of the value of the property in all proceedings under the Act to regulate commerce as of the date of the fixing thereof, and in all judicial proceedings for the enforcement of the Act approved February fourth, eighteen hundred and eighty-seren, commonly known as "the Act to regulate commerce," and the rarious Acts amendatory thereof, and in all judicial proceedings brought to enjoin, set aside, annul, or suspend, in whole or in part, any order of the Interstate Commerce Commission.

If upon the trial of any action involving a final value Effect of erl. fixed by the Commission, evidence shall be introduced regarding such value which is found by the court to be different from that offered upon the hearing before the Commission, or additional thereto and substantially affecting said ralue, the court, before proceeding to render ${ }_{\text {to }}^{\text {Transmission }}$ Commission. judgment shall transmit a copy of such eridence to the Commission, and shall stay further proceedings in said action for such time as the court shall determine from the date of such transmission. Upon the receipt of such commission of evidence the Commission shall consider the same and may fix a final ralue different from the one fixed in the first instance, and may alter, modify, amend or rescind any order which it has made inrolring said final value, and shall report its action thereon to said court within the time fixed by the court. If the Commission shall alter, Mof order. modify, or amend its order, such altered, modified, or amended order shall take the place of the original order complained of and judgment shall be rendered thereon as though made by the Commission in the first instance. If the original order shall not be rescinded or changed Judgment on by the Commission, judgment shall be rendered upon such original order.

The provisions of this section shall apply to receivers Applicable to of carriers and operating trustees. In case of failure or refusal on the part of any carrier, receiver, or trustee to comply with all the requirements of this section and in the manner prescribed by the Commission such carrier, receiver, or trustee shall forfeit to the United States the Penalty. sum of fire hundred dollars for each such offense and for each and every day of the continuance of such offense, such forfeitures to be recoverable in the same manner as other forfeitures provided for in section sixteen of the Act to regulate commerce.

That the district courts of the United States shall have of Jurisdiction jurisdiction, upon the application of the Attorney General courts to comof the United States at the request of the Commission, 
alleging a failure to comply with or a violation of any of the provisions of this section by any common carrier, to issue a writ or writs of mandamus commanding such common carrier to comply with the provisions of this section.

Supplemental Act of August 1,1914 .

It shall be the duty of every common carrier by railroad whose property is being valued under the Act of March first, nineteen hundred and thirteen, to transport the engineers, field parties, and other employees of the United States who are actually engaged in making surveys and other examination of the physical property of said carrier necessary to execute said Act from point to point on said railroad as may be reasonably required by them in the actual discharge of their duties; and, also, to move from point to point and store at such points as may be reasonably required the cars of the United States which are being used to house and maintain said employees; and, also, to carry the supplies necessary to maintain said employees and the other property of the United States actually used on said railroad in said work of valuation. The service above required shall be regarded as a special service and shall be rendered under such forms and regulations and for such reasonable compensation as may be prescribed by the Interstate Commerce Commission and as will insure an accurate record and account of the service rendered by the railroad, and such evidence of transportation, bills of lading, and so forth, shall be furnished to the Commission as may from time to time be required by the Commission.

Commission SEc. 20. (As amended June 29, 1906, February 25, 1909, annual reports and June 18,1910.) That the Commission is hereby aumethod of mak- thorized to require annual reports from all common car-
ing same. riers subject to the provisions of this Act, and from the owners of all railroads engaged in interstate commerce as defined in this Act, to prescribe the manner in which such reports shall be made, and to require from such carriers specific answers to all questions upon which the What reports Commission may need information. Such annual reports contain.

shall show in detail the amount of capital stock issued, the amounts paid therefor, and the manner of payment for the same; the dividends paid, the surplus fund, if any, and the number of stockholders; the funded and floating debts and the interest paid thereon; the cost and value of the carrier's property, franchises, and equipments; the number of employees and the salaries paid each class; the amounts expended for improvements each year, how expended, and the character of such improve- 
ments; the earnings and receipts from each branch of business and from all sources; the operating and other expenses; the balances of profit and loss; and a complete exhibit of the financial operations of the carrier each year, including an annual balance sheet. Such reports shall also contain such information in relation to rates or regulations concerning fares or freights, or agreements, arrangements, or contracts affecting the same as the Commission may require; and the Commission may, in its discretion, for the purpose of enabling it the better to carry out the purposes of this Act, prescribe a period of time within which all common carriers subject to the provisions of this Act shall have, as near as may be, a uniform system of accounts, and the manner in which such accounts shall be kept.

Said detailed reports shall contain all the required statistics for the period of twelve months ending on the with to befiled thirtieth day of June in each year, or on the thirty-first tember ${ }_{30}{ }_{30}$ of day of December in each year if the Commission by order substitute that period for the year ending June thirtieth, and shall be made out under oath and filed with the Commission at its office in Washington within three months after the close of the year for which the report is made, unless additional time be granted in any case by the commission Commission; and if any carrier, person, or corporation ditional time. subject to the provisions of this Act shall fail to make and file said annual reports within the time above specified, or within the time extended by the Commission, for making and filing the same, or shall fail to make specific answer to any question authorized by the provisions of this section within thirty days from the time it is lawfully required so to do, such party shall forfeit to the United States the sum of one hundred dollars for each and every day it shall continue to be in default with respect thereto. The Commission shall also have authority by general or Monthly or $\begin{gathered}\text { or } \\ \text { re- }\end{gathered}$ special orders to require said carriers, or any of them, to ports. file monthly reports of earnings and expenses, and to file periodical or special, or both periodical and special, reports concerning any matters about which the Commission is authorized or required by this or any other law to inquire or to keep itself informed or which it is required to enforce; and such periodical or special reports shall be under oath whenever the Commission so requires; and if any such carrier shall fail to make and file any such periodical or special report within the time fixed by the Commission, it shall be subject to the forfeitures last above provided. 
Recovery of forfeitures.

Oath to anhow taken.

Commission may prescribe forms of accounts, records,

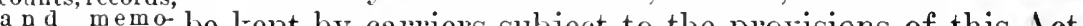

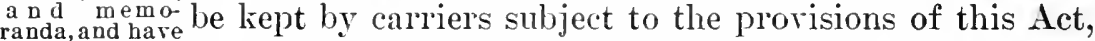
access thereto. including the accounts, records, and memoranda of the morement of traffic as well as the receipts and expenditures of moneys. The Commission shall at all times have access to all accounts, records, and memoranda kept by C a r rier to carriers subject to this Act, and it shall be unlawful for keep no other accounts than such carriers to keep any other accounts, records, or memthose pre- $\mathrm{r}$. mission.

commission who shall have authority under the order of the Commis$\mathrm{m}$ special exam. sion to inspect and examine any and all accounts, records, iners to in- and memoranda kept by such carriers. This provision and records.

$P$ un ishment of carrier by forfeiture fo $\mathrm{l}$ failure to keep accounts or records as prescribed bs Commission or to tion thereof.

shall apply to receivers of carriers and operating trustees.

In case of failure or refusal on the part of any such carrier, receiver, or trustee to keep such accounts, records, and memoranda on the books and in the manner prescribed by the Commission, or to submit such accounts, records, and memoranda as are kept to the inspection of the Commission or any of its authorized agents or examiners, such carrier, receiver. or trustee shall forfeit to the United States the sum of five hundred dollars for each such offense and for each and every day of the continuance of such offense, such forfeitures to be recoverable in the same manner as other forfeitures provided for in this Act.

Punishment Any person who shall willfully make any false entry in of person for the accounts of any book of accounts or in any record or ords, or muti-memoranda kept by a carrier. or who shall willfully delation of accounts or rec-stroy, mutilate, alter, or by any other means or device $\underset{\text { keeping }}{o r d s}$ other falsify the record of any such account, record, or memoaccounts than randa, or who shall willfully neglect or fail to make full, those pre-randa, or who shall willfully neglect or fail to make full, or $j \mathrm{mprison}$-true, and correct entries in such accounts, records, or ment or botb.

memoranda of all facts and transactions appertaining to the carrier's business, or shall keep any other accounts, records, or memoranda than those prescribed or approved by the Commission, shall be deemed guilty of a misdemeanor, and shall be subject, upon conriction in any court of the United States of competent jurisdiction, to a fine of not less than one thousand dollars nor more than five thousand dollars or imprisonment for a term not less than 
one year nor more than three years, or both such fine and imprisonment: Provided, That the Commission may in its Amendment liscretion issue orders specifying such operating, account- 1909. ing, or financial papers, records, books, blanks, tickets, may permit destubs, or documents of carriers which may, after a reason- records.

able time, be destroyed, and prescribing the length of time such books, papers, or documents shall be preserved.

Any examiner who divulges any fact or information of $\begin{gathered}P \text { unishment } \\ \text { special ex- }\end{gathered}$ which may come to his knowledge during the course of aminer who disuch examination, except in so far as he may be directed tion without by the Commission or by a court or judge thereof, shall or imprisonbe subject, upon conviction in any court of the United States of competent jurisdiction, to a fine of not more than fire thousand dollars or imprisonment for a term not exceeding two years, or both.

That the circuit and district courts of the United States shall have jurisdiction, upon the application of the Attor- sue mandamus to compel comney General of the United States at the request of the pliauce $w i t$ i Commission, alleging a failure to comply with or a viola- Act. tion of any of the provisions of said Act to regulate commerce or of any Act supplementary thereto or amendatory thereof by any common carrier, to issue a writ or writs of mandamus commanding such common carrier to comply with the provisions of said Acts, or any of them.

And to carry out and give effect to the provisions of Commission may e mploy said Acts, or any of them, the Commission is hereby aul- special examthorized to employ special agents or examiners who shall ceive evidence. have power to administer oaths, examine witnesses, and receive evidence.

That any common carrier, railroad, or transportation Initial carcompany receiving property for transportation from a loss or damage point in one State to a point in another State shall issue a shipments. receipt or bill of lading therefor and shall be liable to the lawful holder thereof for any loss, damage, or injury to such property caused by it or by any common carrier, railroad, or transportation company to which such property may be delivered or over whose line or lines such property may pass, and no contract, receipt, rule, or regulation shall exempt such common carrier, railroad, or transportation company from the liability hereby imposed: Provided, That nothing in this section shall de- Remedies unprive any holder of such receipt or bill of lading of any lawnot barred. remedy or right of action which he has under existing law.

That the common carrier, railroad, or transportation company issuing. such receipt or bill of lading shall be course up on entitled to recover from the common carrier, railroad, or sible for loss transportation company on whose line the loss, damage, or injury shall have been sustained the amount of such 
loss, damage, or injury as it may be required to pay to the owners of such property, as may be evidenced by any receipt, judgment, or transcript thereof.

A mendment of January 20 , 1914.

Annual reports of the Commission to
Congress.

rersons and property that may be carried duced rates.

No suit brought in any State court of competent jurisdiction against a railroad company, or other corporation, or person, engaged in and carrying on the business of a common carrier, to recover damages for delay, loss of, or injury to property received for transportation by such common carrier under section twenty of the Act to regulate commerce, approved February fourth, eighteen hundred and eighty-seren, as amended June twenty-ninth, nineteen hundred and six, April thirteenth, nineteen hun. dred and cight, February twenty-fifth, nineteen hundred and nine, and June eighteenth, nineteen hundred and ten, shall be removed to any com't of the United States where the matter in controversy does not exceed, exclusive of interest and costs, the sum or ralue of $\$ 3,000$.

Sec. 21. (As amended March 2, 1889.) That the Commission shall, on or before the first day of December in each year, make a report, which shall be transmitted to Congress, and copies of which shall be distributed as are the other reports transmitted to Congress. This report shall contain such information and data collected by the Commission as may be considered of value in the determination of questions connected with the regulation of commerce, together with such recommendations as to additional legislation relating thereto as the Commission may deem necessary; and the names and compensation of the persons employed by said Commission.

SEc. 22. (.ts amended March 2, 1889, and February 8 , 1895.) [See section 1, 5th par.] That nothing in this Act shall prevent the carriage, storage, or handling of property free or at reduced rates for the United States, State, or municipal governments, or for charitable purposes, or to or from fairs and expositions for exhibition thereat, or the free carriage of destitute and homeless persons transported by charitable societies, and the necessary Mileage, es-agents employed in such transportation, or the issuance cursion, or com. mutation pas-
senger tickets.

nothing in this Act shall be construed to prohibit any common carrier from giving reduced rates to ministers of religion, or to municipal gorernments for the transportation of indigent persons, or to inmates of the $\mathrm{Na}$ tional Homes or State Homes for Disabled Volunteer Soldiers, and of Soldiers' and Sailors' Orphan Homes, including those about to enter and those returning home after discharge, under arrangements with the boards of 
managers of said homes; nothing in this Act shall be con- l'asses and strued to prevent railroads from giving free carriage to tition to offitheir own officers and employees, or to prevent the princi- ployes of rail pal officers of any railroad company or companies from nies.

exchanging passes or tickets with other railroad companies for their oflicers and employees; and nothing in Provisions of this Act contained shall in any way abridge or alter the dition to tremeremedies now existing at common law or by statute, but common law. the provisions of this Act are in addition to such reme- tion not not the provisions of this Act are in addition to such reme- tion not act. dies: Provided, That no pending litigation shall in any way be affected by this Act: Provided further, That noth- $\mathrm{choint}$ in terin $\mathrm{g}$ in this Act shall prevent the issuance of joint inter- five - thousandchangeable five-thousand-mile tickets, with special privi- $\begin{aligned} & \text { Amount of free } \\ & \text { baggage. }\end{aligned}$

leges as to the amount of free baggage that may be carried under mileage tickets of one thousand or more miles. But before any common carrier, subject to the provisions of this Act, shall issue any such joint interchangeable mileage tickets with special privileges, as aforesaid, it shall file with the Interstate Commerce Commission copies of the joint tariffs of rates, fares, or charges on which such joint interchangeable mileage tickets are to be based, together with specifications of the amount of free baggage permitted to be carried under such tickets, in the same manner as common carriers are required to do with regard to other joint rates by section six of this Act; and all the provisions of said section six relating to joint rates, $\begin{gathered}\text { Rates to be } \\ \text { published, fiied, }\end{gathered}$ fares, and charges shall be observed by said common car- and observed. riers and enforced by the Interstate Commerce Commission as fully with regard to such joint interchangeable mileage tickets as with regard to other joint rates, fares, and charges referred to in said section six. It shall be unlawful for any common carrier that has issued or allthorized to be issued any such joint interchangeable mileage tickets to demand, collect, or receive from any person or persons a greater or less compensation for transportation of persons or baggage under such joint interchangeable mileage tickets than that required by the rate, fare, or charge specified in the copies of the joint tariff of rates, fares, or charges filed with the Commission in force at the time. The provisions of section ten of this Act shall apply to any violation of the requirements of this proviso.

SEc. 23. (Added March 2, 1889.) That the circuit and United States jourts to com district courts of the United States shall have jurisdiction mand $\mathrm{m}$ o veupon the relation of any person or persons, firm, or corpo- state traffic or , firm, or corpo- the furnishing ration, alleging such violation by a common carrier, of of other transporany of the provisions of the Act to which this is a supple- tation facili- 
ment and all Acts amendatory thereof, as prevents the relator from having interstate traffic moved by said common carrier at the same rates as are charged, or upon terms or conditions as farorable as those given by said common carrier for like traftic under similar conditions to any other shipper, to issue a writ or writs of mandamus against said common carrier. commanding such common carrier to move and transport the traffic, or to furnish cars or other facilities for transportation for the party applying for the writ: Provided, That if any question of fact as to the proper compensation to the common carrier for the service to be enforced by the writ is raised by the pleadings, the writ of peremptory mandamus may issue, notwithstanding such question of fact is undetermined, upon such terms as to security, payment of money into the court, or otherwise, as the court may think proper, pend$\mathrm{R}$ e medy is ing the determination of the question of fact: Provided,
cumulative.

That the remedy hereby given by writ of mandamus shall be cumulative, and shall not be held to exclude or interfere with other remedies provided by this Act or the Act to which it is a supplement.

to commission of SEc. 24. (Added June 29, 1906.) That the Interstate se ren mem- Commerce Commission is hereby enlarged so as to consist
bers i terms ; Commer. salaries.

of seven members with terms of seven years, and each shall receive ten thousand dollars compensation annually. Qualifications The qualifications of the Commissioners and the unanner
of Commission. The ers. of the payment of their salaries shall be as already provided by law. Such enlargement of the Commission shall be accomplished through appointment by the President, by and with the adrice and consent of the Senate, of two additional Interstate Commerce Commissioners, one for a term expiring December thirty-first, nineteen hundred and eleven, one for a term expiring December thirty-first, nineteen hundred and twelve. The terms of the present Commissioners, or of any successor appointed to fill a vacancy caused by the deatl or resignation of any of the present Commissioners, shall expire as heretofore provided by law. Their snccessors and the successors of the additional Commissioners herein provided for shall be appointed for the full terms of seven years, except that any person appointed to fill a vacancy shall be appointed only for the unexpired term of the Commissioner whom he shall succeed. Not more than four Commissioners shall be appointed from the same political party. 
(Additional provisions in Act of June 99,1906 .) (SEc Existing laws 9.) That all existing laws relating to the attendanof as to attend . witnesses and the production of evidence and the com-duction of pripelling of testimony under the Act to regulate commerce ble in proceedand all Acts amendatory thereof shall apply to any and $\begin{gathered}\text { ings under this } \\ \text { cct. }\end{gathered}$ all proceedings and hearings under this Act.

(SEC. 10.) That all laws and parts of laws in conflict conficting with the provisions of this Act are hereby repealed; but the amendments herein provided for shall not affect causes not to iffect now pending in courts of the United States, but such pending cauluses causes shall be prosecuted to a conclusion in the manner heretofore provided by law.

(SFC 11.) That this Act shall take effect and be in force when Act effrom and after its passage.

Joint resolution of June 30,1906, provides: "That the ine of takAct entitled 'An Act to amend an Act entitled "An Act to teuded 60 dars

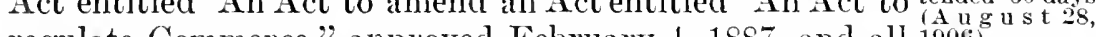
regulate Commerce," approved February 4, 18s7, and all 1906).

Acts amendatory thereof, and to enlarge the porrers of the Interstate Commerce Commission,' shall take effect and be in force sixty days after its approval by the President of the United States."

(Additional provisions in Act of June 18,1910.) (SEc. 6, par. 2.) It shall be the duty of every common carrier agents at in subject to the provisions of this Act, within sixty days for purposes after the taking effect of this Act, to designate in writing an agent in the city of Washington, District of Columbia, upon whom service of all notices and processes may be made for and on behalf of said common carrier in any proceeding or suit pending before the Interstate Commerce Commission or before said Commerce Court, and to file such designation in the office of the secretary of the Interstate Commerce Commission, which designation may from time to time be changed by like writing similarly filed; and thereupon service of all notices and processes may be made upon such common carrier by learing a Se r vice on such agents. copy thereof with such designated agent at his office or usual place of residence in the city of Washington, with like effect as if made personally upon such common carrier, and in default of such designation of such agent, service of any notice or other process in any proceeding before said Interstate Cominerce Commission or Commerce Court may be made by posting such notice or process in the office of the secretary of the Interstate Commerce Commission.

(SEC. 15.) That nothing in this Act contained shall undo or impair any proceedings heretofore taken by or before the Interstate Commerce Commission or any of the acts of said Commission; and in any cases, proceedings,

$66170^{\circ}-14-4$ 
or matters now pending before it, the Commission may exercise any of the powers hereby conferred upon it, as would be proper in cases, proceedings, or matters hereafter initiated and nothing in this Act contained shall Existing lia- operate to release or affect any obligation, liability, pen-
bilities. alty, or forfeiture heretofore existing against or incurred by any person, corporation, or association.

When Act ef-
(SEc.18.) That this Act shall take effect and be in force fective (August $17,1910)$.

from and after the expiration of sixty days after its passage, except as to sections twelve and sixteen, which sections shall take effect and be in force immediately.

Public, No. 41, approved February 4, 1887, as amended by Public, No. 125, approved March 2, 1889; Public, No. 72, approved February 10, 1891; Public, No. 38, approved February 8, 1895; Public, No. 337, approved June 29, 1906; Public Res., No. 47, approved June 30, 1906; Public, No. 95, approved April 13, 1908; Public, No. 262, approved February 25, 1909; Public, No. 218, approved June 18, 1910; Public, No. 337, approved August 24, 1912 ; Public, No. 400, approved March 1, 1913; Public, No. 48, approved January 20,-1914; and Public, No. 161, approved August 1, 1914.

\section{DISTRICT COURT JURISDICTION ACT.}

AN AC'T Making appropriations to supply urgent deficiencies in appropriations for the fiscal year nineteen bundred and thirteen, and for other purposes.

* * * * * *

The Commerce Court, created and established by the Act entitled "An Act to create a Commerce Court and to amend the Act entitled 'An Act to regulate commerce,' approved February fourth, eighteen hundred and eighty-seven, as heretofore amended, and for other purposes,", approved Commerce June eighteenth, nineteen hundred and ten, is abolished Co ou $\mathrm{r}$ t aboi-
ished. and thirteen, and the jurisdiction rested in said Commerce Court by said Act is transferred to and rested in the several clistrict courts of the United States, and all Acts or parts of Acts in so far as they relate to the establishment of the Commerce Court are repealed. Nothing herein contained shall be deemed to affect the tenure of any of the judges now acting as circuit judges by appointment under the terms of said Act, but such judges shall continue to act under assignment, as in the said Act provided, as

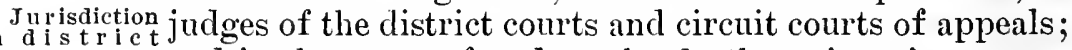
courts. and in the event of and on the death, resignation, or re-

Tenure of of- moval from office of any of such judges, his office is hereby fice.

abolished and no successor to him shall be appointed. 
The venue of any suit hereafter brought to enforce, $\begin{gathered}\mathrm{v} \text { e n u e of } \\ \text { suits on orders }\end{gathered}$ suspend, or set aside, in whole or in part, any order of of Interstate the Interstate Commerce Commission shall be in the judi-mission. Comcial district wherein is the residence of the party or any of the parties upon whose petition the order was made, except that where the order does not relate to transportation or is not made upon the petition of any party the venue shall be in the district where the matter complained of in the petition before the Commission arises, and except that where the order does not relate either to transportation or to a matter so complained of before the Commission the matter covered by the order shall be deemed to arise in the district where one of the petitioners in court has either its principal office or its principal operat- Principal ofing office. In case such transportation relates to a through shipment the term "destination" shall be construed as meaning final destination of such shipment.

The procedure in the district courts in respect to cases of which jurisdiction is conferred upon them by this Act shall be the same as that heretofore prevailing in the Commerce Court. The orders, writs, and processes of the district courts may in these cases run, be served, and be returnable anywhere in the United States; and the right of appeal from the district courts in such cases shall be the same as the right of appeal heretofore prevailing under existing law from the Commerce Court. No interlocutory injunction suspending or restraining Interlocutory the enforcement, operation, or execution of, or setting aside, in whole or in part, any order made or entered by the Interstate Commerce Commission shall be issued or granted by any district court of the United States, or by any judge thereof, or by any circuit judge acting as district judge, unless the application for the same shall be presented to a circuit or district judge, and shall be heard and determined by three judges, of whom at least one shall be a circuit judge, and unless a majority of said three judges shall concur in granting such application. When such application as aforesaid is presented to a judge, he shall immediately call to his assistance to hear and determine the application two other judges. Said application shall not be heard or determined before at least five days' notice of the hearing has been given to the Interstate Commerce Commission, to the Attorney General of the United States, and to such other persons

Notice. Procedure in
district courts. 
as may be clefendants in the suit: Provided, That in cases where irreparable damage would otherwise ensue to the petitioner, a majority of said three judges concurring, may, on hearing, after not less than three days' notice to the Interstate Commerce Commission and the Attorney Temporary General, allow a temporary stay or suspension, in whole
stay. or in part, of the operation of the order of the Interstate Commerce Commission for not more than sixty days from the date of the order of said judges pending the application for the order or injunction, in which case the said order shall contain a specific finding, based upon evidence submitted to the judges making the order and identified

Irreparable by reference thereto, that such irreparable damage would result to the petitioner and specifying the nature of the damage. The said judges may, at the time of hearing such application, upon a like finding, continue the temporary stay or suspension in whole or in part until Hearing. decision upon the application. The hearing upon such application for an interlocutory injunction shall be given precedence and shall be in every way expedited and be assigned for a hearing at the earliest practicable day after the expiration of the notice hereinbefore provided for. Appeal. An appeal may be taken direct to the Supreme Court of the United States from the order granting or denying, after notice and hearing, an interlocutory injunction, in such case if such appeal be taken within thirty days after the order, in respect to which complaint is made, is granted or refused; and upon the final hearing of any suit brought to suspend or set aside, in whole or in part, any order of said Commission the same requirement as to judges and the same procedure as to expedition and apFinal judg- peal shall apply. A final judgment or decree of the dis-
ment. trict court may be reviewed by the Supreme Court of the United States if appeal to the Supreme Court be taken by an aggrieved party within sixty days after the entry of such final judgment or decree, and such appeals may be taken in like manner as appeals are taken under existing law in equity cases. And in such case the notice required shall be served upon the defendants in the case Cases pend- and upon the attorney general of the State. All cases
ing. pending in the Commerce Court at the date of the passage of this Act shall be deemed pending in and be transferred forthwith to said district courts except cases which may previously have been submitted to that court for 
final decree and the latter to be transferred to the district. courts if not decided by the Commerce Court before December first, nineteen hundred and thirteen, and all cases wherein injunctions or other orders or decrees, mandatory or otherwise, have been directed ol entered prior to the abolition of the said court shall be transferred forthwith to said district courts, which shall have jurisdiction to proceed therewith and to enforce said injunctions, orders, or decrees. Each of said cases and all the records, ${ }_{\text {to }}^{\text {Transference }}$ district papers, and proceedings shall be transferred to the district courts. court wherein it might have been filed at the time it was filed in the Commerce Court if this Act had then been in effect; and if it might have been filed in any one of two or more district courts it shall be transferred to that one of said-district courts which may be designated by the petitioner or petitioners in said case, or, upon failure of said petitioners to act in the premises within thirty days after the passage of this Act, to such one of said district courts as may be designated by the judges of the Commerce Court. The judges of the Commerce Court shall have authority, and are hereby directed, to make any and all orders and to take any other action necessary to transfer as aforesaid the cases and all the records, papers, and proceedings then pending in the Commerce Court to said district courts. All administrative books, dockets, files, and all papers of the Commerce Court not transferred as part of the record of any particular case shall be lodged in the Department of Justice. All furmiture, carpets, and other property of the Commerce Court is turned over to the Department of Justice and the Attorney General is authorized to supply. such portion thereof as in his judgment may be proper and necessary to the United States Board of Mediation and Conciliation.

Any case hereafter remanded from the Supreme Court $\begin{gathered}\text { S u p p r e me } \\ \text { to }\end{gathered}$ which, but for the passage of this Act, would have been mand. remanded to the Commerce Court, shall be remanded to a district court, designated by the Supreme Court, wherein it might have been instituted at the time it was instituted in the Commerce Court if this Act had then been in effect, and thereafter such district court shall take all necessary and proper proceedings in such case in accordance with law and such mandate, order, or decree therein as may be made by said Supreme Court. 
Repeal.

All laws or parts of laws inconsistent with the foregoing provisions relating to the Commerce Court, are repealed.

*

$*$

*

Public, No. 32. approved October 22, 1913.

\section{COMPULSORY 'TESTIMONY ACT,}

AN ACT In relation to testimony before the Interstate Commerce Commission, and in cases or proceedings under or connected with an Act entitled "An Act to regulate commerce," approved February fourth, eighteen hundred and eighty-seren, and amendments thereto.

Be it enacted by the Senate and House of Representawe e person to sembled, That no person shall be excused from attending tives of the United States of America in Congress asfrom fear of in and testifying or from producing books, papers, tariffs, criminatiou. contracts, agreements and documents before the Interstate Commerce Commission, or in obedience to the subpœna of the Commission, whether such subpœna be signed or issued by one or more Commissioners, or in any cause or proceeding, criminal or otherwise, based upon or growing out of any alleged violation of the Act of Congress, entitled "An Act to regulate commerce," approved February fourth, eighteen hundred and eightyseven, or of any amendment thereof on the ground or for the reason that the testimony or evidence, documentary or otherwise, required of him, may tend to criminate him or Immunity. subject him to a penalty or forfeiture. But no person shall be prosecuted or subjected to any penalty or forfeiture for or on account of any transaction, matter or thing, concerning which he may testify, or produce evidence, documentary or otherwise, before said Commission, or in obedience to its subpœena, or the subpœna of either of them, or in any such case or proceeding: ProPerjury may vided, That no person so testifying shall be exempt from
punished. prosecution and punishment for perjury committed in so testifying.

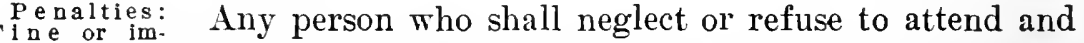
prisonment, or testify, or to answer any lawful inquiry, or to produce
both. books, papers, tariffs, contracts, agreements and documents, if in his power to do so, in obedience to the subpœna or lawful requirement of the Commission shall be guilty of an offense and upon conviction thereof by a 
court of competent jurisdiction shall be punished by fine not less than one hundred dollar's nor more than five thousand dollars, or by imprisonment for not more than one year or by both such fine and imprisonment.

Public, No. 54, approved February 11, 1893

\section{IMMUNITY OF WITNESSES ACT.}

AN ACT Defining the right of immunity of witnesses under the Act entitled "An Act in relation to testimony before the Interstate Commerce Commission," and so forth, approved February eleventh, eighteen hundred and ninety-three, and an Act entitled "An Act to establish the Department of Commerce and Labor," approred February fourteenth, nineteen hundred and three, and an Act entitled "An Act to further regulate commerce with foreign nations and among the States," approved February nineteenth, nineteen hundred and three, and an Act entitled "An Act making appropriations for the legislative, executive, and judicial expenses of the Government for the fiscal year ending June thirtieth, nineteen hundred and four, and for other purposes," approved February twenty-fifth, nineteen hundred and three.

Be it enacted by the Senatc and House of Representatives of the United States of America in Congress assembled, That under the immunity provisions in the Act entitled "An Act in relation to testimony before the Interstate Commerce Commission," and so forth, approved February eleventh, eighteen hundred and ninety-three, in section six of the Act entitled "An Act to establish the Department of Commerce and Labor," approved February fourteenth, nineteen hundred and three, and in the Act entitled "An Act to further" regulate commerce with foreign nations and among the States," approved February nineteenth, nineteen hundred and three, and in the Act entitled "An Act making appropriations for the legislative, executive, and judicial expenses of the Government for the fiscal year ending June thirtieth, nineteen hundred and four, and for other purposes," approved February twenty-fifth, nineteen hundred and three, im- Immunity exmunity shall extend only to a natural person who, in tends ontural to torsons obedience to a subpona, gives testimony under oath or mony und uestiproduces evidence, documentary or otherwise, under oath. under o a n d Public, No. 389, approved June 30, 1906. 


\section{ELKINS ACT.}

AN ACT To further regulate commerce with foreign nations and among the states.

Be it enacted by the Senate and House of Representatives of the United States of America in Congress assemCorporation bled, SEc. 1. (.1s amended June 29, 1906.) That any cer or agent thing done or omitted to be done by a corporation comliable. mon carrier, subject to the Act to regulate commerce and the Acts amendatory thereof, which, if done or omitted to be done by any director or officer thereof, or any receiver, trustee, lessee, agent, or person acting for or employed by such corporation, would constitute a misdemeanor under said Acts or under this Act, shall also be held to be a misdemeanor committed by such corporation, Penalty. and upon conviction thereof it shall be subject to like penalties as are prescribed in said Acts or by this Act with reference to such persons, except as such penalties are Failure of herein changed. The willful failure upon the part of any carrier to publish rates or carrier subject to said Acts to file and publish the tariffs
observe tariffs a misdemeanor. or rates and charges as required by said Acts, or strictly to observe such tariffs until changed according to law, shall be a misclemeanor, and upon conviction thereof the Penalty, fine. corporation offending shall be subject to a fine of not less than one thousand dollars nor more than twenty thousand Misdemeanor dollar's for each offense; and it shall be unlawful for any to ofrer, grant, person, persons, or corporation to offer, grant, or give, cept, or receive
any relate, con- or to solicit, accept, or receive any rebate, concession, or cession or dis- discrimination in respect to the transportation of any
crimination. property in interstate or foreign commerce by any common carrier subject to said Act to regulate commerce and the Acts amendatory thereof whereby any such property shall by any device whatever be transported at a less rate than that named in the tariffs published and filed by such carrier, as is required by said Act to regulate commerce and the Acts amendatory thereof, or whereby any other advantage is given or discrimination is practiced. Every person or corporation, whether carrier or shipper, who shall, knowingly, offer, grant, or give, or solicit, accept, or receive any such rebates, concession, or discrimination shall be deemed guilty of a misdemeanor, and on conPealits, fine viction thereof shall be punished by a fine of not less
immrisonor
ment, or both. than one thousand dollars nor more than twenty thousand dollars: Provided, That any person, or any officer or di- 
rector of any corporation subject to the provisions of this Act, or the Act to regulate commerce and the Acts amendatory thereof, or any receiver, trustee, lessee, agent, or person acting for or employed by any such corporation, who shall be convicted as aforesaid, shall, in addition to the fine herein provided for, be liable to imprisonment in the penitentiary for a term of not exceeding two years, or both such fine and imprisonment, in the

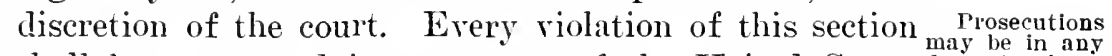
shall be prosecuted in any court of the United States $i$ is t $r$ in $i c t$ having jurisdiction of crimes within the district in which transportation such riolation was committed, or through which the transportation may have been conducted; and whenever the offense is begun in one jurisdiction and completed in another it may be dealt with, inquired of, tried, determined, and punished in either jurisdiction in the same manner as if the offense had been actually and wholly committed therein.

In construing and enforcing the provisions of this $\begin{gathered}\text { Principalsare } \\ \text { liable for acts }\end{gathered}$ section, the act, omission, or failure of any officer, agent, of agents. or other person acting for or employed by any common carrier, or shipper, acting within the scope of his employment, shall in every case be also deemed to be the act, omission, or failure of such carrier or shipper as well as that of the person. Whenever any carrier files with the Interstate Commerticipated in the Interstate Commerce Commission or publishes a par- by carrier shall, ticular rate under the provisions of the Act to regulateca ar $\mathrm{rer}$. be commerce or Acts amendatory thereof, or participates in any rates so filed or published, that rate as against such carrier, its officers or agents, in any prosecution begun under this Act shall be conclusively deemed to be the legal rate, and any departure from such rate, or any offer to depart therefrom, shall be deemed to be an offense under this section of this Act.

Any person, corporation, or company who shall deliver property for interstate transportation to any common carrier, subject to the provisions of this Act, or for whom as consignor or consignee, any such carrier shall transport property from one State, Territory, or the District of Columbia to any other State, Territory, or the District of Columbia, or foreign country, who shall knowingly by employee, agent, officer, or otherwise, directly or indirectly, by or through any means or device whatsoever, receive or accept from such common carrier any sum of 
money or any other valuable consideration as a rebate or offset against the regular charges for transportation of such property, as fixed by the schedules of rates provided Forfeiturefor in this Act, shall in addition to any penalty proforced against vided by this Act forfeit to the United States a sum of

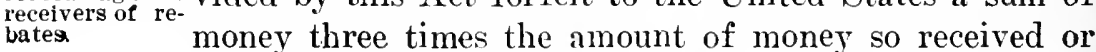
accepted and three times the value of any other consideration so received or accepted, to be ascertained by the trial court; and the Attorney General of the United States is authorized and directed, whenever he has reasonable grounds to believe that any such person, corporation, or company has knowingly received or accepted from any such common carrier any sum of money or other valuable consideration as a rebate or offset as aforesaid, to institute in any court of the United States of competent jurisdiction a civil action to collect the said sum or sums so forfeited as aforesaid; and in the trial of said action all such rebates or other considerations so received or accepted for a period of six years prior to the commencement of the action, may be inchuded therein, and the amount recovered shall be three times the total amount of money, or three times the total value of such consideration, so received or accepted, or both, as the case may be.

Persons inter- Sec. 2. That in any proceeding for the enforcement of
ested in matin $r$ in involved the provisions of the statutes relating to interstate comInterstate merce, whether such proceedings be instituted before the com merce merce, whether such proceedings be instituted before the commission or Interstate Commerce Commission or be begun originally may be made in any circuit court of the United States, it shall be law parties and shaii be sub- ful to include as parties, in addition to the carrier, all ject to orders
or decrees.

persons interested in or affected by the rate, regulation, or practice under consideration, and inquiries, investigations, orders, and decrees may be made with reference to and against such additional parties in the same manner, to the same extent, and subject to the same provisions as are or shall be authorized by law with respect to carriers.

courtmay SEc. 3. That whenever the Interstate Commerce Comrestrain departures from pub-mission shall have reasonable ground for belief that any a $y$ discrimi-common carrier is engaged in the carriage of passengers nation prohib- or freight traffic between given points at less than the published rates on file, or is committing any discriminations forbidden by law, a petition may be presented alleging such facts to the circuit court of the United States sitting in equity having jurisdiction; and when the act 
complained of is alleged to have been committed or as being committed in part in more than one judicial district or State, it may be dealt with, inquired of, tried, and determined in either such judicial district or State, whereupon it shall be the duty of the court summarily to inquire into the circumstances, upon such notice and in such manner as the court shall direct and without the formal pleadings and proceedings applicable to ordinary suits in equity, and to make such other persons or corporations parties thereto as the court may deem necessary, and upon being satisfied of the truth of the allegations of said petition said court shall enforce an observance of the published tariffs or direct and require a discontinuance of such discrimination by proper orders, writs, and process, which said orders, writs, and process may be enforceable as well against the parties interested in the traffic as against the carrier, subject to the right of appeal as now provided by law. It shall be the duty of the several district attomeys of the United States, whenever the Attorney General shall direct, either of his own motion or upon the request of the Interstate Commerce Commission, to institute and prosecute such proceedings, and the proceedings provided for by this Act shall not preclude the bringing of suit for the recovery of damages by any party injured, or any other action provided by said Act approved February fourth, eighteen hundred and eighty-seven, entitled "An Act to regulate commerce" and the Acts amendatory thereof. An in proceedings under this Act and the Acts to regulate commerce the said ance and testicourts shall have the porrer to compel the attendance of messes of wit prowitnesses, both upon the part of the carrier and the ship- books and paper, who shall be required to answer on all subjects relating directly or indirectly to the matter in controversy, and to compel the production of all books and papers, both of the carrier and the shipper, which relate directly or indirectly to such transaction; the claim that such testimony or evidence may tend to criminate the person giving such evidence shall not excuse such person from testifying or such corporation producing its books and papers, but no person shall be prosecuted or subjected to any penalty or forfeiture for or on account of any transaction, matter, or thing coneerning which he may testify or produce evi-

Immunity. 
Expediting dence documentary or otherwise in such proceeding: Pro-
ct of Feb. 11 , Act of Feb. 11,
1903 , to apply a
in cases cuted under di- expedite the hearing and determination of suits in equity rection of At- torencel pending or hereafter brought under the Act of July
in name of $1 \mathrm{n}$ -

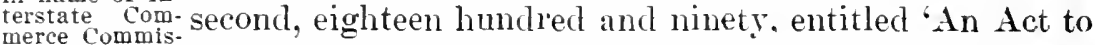
mion. Commis- protect trade and commerce against unlawful restraints and monopolies,' 'An Act to regulate commerce,' approved February fourth. eighteen hundred and eighty-seren, or any other acts haring a like purpose that may be hereafter enacted. approred February eleventh, nineteen hundred and three," shall apply to any case prosecuted under the direction of the Attorney General in the name of the Interstate Commerce Commission.

conticting SEC. 4. That all Acts and parts of Acts in conflict with lanio repealed. the provisions of this Act are hereby repealed, but such repeal shall not affect causes now pending nor rights which have already acerued, but such causes shall be prosecuted to a conclusion and such rights enforced in a manner heretofore provided by law and as modified by the provisions of this Act.

SEC. 5. That this Act shall take effect from its passage. Public. No. 103, approved February 19, 1903.

(See additional provisions in act of June 29, 1906, p. 46, herein.)

\section{EXPEDITIYG ACT,}

AN ACT To expedite the hearing and determination of suits in equity yending or hereafter brought under the act of July second, eighteen hundred and ninety, entitled "An Act to protect trade and commerce against unlawful restraints and monopolies," "An Act to regulate commerce," approved February fourth, eighteen hundred and eighty-seren. or any other Acts liaving a like purpose that may be hereafter enacted.

Be it enacted by the Senate and House of Representatives of the United States of America in Congress assem7,led, Sec. 1. (As amended June 25, 1910.) That in any snit in equity pending or hereafter brought in any circuit court of the United States under the Act entitled "An Act to protect trade and commerce against unlawful restraints and monopolies," approved July second, eighteen hundred and ninety, "An Act to regulate commerce." approved February fourth, eighteen hundred 
and eighty-seren, or any other Acts having a like purpose that hereafter may be enacted, wherein the United States is complainant, the Attorney General may file with A t t o r a e y the clerk of such court a certificate that, in his opinion, file certificate. the case is of general public importance, a copy of which shall be immediately furnished by such clerk to each of the circuit judges of the circuit in which the case is pending. Thereupon such case shall be given precedence over others and in every way expedited, and be assigned for hearing at the earliest practicable day, before not less for earing bethan three of the circuit judges of said court, if there be Judges. three or more; and if there be not more than two circuit judges, then before them and such district judge as they may select; or, in case the full court shall not at any time be made up by reason of the necessary absence or disqualification of one or more of the said circuit judges, the justice of the Supreme Court assigned to that circuit or the other circuit judge or judges may designate a district judge or judges within the circuit who shall be competent to sit in said court at the hearing of said suit. In the event the judges sitting in such case shall be equally divided in opinion as to the decision or disposition of said cause, or in the event that a majority of said judges shall be unable to agree upon the judgment, order, or decree finally disposing of said case in said court which should be entered in said cause, then they shall immediately certify that fact to the Chief Justice chief Justice of the United States, who shall at once designate and circuit judge appoint some circuit judge to sit with said judges and to in $\mathrm{c}$ a s a of assist in determining said cause. Such order of the Chief Justice shall be immediately transmitted to the clerk of the circuit court in which said cause is pending, and shall be entered upon the minutes of said court. Thereupon said cause shall at once be set down for reargument and the parties thereto notified in writing by the clerk of said court of the action of the court and the date fixed for the reargument thereof. The provisions of this section shall apply to all causes and proceedings in all courts now pending, or which may hereafter be brought. SEc. 2. That in every suit in equity pending or here- Appeal to Suafter brought in any circuit court of the United States under any of said Acts, wherein the United States is complainant, including cases submitted but not yet decided, an appeal from the final decree of the circuit court will lie

Reargument. 
only to the Supreme Court and must be taken within sixty Esception. day from the entry thereof: Provided. That in any case where an appeal may have been talien from the final decree of a ciretuit court to the circuit court of appeals before this Act takes etfect. the case shall proceed to a final decree therein. and an appeal may be taken from such decree to the Supreme Court in the manner now provided by law. Public. No. S. approved February 11. 1903; Public, 5o.310. approvet ofune 2.5. 1210.

\section{CLAETOY AVTITREST ACT.}

AX ACT To supplenent existing lats against tnlawtul restraints and monopolies. and tor other purposes.

$*$

* * *

*

*

Sis asurimi면i口 2 in prices.

SEC. 2. That it shall be unlawtul for any person envaged in commerce. in the course of such commerce, either directly or indirectly to discriminate in price between different purchasers of commodities. which commodities are sold for use. consumption. or resale within the United States or any Territory thereof or the District of Columbia or any insular possession or other place under the jurisdiction of the Tinited States. Where the effect of stch discrimination may be to substantially lessen competition or tend to create a monopoly in any line of comEsceptions. merce: Protided. That nothing herein contained shall prevent discrimination in price between purchasers of commodities on account of differences in the grade, quality. or quantity of the commodity sold. or that makes only due allowance for difference in the cost of selling or transportation. or discrimination in price in the same or different communities made in good faith to meet competition: And provided further. That nothing herein contained shall prevent persons engaged in selling goods. wares. or merchandise in commerce from selecting their own customers in bona fide transactions and not in restraint of trade.

Talawit s. SEC. to is prices da to crealy.
aopoly.

gaged in commerce. in the course of such commerce, to lease or make a sale or contract for sale of goods, wares, merchandise. machinery. supplies or other commodities, whether patented or unpatented. for use. consumption or resale within the Cnited States or any Territory thereof 
or the District of Columbia or ant insular possession or other place under the jurisdiction of the United States. or fix a price charged therefor. or discount from. or rebate upon. such price. on the condition. agreement or understanding that the lessee or purchaser thereof shall not use or deal in the groods. Wares. merchandise. machinery, supplies or other commodities of a competitor or competitors of the lessor or seller. where the effect of such lease. sale. or contract for sale or such condition. agreement or understanding may be to substantially lessen competition or tend to create a monopoly in any line of commerce.

SEC. T. That no corporation engaged in commerce shall acquire. directly or indirectly. the whole or ant part of the stock or other share capital of another corporation engaged also in commerce. Where the efiect of such acquisition mar be to substantialls lessen competition between the corporation whose stack is so acquired and the corporation making the acquisition. or to restrain such commerce in ans section or community. or tend to create a monopoly of any line of commerce.

To corporation shall acquire. directls or indirectly. the ros whole or any part of the stock or other share capital of two or more corporations engaged in commerce where the effect of such acquisition. or the use of such stock br the roting or granting of prosies or otherwise. mar be to substantially lessen competition betmeen such corporations. or ant of them. Whose stock or other share capital is so acquired. or to restrain such commerce in ant section or community. or tend to create a monopoly of any line of commerce.

This section shall not apply to corporations purchasing Esceptions. such stock solely for inrestment and not using the same br roting or otherwise to bring about. or in atttempting to bring about. the substantial lessening of competition. Nor shall anrthing contained in this section prerent a corporation engaged in commerce from causing the formation of subsidiar corporations for the actual carrring on of their immediate lamful business. or the natural and legitimate branches or extensions thereof. or from omning and holding all or a part of the stock of such subsidiary corporations. when the effect of such formation is not to substantially lessen competition. 
Nor shall anything herein contained be construed to prohibit any common carrier subject to the laws to regulate commerce from aiding in the construction of branches carriersmay or short lines so located as to become feeders to the main com petitive line of the company so aiding in such construction or
short lines. from acquiring or owning all or any part of the stock of such branch lines. nor to prevent any such common carrier from acquiring and owning all or any part of the stock of a branch or short line constructed by an independent company where there is no substantial competition between the company owning the branch line so constructed and the company orning the main line acquiring the property or an interest therein, nor to prerent such common carrier from extending any of its lines through the medium of the acquisition of stock or otherwise of any other such common carrier where there is no substantial competition between the company extending its lines and the company whose stock, property, or an interest therein is so acquired.

Antitrust Nothing contained in this section shall be held to affect
not repealed. or impair any right heretofore legally acquired: Pro. vided. That nothing in this section shall be held or construed to authorize or make lawful anything heretofore prohibited or made illegal by the antitrust laws, nor to exempt any person from the penal provisions thereof or the civil remedies therein provided.

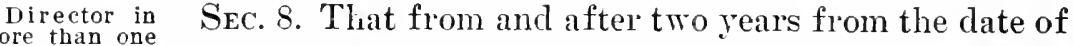
cank of large the approval of this Act no person shall at the same time ited.

be a director or other officer or employee of more than one bank, banking association or trust company, organized or operating under the laws of the United States, either of which has deposits, capital, surplus, and undivided profits aggregating more than $\$ 5,000,000$; and no private banker or person who is a director in any bank or trust company, organized and operating under the laws of a State, having deposits, capital, surplus, and undirided profits aggregating more than $\$ 5,000,000$, shall be eligible to be a director in any bank or banking association organized or operating under the laws of the Eligibility of United States. The eligibility of a director, officer, or
offcer. employee under the foregoing provisions shall be determined by the arerage amount of cleposits, capital, surplus, and undivided profits as shown in the official statements of such bank, banking association, or trust company filed 
as provided by law during the fiscal year next preceding the date set for the annual election of directors, and when a director, officer, or employee has been elected or selected in accordance with the provisions of this Act it shall be lawful for him to continue as such for one year thereafter under said election or employment.

No bank, banking association or trust company, organized or operating under the laws of the United States, cannotserrein in any city or incorporated town or village of more than two hundred thousand inhabitants, as shown by the last preceding decennial census of the United States, shall have as a director or other officer or employee any private banker or any director or other officer or employee of any other bank, banking association or trust company located in the same place: Provided, That nothing in this section shall apply to mutual savings banks not having a capital stock represented by shares: Provided further, That a director or other officer or employee of such bank, banking association, or trust company may be a director or other officer or employee of not more than one other bank or trust company organized under the laws of the United States or any State where the entire capital stock of one is owned by stockholders in the other: And provided further, That nothing contained in this section shall forbid a director of class $\mathbf{A}$ of a Federal reserve bank, as defined in the Federal Reserve Act from being an officer or director or both an officer and director in one member bank.

That from and after two years from the date of the approval of this Act no person at the same time shall be se director in a director in any two or more corporations, any one of corporations. which has capital, surplus, and undivided profits aggregating more than $\$ 1,000,000$, engaged in whole or in part in commerce, other than banks, banking associations, trust companies and common carriers subject to the Act to regulate commerce, approved February fourth, eighteen hundred and eighty-seven, if such corporations are or shall have been theretofore, by virtue of their business and location of operation, competitors, so that the elimination of competition by agreement between them would constitute a violation of any of the provisions of any of the antitrust laws. The eligibility of a director under the foregoing provision shall be determined by the aggregate amount of the capital, surplus, and undivided profits, ex- 
clusive of dividends declared but not paid to stockholders, at the end of the fiscal year of said corporation next preceding the election of directors, and when a-director has been elected in accordance with the provisions of this Act it shall be lawful for him to continue as such for one year thereafter.

l'resent reli: tions may exist for one year.

When any person elected or chosen as a director or oflicer or selected as an employee of any bank or other corporation subject to the provisions of this Act is eligible at the time of his election or selection to act for such bank or other corporation in such capacity his eligibility to act in such capacity shall not be affected and he shall not become or be deemed amenable to any of the provisions hereof by reason of any change in the affairs of such bank or other corporation from whatsoever cause, whether specifically excepted by any of the provisions hereof or not, until the expiration of one year from the clate of his election or employment.

E m bezzle-
ment of funds. of any firm, association or corporation engaged in commerce as a common carrier, who embezzles, steals, abstracts or willfully misapplies, or willfully permits to be misapplied, any of the moneys, funds, credits, securities, property or assets of such firm, association or corporation, arising or accruing from, or used in, such commerce, in whole or in part, or willfully or knowingly converts the same to his own use or to the use of another, shall be deemed guilty of a felony and upon conviction shall be fined not less than $\$ 500$ or confined in the penitentiary not less than one year nor more than ten years, or both, in the discretion of the court.

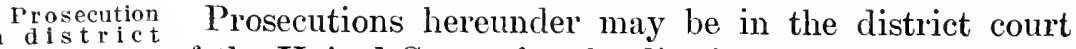
courts. of the United States for the district wherein the offense may have been committed.

state courts. That nothing in this section shall be held to take away or impair the jurisdiction of the courts of the several States under the laws thereof; and a judgment of conviction or acquittal on the merits under the laws of any State shall be a bar to any prosecution hereunder for the same act or acts.

Carrier pro-
ibited SEcom 10 . That after two years from the approval of this pulcec a sing
from another corporation any dealings in securities, supplies or other articles of
having same officers.

commerce, or shall make or have any contracts for construction or maintenance of any kind, to the amount of 
more than $\$ 50,000$, in the aggregate, in any one year, with another corporation, firm, partnership or association when the said common carrier shall have upon its board of director's or as its president, manager or as its purchasing or selling officer, or agent in the particular transaction, any person who is at the same time a director, manager, or purchasing or selling officer of, or who has any substantial interest in, such other corporation, firm, partnership or association, unless and except such purchases shall be made from, or such dealings shall be with, the bidder whose bid is the most favorable to such common carrier, to be ascertained by competitive bidding under regulations to be prescribed by rule or otherwise by the Interstate Commerce Commission. No bid shall $\begin{gathered}\text { Bids super- } \\ \text { vised by the }\end{gathered}$ be received unless the name and address of the bidder or commission. the names and addresses of the officers, directors and general managers thereof, if the bidder be a corporation, or of the members, if it be a partnership or firm, be given with the bid.

Any person who shall, directly or indirectly, do or Penalty. attempt to do anything to prevent anyone from bidding or shall do any act to prevent free and fair competition among the bidders or those desiring to bid shall be punished as prescribed in this section in the case of an officer or director.

Every such common carrier having any such transactions or making any such purchases shall within thirty made to comdays after making the same file with the Interstate Commerce Commission a full and detailed statement of the transaction showing the manner of the competitive bidding, who were the bidders, and the names and addresses of the directors and officers of the corporations and the members of the firm or partnership bidding; and whenever the said Commission shall, after investigation or hearing, have reason to believe that the law has been violated in and about the said purchases or transactions it shall transmit all papers and documents and its own views or findings regarding the transaction to the Attorney General.

If any common carrier shall violate this section it shall renalty. be fined not exceeding $\$ 25,000$; and every such director, agent, manager or officer thereof who shall have knowingly voted for or directed the act constituting such violation or who shall have aided or abetted in such violation 
shall be deemed guilty of a misdemeanor and shall be fined not exceeding $\$ 5,000$, or confined in jail not exceeding one year, or both, in the discretion of the court.

Authority of SEc. 11. That authority to enforce compliance with sion.

sections two, three, seren and eight of this Act by the persons respectively subject thereto is hereby vested: in the Interstate Commerce Commission where applicable to common carriers, in the Federal Reserve Board where applicable to banks, banking associations and trust companies, and in the Federal Trade Commission where applicable to all other character of commerce, to be exercised as follows:

rrocedure. Whenever the Commission or board vested with jurisdiction thereof shall have reason to believe that any person is violating or has violated any of the provisions of sections two, three, seven and eight of this Act, it shall issue and serve upon such person a complaint stating its charges in that respect, and containing a notice of a hearing upon a day and at a place therein fixed at least thirty days after the service of said complaint. The first so complained of shall have the right to appear at the place and time so fixed and show cause why an order should not be entered by the Commission or board requiring such person to cease and desist from the violation Interveners. of the law so charged in said complaint. Any person may make application, and upon good cause shown may be allowed by the Commission or board, to intervene and appear in said proceeding by counsel or in person. The testimony in any such proceeding shall be reduced to writing and filed in the office of the Commission or board.

Hearings. If upon such hearing the Commission or board, as the case may be, shall be of the opinion that any of the provisions of said sections have been or are being violated, it shall make a report in writing in which it shall state its findings as to the facts, and shall issue and cause to be

order. served on such person an order requiring such person to cease and desist from such violations, and divest itself of the stock held or rid itself of the directors chosen contrary to the provisions of sections seven and eight of this Act, if any there be, in the manner and within the Rehearings. time fixed by said order. Until a transcript of the record in such hearing shall have been filed in a circuit court of appeals of the United States, as hereinafter provided, the Commission or board may at any time, upon such notice 
and in such manner as it shall deem proper, modify or set aside, in whole or in part, any report or any order made or issued by it under this section.

If such person fails or neglects to obey such order of may appission the Commission or board while the same is in effect, the courts.

Commission or board may apply to the circuit court of appeals of the United States, within any circuit where the violation complained of was or is being committed or where such person resides or carries on business, for the enforcement of its order, and shall certify and file with its application a transcript of the entire record in the proceding, including all the testimony taken and the report and order of the Commission or board. Upon such filing of the application and transcript the court shall cause notice thereof to be served upon such person and thereupon shall have jurisdiction of the proceeding and of the question determined therein, and shall have power to make and enter upon the pleadings, testimony, and proceedings set forth in such transcript a decree affirming, modifying, or setting aside the order of the Commission or board. The findlings of the Commission fact. or board as to the facts, if supported by testimony, shall be conclusive. If either party shall apply to the court eridence. for leave to adduce additional evidence, and shall show to the satisfaction of the court that such additional evidence is material and that there were reasonable grounds for the failure to adduce such evidence in the proceeding before the Commission or board, the court may order such additional evidence to be taken before the Commission or board and to be adduced upon the hearing in such manner and upon such terms and conditions as to the court may seem proper. The Commission or board may modify its findings as to the facts, or make new findings, by reason of the additional evidence so taken, and it shall file such modified or new findings, which, if supported by testimony, shall be conclusive, and its recommendation, if any, for the modification or setting aside of its original order, with the return of such additional evidence. The judgment and decree of the court shall be $\begin{gathered}\text { Reriew by } \\ \text { Supreme court. }\end{gathered}$ final, except that the same shall be subject to review by the Supreme Court upon certiorari as provided in section two hundred and forty of the Judicial Code.

Any party required by such order of the Commission a parrier $\operatorname{mas}_{\mathrm{t}}^{\text {mas }}$ or board to cease and desist from a violation charged may courts. obtain a review of such order in said circuit court of 
appeals by filing in the court a written petition praying that the order of the Commission or board be set aside. A copy of such petition shall be forthwith served upon the Commission or board, and thereupon the Commission or board forthwith shall certify and file in the court a irucedure. transcript of the record as hereinbefore provided. Upon the filing of the transcript the court shall have the same jurisdiction to affirm, set aside, or modify the order of the Commission or board as in the case of an application by the Commission or board for the enforcement of its Findings of order, and the findings of the Commission or board as to the facts, if supported by testimony, shall in like manner be conclusive.

Jurisdiction The jurisdiction of the circuit court of appeals of the of courts. United States to enforce, set aside, or modify orders of the Commission or board shall be exclusive.

rrecedener. Such proceedings in the circuit court of appeals shall be given precedence over other cases pending therein, and shall be in every way expedited. No order of the Commission or board or the judgment of the court to enforce the same shall in any wise relieve or absolve any person from any liability under the antitrust Acts.

Complaints, orders, and other processes of the ComService of mission or board under this section may be served by anyone duly anthorized by the Commission or board, either (a) by delivering a copy thereof to the person to be served, or to a member of the partnership to be served, or to the president, secretary, or other executive officer or a director of the corporation to be served; or (b) by leaving a copy thereof at the principal office or place of business of such person; or (c) by registering and mailing a copy thereof addressed to such person at his principal office or place of business. The rerified return by the person so serving said complaint, order, or other process setting forth the manner of said service shall be proof of the same, and the return post-office receipt for said complaint, order, or other process registered and mailed as aforesaid shall be proof of the service of the same.

$$
\text { * * * * * * * }
$$

SEc. 15. That the several district courts of the United Iurisdiction States are hereby invested with jurisdiction to prevent
courts. and restrain violations of this Act, and it shall be the duty of the several district attorneys of the United States, in their respective districts, under the direction of the Attorney General, to institute proceedings in 
equity to prevent and restrain such violations. Such proceedings may be by way of petition setting forth the case and praying that such violation shall be enjoined or otherwise prohibited. When the parties complained of shall have been duly notified of such petition, the court shall proceed, as soon as may be, to the hearing and determination of the case; and pending such petition, and before final decree, the court may at any time make such temporary restraining order or prohibition as shall be deemed just in the premises. Whenerer it shall appear to the court before which any such proceeding may be pending that the endis of justice require that other parties should be brought before the court, the court may cause them to be summoned, whether they reside in the district in which the court is held or not, and subpœnas to that end may be served in any district by the marshal thereof.

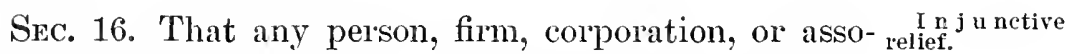
ciation shall be entitled to sue for and have injunctive relief, in any court of the United States having juris diction over the parties, against threatened loss or dam. age by a violation of the antitrust laws, including sections two, three, seven and eight of this Act, when and under the same conditions and principles as injunctive relief against threatened conduct that will cause loss or damage is granted by courts of equity, under the rules governing such proceedings, and upon the execution of proper bond against damages for an injunction improvidently granted and a showing that the danger of irreparable loss or damage is immediate, a preliminary injunction may issue: Provided, That nothing herein contained shall be construed to entitle any person, firm, corporation, or association, except the United States, to bring suit in equity for injunctive relief against any common carrier subject to the provisions of the Act to regulate commerce, approved February fourth, eighteen hundred and eighty-seven, in respect of any matter subject to the regulation, supervision, or other jurisdiction of the Interstate Commerce Commission.

Src. 17. That no preliminary injunction shall be issued without notice to the opposite party.

No temporary restraining order shall be granted with- order. out notice to the opposite party unless it shall clearly appear from specific facts shown by affidavit or by the

Procedure.

Hearings.

l'arties.

Bond.

United States only may seek in junction liers.

Notice. 
Irredarable injurr.

Hearings.

reritied bill that immediate and irreparable injury, loss, or damage will result to the applicant before notice can be served and a hearing had thereon. Erery such temporary restraining order shall be indorsed with the date and hour of issuance, shall be forthwith filed in the clerk's office and entered of record, shall define the injury and state why it is irreparable and why the order was granted without notice: and shall by its terms expire within such time after entry, not to exceed ten days, as the court or judge mar fix, unless within the time so fixed the order is extended for a like period for good cause shomn. and the reasons for such extension shall be entered of record. In case a temporary restraining order shall be granted without notice in the contingency specifiecl. the matter of the issuance of a preliminary injunction shall be set down for a hearing at the earliest possible time and shall take precedence of all matters except older matters of the same character; and when the same comes up for hearing the party obtaining the temporary restraining order shall proceed with the application for a preliminary injunction. and if he does not do so the court shall dissolve the temporary restraining order.

Dissolution. ¿pon tro days notice to the party obtaining such temporary restraining order the opposite party may appear and more the dissolution or modification of the order, and in that erent the court or judge shall proceed to hear and letermine the motion as expeditionsly as the ends of justice mar require.

Bond.

SEC. 18. That, except as otherwise provided in section 16 of this Act, no restraining order or interlocutory order of injunction shall issue, except upon the giving of security by the applicant in such sum as the court or judge mar deem proper, conditioned upon the payment of such costs and damages as may be incurred or suffered by any party who may be found to have been wrongfully enjoined or restrained thereby.

Specific rea. sons for and notice of application.

SEC. 19. That every order of injunction or restraining order shall set forth the reasons for the issuance of the same, shall be specific in terms, and shall describe in reasonable detail, and not by reference to the bill of complaint or other document, the act or acts sought to be restrained, and shall be binding only upon the parties to the suit, their officers, agents, serrants, employees, and 
attorneys, or those in active concert or participating with them, and who shall, by personal service or otherwise, hare received actual notice of the same.

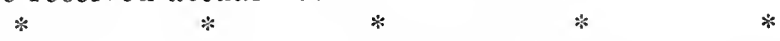

SEC. 26. If any clause, sentence, paragraph, or part of $\begin{gathered}\text { If } \\ \text { part }\end{gathered}$ held this Act shall, for any reason, be adjudged by any court varti in other of competent jurisdiction to be invalid, such judgment be affected. shall not affect, impair, or invalidate the remainder thereof, but shall be confined in its operation to the clause, sentence, paragraph, or part thereof directly inrolved in the controversy in which such judgment shall have been rendered.

Public, No. 212, approved October 15, 1914.

\section{GOVERNMENT-AIDED RAILROAD AND TELEGRAPH ACT'.}

AN ACT Supplementary to the Act of Juls first, eighteen hundred and sixtr-two, entitled "Au Act to aid in the construction of a railroad and telegraph line from the Missouri River to the Pacific Ocean, and to secure to the Gorernment the use of the sime for postal, military. and other purposes," and also of the Act of July second, eighteen hundred and sixty-four, and other Acts amendatory of said first-named Act.

Be it enacted by the Senate and House of Representatives of the United States of America in Congress assemb7ed, That all railroad and telegraph companies to which the United States has granted any subsidy in lands or and telegraph bonds or loan of credit for the construction of either rail lines must road or telegraph lines, which, by the tets incorpating maintain and them, or by any Act amendatory or supplementary thereto, are required to construct, maintain, or operate telegraph lines, and all companies engaged in operating said railroad or telegraph lines shall forthwith and henceforward, by and through their own respective corporate officers and employees, maintain and operate, for railroad, gorernmental, commercial, and all other purposes, telegraph lines, and exercise by themselres alone all the telegraph franchises conferred upon them and obligations assumed by them under the Acts making the grants as aforesaid.

SEc. 2. That whenerer any telegraph company which Connecting shall have accepted the provisions of title sixty-five of lines. the Rerised Statutes shall extend its line to any station or office of a telegraph line belonging to any one of said railroad or telegraph companies, referred to in the first section of this Act, said telegraph company so extending its line shall have the right and said railroad or telegraph company shall allow the line of said telegraph company so extending its line to connect with the telegraph line of 
said railroad or telegraph company to which it is extended at the place where their lines may meet, for the prompt and convenient interchange of telegraph business Equal facili- between said companies; and such railroad and telegraph
ies required. companies, referred to in the first section of this Act, shall so operate their respective telegraph lines as to afford equal facilities to all, without discrimination in faror of or against any person, company, or corporation whatever, and shall receive, deliver, and exchange business with connecting telegraph lines on equal terms, and affording equal facilities, and withont discrimination for or against any one of such connecting lines; and such exchange of business shall be on terms just and equitable.

Complaints to interstate Com merce commision. commission merce Commission, whose duty it shall thereupon be, SEc. 3. That if any such railroad or telegraph company referred to in the first section of this Act or company operating such railroad or telegraph line shall refuse or fail, in whole or in part, to maintain and operate a telegraph line as provided in this Act and Acts to which this is supplementary, for the use of the Government or the public, for commercial and other purposes, without discrimination, or shall refuse or fail to make or continue such arrangements for the interchange of busi. ness with any connecting telegraph company, then any person, company, corporation, or connecting telegraph company may apply for relief to the Interstate Comwhaint is made. prescribe, to ascertain the facts, and determine and order what arrangement is proper to be made in the particular case, and the railroad or telegraph company concerned shall abide by and perform such order; and it shall be the duty of the Interstate Commerce Commission, when such determination and order are made, to notify the parties concerned, and, if necessary, enforce the same by writ of mandamus in the courts of the Tnited States, in the name of the United States, at the relation of either of said Interstate Commerce Commiscommission a yinstitute sioners: Provided, That the said Commissioners may inm a yinstitites on its stitute any inquiry, upon their own motion, in the same
own notion.
manner and to the same effect as though complaint had been made.

Duty of the Attorney General under this

SEC. 4. That in order to secure and preserve to the Act.

United States the full value and benefit of its liens upon all the telegraph lines required to be constructed by and 
lawfully belonging to said railroad and telegraph companies referred to in the first section of this Act, and to have the same possessed, used, and operated in conformity with the provisions of this Act and of the several Acts to which this Act is supplementary, it is hereby made the duty of the Attorney General of the United States, by proper' proceedings, to prevent any unlawful interference with the rights and equities of the United States under this Act, and under the Acts hereinbefore mentioned, and under all Acts of Congress relating to such railroads and telegraph lines, and to have legally ascertained and finally adjudicated all alleged rights of all persons and corporations whaterer claiming in any manner any control or interest of any kind in any telegraph lines or property, or exclusive rights of way upon the lands of said railroad companies, or any of them, and to have all contracts and provisions of contracts set aside and annulled which have been unlawfully and beyond their power's entered into by said railroad or telegraph companies, or any of them, with any other person, company, or corporation.

Sec. 5. That any officer or agent of said railroad or failure to comtelegraph companies, or of any company operating the ply with the railroads and telegraph lines of said companies, who shall this Act or the refuse or fail to operate the telegraph lines of said rail- $\mathrm{I}_{\mathrm{C}} \mathrm{terstate}$ road or telegraph companies under his control, or which commission. he is engaged in operating, in the manner directed in this Act and by the Acts to which it is supplementary, or who shall refuse or fail, in such operation and use, to afford and secure to the Government and the public equal facilities, or to secure to each of said connecting telegraph lines equal adrantages and facilities in the interchange of business, as herein provided for, without any discrimination whaterer for or adverse to the telegraph line of any or either of said connecting companies, or shall refuse to abicle by, or perform and carry ont within a reasonable time the order or orders of the Interstate Commerce Commission, shall in every such case of refusal or failure be guilty of a misdemeanor, and, on conviction thereof, shall in every such case be fined in a sum not exceeding one thousand dollars, and may be imprisoned not less than six months; and in every such case of refusal or failure the party aggrieved may not only cause the officer or agent guilty thereof to be prosecuted under the provisions of 
Actions for this section, but may also bring an action for the damages may alyo be sustained thereby against the company whose officer or
broight. agent may be guilty thereof, in the circuit or district court of the United States in any State or Territory in which any portion of the road or telegraph line of said company may be situated; and in case of suit process may be served upon any agent of the company found in such State or Territory; and such service shall be held by the court good and sufficient.

Duty of rail- SEc. 6 . That it shall be the duty of each and erery one
oad and telegraph 1 i ne $\mathrm{res}$ of the aforesaid railroad and telegraph companies, within Act to tile cop-sixty dars from and after the passage of this Act, to file ies of contracts sixty days from and after the passage of this Act, to fle and i report with the Interstate Commerce Commission eopies of all mission. contracts and agreements of every description existing between it and every other person or corporation whatsoerel in reference to the omnership, possession, maintenance, control, use, or operation of any telegraph lines, or property over or upon its rights of way, and also a report describing with sufficient certainty the telegraph lines and property belonging to it, and the manner in which the same are being then used and operated by it, and the telegraph lines and property upon its right of way in which any other person or corporation claims to have a title or interest, and setting forth the grounds of such claim, and the manner in which the same are being then Annual re-used and operated; and it shall be the duty of each and ports to the
Commission. ally hereafter to report to the Interstate Commerce Commission. with reasonable fullness and certainty, the nature. extent, value, and condition of the telegraph lines and property then belonging to it, the gross earnings, and all expenses of maintenance, use, and operation thereof, and its relation and business with all connecting telegraph companies during the preceding year, at such time and in such manner as may be required by a system of reports Penalties for which said Commission shall prescribe; and if any of refusal to make
reports to Com-said railroad or telegraph companies shall refuse or fail
mission. to make such reports or any report as may be called for by said Commission, or refuse to submit its books and records for inspection, such neglect or refusal shall operate as a forfeiture, in each case of such neglect or refusal, of a sum not less than one thousand dollars nor more than five thousand dollars, to be recorered by the Attorney General of the United States, in the name and for the use 
and benefit of the United States; and it shall be the duty Duty of Atof the Interstate Commerce Commission to inform the to prosecute.

Attorney General of all such cases of neglect or refusal, whose duty it shall be to proceed at once to judicially enforce the forfeitures hereinbefore provided.

SEC. 7. That nothing in this Act shall be construed to - Right of Conaffect or impair the right of Congress, at any time here- areasd, or reafter, to alter, amend, or repeal the said acts hereinbefore mentioned; and this Act shall be subject to alteration, amendment, or repeal as, in the opinion of Congress justice or the public welfare may require; and nothing of Equity rights

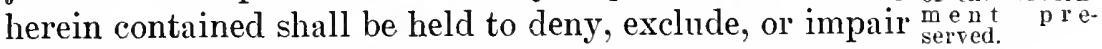
any right or remedy in the premises now existing in the United States, or any authority that the Postmaster General now has under title sixty-five of the Revised Statutes to fix rates, or, of the Government, to purchase lines as provided under said title, or to have its messages given precedence in transmission.

Public, No. 237, approved August 7, 1888.

\section{LAKE ERIE AND OHIO RIVER SHIP CANAL,}

AN ACT To incorporate the Lake Erie and Ohio River Ship Canal.

to define the powers thereof, and to facilitate interstite commerce.

* $\quad * \quad * \quad * \quad * \quad * \quad *$

SEc. 17. That the said canals shall be open to the use and navigation of all suitable and proper vessels or other water craft, by whomsoerer owned or operated, upon fair and equal terms, conditions, rates, tolls, and charges; and the said company may demand, take, and recorer for its own proper use, for all persons and things of whatsoever description transported upon the said canals, feeders, and other works, or in ressels and craft using the same, just and reasonable charges, rates, and tolls; but all such charges, rates, and tolls shall be equal to all $\begin{gathered}\text { Charges shall } \\ \text { be reasonable. }\end{gathered}$ persons, vessels, and goods under certain classifications to be established by the company and approved by the Interstate Commerce Commission; and no rebate, reduction, drawback, or discrimination of any sort on such charges, rates, and tolls shall ever be made directly or indirectly. And the said charges, rates, and tolls for the Publication ensuing year shall be fixed, published, and posted on or in every place where they are to be collected, on or before

Charges to be approved by Commission. 
the fifteenth day of February of each year, and shall not be changed except after thirty days' public notice, which notice shall plainly state the changes proposed to be made in the charges, rates, and tolls then in force and the time when the changed charges. rates, and tolls will go into effect; and the proposed changes shall be shown by printing new schedules or shall be plainly indicated upon the schedules in force at the time and kept open to public mammission inspection: Provided, That the Interstate Commerce quirements. Commission may, in its discretion and for good cause shown, allow changes upon less notice than herein specified or modify the foregoing requirements in respect to publishing and posting of such schedules, either in particular instances or by a general order applicable to special or peculiar circumstances or conditions.

s:

Public, No. 402, approved June 30, 1906.

\section{PARCEL POST.}

AN AC"I Making appropriations for the service of the Post Office Department for the fiscal year ending June thirtieth, nineteen hundred and thirteen, and for other purposes.

$$
\text { SEc. 8. (Parcel Post.) }
$$

* * * * * *

consent of The classification of articles mailable as well as the sion to changes- weight limit, the rates of postage, zone or zones and other in parcel post. conditions of mailability under this Act, if the Postmaster General shall find on experience that they or any of them are such as to prevent the shipment of articles desirable, or to permanently render the cost of the service greater than the receipts of the revenue therefrom, he is hereby authorized, subject to the consent of the Interstate Commerce Commission after investigation, to reform from time to time such classification, weight limit, rates, zone or zones or conditions, or either, in order to promote the service to the public or to insure the receipt of revenue from such service adequate to pay the cost thereof.

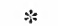

Public, No. 336, approved August 24, 1912. 


\section{SAFETY APPLIANCE ACTS.}

AN ACT To promote the safety of employees and travelers upon railroads by compelling common carriers engaged in interstate commerce to equip their cars with automatic couplers and continuous brakes and their locomotives with driving-wheel brakes, and for other purposes.

Be it enacted by the Senate and House of Representatives of the United States of Americn in Congress assembled, That from and after the first day of January, Driving. eighteen hundred and ninety-eight, it shall be unlawful wrakes. for any common carrier engaged in interstate commerce by railroad to use on its line any locomotive engine in moving interstate traffic not equipped with a power driving-wheel brake and appliances for operating the trainbrake system, or to run any train in such traffic after said date that has not a sufficient number of cars in it so equipped with power or train brakes that the engineer on the locomotive drawing such train can control its speed without requiring brakemen to use the common hand brake for that purpose.

SEC. 2. That on and after the first day of January, automatic ejghteen hundred and ninety-eight, it shall be unlawful for any such common carrier to haul or permit to be hauled or used on its line any car used in moving interstate traffic not equipped with couplers coupling automatically by impact, and which can be uncoupled without the necessity of men going between the ends of the cars.

SEC. 3. That when any person, firm, company, or corporation engaged in interstate commerce by railroad shal

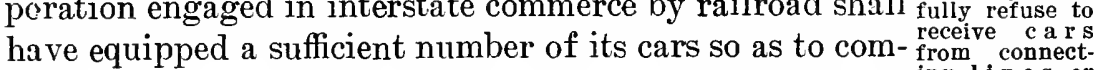
ply with the provisions of section one of this Act, it may ing $\operatorname{lin}$ shipers lawfully refuse to receive from connecting lines of road or shippers any cars not equipped sufficiently, in accordance with the first section of this Act, with such power or train brakes as will work and readily interchange with the brakes in use on its own cars, as required by this Act.

SEc. 4. That from and after the first day of July, G r a b irons eighteen hundred and ninety-five, until otherwise ordered and handholds. 
Standard height of draw. cars.

by the Interstate Commerce Commission, it shall be unlawful for any railroad company to use any car in interstite commerce that is not provided with secure grab irons or handholds in the ends and sides of each car for greater security to men in coupling and uncoupling cars.

SEc. 5. That within ninety days from the passage of hereby to designate to the Interstate Commerce Commission the standard height of drawbars for freight cars, measured perpendicular from the lerel of the tops of the rails to the centers of the drawbars. for each of the several gauges of railroads in use in the United States, and shall fix a maximum rariation from such standard height to be allowed between the drawbars of empty and loaded cars. Upon their determination being certified to the Interstate Commerce Commission. saicl Commission shall at once give notice of the standard fixed upon to all common carriers, owners, or lessees engaged in interstate commerce in the United States by such means as the Commission may deem proper. But should said association fail to determine a standard as above provided, it shall be the duty of the Interstate Commerce Commission to do so, before July first, eighteen hundred and ninetyfour, and immediately to give notice thereof as aforesaid. And after July first, eighteen hundred and ninety-five, no cars, either loaded or mloaded, shall be used in interstate traffic which do not comply with the standard above provided for.

Peralty. SEC. 6. (As amended A prit 1, 1896.) That any such common carrier using any locomotive engine, running any train, or hauling or permitting to be hauled or used on its line any car in riolation of any of the provisions of this Act. shall be liable to a penalty of one hundred dollars for each and every such violation, to be recovered in a suit or suits to be brought by the United States district attorney in the district court of the United States having jurisdiction in the locality where such violation shall have been committed; and it shall be the duty of such district attorney to bring such suits upon duly rerified information being lodged with him of such violation having occurred; and it shall also be the duty of the Interstate Commerce Commission to lodge with the proper district attorneys information of any such viola-

Exceptions to tions as may come to its knowledge: Provided, That noth-
he act. ing in this Act contained shall apply to trains composed of four-wheel cars or to trains composed of eight-wheel 
standard logging cars where the height of such car from top of rail to center of coupling does not exceed trentyfive inches, or to locomotives used in hauling such trains when such cars or locomotives are exclusirely used for the transportation of logs.

Sec. 7. That the Interstate Commerce Commission may Power of Infrom time to time upon full hearing and for good cause merce commis. extend the period within which any common carrier shall sion to extend comply with the provisions of this Act. er's to comply with this act.

SEc. 8. That any employee of any such common carrier who may be injured by any locomotive, cal, or train in assume risk of use contrary to the provisions of this Act shall not be deemed thereby to have assumed the risk thereby occasioned, although continuing in the employment of such carrier after the unlawful use of such locomotive, car, or train had been brought to his knowledge.

Public, No. 113, approved March 2, 1893, amended April 1, 1896.

Noтf-Prescribed standard height of drawbars: Standard-gauge railroads: maximum $34 \frac{1}{2}$, minimum $31 \frac{1}{2}$, inches; narrow-gauge railroads: maximum 26, minimum 23. inches; 2 -foot-gauge railroads: maximum $17 \frac{1}{2}$, minimum $14 \frac{1}{2}$, inches.

AN ACT To amend an Act entitled "An Act to promote the safety of emplosees and travelers upon railroads by compelling common carriers engaged in interstate commerce to equip their cars with automatic couplers and continuous brakes and their locomotires with driving-wheel brakes. and for other purposes," approved March second, eighteen hundred and nivety-three, and amended April first, eighteen hundred and nivety-six.

Be it enacted by the Senate and House of Representrtives of the United States of America in Congress assembled, That the provisions and requirements of the Act entitled "An Act to promote the safety of employees and Mar. travelers upon railroads by compelling common carriers act of apr. 1 , engaged in interstate commerce to equip their cars with ply in Terrien tories and Disautomatic couplers and continuous brakes, and their loco-trict of Colummotives with driving-wheel brakes, and for other pur- Prorisions of poses," approved March second, eighteen hundred and ance acts as to pinety ninety-three, and amended April first, eighteen hundred apply in all and ninety-six, shall be held to apply to common carrierscoup cers are by railroads in the Territories and the District of Co-gether. lumbia and shall apply in all cases, whether or not the couplers brought together are of the same kind, make, or type; and the provisions and requirements hereof and of $66170^{\circ}-14-6$ 


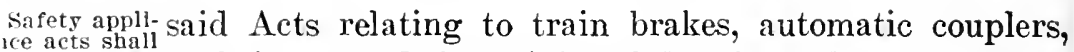
ance acts shall grab irons, and the height of drawbars shall be held to

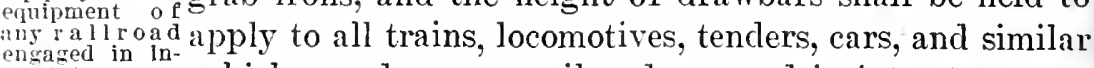
terstate com-vehicles used on any railroad engaged in interstate com-
merce. merce, and in the Territories and the District of Columbia, and to all other locomotives, tenders, cars, and similar Exceptions. rehicles ased in connection therewith, excepting those trains, cars, and locomotives exempted by the provisions of section six of said Act of March second, eighteen hundred and ninety-three, as amended by the Act of April first, eighteen hundred and ninety-six, or which are used upon street railways.

Power brakes. SEc. 2. That whenever, as provided in said Act, any train is operated with power or train brakes, not less than fifty per centum of the cars in such train shall have their brakes used and operated by the engineer of the locomotive drawing such train; and all power-braked cars in such train which are associated together with said fifty per centum shall have their brakes so used and operated; and, to more fully carry into effect the objects of said Act,

commission the Interstate Commerce Commission may, from time to minimum per- time, after full hearing, increase the minimum percentage centage of of cars in any train required to be operated with power or lirake cars to train brakes which must have their brakes used and oper-
be used. ated as aforesaid; and failure to comply with any such requirement of the said Interstate Commerce Commission Penalty. shall be subject to the like penalty as failure to comply with any requirement of this section.

SEC. 3. That the provisions of this Act shall not take effect until September first, nineteen hundred and three. Nothing in this Act shall be held or construed to relieve rrovisions, any common carrier, the Interstate Commerce Commispowers, duties, sion, or any United States district attorney from any of and $l i a$ bilities the provisions, powers, duties, liabilities, or requirements
speclied in act of and act of $A$ pr.
1 to 1896 , apply
to this act. dred and ninety-six; and all of the provisions, powers, duties, requirements, and liabilities of said Act of March second, eighteen hundred and ninety-three, as amended by the Act of April first, eighteen hundred and ninety-six, shall, except as specifically amended by this Act, apply to this Act.

Public, No. 133, approved March 2, 1903. 
AN ACT To supplement "An Act to promote the safety of employees and travelers upon railroads by cómpelling common carriers engaged in interstate commerce to equip their cars with automatic couplers and continuous brakes and their locomotives with driving wheel brakes and for other purposes," and other safety appliance Acts, and for other purposes.

Be it enacted by the Senate and House of Representatives of the United States of America in Congress assembled, That the provisions of this Act shall apply to To what carevery common carrier and every vehicle subject to the ble.

Act of March second, eighteen hundred and ninety-three, as amended April first, eighteen hundred and ninety-six, and March second, nineteen hundred and three, commonly known as the "Safety Appliance Acts."

SEC. 2. That on and after July first, nineteen hundred and eleven, it shall be unlawful for any common carrier subject to the provisions of this Act to haul, or permit to be hauled or used on its line any car subject to the provisions of this Act not equipped with appliances provided for in this Act, to wit: All cars must be equipped with for in this Act, to wit: All cars must be equipped with Cars to be
secure sill steps and efficient hand brakes; all cars re- sill speed with
brakes, hand
baders, quiring secure ladders and secure running boards shall $r$ a $\mathrm{u}_{\mathrm{n}} \mathrm{n} i \mathrm{i}$, be equipped with such ladders and running boards, and grab a ds, and all cars having ladders shall also be equipped with secure hand holds or grab irons on their roofs at the tops of such ladders: Provided, That in the loading and hauling of long commodities, requiring more than one car, the hand brakes may be omitted on all save one of the cars while thiey are thus combined for such purpose.

Sec. 3. That within six months from the passage of this to demmission Act the Interstate Commerce Commission, after hearing, number, dimenshall dèsignate the number, dimensions, location, and and manner of manner of application of the appliances provided for by appliances. section two of this Act and section four of the Act of March second, eighteen hundred and ninety-three, and shall give notice of such designation to all common carriers subject to the provisions of this Act by such means as the Conmission may deem proper, and thereafter said number, location, dimensions, and manner of application as designated by said Commission shall remain as the standards of equipment to be used on all cars subject to the provisions of this Act, unless changed by an order of said Interstate Commerce Commission, to be made after full hearing and for good cause shown; and failure to comply with any such requirement of the Interstate Com- 
merce Commission shall be subject to a like penalty as Period of failure to comply with any requirement of this Act: Promay be ex-vided, That the Interstate Commerce Commission may, tended.

upon full hearing and for good cause, extend the period within which any common carrier shall comply with the provisions of this section with respect to the equipment of cars actually in service upon the date of the passage Commission of this Act. Said Commission is hereby given authority, height of draw-after hearing, to modify or change, and to prescribe the
bars.

standard height of drawbars and to fix the time within which such modification or change shall become effective and obligatory, and prior to the time so fixed it shall be $r$ ress e $t$ unlawful to use any car or vehicle in interstate or foreign height of draw-traffic which does not comply with the standard now fixed bars legal.

or the standard so prescribed, and after the time so fixed it shall be unlawful to use any car or vehicle in interstate or foreign traffic which does not comply with the standard so prescribed by the Commission.

Penalty for SEc. 4. That any common carrier subject to this Act provisions of using, hauling, or permitting to be used or hauled on its
this Act.

line any car subject to the requirements of this Act not equipped as provided in this Act shall be liable to a penalty of one hundred dollars for each and every such violation, to be recovered as provided in section six of the Act of March second, eighteen hundred and ninety-three, as amended April first, eighteen hundred and ninety-six: Provided, That where any car shall have been properly equipped, as provided in this Act and the other Acts mentioned herein, and such equipment shall have become Defective cars defective or insecure while such car was being used by
may be hauled may be haled no carrier upon its line of railroad, such car may be pair point. ${ }^{\text {a }}$ hauled from the place where such equipment was first discovered to be defective or insecure to the nearest available point where such car can be repaired, without liability for the penalties imposed by section four of this Act or section six of the Act of March second, eighteen hundred and ninety-three, as amended by the Act of April first, eighteen hundred and ninety-six, if such movement is necessary to make such repairs and such repairs can not be made except at such repair point; and such movement Carriers not or hauling of such car shall be at the sole risk of the carrelleved rom
Ilability for rier, and nothing in this section shall be construed to re-
death or injury.

lieve such carrier from liability in any remedial action for the death or injury of any railroad employee caused to such employee by reason of or in connection with the 
movement or hauling of such car with equipment which is defective or insecure or which is not maintained in accordance with the requirements of this Act and the other Acts herein referred to; and nothing in this proviso shall llauling by be construed to permit the hauling of defective cars by means of chains instead of drawbars, in revenue trains or in association with other cars that are commercially used, unless such defective cars contain live stock or "perishable" freight.

SEc. 5. That except that, within the limits specified in $\begin{gathered}\text { Carriers not } \\ \text { relieved from }\end{gathered}$ the preceding section of this Act, the movement of a car penalty, except with defective or insecure equipment may be made with-above named. out incurring the penalty provided by the statutes, but shall in all other respects be unlawful, nothing in this Act shall be held or construed to relieve any common carrier, the Interstate Commerce Commission, or any United States attorney from any of the provisions, powers, duties, liabilities, or requirements of said Act of March second, eighteen hundred and ninety-three, as amended by the Acts of April first, eighteen hundred and ninety-six, and March second, nineteen hundred and three; and, except as aforesaid, all of the provisions, powers, duties, requirements, and liabilities of said Act of March second, eighteen hundred and ninety-three, as amended by the Acts of April first, eighteen hundred and ninety-six, and March second, nineteen hundred and three, shall apply to this Act.

SEc. 6. That it shall be the duty of the Interstate ComEnforcement. merce Commission to enforce the provisions of this Act, and all powers heretofore granted to said Commission are hereby extended to it for the purpose of the enforcement of this Act.

That the jurisdiction of the Interstate Commerce Com- $\begin{gathered}\text { Commission } \\ \text { may extend ef- }\end{gathered}$ mission to extend the period within which any common fective date of carrier shall comply with the provisions of section three Act. of the Act entitled "An Act to supplement 'An Act to promote the safety of employees and travelers upon railroads by compelling common carriers engaged in interstate commerce to equip their cars with automatic couplers and continuous brakes and their locomotives with 4 , $\stackrel{\text { Act of }}{1911}$. March driving-wheel brakes, and for other purposes,' and other safety-appliance acts, and for other purposes," approved April fourteenth, nineteen hundred and ten, shall apply to cars actually placed in service between the date of the passage of said Act and the first day of July, nineteen 
hundred and eleven, in the same manner and to the same extent that it applies to cars actually in service upon the date of the passage of said Act. [36 Stat. L., 1397.]

Public, No. 133, approved April 14, 1910; Public, No. 525, approved March 4, 1911.

Employment Sundry civil act (appropriations) of June 28, 1902,
inspectors. authorizes Commission to employ "inspectors to execute and enforce the requirements of the safety-appliance act."

\section{ACCIDENT REPORTS ACT.}

AN ACT Requiring common carriers engaged in interstate and foreign commerce to make full reports of all accidents to the Interstate Commerce Commission, and authorizing investigations thereof by said Commission.

Be it enacted by the Senate and House of Representatives of the United States of America in Congress assembled, That it shall be the duty of the general manager, superintendent, or other proper officer of every common carrier engaged in interstate or foreign commerce by railroad to make to the Interstate Commerce Commission, at Monthly re-its office in Washington, District of Columbia, a monthly
orts of railway a ccldents. report, under oath, of all collisions, derailments, or other accidents resulting in injury to persons, equipment, or roadbed arising from the operation of such railroad under such rules and regulations as may be prescribed by the said Commission, which report shall state the nature and causes thereof and the circumstances connected therewith: Provided, That hereafter all said carriers shall be relieved from the duty of reporting accidents in their annual financial and operating reports made to the Commission.

Fa il ure to SEC. 2. That any common carrier failing to make such within thirty report within thirty days after the end of any month days after end shall be deemed guilty of a misdemeanor, and upon cona misdemeanor. viction thereof by a court of competent jurisdiction shall

Penalty. be punished by a fine of not more than one hundred dollars for each and every offense and for every day during which it shall fail to make such report after the time herein specified for making the same.

Power of the SEc. 3. That the Interstate Commerce Commission Commission to
inestlgate ac-shall have authority to investigate all collisions, derail-
cidents.

ments, or other accidents resulting in serious injury to 
person or to the property of a railroad occurring on the line of any common carrier engaged in interstate or foreign commerce by railroad. The Commission, or any impartial investigator thereunto authorized by said Commission, shall have authority to investigate such collisions, derailments, or other accidents aforesaid, and all the attending facts, conditions, and circumstances, and for that purpose may subpœna witnesses, administer oaths, take testimony, and require the procluction of books, papers, orders, memoranda, exhibits, and other evidence, and shall be provided by said carriers with all reasonable facilities: Provided, That when such accident is investigated by a commission of the State in which it missions. occurred, the Interstate Commerce Commission shall, if convenient, make any investigation it may have previously determined upon, at the same time as, and in connection with, the state commission investigation. Said Commission shall, when it deems it to the public interlieports of in. est, make reports of such investigations, stating the cause of accident, together with such recommendations as it deems proper. Such reports shall be made public in such manner as the Commission deems proper.

SEc. 4. That neither said report nor any report of said to Reports not investigation nor any part thereof shall be admitted as damage suits. evidence or used for any purpose in any suit or action for damages growing out of any matter mentioned in said report or investigation.

SEc. 5. That the Interstate Commerce Commission is Form of reauthorized to prescribe for such common carriers a method and form for making the reports hereinbefore provided.

SEc. 6. That the Act entitled "An Act requiring com- R e peal of mon carriers engaged in interstate commerce to make full ${ }^{\text {prlor }}$ Act. reports of all accidents to the Interstate Commerce Commission," approved March third, nineteen hundred and one, is hereby repealed.

SEc. 7. That the term "interstate commerce," as used "Inters tate in this Act, shall include transportation from any State "fomerce" and in this Act, shall include transportation from any State "foreign, com-
or Territory or the District of Columbia to any other fined.

State or Territory or the District of Columbia, and the term "foreign commerce," as used in this Act, shall include transportation from any State or Territory or the District of Columbia to any foreign country and from any foreign country to any State or Territory or the District of Columbia. 
When Act effective.

SEc. 8. That this Act shall take effect sixty days after its passage.

Public, No. 165, approved May 6, 1910.

\section{MEDALS OF HONOR ACT.}

AN ACT To promote the security of travel upon railroads engaged in interstate commerce, and to encourage the saving of life.

Be it enacted by the Senate and House of Representatives of the United. Stutes of America in Congress assemLife-saving 1,led, That the President of the United States be, and on railroads. bonor for. medals of honor, with suitable emblematic devices, which shall be bestowed upon any persons who shall hereafter, by extreme daring, endanger their own lives in saving, or endeavoring to sare, lives from any wreck, disaster, or grave accident, or in preventing or endeavoring to prevent such wreck, disaster, or grave accident, upon any railroad within the United States engaged in interstate Proviso. commerce: Provided, That no award of said medal shall Proof. be made to any person until sufficient evidence of his deserving shall have been furnished and placed on file, under such regulations as may be prescribed by the President of the United States.

SEC. 2. That the President of the United States be, and he is hereby, authorized to issue to any person to whom a Rosettes and medal of honor may be awarded under the provisions of ribbons.

this Act a rosette or knot, to be worn in lieu of the medal, and a ribbon to be worn with the medal; said rosette or knot and ribbon to be each of a pattern to be prescribed

Proviso. by the President of the United States: Provided, That

lssue of new
whenever a ribbon issued under the provisions of this Act shall have been lost, destroyed, or rendered unfit for use without fault or neglect on the part of the person to whom it was issued, a new ribbon shall be issued to such person without charge therefor.

Payment of SEC. 3. That the appropriations for the enforcement expenses. and execution of the provisions of the Acts to promote the safety of employees and travelers upon railroads are hereby made available for carrying out the provisions of this Act.

Public, No. 98, approved February 23, 1905. 
REGULATIONS Governing the award of life-saving medals under the foregoing Act. Made by the President of the United States on March 29, 1905, and amended April 22, 1913.

1. Applications for medals under this Act should be Applications addressed to and filed with the Interstate Commerce made. Commission, at the city of Washington, D. C. Satisfactory evidence of the facts upon which the application is based must be filed in each case. This evidence should be in the form of affidavits made by eyewitnesses, of good repute and standing, testifying of their own knowledge. The opinion of witnesses that the person for whom an award is sought acted with extreme daring and endangered his life is not sufficient, but the affidavits must set forth the facts in detail; and show clearly in what manner and to what extent life was endangered and extreme daring exhibited. The railroad upon which the incident occurred, the date, time of day, condition of the weather, the names of all persons present when practicable, and other pertinent circumstances should be stated. The affidavits should be made before an officer duly authorized to administer oaths and be accompanied by the certificate of some United States official of the district in which-the affiants reside, such as a judge or clerk of United States court, district attorney, or postmaster, to the effect that the affiants are reputable and creditable persons. If the affidavits are taken before an officer without an official seal, his official character must be certified by the proper officer of a court of record under the seal thereof.

2. Applications for medals, together with all affidavits committee to and other evidence received in connection therewith, shall be referred to a committee of three persons, consisting of the secretary of the Commission, the chief inspector of safety appliances, and the assistant chief inspector of safety appliances. This committee shall carefully consider each application presented, and after thoroughly weighing the evidence, shall prepare an abstract or brief covering the case, and file the same, together with the committee's recommendation, with the Commission, which brief and recommendation shall be transmitted by the $\begin{gathered}\text { Brief of com- } \\ \text { mittee. }\end{gathered}$ Commission to the President for his approval. The committee may, with the approval of the Commission, direct any inspector in the employ of the Commission to pro- 
Personal in- ceed to the locality where the service was performed for
estigations. which a medal is claimed, and make a personal investigation and report upon the facts of the case, which report shall be filed and made a part of the evidence considered by the committee.

President's a p proval of recom me nda-
tion.

Designs for

3. Upon final approval of the committee's recommendation by the President the Commission shall take such measures to carry the recommendation into effect as the President may direct. medals.

4. The Commission shall cause designs to be prepared for the medal, rosette, and ribbon provided for by the Act, which designs shall be submitted to the President for his approval.

\section{HOURS OF SERVICE ACT.}

AN AC'T To promote the safety of employees and travelers upon railroads by limiting the hours of service of employees thereon.

Be it enacted by the Senate and House of Representacommon cartives of the United States of America in Congress assemployees subject to Act.

bled, That the provisions of this Act shall apply to any common carrier or carriers, their officers, agents, and employees, engaged in the transportation of passengers or property by railroad in the District of Columbia or any Territory of the United States, or from one State or Territory of the United States or the District of Columbia to any other State or Territory of the United States or the District of Columbia, or from any place in the United States to an adjacent foreign country, or from any place in the United States through a foreign country M eaning of to any other place in the United States. The term "railroad." " $\mathrm{ra11-}$ road" as used in this Act shall include all bridges and ferries used or operated in connection with any railroad, and also all the road in use by any common carrier operating a railroad, whether owned or operated under a Meaning of contract, agreement, or lease; and the term "employees" term." "employ- as used in this Act shall be held to mean persons actually engaged in or connected with the movement of any train.

Sixteen hours Sec. 2. That it shall be unlawful for any common car-
he maximum t he maximum continu ous
service of trainmen. rier, its officers or agents, subject to this Act to require or permit any employee subject to this Act to be or remain on duty for a longer period than sixteen consecutive hours, and whenever any such employee of such common carrier shall have been continuously on duty for sixteen hours he shall be relieved and not required or permitted 
again to go on duty until he has had at least ten consecu- Ten consecutive hours off duty; and no such employee who has been duty.

on duty sixteen hours in the aggregate in any twentyfour-hour period shall be required or permitted to continue or again go on duty without having had at least eight consecutive hours off duty: Provided, That no op- Servlce hours erator, train dispatcher, or other employee who by the and telephone use of the telegraph or telephone dispatches, reports, transmits, receives, or delivers orders pertaining to or affecting train movements shall be required or permitted to be or remain on duty for a longer period than nine bours in any twenty-four-hour period in all towers, offices, places, and stations continuously operated night. and day, nor for a longer period than thirteen hours in all towers, offices, places, and stations operated only during the daytime, except in case of emergency, when the employees named in this proviso may be permitted to be and remain on duty for four additional hours in a twentyfour-hour period on not exceeding three days in any week: Provided further, The Interstate Commerce Commiche may extend for good cause shown extend the period within which a common carrier shall comply with the provisions of this proviso as to such case.

SEC. 3. That any such common carrier, or any officer violation. or agent thereof, requiring or permitting any employee to go, be, or remain on duty in violation of the second section hereof, shall be liable to a penalty of not to exceed five hundred dollars for each and every violation, to be recovered in a suit or suits to be brought by the United States district attorney in the district court of the United States having jurisdiction in the locality where such violation shall have been committed; and it shall be the duty of such district attorney to bring such suits upon satisfactory information being lodged with him; but no such suit shall be brought after the expiration of one year from the date of such violation; and it shall also be the duty of the Interstate Commerce Commission to lodge with the proper district attorneys information of any such violations as may come to its knowledge. In all prosecutions under this Act the common carrier shall be deemed to have had knowledge of all acts of all its officers and agents: Provided, That the provisions of this Act shall not apply in any case of casualty or unavoidable accident accidents, etc. or the act of God; nor where the delay was the result of 
a cause not known to the carrier or its officer or agent in charge of such employee at the time said employee left a terminal, and which could not have been foreseen: ProWrecking, vided further, That the provisions of this Act shall not Enforcement. apply to the crews of wrecking or relief trains.

SEc. 4. It shall be the duty of the Interstate Commerce Commission to execute and enforce the provisions of this Act, and all powers granted to the Interstate Commerce Commission are hereby extended to it in the execution of this Act.

Effective. SEC. 5. That this Act shall take effect and be in force one year after its passage.

Public, No. 274, approved March 4, 1907, 11.50 a. m.

\section{ASH-PAN ACT.}

AN ACT To promote the safety of employees on railroads.

$B e$ it enacted by the Senate and House of Representatives of the United States of America in Congress assem$\mathrm{Ash}-\mathrm{p}$ a $\mathrm{n}$ bled, That on and after the first day of January, nineteen equipment in
commerce. carrier engaged in interstate or foreign commerce by railroad to use any locomotive in moving interstate or foreign traffic, not equipped with an ash pan, which can be dumped or emptied and cleaned without the necessity of any employee going under such locomotive.

$\underset{\text { A s h }-p a n}{\text { a }}$ SEc. 2. That on and after the first day of January, Territories and nineteen hundred and ten, it shall be unlawful for any Dismbia.
lomber
common carrier by railroad in any Territory of the United States or the District of Columbia to use any locomotive not equipped with an ash pan, which can be dumped or emptied and cleaned without the necessity of any employee going under such locomotive.

Penalties. SEc. 3. That any such common carrier using any locomotive in violation of any of the provisions of this Act shall be liable to a penalty of two hundred dollars for each and every such violation, to be recovered in a suit or suits to be brought by the United States district attorney in the district court of the United States having jurisdiction in the locality where such violation shall have been Enforcement.committed; and it shall be the duty of such district attorney to bring such suits upon duly verified information being lodged with him of such violation having 
occurred; and it shall also be the duty of the Interstate to Commission Commerce Commission to lodge with the proper district mation. attorneys information of any such violations as may come to its knowledge.

Sec. 4. That it shall be the duty of the Interstate Com- Powers grantmerce Commission to enforce the provisions of this Act, ston. and all powers heretofore granted to said Commission are hereby extended to it for the purpose of the enforcement of this Act.

SEc. 5. That the term "common carrier" as used in $\begin{gathered}\text { Receivers in- } \\ \text { cluded. }\end{gathered}$ this Act shall include the receiver or receivers or other persons or corporations charged with the duty of the management and operation of the business of a common carrier.

SEc. 6. That nothing in this Act contained shall apply whe a ash to any locomotive upon which, by reason of the use of essary. oil, electricity, or other such agency, an ash pan is not necessary.

Public, No. 165, approved May 30, 1908.

\section{TRANSPORTATION OF EXPLOSIVES ACT.}

AN ACT To promote the safe transportation in interstate commerce of explosives and other dangerous articles. and to provide penalties for its violation.

By an Act entitled "An Act to codify, revise, and amend the penal laws of the United States," approved March 4, 1909, to take effect and be in force on and after the first day of January, 1910, the Act entitled "An Act to promote the safe transportation in interstate commerce of explosives and other dangerous articles, and to provide penalties for its violation," approved May 30, 1908, is repealed, and the following sections of said Act to codify, revise, and amend the penal laws of the United States are substituted therefor:

SEc. 232. It shall be unlawful to transport, carry, or D y na mite, convey, any dynamite, gunpowder, or other explosives, carried on pasbetween a place in a foreign country and a place within or for hire. subject to the jurisdiction of the United States, or between a place in any State, Territory, or District of the United States, or place noncontiguous to but subject to the jurisdiction thereof, and a place in any other State, Territory, or District of the United States, or place noncontiguous to but subject to the jurisdiction thereof, on any vessel or vehicle of any description operated by a 
common carrier, which vessel or vehicle is carrying passengers for hire: Provided, That it shall be lawful to transport on any such vessel or rehicle small arms ammunition in any quantity, and such fuses, torpedoes, rockets, or other signal derices, as may be essential to promote safety in operation, and properly packed and marked samples of explosives for laboratory examination, not exceeding a net weight of one-half pound each, and not exceeding twenty samples at one time in a single vessel or vehicle: but such samples shall not be carried in that part of a ressel or vehicle which is intended for the transportation of passengers for hire: Provided further, That nothing in this section shall be construed to prevent the transportation of military or naval forces with their accompanying munitions of war on passenger equipment ressels or vehicles.

Interstate C. o $\mathrm{mmerce}$ Commission to $m$ a $\mathrm{k}$ e regulations for trans portation of ex. plosives.

Liquid nitrog I $y$ cerin, etc. not to be carried on certain vehicles.

SEC. 233. The Interstate Commerce Commission shall formulate regulations for the safe transportation of explosives, which shall be binding upon all common carriers engaged in interstate or foreign commerce which transport explosives by land. Said Commission, of its own motion, or upon application made by any interested party, may make changes or modifications in such regulations, made desirable by new information or altered conditions. Such regulations shall be in accord with the best known practicable means for securing safety in transit, covering the packing, marking, loading, handling while in transit, and the precautions necessary to determine whether the material when offered is in proper condition to transport. Such regulations, as well as all changes or modifications thereof, shall take effect ninety days after their formulation and publication by said Commission and shall be in effect until reversed, set aside, or modified.

SEC. 234. It shall be unlawful to transport, carry, or convey, liquid nitroglycerin, fulminate in bulk in dry condition, or other like explosive, between a place in a foreign country and a place within or subject to the jurisdiction of the United States, or between a place in one State, Territory, or District of the United States, or a place noncontiguous to but subject to the jurisdiction thereof, and a place in any other State, Territory, or District of the United States, or place noncontiguous to but subject to the jurisdiction thereof, on any vessel or vehicle of any description operated by a common carrier in 
the transportation of passengers or articles of commerce by land or water.

SEC. 235. Every package containing explosives or other $\begin{gathered}\text { M a r king of } \\ \text { uackages of ex- }\end{gathered}$ dangerous articles when presented to a common carrice plosives; de.for shipment shall have plainly marked on the outside ing. thereof the contents thereof; and it shall be unlawful for any person to deliver, or cause to be delivered, to any common carrier engaged in interstate or foreign commerce by land or water, for interstate or foreign transportation, or to carry upon any vessel or vehicle engaged in interstate or foreign transportation, any explosive, or other dangerous article, under any false or deceptive marking, description, invoice, shipping order, or other declaration, or without informing the agent of such carrier of the true character thereof, at or before the time such delivery or carriage is made. Whoever shall knowingly violate, or cause to be violated, any provision of this section, or of the three sections last preceding, or any regulation made by the Interstate Commerce Commission in pursuance thereof, shall be fined not more than two thousand dollars, or imprisoned not more than eighteen months, or both.

SEc. 236. When the death or bodily injury of any per- Death or bodson is caused by the explosion of any article named in caused by such the four sections last preceding, while the same is being transportation. placed upon any vessel or vehicle to be transported in violation thereof, or while the same is being so transported, or while the same is being removed from such vessel or vehicle, the person knowingly placing, or aiding or permitting the placing, of such articles upon any such vessel or vehicle, to be so transported, shall be imprisoned not more than ten years.

Public, No. 350, approved March 4, 1909.

\section{BOILER INSPECTION ACT.}

AN ACT To promote the safety of employees and travelers upon railroads by compelling common carriers engaged in interstate commerce to equip their locomotives with safe and suitable boilers and appurtenances thereto.

$B e$ it enacted by the Senate and House of Representatives of the United States of America in Congress assembled, That the provisions of this Act shall apply to any Locomotive common carrier or carriers, their officers, agents, and coilers. employees, engaged in the transportation of passengers or $\begin{gathered}\mathrm{ri} \text { e } \mathrm{rs} \\ \text { act. }\end{gathered}$ 
property by railroad in the District of Columbia, or in any Territory of the United States, or from one State or Territory of the United States or the District of Columbia to any other State or Territory of the United States or the District of Columbia, or from any place in the United States to an adjacent foreign country, or from Meaning of any place in the United States through a foreign country terms. road" as used in this Act shall include all the roads in use by any common carrier operating a railroad, whether owned or operated under a contract, agreement, or lease, "Empioyees." and the term "employees" as used in this Act shall be held to mean persons actually engaged in or connected with the movement of any train.

Locomotives. SEc. 2. That from and after the first day of July, nine$\mathrm{Us}$ e, unless
with safe boil- teen hundred and eleren, it shall be unlawful for any ers, unlawful. common carrier, its officers or agents, subject to this Act to use any locomotive engine propelled by stean power in moving interstate or foreign traffic unless the boiler of said locomotive and appurtenances thereof are in proper condition and safe to operate in the service to which the same is put, that the same may be employed in the active service of such carrier in moving traffic without unnecessary peril to life or limb, and all boilers shall

Inspection. be inspected from time to time in accordance with the provisions of this Act, and be able to withstand such test or tests as may be prescribed in the rules and regulations hereinafter provided for.

Chief and $t w o$
ssistant chief SEc. 3. That there shall be appointed by the President, inspectors. ment, etc. inspector and two assistant chief inspectors of locomotive boilers, who shall have general superintendence of the inspectors hereinafter provided for, direct them in the duties hereby imposed upon them, and see that the requirements of this Act and the rules, regulations, and instructions made or given hereunder are observed by common carriers subject hereto. The said chief inspec-

selection. tor and his two assistants shall be selected with reference to their practical knowledge of the construction and repairing of boilers, and to their fitness and ability to systematize and carry into effect the provisions hereof relating to the inspection and maintenance of locomotive salaries, etc. boilers. The chief inspector shall receive a salary of four thousand dollars per year and the assistant chief inspectors shall each receive a salary of three thousand dollars 
per year; and each of the three shall be paid his traveling expenses incurred in the performance of his duties. The office of the chief inspector shall be in Washington, District of Columbia, and the Interstate Commerce Commission shall provide such stenographic and clerical help as the business of the offices of the chief inspector and his said assistants may require.

SEc. 4. That immediately after his appointment and Inspection qualification the chief inspector shall divide the territory comprising the several States, the Territories of New Mexico and Arizona, and the District of Coltmbia into fifty locomotive boiler-inspection districts, so arranged that the service of the inspector appointed for each district shall be most effective, and so that the work required of each inspector shall be substantially the same. Thereupon there shall be appointed by the Interstate Commerce Commission fifty inspectors of locomotive District in. boilers. Said inspectors shall be in the classified service nn ciassified and shall be appointed after competitive examination according to the law and the rules of the Civil Service Commission governing the classified service. The chief inspector shall assign one inspector so appointed to each of the districts hereinbefore named. Each inspector shall receive a salary of one thousand eight hundred dollars Saiaries, etc. per year and his traveling expenses while engaged in the performance of his duty. He shall receive in addition thereto an annual allowance for office rent, stationery, and clerical assistance, to be fixed by the Interstate Commerce Commission, but not to exceed in the case of any district inspector six hundred dollars per year. In order to obtain the most competent inspectors possible, it shall of aminations be the duty of the chief inspector to prepare a list of questions to be propounded to applicants with respect to construction, repair, operation, testing, and inspection of locomotive boilers, and their practical experience in such work, which list, being approved by the Interstate Commerce Commission, shall be used by the Civil Service Commission as a part of its examination. No person in- tions terested, either directly or indirectly, in any patented article required to be used on any locomotive under supervision or who is intemperate in his habits shall be eligible to hold the office of either chief inspector or assistant or district inspector.

SEc. 5. That each carrier subject to this Act shall file Inspection by its rules and instructions for the inspection of locomotive $66170^{\circ}-14-7$ 
boilers with the chief inspector within three months after the approval of this Act, and after hearing and approval Approval, by the Interstate Commerce Commission, such rules and filed. $\mathrm{rules}$ instructions, with such modifications as the Commission requires, shall become obligatory upon such carrier: ProProvisos. vided, however, That if any carrier subject to this Act
Rules to be observed if shall fail to file its rules and instructions the chief into file any. spector shall prepare rules and instructions not inconsistent herewith for the inspection of locomotive boilers, to be observed by such carrier; which rules and instructions, being approved by the Interstate Commerce Commission. and a copy thereof being served upon the president, general manager, or general superintendent of such carrier, shall be obligatory, and a violation thereof punchanges. ished as hereinafter provided: Provided also, That such common carrier may from time to time change the rules and regulations herein provided for, but such change shall not take effect and the new rules and regulations be in force until the same shall have been filed with and apofice rules, proved by the Interstate Commerce Commission. The chief inspector shall also make all needful rules, regulations, and instructions not inconsistent herewith for the conduct of his office and for the government of the disApproval of trict inspectors: Provided, however, That all such rules and instructions shall be approved by the Interstate Commerce Commission before they take effect.

District in- SEC. 6. That it shall be the duty of each inspector to spection.

become familiar, so far as practicable, with the condition of each locomotive boiler ordinarily housed or repaired in his district, and if any locomotive is ordinarily housed or repaired in two or more districts, then the chief inspector or an assistant shall make such division between inspectors as will avoid the necessity for duplication of Personal in-work. Each inspector shall make such personal inspecboilers. tion of the locomotive boilers under his care from time to time as may be necessary to fully carry out the provisions of this Act, and as may be consistent with his other duties, but he shall not be required to make such inspections at stated times or at regular intervals. His first duty shall Incpection by be to see that the carriers make inspections in accordance
carriers. with the rules and regulations established or approved by the Interstate Commerce Commission, and that carriers repair the defects which such inspections disclose before the boiler or boilers or appurtenances pertaining thereto are again put in service. To this end each carrier sub- 
ject to this Act shall file with the inspector in charge, under the oath of the proper officer or employee, a duplicate of the report of each inspection required by such filed. rules and regulations, and shall also file with such inspector, under the oath of the proper officer or employee, a report showing the repair of the defects disclosed by the Repairing de. inspection. The rules and regulations hereinbefore provided for shall prescribe the time at which such reports shall be made. Whenever any district inspector shall, in Notice of dethe performance of his duty, find any locomotive boiler etc. or apparatus pertaining thereto not conforming to the requirements of the law or the rules and regulations established and approved as hereinbefore stated, he shall notify the carrier in writing that the locomotive is not in serviceable condition, and thereafter such boiler shall not be used until in serviceable condition: Provided, That a

carrier, when notified by an inspector in writing that a chief inspector locomotive boiler is not in serviceable condition because of defects set out and described in said notice, may, within five days after receiving said notice, appeal to the chief inspector by telegraph or by letter to have said boiler reexamined, and upon receipt of the appeal from the inspector's decision the chief inspector shall assign one of the assistant chief inspectors or any district inspector other than the one from whose decision the appeal is taken to reexamine and inspect said boiler within fifteen days from date of notice. If upon such reexamination Effect. the boiler is found in serviceable condition, the chief inspector shall immediately notify the carrier in writing, whereupon such boiler may be put into service without further delay; but if the reexamination of said boiler sustains the decision of the district inspector, the chief inspector shall at once notify the carrier owning or operating such locomotive that the appeal from the decision of the inspector is dismissed, and upon the receipt of such notice the carrier may, within thirty days, appeal to the Appeals to

Interstate Commerce Commission, and upon such appeal, $\begin{gathered}\mathrm{Comm} \text { o r } \mathrm{c} \text { e } \mathrm{e} \\ \text { Commission. }\end{gathered}$ and after hearing, said Commission shall have power to revise, modify, or set aside such action of the chief in-

Final action. spector and declare that said locomotive is in serviceable condition and authorize the same to be operated: Provided further, That pending either appeal the requirements of the inspector shall be effective.

Reexamination.

Effect.

SEc. 7. That the chief inspector shall make an annual report to the Interstate Commerce Commission of the port of chector.

Inspector"s requirements effective pending appeals. Annual re. 
work done during the year, and shall make such recommendations for the betterment of the service as he may desire.

Accidents SEC. 8. That in the case of acciclent resulting from failrrom failure of
boliers. nances, resulting in serious injury or death to one or more persons, a statement forthwith must be made in writing of the fact of such accident, by the carrier owning or opInvestigation. erating said locomotive, to the chief inspector; whereupon the facts concerning such accident shall be investigated by the chief inspector or one of his assistants, or such inspector as the chief inspector may designate for Disabled that purpose. And where the locomotive is disabled to parts to be pre-
served. part or parts affected by the said accident shall be preserved by said carrier intact, so far as possible, without hindrance or interference to traffic until after said in-

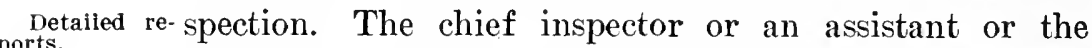
designated inspector making the investigation shall examine or cause to be examined thoroughly the boiler or part affected, making full and detailed report of the cause of the accident to the chief inspector.

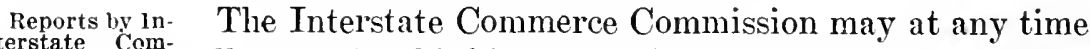
terstate Com-
merce Commis- call upon the chief inspector for a report of any accident sion of cause, embraced in this section, and upon the receipt of said re-
etc. port, if it deems it to the public interest, make reports of such investigations, stating the cause of accident, together with such recommendations as it deems proper. Such reports shall be made public in such manner as the CommisReports, etc., sion deems proper. Neither said report nor any report of not admitted in
damage suits. as evidence or used for any purpose in any suit or action for damages growing out of any matter mentioned in said report or investigation.

Penalty for SEc. 9. That any common carrier violating this Act or violations b carriers.

any rule or regulation made under its provisions or any lawful order of any inspector shall be liable to a penalty of one hundred dollars for each and every such violation, to be recovered in a suit or suits to be brought by the United States attorney in the district court of the United Duty of dis- States having jurisdiction in the locality where such viotrict attorness
to bring suits. lation shall have been committed; and it shall be the duty of. such attorneys, subject to the direction of the Attorney General, to bring such suits upon duly verified informa- 
tion being lodged with them, respectively, of such violations having occurred; and it shall be the duty of the Information chief inspector of locomotive boilers to give information spector. to the proper United States attorney of all violations of this Act coming to his knowledge.

SEC. 10. That the total amounts directly appropriated Limit of apto carry out the provisions of this Act shall not exceed for any one fiscal year the sum of three hundred thousand dollars.

Public, No. 383, approved February 17, 1911.

\section{BLOCK SIGNAL RESOLUTION.}

JOINT RESOLUTION Directing the Interstate Commerce Commission to investigate and report on block-signal systems and appliances for the automatic control of railway trains.

Resolved by the Senate and House of Representatives of the United States of America in Congress assembled, That the Interstate Commerce Commission be, and it is hereby, directed to investigate and report on the use of vestigate a nd and necessity for block-signal systems and appliances for cess 1 ty for the automatic control of railway trains in the United States. For this purpose the Commission is authorized to employ persons who are familiar with the subject, and may use such of its own employees as are necessary to make a thorough examination into the matter.

In transmitting its report to the Congress the Commis- Commission sion shall recommend such legislation as to the Commis- mony and make sion seems advisable. tions.

To carry out and give effect to the provisions of this resolution the Commission shall have power to issue subpœnas, administer oaths, examine witnesses, require the production of books and papers, and receive depositions taken before any proper officer in any State or Territory of the United States.

Public Resolution, No. 46, approved June 30, 1906.

Urgent deficiency act (appropriations) of October 22, Block signai 1913 , provides that the Interstate Commerce Commission, at its discretion, may investigate and report in regard to the use and necessity for block-signal systems and appliances for the automatic control of railway trains and any appliances or systems intended to promote the safety of railway operation, including experimental tests of 
such systems and appliances as shall be furnished in completed shape, to such Commission for such investigation and test, free of cost to the Government, in accordance with the provisions of the joint resolution approved June thirtieth, nineteen hundred and six.

*

*

*

$*$

$\%$

No money appropriated by this or any other Act shall be used for the compensation of any publicity expert unless specifically appropriated for that purpose. 


\section{INDEX.}

Absorption, noncompetitive short lines by main linese.

Access, Commission's agents to carrier's' property

Accidents :

Excepted from hours-of-service act

From defective boilers__._._. 100

Accidents report act_________ 86-88

Damage suits, reports not to be used in

Failure to report_._._. 86

Foreign commerce defined___...... 87

Form of report........... 87

Interstate commerce defined $\quad 87$

Monthly reports of accidents._. 86

Penalty for failure to report

Power of Commission to investigate accidents____._. 86

Repeal of prior act_................ 87

Report of investigations_________ 87

State commissions, cooperation with

Testimony

Accounts of carriers:

Access to-

Commission shall have

Commission's agents shall have

Destruction of, Commission may permit

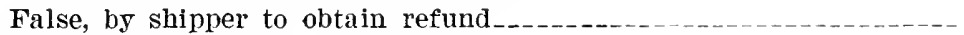

Filing of, mandamus to compel

Form of, Commission may prescribe

Uniform system of, Commission may prescribe

Act of God excepted, hours-of-service act_....... 91

Action for damages :

Complaint to Commission or suit in court

Enforcement of Commission's award of damages_................. 33

Government-aided lines_........ 76

Adjacent foreign country. transportation to and from

Advance in rates:

Burden of carrier to justify

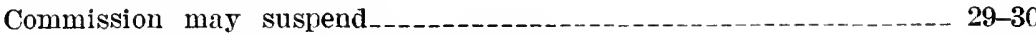

Due to elimination of water competition 13

Advantage, unreasonable, unlawful__. 12

Affidavits :

False by shipper to obtain refund, etc

Medals of honor act_..._-_._- 89

Affirmations, Commissioners may administer._......... 36

Agents, necessary, free transportation_............. 9,46 
Agents of carrier:

Page.

Acts of, are deemed to be acts of carrier........ 57

Deemed to know acts of

Name of, to be posted at stations._...

Passes to__._._._._._._._. 96

Service on carrier by leaving coly with_._._. 49

Washington agents-

Service of order of Commission on

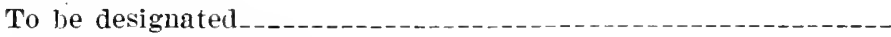

A gents of Commission, special :

"To inspect accounts, Commission mity employ

Tw receire evidence. Commission may employ

Agreement :

Annual report of cirrier concerning

Commission mas require production of

Conditioned upon purchaser not to deal with competitor

Filed with Commission are public records_._._._....................

For pooling of freights and division of earnings, unlawful_.........

No person excused from producing

Of carriers to be filed with Commission_._.

of Goremment-aided lines, to be filed with Commission..........-..-

Road operated under. included in term " railroad ".................

To break bulk, unlawful if to prevent continnous carriage.

Aid to carriers from United States, etc., value of

Air brakes, percentage of carriers in train

Allowance :

Shipper to obtain by false means, a misdemeanor

To Gorernment made bs carriers in consideration of land grants, etc

To owners of traffic for service rendered

American Railway Association to designate height of drawbars

Ammunition under explosives act_-_...

Analysis of methods of ascertaining costs of property of carriers--.------

Annual reports of carriers:

Commission may require and prescribe method of making

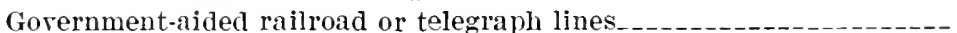

Statistics in, are public records.

To be filed by September 30 of each year

Annual reports, chief inspector of locomotive boilers

Annual reports of Commission:

Commission to Congress

Printed for distribution

Antitrust aets :

Order under Clayton Act does not relieve from

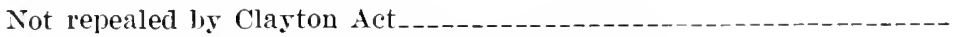

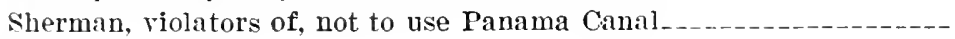

Circuit Court of Appeals to United States Supreme Court under Claston Act.

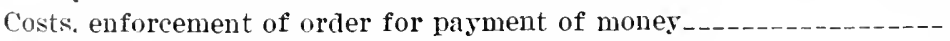

District courts to United States Supreme Court_..._.................

District inspector's decision-

To chief inspector

To Commission. 
Appeals-Continued.

Page.

Inspectors' requirements effective pending

Interested parties may, from enforcement of orders under Clayton

Act

Supreme Court and court of appeals under expediting act

Appearances before Commission, by attorney or in person

Appliances, Commission to designate

Application :

Carriers-

For relief from operation of section 4

To determine question of competition with water lines..........

Medals of honor

Shipper's or lateral branch line's, for switch connection

Appointments by President:

Boiler-inspection act.-

Interstate Commerce Commissioners

Appropriations :

Block-signal resolution

Boiler-inspection act.

Medals of honor act

Arrangement :

Between carriers filed with Commission.

Between carriers filed with Commission, public records

Between rail and water lines for continuous carriage.

Artificlal person, penalty of imprisonment shall not apply to-_-_-_-_-_-

Ash-pan act

Duty of Commission

Enforcement _.........

Equipment necessary

Locomotives excepted._._._.

Penalty for violation

Receivers included._-_-_-_- 93

Association :

Complaint to Commission by

Subsidy or donation from, to carriers.___. 38

Assumption of risk

Attorney General:

Authority to transfer property of Commerce Court

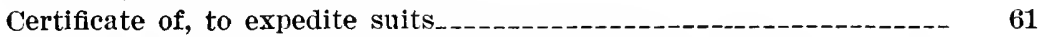

Commission to report to, of violations of making purchases without bids.

District attorneys to prosecute under direction of

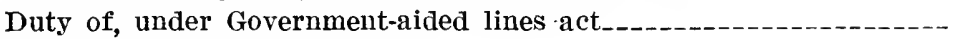

Notice to, of tentative valuation

To direct prosecutions_____.

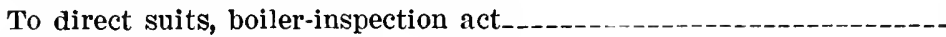
Attorneys: (See also District Attorneys.)

Commission may employ

Parties may appear by, or in person

Passes to attorneys in employ of carrier. Attorney's fees, carrier liable for, as part of costs A utomatic couplers, cars to be equipped with 
Award of damages:

Commission may make

Enforcement of Commission's

Baggage :

Agents, passes to

Free, under mileage tickets.

Personal, sample, and excess

Bank:

Director, officel, or employee in more than one, prohibited

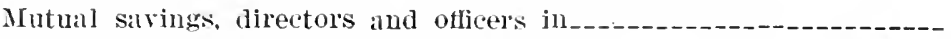

Banker, private, director, etc., in bank organized under United States laws_

Banking arrallgements, for issuance of stocks, ete

Banks. Federal IReserve Board to enforce Clayton det where applicable to Betterments in calrier's property -

Bids:

Contrats, etc. between corporations to be bs competitive.

Penalty for preventing bidding or competition among bidders.

Bill, fillse, by shipper-_._.

Bill of lading:

Carrier shall issue

Exempting carrier from liability

False, by shipper to obtain refund.

Issued for transportation of stores used in valuation service...--.--

Regulations, reasonable, affecting

Billing, false, by shipper or carrier-_......

Block-signal resolution _...............

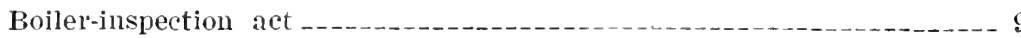

Accidents reported to chief inspector...........

Anuual report of chief inspector.

Appeal to chief inspector and Commission

Appropriation

Boiler's subject to

Carriel's affected

\section{9}

99

101

96

95

Chief inspector

Civil service

Damage suits, reports not to be used in 100

Defective boilers, notice of

Employees defined__._- 96

Enforcement of - 100

Examinations for inspectors._._. 97

Inspection-

By carriers

97,98

Districts, United States divided into__._._._. 97

Inspectors, salary, etc

$96,97,98$

Inrestigation of accidents_._______ 100

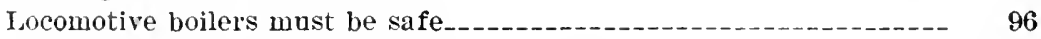

Offices of chief inspector and district inspector.......... 97

Penalty for violation._._._-_._- 100

Rallroads defined _._. 96

Report of accidents

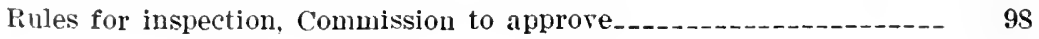


Bond :

Execution of-

Injunction proceedings under Clayton Act_.................

Where temporary restraining order granted under Clayton Act_-

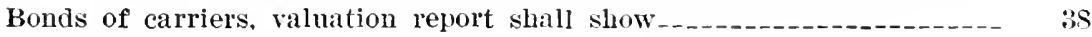

Books and papers:

Commerce Court, sent to Department of Justice._.

Commission may require production of

Courts may compel production of

No person excused from producing

Branch line:

Application of, for switch comnection...._. 11

May be acquired by main lines___._. 64

Breaking bulk, unlawful unless made in good faith_._. 21

Bridges included in term " railroad"

Briefs to President, medals of houor act_._. 89

Bulk, break of

Burden of proof on carrier to justify advances_..... 30

Business, Commissioner's not to have other.

Cable companies:

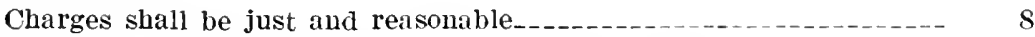

Exchange of passes or franks with common carrier-_..._..... 10

Exchange of service with common carrier.............. 9

Messages, classification__._._._._._. 8

Subject to act

Calamitous visitation, carrying passengers free in cases of 10

Canal :

Lake Erie and Ohio River Ship Canal_...

Panama Canal__._._._._._._._._. 14, 15, 20

Capital stock:

Director, etc., in more than one bank where entire capital stock is owned by the other

Increases or decreases, valuation report shall show__._._._._._. 38

Caretakers of live stock, etc., passes to $\quad$ 9-10

Carmack amendment

Carriers :

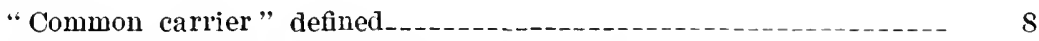

Deemed to have knowlenge of acts of agents, etc

Held to mean common carrier._. 17

Notice to, of tentatire valuation $\quad 40$

Shall file rules and instructions___._._._._. 97,98

Subject to act-_..- 7

Subject to-

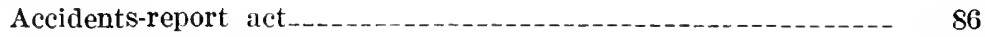

Asb-pan act _... 02

Boiler-inspection act ......... 95

Explosives act _..._. 93

Hours-of-serrice act

Safety-appliance act_...

Cars:

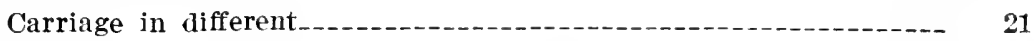

Defective, mav be hauled to nearest repair point_............. 84 
C'ars-Continued.

Page.

Equipped with train brakes, automatic couplers. etc.................

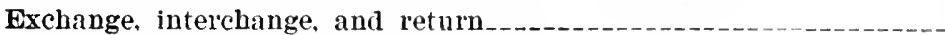

Furnished for shipper with spur track

Included in term "transportation"

Mandamus to compel furnishing

Not equipped with safety appliances, not to be hindled._._.........

Subject to safety-appliance act____.

Certificate, false. by shipper to obtain refund, etc

Certiorari, review by supreme Court of order under Clayton antitrust act

Chains, hauling by, not permitted unless cars contain live stock or per-

isbable freight

Chairman of Commission shall approve rouchers

Changes :

In conditions and ralue of carrier's' property

In rates

Charges :

Commission may prescribe maximum__._._.

Filed with Commission, public records..._.

For services rendered by owner of property transported............

Less for longer than for shorter haul_...

Iust be just and reasonable

Rules and regulations affecting

Terminal and all other, to be printed and posted_____________ 16

Unless filed, carrier not to transport__._._. 17

Charitable:

Institutions, passes to inmates of

Work, passes to persons engaged in__._.

Chief inspector:

Annual report to Commission

Appointed by President

Carriers may appeal to

Notify district attorneys of violations of act

Report of accidents _. 100

Children, minor, of deceased employees of carrier, passes to _._._._._. 10

Circuit court of appeals :

Appeals to, under expediting act

Commission may apply to for enforcement of order under Clayton antitrust act.

Exclusive jurisdiction under Clayton antitrust act Civil service:

District inspectors chosen by

Shall use questions approved by Commission

\section{Claims :}

False, by shipper to obtain refund, etc

'To be filed within two years._._._. 33

Classification :

Commission may prescribe

Copies of. filed with Commission, public records_..._._._._._.

Elements of valuation, Commission may determine_._._._._._._. 39

False-

By carrier, misdemeanor

By shipper, fraud, declared a misdemeanor 
Classification-Continued.

Page.

Must be just and reasonable_..._._.

of property of carriers for valuation

of telegraph and telephone messiges._._._._._._. 8

Printing and posting

Classified service, district inspectors under-_.. 97

Clayton antitrust act

Clerical assistance, boiler-inspection act______ 97

Collisions must be reported and investigated_._. 86

Combination:

For pooling of freights and division of earnings

To break bulk, unlawful, unless in good faith

Commerce:

Federal Trade Commission to enforce compliance with Clayton antitrust act where applicable to other than common carriers and banks

Person engaged in, not to discriminate in prices................ 62 Commerce Court:

Abolished

Books, dockets, etc., sent to Department of Justice

Cases pending in, trinsferred to district courts, exceptions___._._. 53

Cases remanded by Supreme Court to district courts_._._._. 53

Jurisdiction of, transferred to district courts______________ 50

No successors to judges to be appointed__._. 50

Tenure of office of judges not affected... 50

Commercial messages, telegraph, etc......... 8-9 Commissioners:

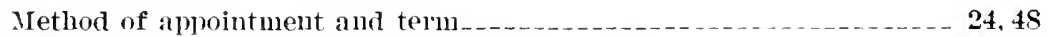

Not more than four from same political party

One or more mas sign subpœna_._. 36

Qualifications of _. 24,46

Salary of

Committee, medals of honor act

Commodities clause _._. 11

Common carriers:

Commission to enforce compliance with Clayton antitrust act where applicable to

Complaints by _......... 27

Defined -

Duty to observe and comply with orders__... 34

Embezzlement by President, etc., of felony

Includes receivers, ash-pan act_... 93

Subject to act

To include express and sleeping-car companies_____________._. 8

Commutation tickets, issuance of, not prohibited_._. 46

Companies, complaints to Commission by 27

Compensation :

Employees transported in valuation service

For short haul as great as or greater than for long haul_........ 12-13

For switch connection, Commission to investigate-_......... 11

Greater or less than published tariffs._. 47

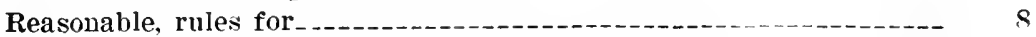

Competent evidence, report and decision of Commission._._._-_._- 28 
Competing line:

Railroad not to have interest in competing water line

Shipper may designate routing.

Competition :

Discrimination in prices so as to lessen

Elimination of, by interlocking directorates

Penalty for preventing, among bidilers

Restraint in. by acquisition of stock of competitor

competition of water line

Conmission to determine question of $\ldots$

Reduced rate to meet__._.

competitor, lease, sale. or contract upun condition not to deal with.

mulawful

$62,6 \%$

Complaints to Commission :

Answer of carrier in writing.

Based on violation of the act.

By whom male

Concuryent remedy with suit in court

Goverument-airled lines, discrimination

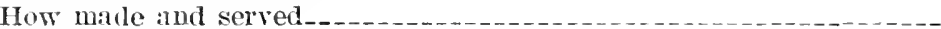

Investigation of _._._.

No dismissal, becanse no direct damage to complainant

Procedure for investigating muler Clayton antitrust act.

Proposed rates

Satisfaction of, bs carlier........

Compliance. time for:

Hours of service act

Safet $\mathrm{-appliance}$ act

Compulsoly-testimony act

Concessions :

By carriers in consideration for grants

39

Unlawîul to gire or receive

conclusions, report shall state

Concurrence in joint tariffs

Condemnation cost of property of carriers.

conflicting laws repealed

49. $54,60.77$

Congress:

Innual report of Commission to

Right to amend or repeal Govermment-ilided railroad acts

Valuation report of Commission to

Connecting lines:

Discrimination between, forbidden

12

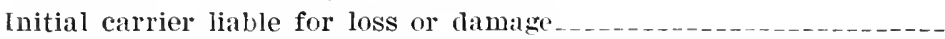

Interchange of traffic between.

Recourse against. by initial line

Refusal of cars from

Use of tracks or terminal facilities of another carrier

Connecting telegraph lines with Government-aided lines_.

Connecting tracks, terms, and conditions of construction

Connivance by shipper with carrier-

Consignee:

False billing by, etc., declared a misdemeanor

Information concerning shipment of, not to be disclosed

Unjust discrimination against, induced by other shipper 
Consignor :

Page.

False billing, etc., declared a nisdemeanor

Unjust discrimination against, induced by other shipper

Construction :

Branch or short lines by main lines. not prohibited.

If part of act held invalid, other parts shall not be affected.

Continuous carriage:

By rail and water lines

Device to prevent, unlawful

Contracts :

And agreement to be filed with Commission

Annual report of carrier conceluing

Carrier probibited from purchasing from another corporation having same officel's.

Commission may require production of

Conditioned upon purchaser not to deal with competitor.-

Exchange of services

Exempting carrier from liability

Filed with Commission are public records

For pooling of freight and division of earnings

For use of cars, facilities, etc

No person excused from producing

Of Gorernment-aided lines to be filed with the Commission ___.

Road operated under, included in term "railroad"

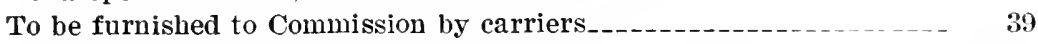

To break bulk, unlawful if to defeat continuous carriage _.. $20-21$

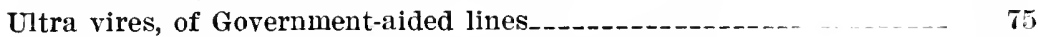

Control of competing water carrier, railroad not to have

Cooperation by carriers in valuation work required _....... 39

Copies of maps, etc., to be furnished to Commission by carriers____ 39

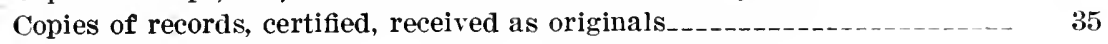

Corporate organization, history of, in valuation report__. 38

Corporations :

Complaints to Conmission by-_... 27

Liable under Elkins Act._._._._._._. 56

Penalty of imprisonment shall not apply to

Same person not to be director in two or more

Subsidy or donation from, to carriers____ 38

Subsidiary formation of, not prohibited__._. 63

Correction of valuation._. 40

Cost, false representation by shippers_____. 23

Cost of carriers' property, original and reproduction $\ldots$

Costs :

And expenses of prosecution

Attorney's fees, collected as part of _..._.

Condemnation of property of carriers._. 38

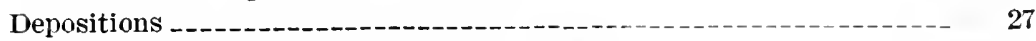

Petitioner not liable for, unless on his appeal _....... 33

Counsel fee, liabllity of carrier.

County, donation from, to carriers 
Couplers :

Act applies where brought together

Cars must be equipped with automatic

Courts. (sce also District courts.)

Conmerce

Commission may apply to, for enforcement of order under Clayton

Antitrust Act

District

Eridence different from Commission's raluation sent to Commission_

Final valuation prima facie evidence

Order for payment of money to be enforced iu

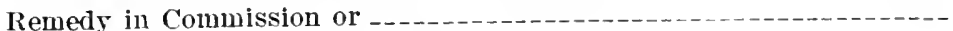

Scope of jurisdiction in prosecutions

Supreme

To compel witnesses to attend and testify

Criminate. that testimony may, no excuse

$21,26,54,59$

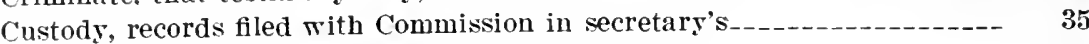

Customs duties, when domestic freight subject to

Customs inspectors, passes to _..._. 9-10

Damages :

Action for, against Government-aided lines

Award of, Commission may make

Bringing a suit for

$21,33,59$

Caused by misstating rate

Caused by shippers inducing carriers to discriminate

Caused by violation of the act.

Complaints for, to be filed within two sears

Complaints not to be dismissed because no direct damage........-..--

Election of remedies_._._._.

Enforcement of award in court

Exemption of carrier from liability

Initial carrier liable on through shipments_

Issuance of temporary restraining order. without notice, against, under Clayton Antitrust Act._.

Joint liability for

Report shall include finding of fact

Suit against person receiving rebate

Suit on award, what petition shall state-_._......... 33

Damage suits :

Boiler-inspection reports not eridence in

Accident reports not evidence in

Data, raluation of Commission, public inspection of

Iehts, funded and floating. annual report of carrier shall show

Decision, equal dirision of court under expediting act....................

Decision of Commission, report in writing

Decisions of Commission to be published and be competent as evidence...-

Dedication to public use of property of carriers, time of

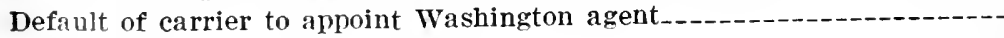

Defective :

Boilers shall not be used

Cars may be hauled to nearest remair point

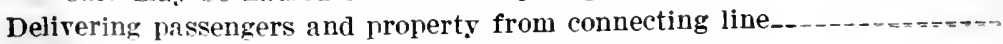


Delivery of property :

Page.

For transportation

Included in term "transportation"

Wholly within one State

Department of Justice, Commerce-Court property transferred to_._-_._- 53

Deposition :

False, by shipper to obtain refund, etc

Fees of officers, etc_.___._. 27

Foreign country _._._. 26

Testimony taken by

Depots, yards, and grounds included with term " railroad"

Depreciation, property of carriers _._- 38

Derailments must be reported_-___-_-_-_- 86

Designation of Washington agent filed in office of secretary _..__._. $\quad 49$

Designs for medals

Destination, defined _._. 51

Destitute per'sons, passes to

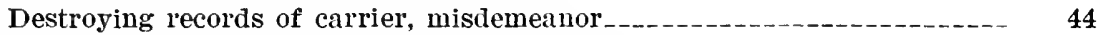

Destruction of records, Commission may permit____________ 45

Device:

By carrier to obtain transportation at less than regular rates_-...--

By carrier to permit transportation at less than regular rates

To collect greater or less compensation, unlawful_._.-......-

To depart from the published tariffs, misdemeanor...........................

To prevent continuous carriage, unlawful_._.

To rebate, forbidden

Different compensation from tariff rate_____ 17

Director :

Bank, eligibility of

Corporation, eligibility of

In more than one bank prohibited...-...-

In more than one bank where entire capital stock is owned by the other.

Private, and bank organized under United States laws...-_._-_.-.

Private bank

Same person not to be in two or more corporations_._............

Disabled employees of carriers, passes to

Disclosing information :

Concerning shipments.

Penalty for examiner.

Discontinuance of discrimination by order of court

Discrimination :

Between connecting lines forbidden

Forbidden by telegraph-line connection with Government-aided line

Lake Erle \& Ohio River Ship Canal not to make-_..-..--.--..--

None by persons engaged in commerce in price of commodities.....-.-

Penalty for inducing.

Unjust by special rate, rebate, drawback, or device._.

Unlawful, fine or imprisonment for

Unlawful to give or receive

$66170^{\circ}-14-8$ 
District attorneys :

Duty under-

Page.

Ash-pan act _.......... 92

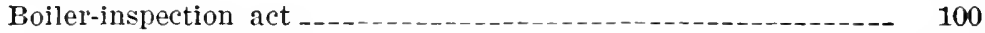

Hours-of-service act _._._._._._. 91

Safety-appliance acts_._._._.

To prosecute for recorery of forfeitures ___

To prosecute under direction of Attornes General_................ 25, 34

District courts :

Appeal from_-_._. 52

Commerce Court jurisdiction and cases transferred to_._____._-_ 50,53

Duties under Elkins Act._. 61

Jurisdiction act_.... 50

Jurisdiction-

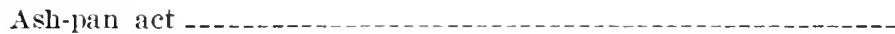

Boiler-inspection act

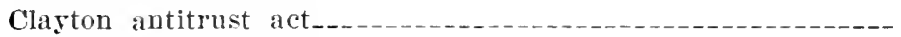

Hours-of-service act_.............

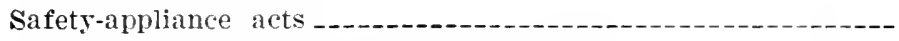

To restrain violation of Clayton antitrust act

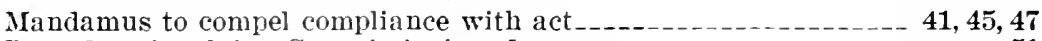

Procedure involving Commission's orders._._._._._........... 51

To compel by mandamus compliance with valuation provisions_._-_- $4 \mathbf{4 1}$

District of Columbia :

Included in-

Ash-pan act

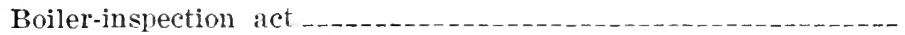

Safetr-appliance acts_._.

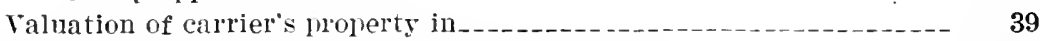

District inspectors, boiler-inspection act, duties, etc_-___________ 97, 98

Districts, United States, divided into, boiler-inspection act-_-__-_-_- 97

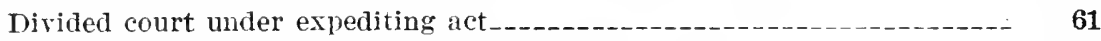

Dividends paid, annual report of carriers shall show

Dirision of earnings and pooling of freights

Division of rates, Commission may prescribe

Dockets, Commerce Court, to Department of Justice

Docks. phrsical comnections with rail carrier

Documentary evidence:

Commission may require production of

Courts may compel production of

No person excused from producing

Penalty for refusing to produce

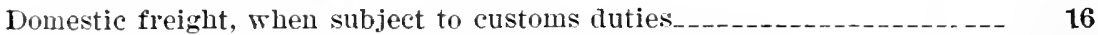

Donation to carriers from the United States, etc., value of

Drawback:

Lake Erie \& Ohio River Ship Canal, not to grant

Cnlawful_______._.

Drawbars :

Commission mas modify height of

Standard height of _._.

Driving-wheel brakes, engines must be equipped with

Duty and power of Commission_-_- 25 
Duty, period of, hours-of-service act._-_._. 90

Dynamite under explosives act-_-_._- 93

Earuing of carriers:

Annual reports of carriers shall show

Division of, and pooling of freights..... 13

Monthly reports of carriers._- 43

Valuation report to show

Effective date of act

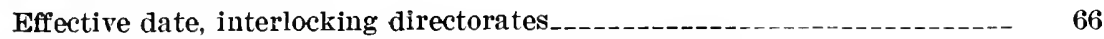

Election of remedies for damages caused by violations_______._. 21

Eleemosynary :

Institutions, passes to inmates of

Work, passes to persons engaged in

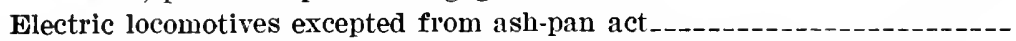
Electric passenger railways, street, through route and joint rate with Elements of valuation

Elevation, included in term "transportation"

Eligibility of director, officer, or employee

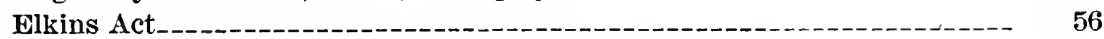

Embezzlement, president, etc., of common carrier, felony

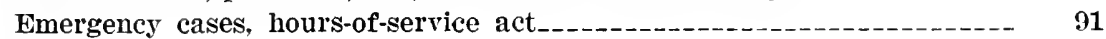

Employee :

Bank, eligibility of

In more than one bank, prohibited_._-_._- 64

In more than one bank where entire capital stock is owned by the other

Private bank, and bank organized under United States laws_...--.-

Employees of carriers :

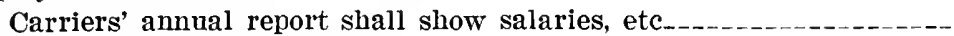

Defined, boiler-inspection act-_-_-_- 96

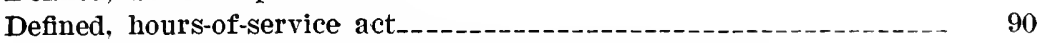

Duty to observe and comply with Commission's orders......... 34 .

Killed in service, pass for remains_._. 10

Passes to

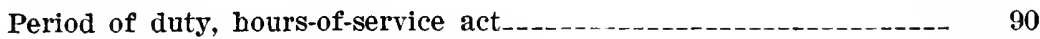

Subject to penalties for violating law

What term "employee" includes_._......... 10

Employees of Commission :

Commission's annual report to show names, etc

Commission may hire and fix compensation of

Commission may hire to investigate block signals

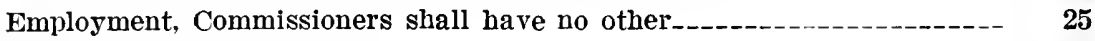

Employment of inspectors :

Boiler-inspection act_....... 96, 97

Safety-appliance acts_._-_._. 86

Enforcement of act-_-_-_-_- 25

Enforcement :

Ash-pan act._.

Boiler-inspection act _._._._. 100

Hours-of-service act-_-_-_-_-_-_- 92

Safety-appliance acts_-_-_-_-_-_-_-_- 85

Entry, false by shipper to obtain refund, etc

Epidemic, carrying passengers free in case of 
Equal facilities:

For interchange of traffic

Telegraph line connecting with Government-aided line

Equipment :

Cost and value, annual report of carrier shall show

Sa fety-appliance acts.

Equity suits under act expedited

Eridence :

Conrt may order Commission or board to hear additional under Clayton antitrust act.

Existing law for production of

Final valuation, prima facie evidence

Findings of fact by Commission, prima facie

Findings of fact under Clayton antitrust act, conclusive__._._._._-_ 69, 70

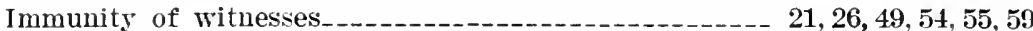

In court as to value different from valuation of Commission._-_ 41

Not to be used as, accident reports__._______ 87

Not to be used as boiler-inspection reports._. 100

Reports and decisions, competent as _._._._._._._. 28

Special agents or examiners may receive....... $3 \mathbf{7}, \mathbf{4 5}$

Examinations, chief inspector to prepare questions...............

Examlners, special:

Commission may employ

Penalty for dirulging information

Testimony taken before

Exceptions :

Ash-pan act

Explosives act

Hours-of-service act

Permitting use of chains, safety-appliance acts_

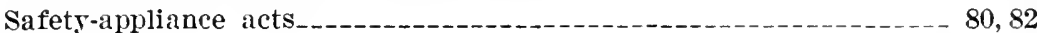

Excess baggage

Exchange of cars

Exchange of service between common carrier and telegraph companies, ete-

Excursion tickets, not prohibited.

Exemployees, entering service of carrier, passes to.

Exempting carrier from liability

Expediting act.

Expediting case, hearing on, temporary restraining order under Clayton antitrust act.

Expediting cases involving increased rates

Expediting cases under Clayton antitrust act

Expenditures of carriers, valuation reports shall show

Expenses :

Monthly report of

of Commission and employees

of prosecution

Operating and other, annual report of carrier shall show

Experts for valuation work, Commission may employ

Explosive act. (See Transportation-of-explosives act.)

Explosives:

Commission to regulate packing. etc

Not to be carried on passenger vehicles 
Export traffic, subject to act

Page.

Exposition, free or reduced rates for

Express cars, employees on, passes to

Express companies, common carriers _.

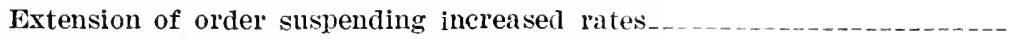

Extensions, raluation of carriers

Facilities :

Equal, Goverument-aided telegraph lines

For interchange of traffic

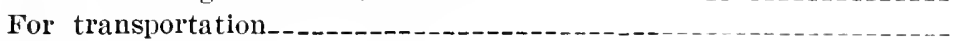

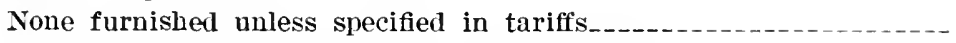

Of shipment included in term "transportation"

To be specified in schedules_._._._._._._._. 15-16

Fairs, free or reduced rates for.-_- 46

False :

Billing, etc., by carrier or shipper._- 22-23

Entry in accounts_._._._. 44

Families of carrier's employees:

Passes to

What included in term "families" 10 Fares :

Annual report of carrier concerning --

Maximum, Commission may prescribe

Must be just and reasonable

Posting and filing

Public records, when filed_._._._. 35

Rules and regulations affecting

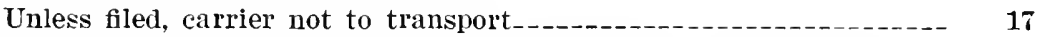

Federal reserve banks, directors of, being directors in other banks_._-_- $\quad 65$

Federal Reserve Board, to enforce compliance with Clayton antitrust act where applicable to banks.

Federal Trade Commission to enforce compliance with Clayton antitrust act where applicable to commerce other than commerce carriers and banks

Feeders, main lines may acquire

Fees:

Attorneys, part of costs.

Witnesses

Witnesses making depositions

Felony, embezzlement by president, etc., of common carrler.

Filing tariffs with Commission.

Final valuation of carrier's' property

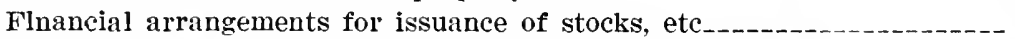

Financial operations, annual reports of carriers shall show

Financial reports, accidents not reported in_..._-_._- 86

Finding of fact:

Conclusice under Clayton antitrust act.

In report, in case damages awarded._._.

Prima facie in suits inrolving order for payment of money

Firms, complaints to Commission by

Floating debt, annual report of carrier.

Foreign commerce defined. 
Foreign country :

Deposition of witness in

Printing of rates through

Transportation to

Forfeiture :

Failure to comply with raluation section

Failure to file annual reports_... 43

Failure to keep records and accounts_._._._. 44

No person testifying subject to

Payable into Treasury and recoverable in civil suit__-_._._._. 34

Penalty for giving rebate

Form :

Accounts, etc., Commission may prescribe-_._._. 44

Addressing agent, when name not posted._._. 19

Of schedules _._._. 9,17

of valuation results_._._._. 39

Forwarding passengers and property from connecting line

Franchises, cost and value, annual report of carrier shall show _........ $\quad 42$

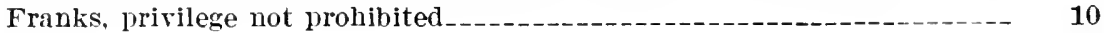

Free:

Baggage under mileage tickets

Transportation prohibited ; excepted classes________________ 9, 10,46

Freight depot included in term " railroad" ...._. 8

Freights, annual report of carrier

Fruit, necessary caretakers, passes to

Fulminate in bulk under explosives act

Funded debt, annual report of carrier._._. 42

Funds, embezzlement of, by president, etc., of common carrier_.___._._. $\quad 66$

Furloughed employees of carriers, passes to

Furnishing cars _._._._._. 8,11

Fuses under explosives act

Gas transportation, not subject to act

Gift to carriers from United States, etc., value of

Government:

Free or reduced rates

Messages by telegraph, etc_._._._. 8-9

Government-aided railroad and telegraph line act_._._._._._._. $\quad 73$

Goveruor of State, notice to, of tentative valuation

Grab irons must be provided:

On all cars

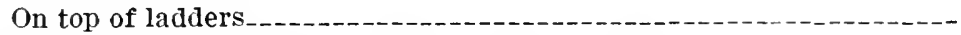

Grants from United States, valuation report to show

Greater compensation:

For shorter than for longer haul_...-...-

Than tariff rate-_._.

Gross earnings, raluation report shall show

Grounds and yards included in term " railroad"

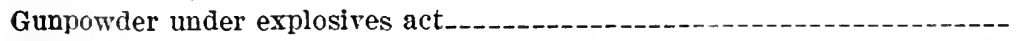

Hand brakes, cars must be equipped with

Handholds :

Cars must be equipped with

Must be provided with, or unlawful to use car

Handling explosives in transit, Commission to regulate 
Handling of property :

Included in term "transportation"

Page.

Regulations affecting

Wholly within one State

Hearing :

Before three judges to expedite suits in equity

Full hearing provided for

On petition to restrain violations of Clayton antitrust act_-_____ $\quad \mathbf{7 1}$

On protest of valuation of carriers

Preference as to reasonableness of increased rates._._._._._._._. 30

Protest of valuation

Report of findings under Clayton antitrust act to be in writing -_-_- 68

Temporary restraining order, without notice, under Clayton antitrust act.

History of carriers, valuation report shall show

Homeless person, pass to

9,46

Homes for soldiers and sailors, passes to inmates of

Hospital, inmates of, passes to

Hours of service act._._._._. 90-92

Common carriers subject__._._._._. 90

Compliance with act_____._. 91

Continuous service

Employees defined

Enforcement__-_._. 92

Exceptions to act

Off duty__._. 91

Penalty for violation

Prosecutions_._._._._. 91

"Railroad" defined___-_._. 90

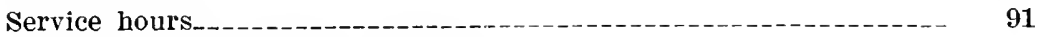

Telephone and telegraph operators

Jcing :

Charges to be printed

Included in term "transportation"

Immigration inspectors, passes to

Immunity from prosecution, witnesses entitled to, in certain cases.-.-- 21 ,

$26,54,55,59$

Import traffic, subject to act___.

Improvements :

Valuation of carriers_........ 40

In carriers' property 42

Increased rates:

Burden of proof on carrier, as reasonableness of

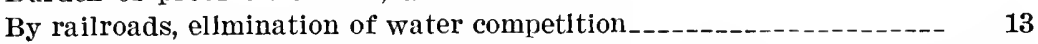

Incrimination, no person excused from testlfying by fear of $\ldots \ldots \ldots$

Indigent persons, passes to

Infirm employees of carriers, passes to

Information :

Commission may require of carriers on valuation

Concerning business methods of carrier-_-_____- 25

Concerning shipment, disclosure of

In relation to rates, etc., annual reports of carriers shall contain _-_ 43

Special examiner, who divulges, penalty________._. 45

Value of property, may be required._._._. 40 
Initlal carrier:

Page.

Bill of lading to be issued by

31,45

Liable for loss or damage on through shimments_...................

May have recourse upon carrier responsible for loss or damage...-

Injunction :

By district court, involving Commission's order

Commission's order's, appeal.

Preliminary, not to issue without notice under Clayton antitrust act_

lieasons for issuance shall be specific under Clayton antitrust act.---

Relief by, against loss and damage under Clayton antitrust act.-..--

To restrain rebates

Temporary-violations of Clayton antitrust act

Injured person, hurt in wreck, pass to

Injury :

Accidents to persons, etc., to be reported

False statement of, by shipper

Initial carrier liable for, on through shipments

Inmates of hospitals, etc., passes to

Inquiry :

Commission may institute, on its own motion

May be prosecuted by one or more Commissioners

Inspection :

By carriers

Must be made, boiler-inspection act

Inspectors :

Chief. (See also Chief inspector.)

District. (See also District inspector.)

Enforce safety-appliance acts

On medals of honor committee.

One for each district, boiler-inspection act

Post-office, customs, and immigration, passes to -

Shall not be interested in patented appliances

To investigate under medals of bonor act

Instrumentalities:

Allowance to person furnishing

Included in term "transportation"

Insular possessions, Clayton antitrust act, applicable to

Interchange:

of cars

Passes anthorized

$10,46,47$

Telegraph business with Government-aided line__._____....... $\quad \mathbf{7 4}$

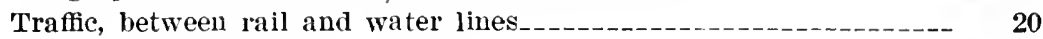

Traffic, facilities for

Interchangeable tickets._._._-_._- 47

Interest :

Complainant's lack of, no ground for dismissal__.___._._. 28

On debts, annual report of carrier. 42

Railroads not to have any, in competing water lines..._._._._. 13-14

Interlocking directorates _-_-_-_-_-_-_-_-_-_- 64, 65

Interlocutory injunction, Commission's order

Intermediate rallroad, through route to include

Intermediate rates, through rates in excess of 
Interstate Commerce Commission :

Page.

Annual reports to Congress

Appointment of Commissioners

Approve-

Examinations for district inspectors.

Rules for boiler inspection

Authority to relieve, from fourth section

Bids for purchases between corporations to be supervised by_._._._. 67

Carrier's agent's name filed in office of

Chief inspector shall make annual report to

Commissioners not to engage in other business................ 24-25

Compensation to be fixed by, for transporting employees in valuation service

Consent of, to change rate of parcel post___._.

Creation of

Designate appliances.___._. 83

District inspectors appointed by

Duty of-

Accident-report act

Ash-pan act _..._._._._. 93

Hours-of-service act__._._._._._.

Safety-appliance acts________._. 85

Employees of

Enlargement of, provided for

Enumeration of powers not exclusive

Expenses, how paid._- 37

Final appeal to, boiler-inspection act._._. 99

Information as to violations of ash-pan act__._.

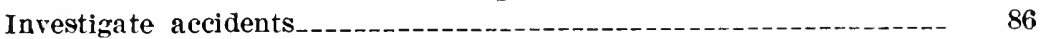

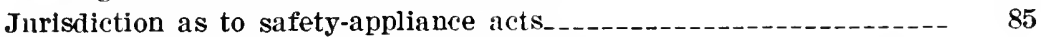

May apply to court for enforcement of order

May determine elements of classification and form of valuation

results _-_-_-_.- 39

$\mathbf{M}_{\mathrm{al}} \mathbf{y}$ determine its own procedure

May establish through routes and joint rates___- 30

May extend time for compliance-

Safety-appliance acts_______._. 81,84

Hour's-of-service act_____._. 91

May grant rehearing

May institute inquiry on its own motion

May modify requirements of section 6

May order switch connection, if practicable__._. 11

May order testimony taken by deposition._._. 26

May prescribe division of joint rates_._. 30

May prescribe maximum charges _._._._._. 29

May prescribe uniform system of accounts

May suspend and determine propriety of new rates..... 29

May suspend or modify its orders

Not more than four commissioners from same political party _..._. $\quad 48$

Pecuniary interest of Commissioner._- 36

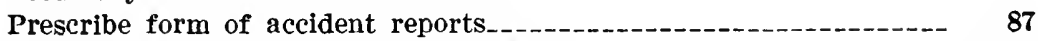

Production of books, papers, etc., before

Quorum, majority constitutes_..-_._- 36 
Interstate Commerce Commission-Continued.

Regulations for transportation of explosives.

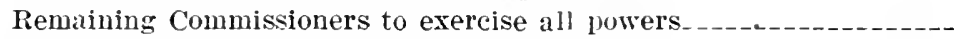

Report and decisions to be published, etc-_-_._.

Reports of purchases by carriers to

Reports to Congress on physical valuation work_._-_._._._.....

Salary of Commissioners._.

Term of office of Commissioners, seven vears_______________._. 36, 48

To approve charges of Lake Erie \& Ohio River Ship Canal_-_..----

To determine question of competition between rail and water lines_-

To enforce compliance with Clayton antitrust act, where applicable

to common carrier.

To inquire into management of business_._.

To investigate and report value of property of carriers............

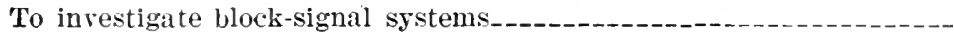

Vacancies provided for

Valuation of carriers' property by

Violation of hours-of-service act-

Interstate commerce defined.

Interveners, proceedings before Commission or board under clayton antitrust act.

Inventory of property of carriers

Investigation :

Commission may institute, on its own motion

Commission to investigate practicability, etc., for switch connection.

Commission's power to investigate accidents.

Defective boiler accidents

In such manner and by such means as it shall deem proper------

In such manner and by such means as it shall deem proper.-_-_-_.

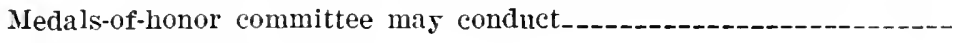

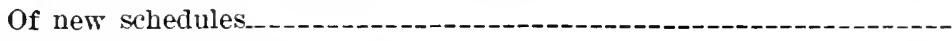

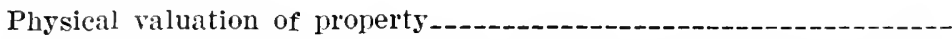

To determine question of competition between rail and water carrierInvestment, acquiring stock for purposes of, not prohibited._-_.-_-_-_Irreparable damage, issuance of temporary restraining order without notice against, under Clayton antitrust act

Joint interehangeable 5,000-mile tickets, issuance of Joint plaintiffs may sue joint defendants in conrts on awards of damages_ Joint rates:

Between rail and water carrier to foreign country via Panama Canal_ Commission may establish__._._._.

Commission may prescribe maximum

Divisions of

Notice of change-_._.

Printing and posting schedules_._.

Rail and water carriers

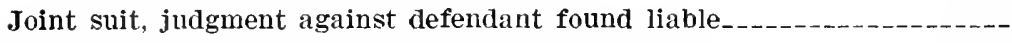

Joint tariffs must name carriers participating

Jointly liable, carrier and shipper, for unjust discrimination._.......--

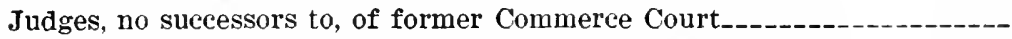
Judgmeut, joint suit, recorery against defendant found liable_............Judicial notice, Commission's seal 
Jurisdiction ( see also Interstate Commerce Commission) :

Page.

Circuit and district conrts for writ of mandamus___._._. 47

Circuit court of appeals-

For enforcement of, under Claytou antitrust act

Under Clayton antitrust act, exclusive

Commerce Court transferred to district courts_____ 50

District courts-

For violation of act._._..................... 22

$\begin{array}{ll}\text { To restrain violations of Clayton antitrust act } & 70\end{array}$

Offenses under pass provision____._. 10

State and Federal courts, Clayton antitrust act____ 66

$\begin{array}{ll}\text { Traffic through Panama Canal_._. } & 19\end{array}$

Just and reasonable charges.......... 8

Justification of switch connection, Commission to investigate

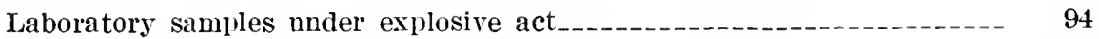

Ladders, cars must be equipped with

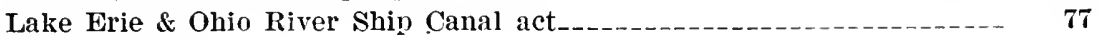

Land grants :

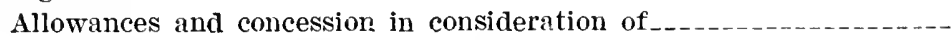

Value of

Lands of carriers, valuation of

Lateral line, application of, for switch connection

Iease :

Conditioned upon lessee not to deal with competitor, mlawful .....-.

On competing water line, railroad not to have

Leased line included in term "railroad" 8

Legal rate, rate filed held to be

Jegislation, recommendation for additional

Less compensation :

For longer than for shorter haul__._. 12

Than tariff rate._. 17

i.etter :

Notice of tentative valuation by registered___. 40

Telegraph, etc_._.

Liability :

Carrier not relieved from__._. 84

Exempting carrier from____. 45

Existing, not affected._. 50

Initial line for damiage._._._._. 45

Liens of Government on Government-aided telegraph lines_____._. $\quad \mathbf{7 4}$

Life saving on railroads_-_._._._. 88

Limitations :

Complaints for the recovery of damages filed within two years.-.--

One year for enforcement of order for payment of money-..-.-.--

Six years in rebate cases_._._. 58

Limitation of actions, hours-of-service act______ 91

Limitation of liability of carrier. 45

Linemen of telegraph and telephone companies, passes to

Iive stock:

Hauling defective cars by chains permitted.........................

Necessary caretakers, passes to____._. 9-10

Loading explosives, Commission to regulate 
Local rates, through rate in excess of combination of

Locomotives (see also Ash-pan act; Boiler-inspection act) :

Excepted from ash-pan act.

Page.

Must be provided with ash pan

Power driving-wheel brakes

Long and short haul provision

Long commodities, brakes on cars used in haulin:

Ioss and damages, injunctive relief against, under antitrust act_......Mailable matter under parcel post.

Mail Service, Railway, passes to emplocees

Management of business, Commission to inquire into

Mandamus :

District courts to compel by compliance with valuation provision

41.42

Peremptory writ, when used

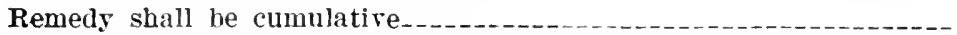

To compel carrier to comply with act

To compel furnishing of cars and movement of trallic

To enforce order of Commission against Gorernment-aided lines_-_-

Maps to be furnished to Commission by carriers

Marking explosires, Commission to regulate

Marking packages for transportation

Maximum rates and charges, Commission may prescribe

Medals of honor act.

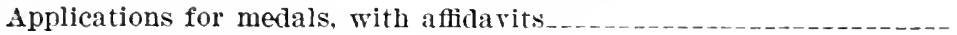

Approval of President..............

Committee to consider affidarits

Design of medal

89

90

89

Expense provided for

Inrestigation by inspectors

Life-saving, medals for

President to grant

Proof must be offered.

Regulations governing awards.......

Rosettes and ribbons

Memoranda :

Commission's agents shall have access to

Form of, Commlssion may prescribe

Mileage:

For witnesses.

Tickets, issuance of, not prohibited.........

Military traffic, to be expedited in time of wal.

Milk, passes to necessary caretakers of

Ministers of religion, passes to

Minor children of deceased employees of carriers, passes to

\section{Misdemeanor :}

Committed by corporation

Common carrier and officer purchasing, etc., without bids

Discrimination by Government-aided lines._. 
Misdemeanor-Continued.

Page.

For carrier to permit transportation at less than regular rates..... 22

For disclosing information concerning shipments____._. 32

Mutilation of records___._. 44

Shipper inducing carrier to discriminate

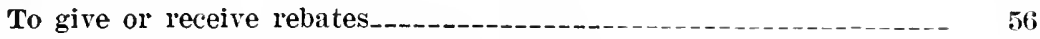

To obtain less than regular rates by shipper....... 23

Violation of act_..._. 22

Violation of pass provision_._-_._- 10

Misstatement of rate, penalty for

Modify, Commission may, or suspend its orders_..._._._. 34

Money damages:

Award of, by Commission_............ 33

Order for payment of, to be enforced in courts_.............. 33

Money of carrier's:

Derived from sale of land grants__._. 39

Expenditure of, valuation report shall show___________ 38

Monopolies and restraints, expedition of suits in equity against__._._. 60

Monopolies, Clayton antitrust act_-___

Monopoly, acquisition of stock of competitor, prohibited__._._. 63

Monthly reports of accidents act. (see Accidents report act.)

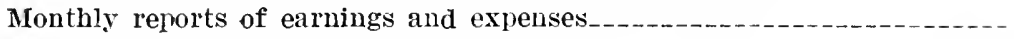

Motion, Commission may institute inquiry on its own__._-_._._._. 20, 27, 74

Municipal goverument :

Complaint by

Free or reduced rates for

Subsidy or donation from, to carriers

Munitions of war for military and naval forces, explosives act______._. $\quad \mathbf{9 4}$

Iutilation of records of carrier, misdemeanor._...... 44

Mutual savings bank, directors and officers in__._. 65

National homes for soldiers, passes to inmates of

Natural persons, immunity extends only to

Necessary agents, passes to

Net earning, valuation report shall show

Newsboys on trains, passes to

Nitroglycerin under explosives act-_._- 94

Notice:

Change in rates by Lake Erie \& Ohio River Ship Canal_______ 78

Change of joint rates._._. 16

Interlocutory injunction, application for-_-_-_-_-_-_-_-_-_-_-_ 51

Issuance of temporary restraining order without, under Clayton anti-

trust act _._.

$\begin{array}{ll}\text { Preliminary, not to issue withont notice under Clayton Act_-_._-_-_ } & 71\end{array}$

Service on Washington agents__._._._._._. 49

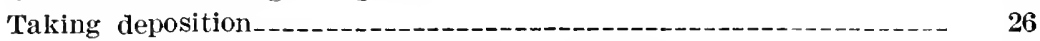

To be given on completion of valuation of carriers

Nurses attending persons injured in wrecks, passes to _._._.

Oaths and affirmations, any member of Commission may administer_..._- 36

Oath :

Accident investigations_-_._-_._-_._- 87

Annual report of carrier, how taken

Annual reports of carriers to be under._._. 43

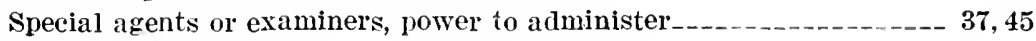


Offense :

Each day of agreement for pooling, etc., separate_................ 13

Each day separate, for failure to obey order under section_.._-_._._ 34 Office, principal :

Of carrier, venue of suit_._._.

Of Commission in Washington_._. 37 otticer:

Bank, eligibility of

Carrier prohibited from making purchases with another corporation having same

Embezzlement of funds by, of common carrier

In more than one bank where entire stock is owned by the other-.--

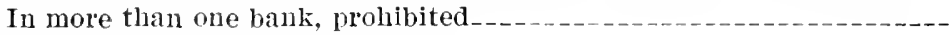

Liabiilty for violation of act

Of carrier, jasses to

Private bank and bank organized under United States laws___...... 65

Offices and supplies, Commission shall hire and procure_______... 37

offices of chief and district inspectors

official act, entered of record____. 36

Official seal, Commission shall have-______- 36

Offset against regular charges prohibited_____.

Oil locomotives excepted from ash-pan act_... 93

Oil, transportation, subject to act_-_. 7

Operating reports, accidents not reported in

Operation :

Government-aided lines

of competing water line by railroad_._. 13-14

Operator, period of duty, hours of serrice act___ 91

Orders :

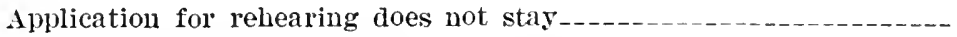

Carriers must comply with

Commission may appeal to courts for enforcement of, under Clayton

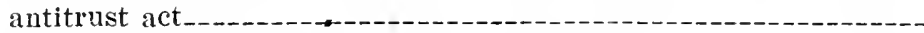

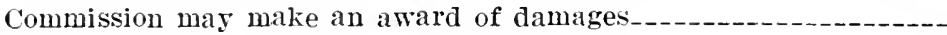

Commission may suspend or modify_..._._._.

Competition between rail and water carrier to be final__________ $\mathbf{1 4}$

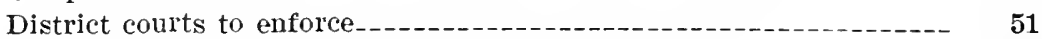

Enforcement of physical connection, Panama Canal

Enforcement of order for payment of money

Failure to comply with__..._._._._._.

Mandamus to enforce against Gorernment-aided lines_____._._. $\quad \mathbf{7 4}$

May be modified under Clayton antitrust act_________________._. 68

Payment of money _.......... 25

Prescribing maximum charges_____._._._._._._. 29

Procedure, petition for, from enforcement of order under Clayton

antitrust act._._._._._. 70

Report in writing stating

Restraining, reasons for issuance, shall be specific under Clayton antitrust act

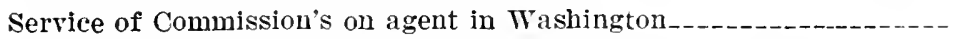

Shall continue in force two years._._.

Shall take effect within reasonable time for payment of money......

Supplemental orders

8


Orders-Continued.

Page.

Suspension or annulment

Switch connection, enforcement of -

Temporary restraining, issuance of, without notice, under Clayton antitrust act

To be issued where violation of antitrust act__..._._._._._._. $6 \mathrm{~S}$

Under Clayton Act does not relieve from antitrust acts_._._._._. 70

Organizations, complaint to Commission by

Original cost, valuation report shall show

Orphan homes for soldiers and sailors, passes to inmates of

Ownership :

Cars, facilities, etc

of competing water line, by railroad

Packages containing explosives shall be marked_______._._._. 95

Packing explosives, Commission to regulate__.........

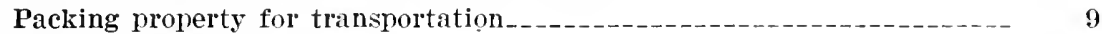

Panama Canal :

Jurisdiction over traffic through

Railroad not to have interest in competing water carrier operated

through

Via, from port in United States to foreign country

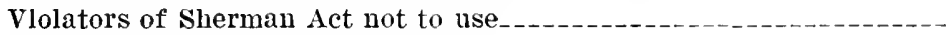

When certain lines subject to act._.....

Papers :

Commerce Court, sent to Department of Justice........

Commission may require production of

Courts may compel the production of

No person excused from producing

Parcel post_._.

Parties :

Complaints to Commission

Injunction and restraining order under Clayton antitrust act.-...----

Interested, may appeal from enforcement of order under Clayton

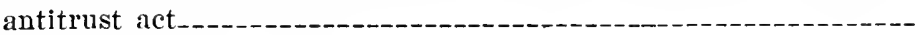

Interest, under Elkins Act.

Joint defendants may be sued on award of damages..............

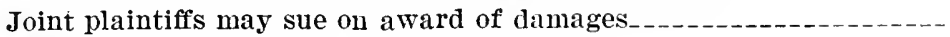

May appear in person or by attorney

May be summoned before court under Clayton antitrust act........-

Notice to, of tentative valuation

Shall be furnished with copy of report

Passengers and property from connecting line

Passenger railways, street electric, through ronte and joint rate with----

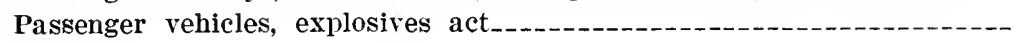

Passes:

Interchange of

Prohibited and exceptions.......... 9.46

Patents, no inspector shall be interested in

Pecuniary interest in proceeding, commissioner shall not participate_-_-_ $\quad 36$

Penalty :

Accidents report act

Ash-pan act._._. 92

Boiler-inspection act

Common carrier and officer purchasing, etc., without bids_..._-_._-_ $\quad 67$ 
Penalty-Continued.

Page.

Compulsory testimony act__._. 54

Corporation subject to

Disclosing information concerning shipments_._._-___________- 32

Discrimination by Gorernment-aided lines_______._- 75

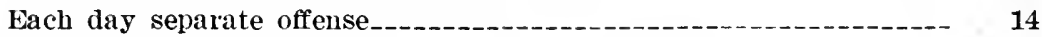

Embezzlement by president, etc., of common carrier._._. 66

Examiner subject to, who dirulges information_._._._._._._._. 45

Explosives act..._.

Failure of carrier to file annual report____._. 43

Fallure of Government-aided lines to file annual reports_._._._._- $\quad \mathbf{7 6}$

Failure to comply with regulations or order of Commission_._._._. 18

Failure to obey order under section 15

Failure to publish rates, Elkins Act__._. 56

False billung, etc., by carrier._- 22

Falsifying record, etc_._._._._._._._. 44

Greater or less compensation than published tariffs_____________ 47, 56

Hours of service act._._. 91

Inducing carrier to discriminate_._._-_._- 24

Misstatement of rate in writing

No exemption from antitrust laws by enactment of Clayton Act__.- 64

No person testifying subject to, in certain cases_-_-_-_-_-_ 21, 26, 54, 55, 59

Obtaining less than regular rates by fraud_._._. 23

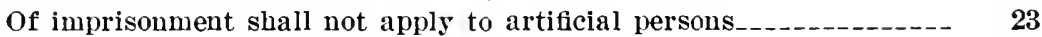

$\begin{array}{ll}\text { Preventing bidding or competition among bidders_-_-_-_-_-_-_-_ } & 67\end{array}$

Refusal to comply with order of court_-_-_-_- 26

Refusal to testify

Safety-appliance acts _....... 80, 82, 84, 85

Violation of act

Violation of valuation provisions _... 41

Violating pass provision

Pending cases not impaired or affected

Pensioned employees, passes to

Percentage of power brakes_____. 82

Peremptory mandamus when question of compensation raised_._...... 48

Perishable freight, chains may be used in hauling

Perjury may be punished_._-_._- 54

Personal baggage ...... 9

Personal inspection of boilers

Persons, injured in wrecks____. 9-10

Pestilence, carrying passengers free in case of 10

Petition :

Complaints to Commission by

Shall state facts briefly

Physical connection :

Between lines of rail carrier and docks of water carrier-______- 19

With lateral branch line or private sidetrack_-_._- 11

Physicians :

Attending to persons injured in wrecks, passes to

In employ of carriers, passes to

Pipe línes subject to act

Pleading:

Complaint to Commission by petition....................... 27

Propriety of new rates determined without formal 
Political parts, number of Commisiomers from same-

Pooling of treights and division of candings forbidelen

Port of entry or trinsshipment

Ports, proportional rates to and from.

Posting :

Name of carrier's agent

Schedules

Schedules of Iake Erie \& Ohio lairer Ship Cimal

service by, in office of Commission's serestaly-

Iostmastel Genelal, anthority of, not impailed_....... ir

Post-ofice inspector, passes to._...

loultry. necessily caretakel, passes to

l'ower's:

And duties of Commission

Enmmeration of, not exclusive

Power brakes must be provided _............. \$2

Practices:

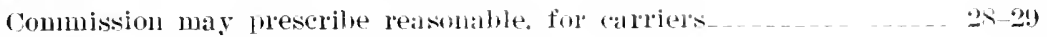

Commission may prescrilue lules of 36

Of carlier, must be just and reasomable

Practicability of switeh comnection. Commissim to investigiste..... 11

Preference:

Militaly traflic in time of wall-

Unreasonable, nnlawful_...

rejudice, unreasonable, unlawful _._.

presenting property for transportation. legulations affertills_........ !)

I'resident :

Apyoint chief inspector and two assistants__ $96^{\circ}$

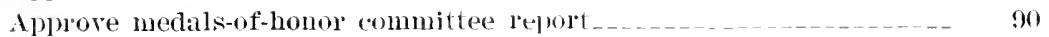

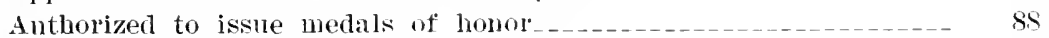

May remore Commissione:- 24

To appoint Commissioner._... 48

Iress messiges...

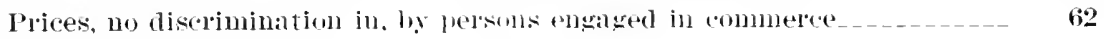

Prima facie evidence:

Final valuation of carlerier. 41

Final valuation of propelty 41

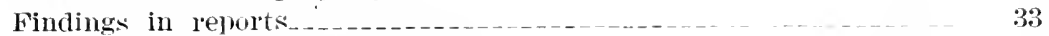

Tariffs, etc. filed with Commission_... 35

Iriucipal office of calrier, reune of suit__. 51

lrincipal office of Commission in Washington

l'rinted for distribution, ammual rejorts__._. $2 S$

Printing schedules _._.

Plivate:

Banker, director. etc., in bank oramized muler Luited states laws --

Car service _.............

Docks. switch counection to

Individuals, subsidy or donation from, to carriers____. $3 !$

Sidetrack. switch romnection to

Privileges :

None unless specified in talrift

Printing and posting

$\left(\right.$ iti $171^{\circ}-14-9$ 
Procedure:

Appeal from enforcement of order under Claston antitust act

Circuit court of appeals. enforcement of order under Clayton Act

Commission may determine its own

District courts, suits to enforce or set asicle orler:

Investigating complaint under Cliston antitrust act

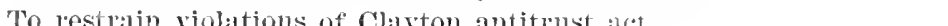
Process :

Service of, complaints, etc., under Clayton antitrust act

Service of, where defendant carriel has its principal ofire

Service on Washington agents

Production :

Books and papers, action for damages

Books, papers, tariffs, etc.

Profiles to be furnished to Commission by carriel.

Profit and loss, billance of, annual rejort of cilrier shill show -

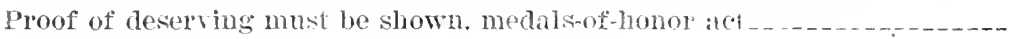

Property of carriers:

Commission's agents shall have aecess to

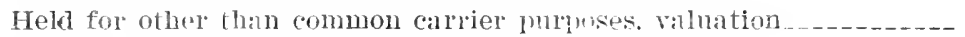

Report of ownership of Government-aided lines...................

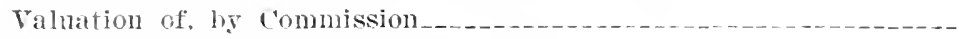

Prolortion of joint rates_____.

Proportional pates to and from ports defines].

Proposed rates, suspension of

Propriety, fommission ma determine, of new shombles.............. 2!)-30

Prosecution :

Cost and expense of -

Jurisdiction of State and Ferleril courts. claston antitrust atet_-_-_

Proper district for

Protest :

Of valuition

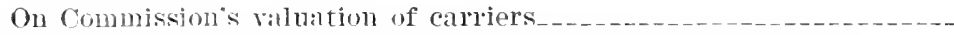

Proxies, accuisition of stock and roting by competitor, prohibited Public:

Inspection of recolds and data on valuation

Inspection of chetules, etc

Proceedings on request of party interesterl_........................

Records, titrifts, etc., filed with Commission shall be preserver as_.--

Reports and lecisions of Commission

Scherdules of Lake Erie \& Ohio River Ship Camin

l'ublished piates:

Failure to puhlish rate a misdemeanor

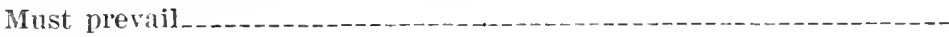

Pulchases:

Carrier prohibited from making, with anotber corporation having

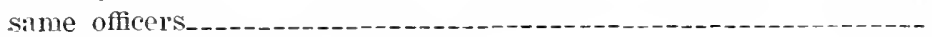

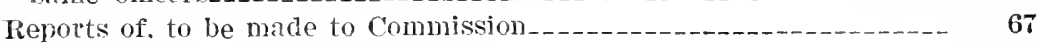

Qualification of Commissioner's___... 24, 46, 48

Quortm, majority of Commissioners for transiction of bnsiness__-_-_-_ 36

Quotation of rates in writing, when to be furished_...-............. 18 
Railroad:

Page.

Government-aided

State, commissioners. complaints by

Subject to act, when

Young Men's Christian Association, lanss to traveling secretaly....

Pailroad defined

Boiler-inspection act

Hours-of-service act_._._._.

Railway Mail Service, employees, patsses to _. (10

Rates:

Annual report of carrier concerning

Device to avoid regular._.....

Filed or participated in, deemed legal__... 5

Filing and posting

Government-aided lines._.............

Just and reasonable________._._._.

Lake Erie \& Ohio River Ship Canal..........

Less, for longer thau shorter hatul_..... 12

Maximum, Commission may prescribe_........ 2?

New, Commission may determine prolntiety.

Proportional, to and from ports._._. 20

Public records, rates filed with Commission ale 35

Published, to be strictly observed 17

Regulations, reasouable, affecting $\quad 6,15-16$

Rules, reasonable, affectirg _

Suspension of, by Commission____ 29-30

Unduly preferential or prejudicial_...

Unless filed, carrier not to transport 17

Written statement of -_._._._.

Real property, valuation of _._._.

Reargument, equal division of opinion muler expediting ant 61

Reasonable charges:

Burden of proof

Commission to determine reasonableness _._.

Lake Erie \& Ohio River Ship Canal____._._._. it

Nust be

Order of Commission preseribing

Reasouable time, answer to complaint to be marle in $\ldots \ldots \ldots$

Rebate:

Injunction against ................. 5.

Lake Erie \& Ohio River Ship Canal_...

Offering or soliciting, a crime_..._._._._. 12, 56

Penalty_._._......... 22. 56

Prohibited _....._____.

Receipts :

Carrier shall issue

Exempting carrier from liability

False. by shipper, to obtain refund, etc

Reasonable regulations affecting

Receipt of property included in terw "transportation ". 
Jiereiver: :

Page.

Accomint of

Heluded in ash-pan aret.

l'enalty for violation of valuation purision lecerising of property :

For transpoltatiom

Within one State not subject to act

liereiving passengers and molerty fom commorimg line.

Recommendation for alditionall lexislation

liecords of (alliel's:

(ommission's algent to have alcess to

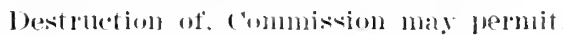

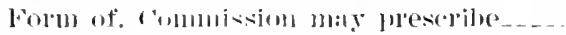

Fo lo fuluistorl to foumission

Recolols of ('mmmissions, pmblic inspertion of

liedured lates, jalsies am: l exceptions.

reduction in rates:

(ammission may requile

lake Frie \& Ohio River ship cilual

To meet competition of water romte

Reexanunation of defertive boiles:

Refind:

False means log shipled to whath

of portion of tariff rate

Refusal to testify or poduce docmments

Regulations:

Annual repont of carrier concernins

Carrjels: must be just and reasomable

carriers. to be printed aml posted

commissions. fililure to comply witls

Commissim may presclobe

commisionts, to have full force of law

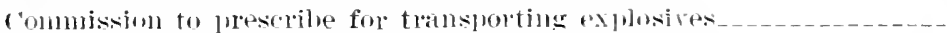

forvelnine awald of medals-

Rehearring:

Application for. shall not excuse compliance with orler

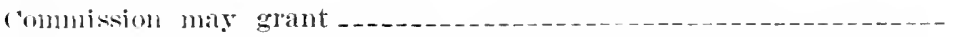

Report and order under clayton antitrust act. may be morlified

Rejertion, tariff: may be rejected for filing

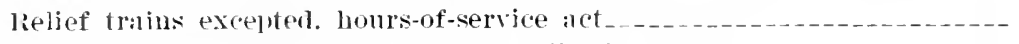

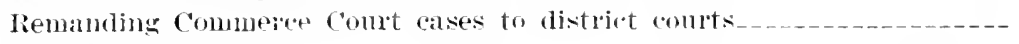

Remedies:

Civil, enactment of Clayton Act dues not exempit antitrust laws._-_

Complaint to Commission or suit in and

provision of act in addition to..............

Under existing law not barred. 
Reparation:

Page.

For injury

Report shall include findings of fact

Suits for.

Repeal:

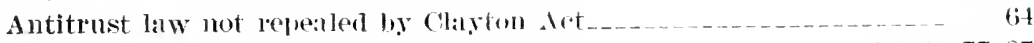

of laws in conflict.

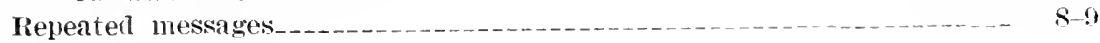

Reprrts:

Accident, form of _._. 8 i

Chief inslector to make_.......

False, of weight, by arrier or shipper.

Not erialence._._. $87-100$

lieprorts of carriers:

As to value of property, may be required_... 40

Carriers' engineer's reports to be furnished to Commiscion _._. 39

Commission may requile and prescribe method of making__._._. 42

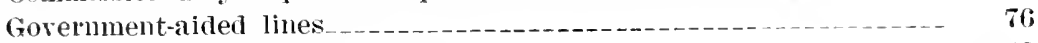

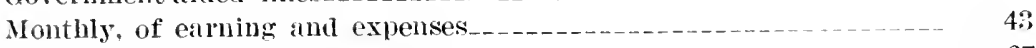

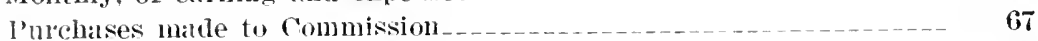

Special or periodical _._._..._. 43

Statistics in, are public records...

'To be filed by September 30 of each year.... 43

Under boiler-inspection alet _.............. 99

Reports of Conmmission :

Annual-

Printed for distribution

To Congress _..... 46

Competent as evidence

Concerning valuation work__._______ $\$ 9,40$

Must be entered of record and furnished parties........ 2S

To Congress, block-signal systems 101

To Congress, on valuation of carriers________ 39,40

Under Clayton antitrust act to be in writing 68

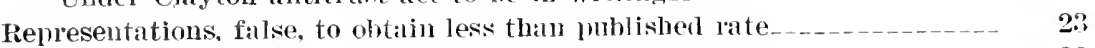

Reproduction, cost of

Reproduction cost, valuation report shall show______. 38

Residence of petitioner, venue of snit

Restraining order :

Reasons for issunce shall be specific under cliyton antitrust act_-_ T2

Temporary, issuance of, without notice, mder Clayton Act______ 71

Restraints and monopolies, expedition of suits involving

Restraints in commerce. Clayton antitrust act__.....

Retroactive:

Amendments to act shall not be 1 _... 47, 40,50,60

Clayton Act not to be-... 64

Interlocking directorates._._. 66

Return of cal's....... 8

Revenue of carrier:

Carrier's report of

Valuation report shall show earmings...___. 38

Revenue trains, hauling defective cars by means of chains__. S.

Reverse, Commission may, on rehearing, its orders_...... 86 
Revision of villuition

Page.

Right of way:

Commission's agents shall hatre aleress to to _ n

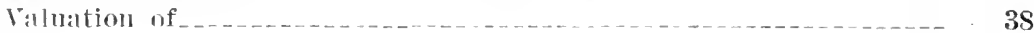
Risli :

Employees shall not issume _._.

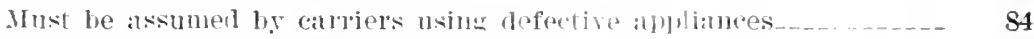

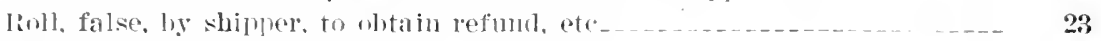

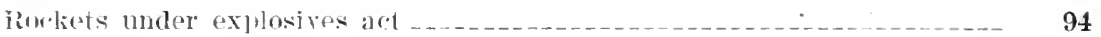

Routing:

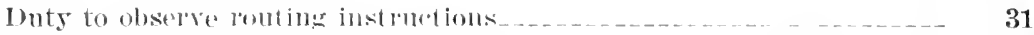

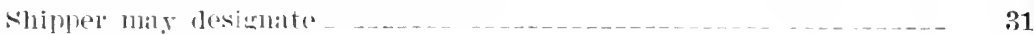

linles: ind instructions:

Cilliers shall file

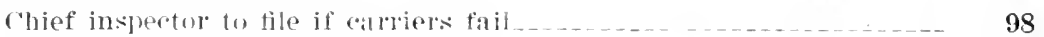

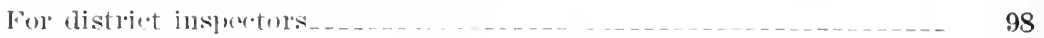

May be clialladed _... 98

shall be ajproved by rommissimn_... 98

Rules of cal'rier":

Commission mily presuribe.

Must be just and reasmable.

To be printerl and posterl _._.

Rinles of Commission:

Commission's rules to have full force of litw

Rnles of procednres___. 36

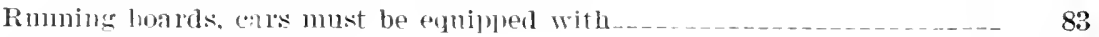

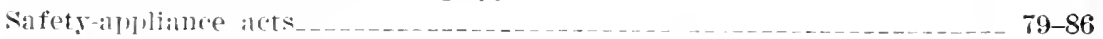

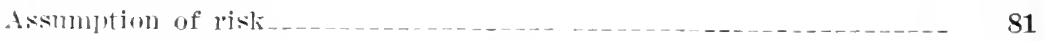

Antomatio rouplers _......

Calliols smbject to alot

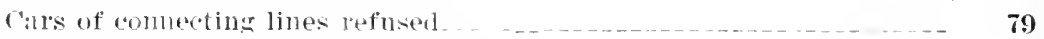

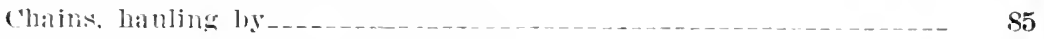

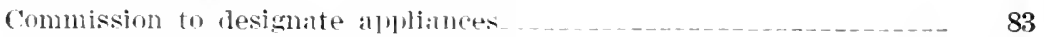

Compliance will act. time for._._._._._._. S4, S5

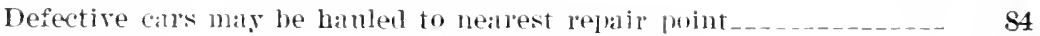

Drawbars _...

Driving-wheel and train blilkes._.

Enfolcement by coumission__._.

Exceptions _......... S0, 82

Grab irons and handholds____._. 80,83

Inspectors providerl for

Laddel's _........ 'S3

Liability of carriers_...

Penalty for violation _._.

Percentage of train-braker (all:

Power brakes..._._. 82

Rumning boards, cars to he equipperl with

Sill steps, cars to be equipled with $\ldots \ldots \ldots \ldots \ldots \ldots$

Sailors' homes, passies to inmates of

Salaries:

Carriers' employees, annual report of calrier shall show-_._._-_._- 42

Commissioner's' -_._._._._._. 36,48

Commission's employees, annual repori of Commission shall sbow_-_- 46 
Sale, conditioned upon purchaser not to deal with rompetitor, unlawful_

Sample:

Baggage

Explosives for labol'alory eximination

Satisfaction for complaint hy calluels

Savings bank, mutual, directors and officers in.

schedule of rates:

Commission mas deternine jouniety of new

Commission may areseribe forms

Filed with Commission ale pullic records

Iake Erie \& Ohio River Ship Canal.

May be rejecter

lo be published

Tnless filed. carrier not to trinspont

Seal of Commission, judicially noticed.

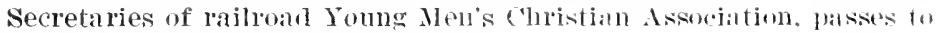

Secretary of Commission :

Commission shall alpuint

Custody of l'ecorrels

Designation of Washington agents filed in office of

On medals of honol committee.

Service of notice ly posting in office of

Securities of carriers. valuation report shall show

Senate:

Appointment of boiler inspector's affirmed ly

Appointment of Commissioners affirmed by--

Service:

Complaints, etc. moler cliyton antitrust act

How made

Order of Commission on designated agent in Washingtoll..........

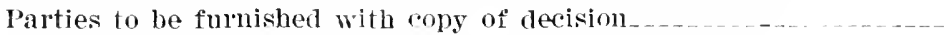

Process, where defendant arrier has its princijal office

'Tentative valuation notice hy regristered letter'

Washington agent of carrier.

When no Washington igent.

Sessions of Commission may be held in any part wf tuited states......-

Severally liable, carrier and shipper, for discrimintion ..............

Sherman Act, violators of, not to use Panama Canal....................

Shipper :

Application of. for switch comnection

False billing. etc. by

Infornation concerning shipment of

May desiguate routing

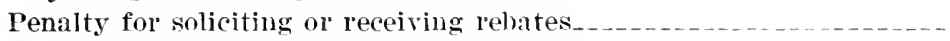

When cars may be refused from 


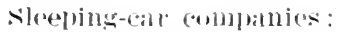

Page.

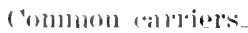

Sociely. commplaint to commusiom by

sijecial:

Agents-

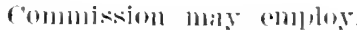

44. 45

lemalty for alivuleing information

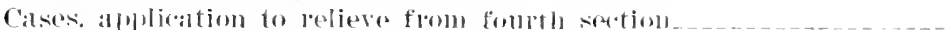

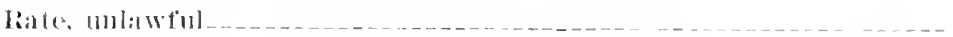

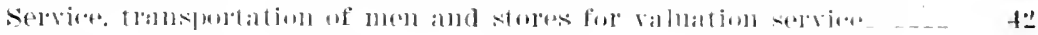
simrs:

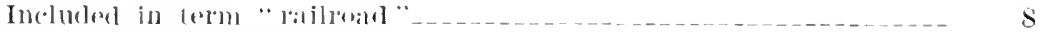

To dork uf' water line

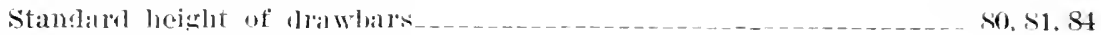

Stalle:

Commissim. (ool)teration will

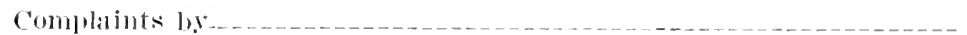

Conrt--

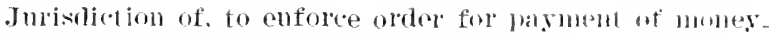

:3:

Iiemoval of suit under section 29 from

Governments. frece oreduced rates for

Homes for disabled rolumeer soldiurs. passes to immates of

Subsily ol domation from, to carrier.

9. 46

Transiortation not subject to aret

3S, 39

T-S

23

$s$

$4: 3$

3.1

S:;

steps, sill, calls must be expipped with

stock :

Lequisition of competitor. mohibited

(i;)

24

Commissimers shall not own, of carrier.

$1: 3-14$

3

42

21

stopmage. deriae to prevent continuous carriage. mbiaful

storiage:

Chanes lo he printed and filed _...

Inclnded in term " transportation "

Regulations alferting_.....

Within an» Stalle not subject to alot _... siticet:

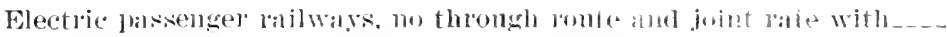

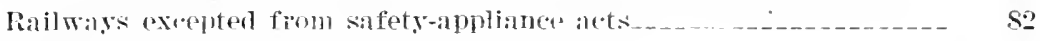
simpluas:

Commission nuty renthine allendance of rititess ig.

Duces tecum _._.

Parties may be smmmoned before comt undel. rlistom Ar

signed by any member of Commissiom 
Subpenas-continued.

Page.

Witnesses-

Aceident inrestigitions

Block-sigllal invesligations.

Subsidialy eorporatioms. formation ot, not prohibited

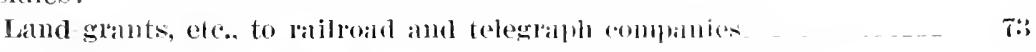

Valuation reprort to show

Suits:

Courts or commlant to Commision for datumines

Ordel of commission-

Expedition of

Intisiliction

Removil from sinte court of, muler soction 20

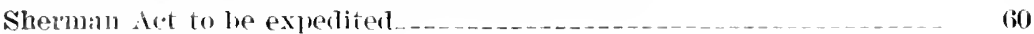

Venve _...

Superammited empluyees of carriers. pisses to

Supplemental moler. mescribing proportions of joint rates

Supplies, carriers probibited from making purchases with amother colporation having same officer.

Supreme Court:

Appeal from suspension or anmulnent of Commissions omeler

Appeil to, under experliting act

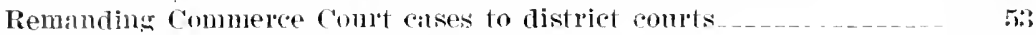

Surgeons in employ of carriers. pakses to

Surplus fund, anumal report of carrier shitl show

Suspension of new rates by Commission _...

Suspension of orders:

By Commission

By the couts

Switch comuection:

Between rail and waler line

With lateral branch line or mivate side track

Switches included in term " laillo; "

\section{Tariffs :}

Commission may detelmine mopriety of new

Commission mas require protuction of

Failure to publish a misdemeanor._.

Filed with Commission ale lublic reconeds.

Filing and publishing

Form of carrier may prescribe

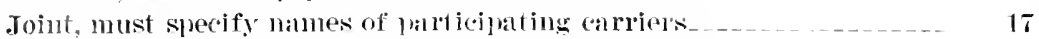

May be rejected

No person excused from prolucing

Rates to be strictly observed 1 T

Jnless filed. carriers not to trausport

Telegraph and telephone operator's. hours-of-service act

Telegraph companies :

Charges shall be just aud leasonable

Fxchange of passes ol franks with common callier._........ 10

Wxchange of serrices with common carrier. 9 
Telegraph companies-continned.

Government-aided

Page.

linemen of., lasses to.

Messiges, classificaltion of -

Subject to act

Telephone companies:

Charges shall be just and reasonilble

Exchmege of passes or franks with commun colluter.

Exchange of services with rommon carrier--

Linemell of. misses to

Messages, classificatiou of

Subject to alct _...............

Telegraph line comnecting with Govermment-aided line

Temporary injunction, riolations of clayton antitrust acet

Temporary restraining order, issume of. without notice. muler 'layton antitrust act

Tentative valuation

Terminal chirges printed, posted, and filed

Terminal facilities:

Included in term "railroad"

Use of. ly another carrier

Terminuls, of carriers, valuation of

Territories:

Complaints ly commissioners of

Transportation within, or to or from

Faluation of carriers property in.

Territories included in:

Ash-pan act

Boiler-inspection act

Safety-apuliance act

Testimony :

Accident investimations

Agents or eximiners

Compulsory act

Immmnity of witness in action for damage

Proceeling before Commission or board to be reduced to writing

Through bill of lading, carrier shall issue

Through rates in excess of combination of local rates

Through rontes:

Between rail and water carrier to foreign comntry r' I Panama Camil

Carrier to establish

Commission may establish

Entire length of railroad.

Greater compensation than aggregate of intermediates...........

Rail and water carriers

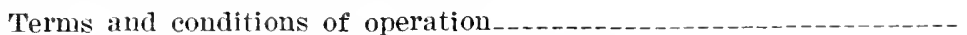

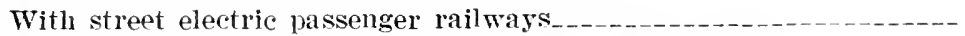

Throngh shipments, initial carrier liable for loss or damage

Tickets :

Commutation, excursion, and mileage

Interchangeable mileage

Issuance, form, and substance

Time schedule. change of 
Tolls, Lake Erie \& Ohjo Rirer Ship Canal.

Torpedoes under explosives ict

Tracks :

Included in term " railroad"

To dock of water carrier

Use of, by another cirrier._. 12

Traffic, writ of mandamus to compel morement of

Train brakes:

Cars must be equipled with

Percentage of cars in trim

Transfer in transit included in term "transportation"

Trimsport traffic. writ of mindamus to compel carrier to

Transportation :

Duty of callier to furnish

Employees engaged in raluation.

Regulations affecting

Subject to act

What the term includes.

Wholly within one state, not subject to inct__... T-S

Transportation of explosives act__.......

Exceptious of provisions._....... 94

Explosices not to be cirrierl

Marking packages__...__ 95

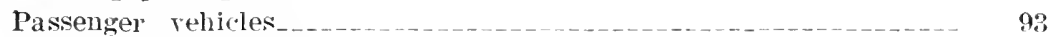

Penalty for violation

Regulations affecting _ 94

Transshipment, port of

Traveling expenses, boiler-iuspection act

Traveling secretaries of railroad Young Men`s Christian Associations,

passes to _........................

Treasury of the United States. forfeiture payable into

Trust company director, officer or employee in more than one, prohibited

Ultra vires contracts of Government-aided lines____-_-_- 75

Undue discrimination, induced by shipper, misdemeanor._._._._._. 24

Undue or unreasonable preference or advantage forbidden_______._. 12

Undue or unreasonable prejudice or disadvantage forbidden_________ 12

Uniform system of accounts, Commission may preseribe_._._______ $42-43$

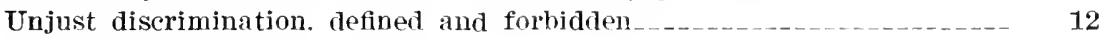

United States :

Forfeitures payable into Treasury

Free or reduced rates for

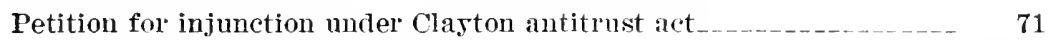

Subsidy or donation from, to carriers_________________ 38,39

United States Board of Mediation and Conciliation. transfer of Commerce Court property to

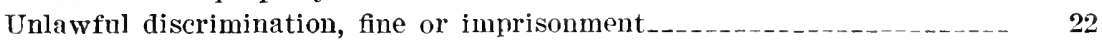

Unrepeated messages_._._.

Vacancies, remaining Commissioners to exercise all powers_______._. 25

Valuation; property held for other than common-carrier purposes_.... 38

Valuation of carriers :

Carriers required to cooperate

Foxtensions and improvements 
Valuation of carries-Contimed.

Page.

Final luilua farcie evilenc't.---- 41

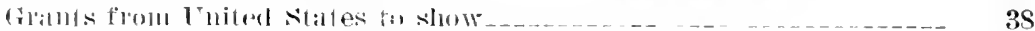

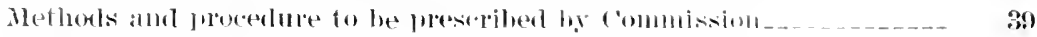

l'enalty for violation ol fHovisimls__._. 41

Reports to romingess_._.

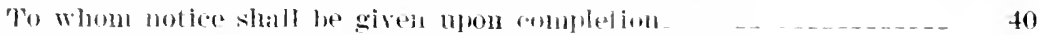

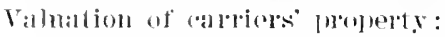

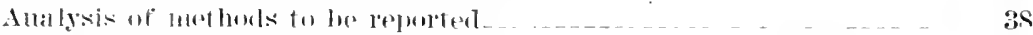

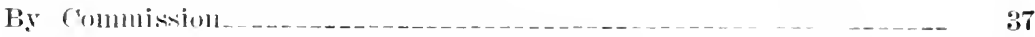

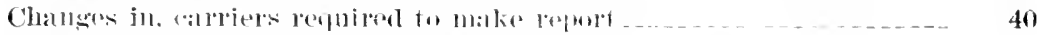

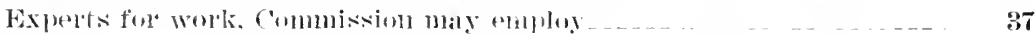

Finill-

Literet

41

If no jmolest filed within 30 days _ _ 40

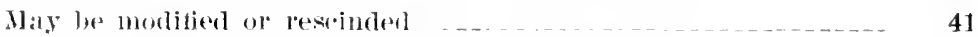

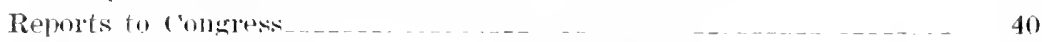

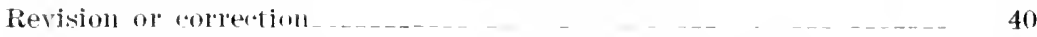

Tentative

What raliation rojorts slall show _ 37 Value:

Falke stalement hy slipuel.

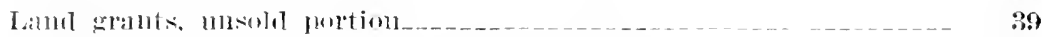

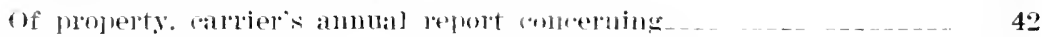

()f service, lnles affecting

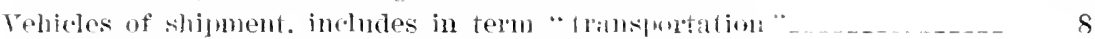

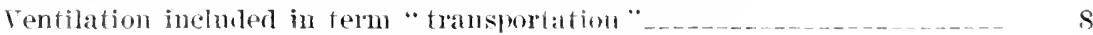

lenue, suit to enforce or set aside oldex._._._._._. 51

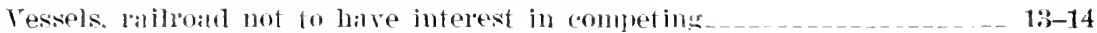

Tiolation of act, misdemeanor

Vocation, Commissioners shall have no other _. . . 2.

Tote of Commission entered of pewnll

Vompliel's:

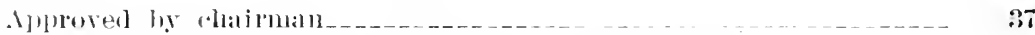

False, by shiprel to ohtain refumb etr...

War, meference to military triaftic

Was lington agent :

Carrier shall dexignate_............ 49

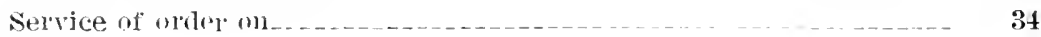

Water line:

Common entrol, ate.. with rail line....

Intelehallag of trithic with rail line.

Plysical connertion wilh ritil line_...

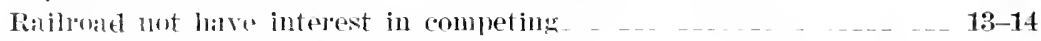

Riates to he filder with Commission, when_. 14

Ieduction in rail rates to meet completition of $\ldots \ldots \ldots \ldots$

subjer.t to ir.t, when____._._._._.

'Thromgh routo and joint rate

Transportition wholly ly w

Via l’imama (':mal _..._. 14,19

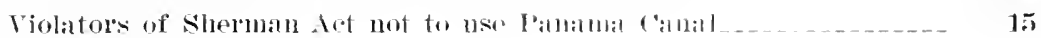

Weighing, falste:

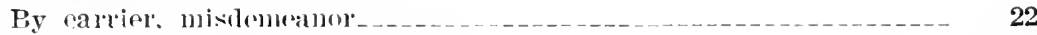

Fy shipper. frand. : mistemoamol 
Widows of carrier"s employees. bisises $10 \ldots \ldots \ldots \ldots \ldots$

Wireless cable companies__._._.

Witnesses:

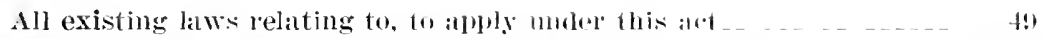

(5ommission mily require attendance of

Courts may compel attendance of _...

Courts may compel production of books.

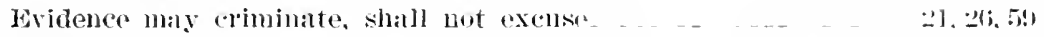

liees _......... $20: 35$

Immunity of - .5. 5.)

Immmnity of, in action for damiages....

May be sublen:led in accident investigations......

Mileage

Passes to _.

Special agents or examiners.of commision maty rammine _.

Subpenas for', block-signal investigationt _... . . . . . . . . . 101

Wrecking trains excepted, hours-of-service art_.

Wrecks, passes to persons injured in: also physirians and morses

Fards included in term "ralilroild"

Joung Men's Christian Association, thaveling secretaries of railroad. jasses to

Zones under parcel post, consent of Commission to chinge

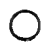









$$
\text { ijka } \frac{\text { pte }}{\text { te }}
$$


